\title{
O SENTIDO DA VIDA NO ENVELHECER: \\ o teatro espontâneo do cotidiano como um recurso em terapia ocupacional
}

\section{MARCIA PONTES MENDONÇA}

Tese de Doutorado apresentada ao Departamento de Prática de Saúde da Faculdade de Saúde Pública da Universidade de São Paulo para obtenção do grau de Doutor.

Área de concentração: Serviços de Saúde Pública

ORIENTADORA: PROFA. DRA. ALICE MOREIRA DERNTL

São Paulo

2003 
Autorizo, exclusivamente para fins acadêmicos e científicos, a reprodução total ou parcial desta tese, por processos fotocopiadores.

Assinatura:

Data:

$$
44359 / 2003 \text { doc }
$$


agradeço à Deus e

à todos os Seres de Luz,

pela vida...

Dedico este trabalho

aos meus amados filhos

Fernando, Raoni, Aruã e Theo. A quem eu ofereço meu amor incondicional.... Obrigada pelas muitas horas de compreensão em que tive que estar ausente.

aos meus pais

sem os quais eu não estaria aqui presente, especialmente à minha querida mãe, que muito me apoiou de todas as maneiras....

a todos os idosos,

que estiveram presentes nessa jornada profissional, de muita aprendizagem e de muita satisfação. 


\section{AGRADECIMENTOS ESPECIAIS}

À minha querida sempre amiga Paula:

é dificil colocar em palavras o quanto sou grata, OBRIGADA por estar sempre ao meu lado nas horas mais dificeis e também nas alegres, você é como um anjo da guarda... seja sempre feliz....

Ao meu amado Tekôlho:

Como foi bom todo o carinho e compreensão... a força ...o

amor...obrigada.

À querida amiga Camila de Assis Covas;

Muitíssimo obrigada, pela força em toda a parte prática deste trabalho acompanhando os grupos, pelo companheirismo...

À querida amiga Marcia Yumi Kano:

Muitíssimo obrigada, pela grande força ao transcrever as fitas de vídeo, ao revisar comigo este trabalho, ao ajudar nas análises, pelo companheirismo...

À querida Ana Cláudia Serra Torriceli

Pelo valioso apoio dedicado na parte prática deste trabalho.

Aos meus irmãos Júnior e Fábio,

Pelo grande apoio afetivo e material, que tornaram possivel este trabalho.

Ao Léo meu querido padastro e amigo,

Por todas as forças nesse tempo de tese, foram tantas as ajudas ...

À Alice Moreira Derntl, minha orientadora,

Pela oportunidade, sem você não teria tido tanta

determinação...obrigada...

Às minhas queridas cunhadas Fábia e Ana Sílvia, Pelo apoio, pelo carinho... 
À minha querida tia Neide e sua familia no cuidado com meu pequeno filho, quando precisei me ausentar...

Aos queridos Idelma e José, pelo apoio, pelo carinho, por existirem....

À Elissa, Maria, Nhol e Giovanni, pela força e amizade.

Ao Departamento de Terapia Ocupacional da Universidade Federal de São Carlos, às minhas colegas pelo apoio e incentivo,

Especialmente à Thelma e Léa pela revisão do texto e pelo incentivo, e às funcionárias Teka, Marta, Silvia, Cidinha e S. Aderval, pela gentileza e préstimos, sempre carinhosos....

À Faculdade de Saúde Pública, especialmente às funcionárias da CPG: Márcia, Renilda, Cidinha, Ângela, que além de serem profissionais excelentes no que fazem, o fazem muito amavelmente, obrigada pela acolhida...

ao Professor Dr José Gomes Areas pela compreensão e apoio.

Ao CNPQ pelos três anos de financiamento, que auxiliou em muito a conclusão deste trabalho.

São tantas as pessoas que caminharam comigo neste empreendimento que acredito ser dificil contemplar a todos aqui explicitamente... agradeço a todos os que colaboraram direta e indiretamente neste trabalho e que não estão aqui citados. 


\section{PRECE PARA OS QUE ESTÃO ENVELHECENDO}

Ó Senhor, tu sabes melhor do que eu que estou envelhecendo a cada dia E que um dia estarei velha.

Livra-me da tolice de achar que devo dizer algo em todas as ocasiões.

Livra-me do desejo enorme de pôr em ordem a vida dos outros.

Ensina-me a pensar sobre os outros,

A ajudar os outros,

Sem me impor sobre eles.

Apesar da enorme sabedoria que acumulei

(Seria uma pena não passá-la para os outros!),

Tu sabes, Senhor, que eu desejo preservar alguns amigos...

Livra-me da tolice de querer contar todos os detalhes

E dá-me asas para voar diretamente ao ponto que interessa.

Ensina-me a fazer silêncio sobre doenças e dores.

Elas estão aumentando e, com isso,

$A$ vontade de descrevê-las aumenta também a cada ano que passa.

Não ouso pedir o dom de ouvir com alegria as descrições das

doenças dos outros.

Ensina-me simplesmente a suportá-las com paciência.

Ensina-me a maravilhosa sabedoria de saber que possa estar errada.

Mantenha-me o mais amável possivel.

Não quero ser santa. É tão difícil conviver com os santos!

Mas um velho rabugento é a obra-prima do diabo.

Ensina-me a descobrir talentos inesperados em outras pessoas

E dá-me, Senhor, o belo dom de dizer a eles

Que descobri os seus talentos.

Teresa de Ávila (1515-1592) 


\section{RESUMO}

Mendonça MP. O sentido da vida no envelhecer: o teatro espontâneo do cotidiano como um recurso em terapia ocupacional. São Paulo; 2003. [Tese de Doutorado-Faculdade de Saúde Pública da Universidade de São Paulo].

Descritores: Envelhecimento, teatro espontâneo, terapia ocupacional, fenomenologia, saúde pública.

As ações em saúde voltadas à qualidade de vida dos idosos têm, atualmente, uma grande importância. A terapia ocupacional desempenha um papel essencial voltado ao autocuidado e à autonomia desses. Dentre o universo de atividades utilizadas pelo Terapeuta Ocupacional, destacam-se as expressivas, especificamente 0 teatro. Propõe-se um estudo qualitativo, com bases Teórico-Metodológicas de orientação Fenomenológica que tem como proposta ouvir das pessoas idosas qual o significado do envelhecer para elas. Participaram do estudo um total de 30 idosos, vinculados à Unidade Básica de Saúde Simioni, na cidade de Ribeirão Preto/SP, que faziam parte ao Programa de Aperfeiçoamento Profissional em Hipertensão Arterial e Diabetes Mellitus. A coleta de dados aconteceu em doze encontros grupais, durante um período de quatro meses, em atendimentos de terapia ocupacional, utilizando o teatro espontâneo do cotidiano como estratégia terapêutica e como um meio de acesso aos discursos expressados pelos idosos nas sessões, orientados pela questão norteadora: "Qual o significado do envelhecer para você"? A análise dos dados foi feita utilizando-se a técnica da Análise da Estrutura do Fenômeno Situado, por meio de interpretações psicológicas das unidades de significados levantadas. A partir dos discursos foi possível obter um desvelamento das várias facetas que o significado do envelhecer assume para estas pessoas e levantar aspectos que podem ser incorporados nas ações em Promoção da Saúde condizentes com as necessidades apresentadas, de acordo com uma postura fenomenológica. 


\section{SUMMARY}

Mendonça, MP. O sentido da vida no envelhecer: o teatro espontâneo do cotidiano como um recurso em terapia ocupacional. (The sense of the life in ageing: the spontaneous theater of quotidian as a resource in occupational therapy). São Paulo (BR); 2003. [Tese de Doutorado-Faculdade de Saúde Pública da Universidade de São Paulo].

Describers: Ageing, spontaneous theater, occupational therapy, phenomenology, public health.

Actions in health care related to quality of life of aged people have, currently, a great importance. The occupational therapy plays a directed essential role to selfcare and autonomy of these. Amongst the universe of activities used by Occupational Therapist, the expressive ones are distinguished, specifically, the theater. This study presents a qualitative procedure, with theoretical-methodological support of phenomenological orientation that has, as its proposal, to hear the aged people about the meaning of aging for them. Thirty aged persons, all linked to Professional Improving Program in Arterial Hypertension and Mellitus Diabetes of "Simioni" Basic Health Unit, located in the city of Ribeirão Preto-SP, have participated of this research. The data was collected in twelve group meetings, during a period of four months, in course of occupational therapy attending, using spontaneous theater of quotidian as the therapeutics strategy and as an approach to the discuss expressed by the aged ones in sessions, guided by the guiding issue: What is the meaning of getting old for you? Analysis of the data was made using the technique of the Analysis of the Structure of the Situated Phenomenon, by means of psychological interpretations the raised units of meanings. From the discuss it was possible to understand several facets that the meaning of getting old assumes for those persons and it was possible, as well, to raise aspects that could be incorporated in actions of Health Promotion Programs that were suitable to the presented necessities, in accordance with a phenomenological attitude. 


\section{ÍNDICE}

\section{Capítulo 1}

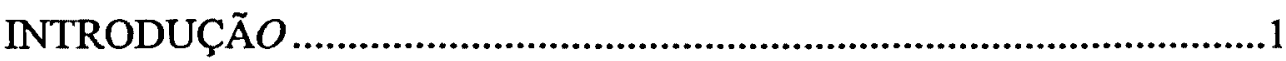

\section{Capítulo 2}

CONCEITOS E TEORIAS DO ENVELHECIMENTO .........................11

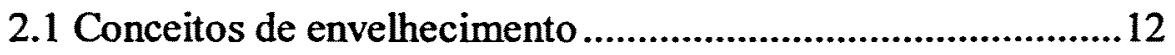

2.2 A gerontologia e a geriatria ................................................ 17

2.3 Teorias do envelhecimento................................................20

2.3.1 Teorias biológicas do envelhecimento.............................20

2.3.2 Teorias sociais e psicossociais do envelhecimento.............21

\section{Capítulo 3}

O ENVELHECIMENTO, A SAÚDE E A TERAPIA

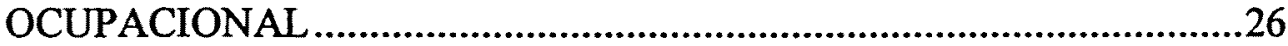

3.1 Relação entre envelhecimento, saúde e doença.......................27

3.2 Promoção da saúde e envelhecimento .................................28

3.3 Terapia Ocupacional e a saúde do idoso .............................31

\section{Capítulo 4}

O TEATRO ESPONTÂNEO DO COTIDIANO ENQUANTO UMA ESTRATÉGIA TERAPÊUTICA......................................................34

4.1 Bases teóricas e práticas do teatro espontâneo do cotidiano

4.1.1 principais autores inspiradores do teatro

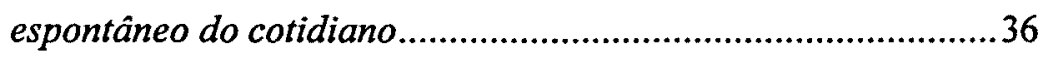

4.1.2 principais recursos utilizados no teatro espontâneo do cotidiano

\section{Capitulo 5}

A CONDUÇÃO METODOLÓGICA DA PESQUISA ...........................46

5.1 Direcionamento teórico metodológico ................................47

5.2 Como caminhou este estudo .............................................52

$5.2 .1 \mathrm{O}$ grupo e os encontros..................................................52

5.2.2 A orientação metodológica...............................................65 


\section{Capítulo 6}

BUSCANDO O SIGNIFICADO DO ENVELHECER …….........................68

6.1 As unidades temáticas - relatando os encontros......................71

6.1.1 O envelhecer estando relacionado às transformações

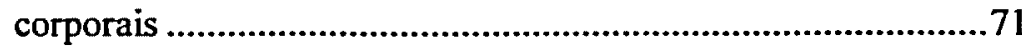

6.1.2 O envelhecer sendo um processo natural do ciclo da vida .75

6.1.3 O envelhecer em um tempo cronológico. .77

6.1.4 A velhice estando relacionada com perdas, doenças, angústia, preocupações 78

6.1.5 Assumindo ou não a velhice e a morte. .81

6.1.6 O envelhecer enquanto renovação, libertação, possibilidades.

6.1.7 $\mathrm{O}$ envelhecer estando em atividade grupal, divertindo-se, tendo planos futuros e cuidando-se .85

6.1.8 O envelhecer de si e o envelhecer do outro .88

6.1.9 O envelhecer e a importância da familia e da sociedade .90

6.1.10 Ambigüidades e contradições em relação a ser e sentir-se envelhecendo. .93

6.2 O Significado do envelhecer para as idosas 95

6.3 Vivenciando o teatro espontâneo do cotidiano .97

\section{Capítulo 7}

CONSIDERAÇOES SOBRE O ESTUDO

\section{Capítulo 8}

UMA REFLEXÃO CRÍTICA DESSA TRAJETÓRIA

\section{Capítulo 9}

REFERÊNCIAS BIBLIOGRÁFICAS

\section{ANEXOS}

Anexo 1 - Descrição dos encontros..............................................A-1

Anexo 2 - Carta convite .........................................................8-80

- Termo de consentimento livre e esclarecido.....................A-81 


\section{Capitulo 1}

\section{INTRODUÇÃO}

"A todo instante sinto que há vários, senão muitos outros em mim, se bem que nenhum deles seja o outro que costuma dizer coisas repetidas por outros.

Também não ignoro que outros me acham o outro, que em qualquer lugar, situação ou momento sou sempre o outro dos outros, e o serei sempre, inapelavelmente".

(Carlos Drumond de Andrade: De noticias \& não notícias faz-se a crônica - Rio de Janeiro, 1974) 


\section{Capítulo 1}

\section{INTRODUÇÃO}

Quando eu tinha por volta de dez anos, no início dos anos setenta, recordo de uma conversa interessante, que gerou muitas discussões com meus amiguinhos da época: falávamos sobre nossos futuros, sobre o que seríamos quando crescêssemos, mas, o que mais nos intrigava e interessava era conversarmos sobre a passagem do milênio... Ano $2000 \ldots$ Afinal, o mundo iria acabar realmente? Essa era a nossa pergunta, mas nos consolávamos: "Tudo bem se o mundo acabar, até lá estaremos bem velhos, e isso não irá importar... Eu terei 39 anos!", pronunciei... E foi a partir desse momento que comecei a pensar conscientemente na minha própria existêneia, como velhice e finitude.

Anos se passaram e a fluidez ágil e ininterrupta da adolescência não me trouxe mais reflexões acerca da minba própria velhice, preferia estar perto de crianças e jovens como eu.

A minha escolha, quanto ao rumo profissional a seguir, foi a de cursar a graduação em terapia ocupacional para trabalhar com crianças. No decorrer desta graduação descobri muitas outras facetas dessa profissão, muito mais interessantes do que eu imaginava. A humanidade, como referencial teórico que move e estrutura sua prática, tornou-se o eixo de minha atuação (pois a terapia ocupacional enquanto corpo de conhecimento integra as ciências naturais, como a anatomia, a fisiologia, a patologia e também as humanas, como a antropologia da saúde, a psicologia do desenvolvimento, entre outras). Foi durante a formação profissional que entrei em contato, pela primeira vez, com idosos em uma situação terapêutica ou de ajuda.

Cursei especialização em gerontologia na Universidade Federal de Santa Catarina e a partir de então, defini meu campo de atuação desenvolvendo uma prática personalizada de atenção em terapia ocupacional geronto-geriátrica.

Nesse mesmo periodo, iniciei minha carreira docente no Departamento de Terapia Ocupacional da Universidade Federal de São Carlos (UFSCar).

Dentre as atividades desenvolvidas na UFSCar destaco o trabalho de extensão universitária, vinculado ao ensino e à pesquisa, voltado para o atendimento em terapia ocupacional direcionado ao idoso da comunidade sancarlense, envolvendo os alunos de graduação da Universidade. Incluidas nesse projeto estão a atenção asilar 
(nas instituições que abrigam idosos da cidade), a atenção domiciliar (aos idosos dependentes e/ou necessitados deste tipo de atenção) e a ambulatorial, desenvolvida na Unidade Especial Núcleo de Atenção e Pesquisa em Saúde (UENAPES), ligada ao Departamento de Terapia Ocupacional da Universidade Federal de São Carlos. *

Foi a partir dessas experiências que fui compreendendo um pouco mais a respeito das "reais necessidades" daqueles que estão no processo de envelhecer.

Desenvolvi nesses anos de prática profissional, uma estratégia de trabalho em Terapia Ocupacional onde utilizo o teatro enquanto um recurso, que foi sendo construído conjuntamente com aqueles idosos, a partir de suas afinidades pessoais, 0 que denominei: Teatro Espontâneo do Cotidiano. Este recurso compõe-se de uma estratégia terapêutica baseado no Método Boal de Teatro e Terapia, em técnicas Psicodramatistas, Psicomotricidade, Jogos Dramáticos e bases teórico-práticas da Terapia Ocupacional, tema que discorrerei detalhadamente no decorrer deste estudo.

Essa forma de teatro proporciona um canal de expressão de maneira lúdica, a respeito da experiência vivenciada no mundo real, por permitir uma re-vivência dessa realidade individual e coletiva trazendo à tona o próprio cotidiano.

Neste sentido, a definição de BOAL (1996) sobre o teatro, afinou-se com minha maneira de concebê-lo na prática terapêutica:

"O teatro nasce quando o ser humano descobre que pode observar-se a si mesmo: ver-se em ação. Descobre que pode ver-se no ato de ver - ver-se em situacão. Ao ver-se, percebe o que é, descobre o que não é, e imagina o que pode vir a ser. Percebe onde está, descobre onde não está e imagina onde pode ir" (p.27).

Como fruto desse trabalho expressivo, um dos grupos assistidos resolveu realizar montagem e apresentação de uma peça teatral que tratasse das vivências cotidianas de cada integrante, em decorrência dos constantes questionamentos sobre

\footnotetext{
- Os procedimentos de atenção ambulatorial e domiciliar envolvem a triagem de uma demanda proveniente do Município de São Carlos e Região, que busca o tratamento em terapia ocupacional, através de encaminhamentos de profissionais, de modo espontâneo ou através de outras motivações informais (vizinhos, amigos, meios de comunicação de massa, entre outros). A partir da triagem, os idosos são avaliados em Terapia Ocupacional (avaliação fisica, psico-emocional, social e cognitiva) e orientados a participarem das diferentes formas de tratamentos oferecidos, cuja principal proposta consiste em abordar os aspectos preventivos em saúde relativos ao processo do envelhecimento, além da busca de uma conscientização das limitações e potencialidades de cada idoso, levando-se em consideração a necessidade de uma atuação contextualizada à cultura dos mesmos e, quando necessário são encaminhados a outras áreas de atenção em saúde.
} 
preconceitos defrontados pelos idosos em suas relações sociais e do pouco-caso das "autoridades governamentais" referidas pelos mesmos. Assim, através de encenações de fatos do cotidiano iniciamos uma série de "vivências" relacionadas a estes, a "peça" foi se construindo, a idéia de uma apresentação pública foi amadurecendo até culminar na sua concretização.

Nos encontros grupais o trabalho envolveu atividades que favoreceram a interação do grupo, a expressão e a impressão corporal e vocal, relaxamentos, exercícios de conscientização corporal e criatividade, propiciando um espaço para que os integrantes falassem sobre as dificuldades enfrentadas socialmente em função de sua condição etária, situações estas que se integraram no texto da peça em construção. Aspectos como a memória também foram bastante estimulados no ato de decorar textos e falas, pois construímos o roteiro da peça com uma estruturação, composta das próprias situações surgidas nos encontros de Terapia Ocupacional e nas falas que eles traziam de casa. Os idosos do grupo também buscaram atualização através de leituras e discussões de assuntos polêmicos relacionados à velhice, aspectos que não vinham sendo praticados.

Esta modalidade de teatro permitiu, entre outras coisas, que se evidenciassem as concepções que a sociedade traz embutida em todas as suas atitudes com relação às pessoas idosas. Essa experiência foi bastante significativa para todos os envolvidos e apresentou-se bastante enriquecedora para o grupo.

Encontrei no Teatro Espontâneo do Cotidiano um canal terapêutico e de expressão riquissimo. Por ser um veículo de comunicação social genuíno, farto e diversificado, proporcionou o treino de habilidades multidimensionais, evoluções na qualidade de vida e no autocuidado daqueles que o vivenciaram, de acordo com seus próprios depoimentos.

A vivência grupal facilitou a interação de cada um em seu contexto social, onde puderam aprender, participar e mesmo ensinar, possibilitando a retomada de seu espaço social, a observação do outro e a troca de experiências. De acordo com LIMA e PASETCHNY (1998):

"As atividades com grupos de terceira idade são consideradas como formas de intervenção para manter/alcançar uma vida saudável e integrada socialmente, 
propiciando aos participantes uma melhor qualidade de vida, ajudando-os a se conservarem sadios, independentes e ativos socialmente" (p.37).

Além de desenvolver uma "estratégia de atenção ao idoso" voltada para a busca de resolução dos problemas apresentados pelos próprios idosos e para a educação em saúde com enfoque no autocuidado, sentia a necessidade de buscar o significado do envelhecer para aqueles que envelhecem.

Ao obter um acesso às questões subjetivas pode-se compreender $\mathrm{e}$ empreender uma atenção em saúde na sua concepção mais ampla. Os conceitos e teorias gerontológicas que explicam a velhice, foram insuficientes para chegar a essa compreensão, pois no meu contato com cada idoso percebia uma heterogeneidade que me intrigava.

Tomei como prática constante lançar indagações às pessoas idosas dos grupos, aos alunos das disciplinas que eu ministrava e aos estagiários. Aos mais velhos eu perguntava: "O que é a velhice para você??" e aos mais novos: "Como você imagina que yai ser quando ficar velho?".

As mais variadas respostas foram oferecidas, apontando para raízes de assimilação pré-concebidas. Os de mais idade relatavam que as preocupações, as doenças e os sofrimentos faziam "envelhecer" e muitos afirmavam não se "sentirem" velhos.

Assim, busquei algumas dessas "respostas" na capacitação acadêmica profissional, quando ingressei no Curso de Pós-Graduação da Faculdade de Saúde Pública da USP-SP, ao nível de Mestrado, percorrendo um caminho de pesquisa quantitativa. $\mathrm{O}$ estudo permitiu conhecer as necessidades de saúde hospitalar da população que chega a este tipo de assistência, enfocado em suas morbidades. Pude aprender uma metodologia bastante válida para a finalidade a que se destinava.

A importância desses estudos para a Terapia Ocupacional Gerontológica centra-se no fato de que a população idosa representa uma parcela importante na demanda de serviços de saúde, utilizando com bastante intensidade os recursos destinados aos diversos níveis de atenção em Saúde Pública. Conhecendo as prevalências de suas morbidades pode-se atuar no sentido macrossocial, investindo em programas e projetos preventivos (CASELLI 1998). 
Ressaltando a importância desta pesquisa, concluí que, sendo unicamente quantitativa deixou outros questionamentos em aberto. Compreender o significado do envelhecer para as pessoas com quem convivo estava mais próximo do meu cotidiano e do meu interesse.

Em 1999 ingressei no Curso de Pós-Graduação nível de Doutorado, na mesma faculdade, no Departamento de Prática de Saúde, buscando um direcionamento da pesquisa para a área qualitativa.

Esta metodologia sugere uma compreensão mais afinada aos meus questionamentos atuais a respeito do significado do envelhecer e engloba o percurso da prática profissional na área gerontológica, desenvolvida até então.

De acordo com MINAYO (1993):

"Trazendo o debate do "qualitativo" para o campo da saude, presencia-se o eclodir de questões semelhantes às do âmbito maior das Ciências Sociais. Isso se deve ao fato, em primeiro lugar, de que a saúde não institui nem uma disciplina, nem um campo separado das outras instâncias da realidade social. (....) A sua especificidade é dada pelas inflexões sócio-econômicas, políticas e ideológicas relacionadas ao saber teórico e prático sobre saíde $e$ doença, sobre a institucionalização, a organização, administração e avaliação dos serviços e a clientela dos sistemas de saúde. Dentro desse caráter peculiar está sua abrangência multidisciplinar e estratégica. Isto é, o reconhecimento de que o campo da saúde se refere a uma realidade complexa que demanda conhecimentos distintos integrados $e$ que coloca de forma imediata o problema da intervenção. Neste sentido ele requer como essencial uma abordagem dialética que compreende para transformar e cuja teoria, desafiada pela prática, a repense permanentemente" (p.13).

De acordo com LEFÈVRE E LEFÈVRE (2003), quando se quer conhecer o pensamento de uma comunidade sobre um tema, é preciso realizar uma pesquisa qualitativa, uma vez que essa é capaz de recuperar e resgatar os pensamentos, "na qualidade de expressão da subjetividade humana", contidos na consciência humana.

Assim, minha inquietação assumiu uma proporção maior: "De que velhice estou falando? Quem é este velho? Será que esse, que eu identifico como velho e a 
sociedade determina ser velho, sente-se velho?". Cheguei assim, a uma dimensão mais subjetiva da minha indagação: "Qual o significado do envelhecer para quem envelhece?".

O contato com a abordagem fenomenológica no doutoramento despertou-me a utilizá-la como orientação metodológica onde faço uso do teatro espontâneo como recurso em Terapia Ocupacional e ao acesso aos idosos. Sendo assim, o teatro espontâneo quando inserido em programas de saúde (educativos ou outros) pode ser um instrumento importante na Promoção da Saúde.

As definições a respeito da fenomenologia, do seu método de investigação e sua aplicação na área da saúde foram ao encontro das necessidades que procurava até o momento mostrando-se bastante coerentes com aquilo que eu buscava pesquisar.

De acordo com MINAYO (1993), a fenomenologia é uma das abordagens qualitativas que tem tido grande relevância na área da saúde, uma vez que as análises fundamentadas em seus pressupostos têm desvendado as concep̧̧ões de saúdedoença como culturalmente específicas, acrescentando:

“(....) proposições da política de atenção primária, de autocuidado, revalorização da medicina tradicional e de certos grupos de investigação/ação e de pesquisa participante convergem influências fenomenológicas" (p.16).

CAPALBO (1994) coloca que interessa ao método fenomenológico a compreensão das significações essenciais e não os fatos ou suas causas, objetos da ciência natural.

A mesma autora refere em outro texto:

"A fenomenologia terá a preocupação em mostrar, e não demonstrar, em explicitar as estruturas em que a experiência se verifica, em deixar transparecer na descrição da experiência as suas estruturas universais... Ela se ocupa de fenômenos... Os seus fenômenos são os vividos da consciência, os atos e os correlatos dessa consciência"(CAPALBO 1996, p.18). 
ADORNO e CASTRO (1994) destacam que a questão da saúde pode ser tratada, entre outras abordagens qualitativas, na direção sinalizada por uma postura existencial, a fenomenológica, pelo fato desta valorizar a relação entre saúdeindivíduo como uma questão de natureza singular:

"a forma como os individuos vivem a sua doença, a forma como vivem - sem pleonasmos - sua vida e sua morte. Essa postura ganha contornos e interesse na esfera da saúde contemporânea..." (p.174).

Neste sentido, a fenomenologia mostra-se como uma abordagem metodológica que vai ao encontro da minha prática onde utilizo o teatro espontâneo como instrumento para essa compreensão.

De acordo com CAPALBO (1996), a fenomenologia adota um relativismo de perspectivas, na tentativa de compreender a realidade e a verdade. Estas estarão sempre dependentes da posição e da situação em que se está inserido, distinguindose em cada indivíduo o que pertence ao caráter da generalidade e que se repete em indivíduos diversos, apontando também aquilo que é singular no indivíduo e não pode ser sujeitado a generalizações que conduzem à leis ou a regularidades objetivas.

Para MINAYO (1993) a fenomenologia é considerada a Sociologia da Vida Cotidiana, no campo das Ciências Sociais.

Através da sua afinidade com o cotidiano e sendo despertado a partir deste, o teatro espontâneo apresenta-se como uma das formas possíveis de se buscar do próprio idoso qual o significado da vida para ele. A dramatização de situações de seu cotidiano em sua singularidade e a dramatização de um personagem, seu-semelhante, faz emergir as pluralidades inerentes a esse ser-no-mundo. A encenação do cotidiano re-vivido no teatro espontâneo possibilita que as falas e as expressões corporais revelem de uma maneira espontânea, sem reservas ou censuras sociais, os significados atribuídos por ele a respeito de sua própria vida e os que são impostos pelas convenções sociais.

Ao realizar o levantamento bibliográfico acerca de trabalhos de metodologia fenomenológica não encontrei nenhum específico que aborde o significado do envelhecer utilizando o teatro enquanto um meio. Portanto dada a originalidade do 
tema, justificou-se a busca pela compreensão desses conhecimentos na construção dessa pesquisa.

É bastante claro que não tendo um embasamento filosófico depararia com muitas dificuldades e limitações para desenvolver este estudo. O método fenomenológico e as suas variadas aplicações na área da saúde, principalmente na psicologia humanista e psiquiatria, que "emprestam" suas teorias à Terapia Ocupacional, mostrou-se como uma possibilidade. Encontrei na atitude fenomenológica, as bases para minha prática profissional, encontrando um caminho na busca de esclarecimento às minhas indagações.

Entretanto, assumo que este estudo terá muitas limitações e pretende ser um trabalho inicial sobre uma questão importantíssima para a humanidade que é seu próprio envelhecer, partindo de uma perspectiva subjetiva e de um instrumento bastante familiar a essa mesma humanidade: o teatro.

Assim, o objetivo deste estudo é trazer à luz o significado da vida para aquele que envelhece, utilizando a questão norteadora: "Qual o significado do emvelhecer para você?" e o Teatro Espontâneo do Cotidiano como um recurso auxiliar. Orientando minha pesquisa para uma compreensão existencial deste significado, pretendo estar mais perto das suas reais necessidades e poder oferecer uma atenção mais apropriada e mais realística a este ser que se mostra.

Desse desvelamento busco repensar ações em Promoção da Saúde, tendo como base o referencial da Terapia Ocupacional.

Ao compor este estudo, busquei inicialmente inúmeras referências bibliográficas, explicações teóricas a respeito do que se escreveu e se pesquisou sobre o envelhecimento, a velhice e a gerontologia.

Os constructos que compõem a gerontologia e a geriatria permitem uma elucidação do percurso que a ciência vem fazendo no intuito de compreender as questões do envelhecimento. Propondo assim, ações que busquem prevenir, tratar ou reabilitar aqueles que envelhecem de forma a prolongar o tempo de vida, acrescentando qualidade de vida a esses anos e ainda, tentando sublinhar e resolver questões macrossociais que são conseqüências do aumento e envelhecimento populacional. 
Esses conhecimentos contribuíram para a compreensão de alguns aspectos e em parte para questioná-los enquanto fonte única e fidedigna de conhecer o que significa o envelhecer.

Sendo assim, busquei compor este trabalho introduzindo, pelo presente capítulo, a relevância do tema, como ele esteve presente no meu caminhar profissional e no meu pré-reflexivo.

No capitulo 2 - Conceitos e teorias sobre o envelhecimento - serão apresentados os principais conceitos e teorias do envelhecimento presentes na literatura sob a perspectiva da geriatria e da gerontologia que situam como a questão do envelhecimento tem sido estudada ultimamente.

No capitulo 3 - O envelhecimento, a Saúde e a Terapia Ocupacional apresento brevemente como os construtos do envelhecimento se relacionam no contexto da saúde, especificamente da Promoção da Saúde e a atuação da Terapia Ocupacional enquanto um corpo de conhecimento e prática na área gerontológica que fundamentou minha formação .

No capitulo 4 - O teatro espontâneo do cotidiano enquanto uma estratégia terapêutica - abordo essa estratégia enquanto um recurso terapêutico, destacando sua importância e os principais elementos que a compõem.

No capítulo 5 - Condução metodológica da pesquisa - apresento a condução metodológica da pesquisa, introduzindo o referencial teórico fenomenológico que apoia este trabalho e descrevo como ocorreu a implantação do teatro espontâneg junto ao grupo estudado.

No capítulo 6 - Buscando o significado do envelhecer - faço um estudo atentivo dos discursos das pessoas do grupo estudado de acordo com as percepções que essas apresentaram acerca do significado do envelhecer, agrupadas em unidades temáticas utilizando como eíxo a Análise Qualitativa do Fenômeno Situado, de orientação fenomenológica e discussões a respeito das vivências teatrais.

No capítulo 7 - Considerações finais - apresento as considerações sobre 9 estudo, incluindo as reflexões acerca do significado do envelhecer e como essa compreensão pode ser utilizada na Promoção da Saúde, enquanto possibilidade de ações condizentes com a realidade subjetiva daqueles que vivenciam a velhice. 
No capítulo 8-Reflexão crítica - faço uma reflexão crítica a respeito do mey próprio caminho percorrido nesta pesquisa.

Os relatos dos encontros estão apresentados na forma de anexos, transcritos integralmente e trazem uma riqueza de diálogos e informações in natura. 


\title{
Capitulo 2
}

\section{CONCEITOS E TEORIAS DO ENVELHECIMENTO}

\begin{abstract}
"É o outro que nos diz que nossa existência tem um sentido. $\hat{E}$ ele quem certificará, depois de nossa morte, que é verdade, é real que nós existimos, que nossa vida desenrolou-se de tal ou tal maneira. Ele será o herdeiro de nosso pensamento, a memória de nossa memória. Ele testemunhará como nós éramos bonitos, jovens, como. engordamos, perdemos os cabelos, tivemos diabete ou escrevemos poemas. Sobretudo, ele nos restabelecerá na dimensão do tempo como o desenrolar da história a reconstitui no presente. Recebemos de nossos pais para dar a nossos filhos. A velhice torna-se assim uma passagem entre gerações. Ela tem uma missão. Ela não é apenas sofrida. Ela participa de todo gênero humano na longa cadeia da vida. O outro escuta, depois, fala. Ele nos fala assim como nós lhe falamos. Então, não estamos aqui apenas para a reprodução. Somos criadores de história, logo, de sentido. O nascimento da velhice é a entrada na idade em que a transmissão pode se realizar."
\end{abstract}

(CLAUDE OLIVENSTEIN in "O nascimento da velhice". EDUSC, 2001, p.51) 


\section{Capitulo 2}

\section{CONCEITOS E TEORIAS DO ENVELHECIMENTO}

\subsection{Conceitos de envelhecimento}

O envelhecimento é um processo natural inerente a todo ser vivo. A velhice é uma etapa do ciclo de vida resultante deste processo.

De acordo com BEAUVIOR (1976), a velhice humana é:

"um fenômeno biológico, que acarreta conseqüencias psicológicas típicas da idade avançada e que tem uma dimensão existencial de modificação da relação do homem no tempo, sendo todos esses aspectos interdependentes" (p.13).

De acordo com SALGADO (1980):

"a velhice é o último tempo natural do processo de vida, na qual em decorrência da alta idade cronológica, ocorrem modificações de ordem biopsicossocial que afetam a relação do individuo com o meio" (p.25).

Para CARVALHO FILHO e PAPALÉO NETTO(1994), o envelhecimento pode ser conceituado como:

"um processo dinâmico e progressivo onde há modificações tanto morfológicas como funcionais, bioquímicas $e$ psicológicas que determinam progressiva perda da capacidade de adaptação do individuo ao meio ambiente, ocasionando maior vulnerabilidade e maior incidência de processos patológicos que terminam por levá-lo à morte" (p.1).

MORAGAS (1997) aponta para três concepções de velhice, que compreendem: 
"a velhice cronológica, baseada nas idades tradicionais de afastamento do trabalho; a velhice funcional, que reflete a relação tradicional de velhice $e$ limitações; e a velhice enquanto etapa vital, baseada no reconhecimento de que o transcurso do tempo produz efeitos na pessoa, limitada unicamente por condições objetivas externas e subjetivas" (p.17).

Para OLIEVENSTEIN (2001), "a velhice é uma viagem de duas faces, uma da solidão, infinitamente mais dolorosa do que a outra, que é a da relação com os outros"'(p.18).

Para ALVES (2002) a velhice pode ser "o tempo da sabedoria" (p.78).

Existem muitas concepções sobre a velhice. Vários são os aspectos envolvidos e condicionantes do processo de envelhecer: a cultura, a dimensão psicológica, biológica, social, econômica, ideológica e política. $\mathrm{O}$ velho é definido em cada sociedade pelo acúmulo de anos, seu desempenho e aparência física, seus papéis sociais, sua relação com o trabalho e outras funções. Cada uma dessas áreas de conhecimento permite uma resposta parcial sobre o significado da velhice.

RODRIGUES et al. (2000), coloca que o "caráter biológico, evidenciado pelas mudanças na imagem corporal, juntamente com o aparecimento das dificuldades de ordem fisica e alterações na memória, apresentam-se como sinais de velhice para os idosos" (p.16).

Conceituações sobre velhice encontradas na literatura apresentam-se relacionadas com uma idéia de tempo de vida, em que se toma como base a expectativa média de vida da população. Assim todos que se aproximam da idade estabelecida como limite médio são velhos, mesmo que não se sintam velhos.

Segundo a Organização Mundial de Saúde, a velhice convencionalmente inicia-se aos 65 anos de idade. Nos países do Terceiro Mundo este ponto de corte tem sido 60 anos (VERAS 1995).

De acordo com MORAGAS (1997), os 65 anos constituem, em muitos países, principalmente os considerados países desenvolvidos, a fronteira da aposentadoria, em virtude de uma política social de proteção à velhice. $\mathrm{O}$ mesmo autor coloca que essa mesma política hoje infringe os direitos essenciais da pessoa que aos 65 anos poderia desempenhar, perfeitamente, um trabalho. 
Verifica-se que o envelhecimento está associado à idade cronológica, sendo a velhice demarcada em cada sociedade por ela.

A relação entre tempo e envelhecimento é evidente. Pesquisadores como SCHROOTS (1996) definiram diferentes conceitos de tempo e suas relações com o envelhecimento: o tempo fisico, objetivo, mensurável, que pode ser relacionado à idade do organismo; o tempo biológico, individual, que reflete as variações entre individuos de igual idade cronológica definindo a posição do indivíduo frente a sua expectativa de vida e o tempo universal, que seria a experiência subjetiva do tempo.

Complementam JÚNIOR e NETO (1992) que no idoso há uma vivência interna de lentificação da passagem do tempo, enquanto o tempo externo parece acelerado.

Por outro lado, alguns autores acrescentam outra visão sobre o processo do envelhecimento, onde o fator tempo-idade aparece como um coadjuvante e não com causa do envelhecimento. De acordo com BOTH (2000), todas as alterações típicas do envelhecimento como: privações sensoriais, alterações da motriçidade, fragilização orgânica e doenças, estão condicionadas aos hábitos anteriores e às disposições hereditárias. Assim, as conquistas biomédicas apontam para os costumes como problematizadores de quantidade e qualidade de vida e para a possibilidade da idade ser também um resultado e não uma direção com marcas essenciais.

A partir desse entendimento há a idéia do indivíduo não ficar velho muito tempo, mas levar mais tempo para envelhecer e apesar da presença de fragilidades, encontrar opções para a manutenção de sua integridade (op.cit.).

O mesmo autor criticando as classificações etárias, coloca:

"O evento da aposentadoria, a realidade familiar, as oportunidades de ocupação de papéis, as mediações culturais pregressas, a previdência e providência de recursos financeiros, a disposição de recursos na área da saúde podem ser decisivos no advento da velhice. (...) Os reducionismos conceituais sobre as faixas etárias constituem-se em regimes disciplinares perversos e, em razão disso, alguns sinais de envelhecimento levam os sujeitos a se afastarem do desenvolvimento" (op.cit., p.35). 
Na mesma direção, MORAGAS (1997) coloca que a definição da velhice através da idade cronológica permite uma concepção individualizada da pessoa idosa. Atualmente consideram-se outras características pessoais, familiares e sociais.

DEBERT (1999) citando um trabalho do antropólogo Meyer Fortes (1984), coloca que as idades cronológicas, baseadas num sistema de datação, estão ausentes na maioria das sociedades não-ocidentais, ao passo que nas sociedades ocidentais são um mecanismo básico de atribuição de status (maioridade legal), de definição de papéis ocupacionais (entrada no mercado de trabalho) e de formulação de demandas sociais (direito à aposentadoria).

$\mathrm{Na}$ sociedade ocidental, complementa a autora, a idade cronológica é estabelecida por um aparato cultural, independente e neutro em relação à estrutura biológica e à incorporação dos estágios de maturidade, imposta por exigências de leis determinantes de direitos e deveres do cidadão. Deste modo, a idade cronológica só tem relevância quando o quadro político-jurídico ganha precedência sobre as relações familiares e de parentesco para determinar a cidadania.

Sendo assim, o processo de agrupar pessoas em função de sua geração é totalmente distinto do de agrupar pessoas em função de seu estágio de maturidade $\mathrm{e}$ de sua idade cronológica (op.cit. p.46).

Continuando nesta yisão, a mesma autora, considerando outros estudos, coloca que a idéia de gerações:

"implica em um conjunto de mudanças que impõe singularidades a determinadas gerações pelos seus costumes e comportamentos, a exemplo da geração do pós-guerra, da televisão, de 68. A geração é menos marcada pela idade das pessoas que a compartilham do que pela vivência de determinados eventos que marcam trajetórias passadas e futuras" (op.cit., p.52). 
$\mathrm{Na}$ modernidade, as conexões entre vida pessoal e troca entre gerações se quebram, ao passo que na pré-modernidade a tradição e a continuidade estavam estreitamente vinculadas com as gerações. $\mathrm{O}$ curso da vida* torna-se um espaço de experiências abertas e não de passagens ritualizadas de uma etapa para outra (op.cit.).

A representação social e a construção cultural relativa à velhice apresentam uma série de características que exprimem valores e preconceitos em relação a esta condição, pois o envelhecimento populacional ainda é um fenômeno inédito no Brasil, ocorrendo em uma sociedade não preparada para tal e estruturada para uma população jovem.

Neste sentido BOTH (2000) afirma:

“ $O$ envelhecimento das populações é um fato recente, de forma que os mais velhos e aqueles que envelhecem ainda estão surpresos com a condição humana dada pela velhice" (p.102).

Através da história humana, nota-se que a velhice assume diferentes posições e atribuições em diversas sociedades e épocas.

A busca da fonte da juventude, o pavor da velhice como sinônimo de doença e algo esteticamente indesejável são aspectos que acompanham o homem ao longo da história. O despreparo em relação a esta fase da vida gera tabus e preconceitos expressados pelos jovens e pelos próprios idosos. Frases como: "velho não deve saber de certas coisas, não namora, não aprende, lugar de velho é no asilo, velho é criança", são proferidas e aceitas por idosos e não-idosos, embora digam respeito a opiniões formuladas em geral, por pessoas não idosas.

Neste sentido, BEAUVIOR (1976) refere que:

"o destino dos velhos é decidido pela coletividade de acordo com os interesses e as possibilidades da mesma, o sentido atribuido pelos homens à sua própria existência é o que define o sentido e o valor da velhice" (p.97).

\footnotetext{
* Há distinções no conceito de curso de vida: a primeira refere-se ao curso de vida moderno "ancorado na primazia da produtividade econômica e na subordinação do individuo aos requisitos racionalizadores da ordem social" e a segunda refere-se ao curso de vida pós-moderno que surge para "dar conta das mudanças que caracterizam a experiência contemporânea, levando a uma relativização das normas de cada estágio da vida, indicando a emergência de uma sociedade em que a idade passa a ser imelevante"(DEBERT 1999, p.56).
} 
Segundo MAGALHÃES (1989), há uma inevitável exterioridade nas observações que os mais jovens fazem sobre os mais velhos, exceto quando o velho é objeto descritivo de pesquisa. Quando se trata de perceber o significado da velhice, a relação predominante ao observador adulto é a sua condição e o seu olhar de adulto. Não se pode penetrar na interioridade dos sentimentos dos velhos em relação à vida, ao seu próprio corpo, à sociedade $\mathrm{e}$ às transformações culturais que todos vivem. $\mathrm{O}$ não-velho observa de fora e é o que este sente e pensa que transforma em imagens do envelhecimento.

Confirmando esta visão MORAGAS (1997) acrescenta:

"A rotulagem estética negativa dos idosos constitui um processo semelhante ao que experimentaram outro grupos 'diferentes'. Os deficientes fisicos ou os negros, no Ocidente, por exemplo, também se viram marginalizados porque não se encaixavam no ideal estético promovido pela sociedade de massas. A rejeição que boa parte da população experimenta diante de um idoso cujo corpo revela a marca dos anos constitui uma resposta aprendida mediante a pressão social que insiste nos valores juvenis e força a aceitar como padrão de beleza o que caracteriza somente uma pequena parte dos cidadãos"(p.45).

\subsection{A gerontologia e a geriatria}

Os estudos que contemplam a questão do envelhecimento devem fazer referências aos conceitos de gerontologia e geriatria.

A gerontologia pode ser conceituada como: "o estudo cientifico do processo do envelhecimento", conceito criado por Élie Metchnikoff em 1903 (RODRIGUES et al. 2000, p.16).

Outro conceito, de Caillet et al. (1981), citado por FRANÇA e SOARES (1997) mais atual e completo a define como:

"o estudo dos fenômenos do envelhecimento em seus diversos aspectos 
(demográficos, econômicos, psicológicos e sociais), e se interessa sobretudo pelas mudanças de condições, de status e de atitudes que intervém com a idade e os meios disponiveis para facilitar a inserção da pessoa idosa no sistema social normal" (p. 143).

De acordo com DEBERT (1999), foi a partir dos anos trinta do século passado que a reflexão sobre a velhice, como problema social, passou a ocupar um espaço maior em disciplinas como a sociologia e a psicologia. Este interesse levou à criação da gerontologia como um campo interdisciplinar de estudos e pesquisas sobre o envelhecimento e a velhice.

Segundo RODRIGUES et al., $(2000$, p.16) a geriatria foi conceituada primeiramente por Ignaz L. Nascher, em 1909, como a "área que trata especificamente dos problemas médicos dos idosos" e só se constituiu como uma disciplina em meados do século vinte, embora a medicina sempre procurasse explicar as causas do envelhecimento e encontrar meios de retardar seus efeitos.

DEBERT (1999, p.196) coloca que, segundo Benoit-Lapierre, a geriatria nasce da gerontologia e gradualmente ganha autonomia, sendo que "somente a partir dos anos 60 os problemas ligados à saúde dos velhos recebem espaço maior nas revistas médicas prestigiadas; bem como, ocorrem a criação de associações $e$ sociedades de geriatria e formações universitárias e pós-universitárias instituidas na área".

À medida que se cria a consciência de que envelhecer não representa qualquer tipo de infração e nem abuso, porque é um fato natural, estaremos percebendo a razão da necessidade de buscar formas de melhorar a vida cotidiana de milhares de pessoas.

De acordo com BOTH (2000):

"A presença significativa dos mais velhos obrigou a ver essa nova condição humana em sua singularidade, e não apenas nas atribuições relacionadas à vida adulta economicamente produtiva. De um modelo deficitário de velhice, pode-se passar, então, para um modelo de desenvolvimento do curso de vida"(p.102). 
Ainda, o mesmo autor complementa que os esforços culturais e sociais devem ter a intenção de sair do antigo discurso relativo à velhice, onde os idosos são enfocados como "coitadinhos" e "merecedores de caridade" para um discurso de vigor humano capaz de fazê-los cidadãos iguais a todos. Neste sentido, a renovação das condições sociais volta-se para a presença expressiva dos mais velhos e para a renovação do estoque de interpretações sobre o processo do envelhecimento, no sentido de "escutar o velho", pois nas circunstâncias em que o velho vive, pode-se revelar um universo de verdades que apelam para políticas preventivas e antecipadoras de ações educacionais para as gerações jovens (op. cit., p. 173).

Outro ponto a destacar, neste sentido diz respeito à importância das relações intergeracionais. De acordo com FRANÇA e SOARES (1997), os programas e pesquisas intergeracionais são fundamentais na quebra de preconceitos, no resgate da auto-estima dos idosos e na atualização de padrões e normas morais e sociais, pois proporcionam a reciclagem em relação aos novos conhecimentos. Desta maneira os idosos tornam-se participativos na sociedade. A desconstrução da segregação geracional poderá se concretizar efetivamente pela educação através do contato e convivência entre as gerações. Como realça Kingson (1987) citado por FRANÇA e SOARES (1997).

"Uma estratégia de aproximação intergeracional no sentido político é necessária para construir pontes entre muitos grupos para apoiar programas e legislações de interesse comum a todas as idades" (p.162).

Em $1^{\circ}$ de outubro de 2003, a Lei 10.741 que dispõe sobre o Estatuto do Idoso e regula os direitos assegurados às pessoas com idade igual ou superior a 60 (sessenta) anos é sancionada. Em linhas gerais, essa lei "garante ao idoso todos os direitos fundamentais inerentes à pessoa humana, sem prejuízo da proteção integral assegurando a preservação de sua saúde física e mental e seu aperfeiçoamento moral, intelectual, espiritual e social, em condições de liberdade e dignidade, delegando à família, à comunidade, à sociedade e ao Poder Público com absoluta prioridade, a efetivação do direito à vida, à saúde, à alimentação, à educação, à cultura, ao esporte, 
ao lazer, ao trabalho, à cidadania, à liberdade, à dignidade, ao respeito e à convivência familiar e comunitária"( BRASIL 2003).

FERNANDES (1997) questionando um aspecto importante relacionado à formação educacional da sociedade que lida com o idoso, frisa que o envolvimento $\mathrm{e}$ a atuação do Estado deveria estimular o funcionamento de um mercado de trabalho que absorva e se comprometa com o desenvolvimento dos técnicos formados adequadamente no campo da Gerontologia Social e da Geriatria, para atender a cerca de doze milhões de idosos.

\subsection{Teorias do envelhecimento}

Baseada em estudos de diversos autores e pesquisadores, como CARVALHO FILHO e PAPALEO NETTO (1994), JÚNIOR e NETTO (1992), LEGER (1994), SALGADO (1980), entre outros, é usual subdividir os aspectos do envelhecimento em: biológico, psicológico e social.

\subsubsection{Teorias biológicas do envelhecimento}

As teorias biológicas explicam o processo do envelhecimento fisico e mudanças no corpo. De acordo com SALGADO (1980), as ciências naturais descrevem que o envelhecimento inicia-se desde o nascimento, por um processo de mutação biológica, onde a velhice é determinada pelo desgaste físico que os anos produzem, distinguindo duas etapas: a do acréscimo que inclui a formação, fortificação e o desenvolvimento, seguido por um reduzido tempo intermediário e a do decréscimo que consta de um desgaste em menor ou maior intensidade, dependendo das condições particulares, ambientais e estruturais. $O$ mesmo autor porém, ressalta que embora essa teoria seja ainda aceita, pesquisas científicas atuais revelam que o organismo humano apresenta uma ampla capacidade de minimizar esse desgaste, controlando-se as variáveis, mas que não se pode precisar até que ponto o desgaste pode ser evitado. Graças a sua natureza biológica, o homem teria condições para viver até os cento e vinte anos, sob condições adequadas. 
De acordo com CARVALHO FILHO e ALENCAR (1994) considera-se que os mecanismos do envelhecimento estão relacionados com a capacidade de sintetizar proteínas.

É observado que os idosos, sob o ponto de vista orgânico apresentam diversas alterações: alterações celulares, teciduais, orgânicas, alterações funcionais relacionadas às estruturas morfológicas $\mathrm{e}$ às funções dos principais sistemas corporais e finalmente, alterações do mecanismo de homeostase. Todas essas alterações ocorrem diferentemente de indivíduo para individuo e estão sujeitas a fatores intrínsecos (genéticos, radicais livres, imunidade celular e humoral, ligações cruzadas e ligação DNA-histona) e a fatores extrínsecos (radiação, altitude, temperatura, poluição, alimentação e tensão emocional) (CARVALHO FILHO e ALENCAR 1994; RODRIGUES 2000).

\subsubsection{Teorias sociais e psicossociais do envelhecimento}

Em relação aos aspectos psicológicos inerentes ao processo do envelhecimento, observa-se diversas abordagens que tratam diversamente os aspectos presentes nesse processo.

Para NERI (1995), o resultado mais confiável e generalizável sobre o processo de envelhecimento é que este envolve uma diminuição gradual dos processos biológicos e psicológicos.

Complementando, JÚNIOR e NETO (1992), ressaltam que as modificações que ocorrem durante a vida são vivências e experiências individuais e não relacionadas diretamente a idades cronológicas específicas.

De acordo com RODRIGUES (2000, p.18), as teorias psicológicas enfatizam as mudanças no comportamento e papéis sociais ao longo da vida. Segundo a autora, as teorias subdividem-se em: clássicas destacando-se a "teoria da atividade" de Havighurst (1948), a "teoria do desenvolvimento da personalidade" de Erikson (1950) e a "teoria da personalidade da idade do envelhecimento"; modernas, destacando-se o "desenvolvimento da vida e envelhecimento" de Baltes et al. (1980, 1987 e 1992) e a teoria do "comportamento genético e envelhecimento" de Plomin; 
McClearn (1990) e Pedersen (1996) e as novas teorias da década de 90 como a "gerodinâmica" de Schroots (1995) e a "gerotranscendência" de Tornstam (1996).

SALGADO (1980), acrescenta que:

"Com a velhice, o equilibrio se torna (sic) mais dificil, pois a longa história da vida acentua as diferenças individuais, quer pela aquisição de um sistema de reivindicações e desejos pessoais, quer pela fixação de estratégias de comportamento. No tempo da maturidade e velhice, certas modificações se processam no intimo do individuo, de forma que ficam alterados seus valores $e$ atitudes" (p 35).

No aspecto social do envelhecimento observa-se uma grande contradição. Se por um lado a sociedade é responsável pela criação de mecanismos de segurança, proteção e tratamento, que prolonguem a vida, por outro lado, impede a participação do idoso no meio social. Este é colocado em uma situação de marginalidade social, onde encontra, além de barreiras fisicas, as sociais, com típicos comportamentos de preconceito e discriminação.

No Brasil, está ocorrendo um crescimento rápido da população idosa, devido a uma melhoria das condições materiais de vida e de recursos tecnológicos e científicos (medicina, saneamento, habitação, estilo de vida, entre outros), provocando uma alteração no quadro demográfico (VERAS 1995).

Diante do quadro social que esse fato vem gerando, a gerontologia social ciência voltada aos processos psicossociais manifestados na velhice - trouxe contribuições importantes para se compreender as diversas facetas que 0 envelhecintento tem tido socialmente.

MORAGAS (1997) descreve, a seguir, como deu-se o histórico do significado social da velhice e o início das ações na área.

Nos anos 60, Burguess define a velhice nas sociedades industrializadas através da idéia de "roless role" - a sociedade não prevê um papel específico ou uma atividade para os velhos, Barron considera-os uma minoria desprivilegiada, ou seja seu destino inevitável seria a baixa renda e o baixo status. Rose diz que os velhos 
formam uma subcultura com um estilo próprio de vida que se sobrepõe às diferenças de sexo, ocupação, religião e identidade étnica.

No final dos anos 60 , segundo este autor, surgem duas grandes teorias : a teoria da atividade que representa a mais antiga maneira de entender 0 envelhecimento humano propondo que o idoso deva estar em atividade; quanto mais ativo, mais satisfeito com a vida e a teoria do desengajamento, que explica a velhice a partir do afastamento, visto como algo universal e inevitável entre idosos e sociedade. Para ambas a velhice é definida como um momento de perdas de papéis sociais. A diferença entre ambas está na definição de como ocorre esse ajustamento em relação à essa perda e em medir o grau de conformidade e o nível de atividade dos idosos.

Nos anos 70 a Gerontologia é fundada como campo específico de estudos, baseada na hipótese de que a velhice homogeneizaria as experiências vividas ou os problemas enfrentados pelos idosos.

A partir dos ANOS 70 inicia-se um crescimento do número de pesquisas sobre a velhice, sendo que, até esta data, os estudos apontavam para o que é comum na experiência de envelhecimento nas sociedades industrializadas. A produção acadêmica foi marcada pela necessidade de olhar com mais sutileza para o conjunto de transformações ocorridas na velhice e no processo de envelhecimento ao longo do século XX.

Sob o ponto de vista da dimensão social do envelhecimento, a visão negativa que a sociedade têm dos velhos influencia diretamente a sua adaptação, uma vez que o envelhecimento transforma suas relações com o meio social (SALGADO 1980).

Dentre as "inadaptações" estão a perda do papel profissional, que é fonte de muitos desajustes para o idoso e a perda dos papéis referentes à família, devido à alteração na sua função de responsável pela família e à redução do grupo familiar.

BARO (1985) refere que a adaptação do idoso que sofre uma perda passa pelas fases de negação, ansiedade, agressão e depressão e, frequentemente, as pessoas têm dificuldades porque não a compreendem. Em casos extremos quando a depressão não é controlada, pode-se chegar ao suicídio. 
SALGADO (1980) pondera ainda que o idoso diminui gradativamente os contatos sociais com o mundo e volta-se para si, surgindo então, sentimentos de inutilidade, solidão e consciência negativa em relação à velhice.

No entanto, vale ressaltar que as modificações que ocorrem durante a vida são vivências e experiências individuais.

Atualmente, observa-se que no afastamento provocado pela velhice há um movimento mútuo, onde o homem isola-se do grupo social e este não adquire conhecimento de sua existência, sendo esse "movimento" justificado por valores e atitudes prevalecentes nas culturas e estruturas sociais.

Segundo BARO (1985), a solidão tem sido apontada na atualidade como uma questão crucial para o homem moderno, seja nos grandes centros urbanos ou no seio familiar, ela não consiste unicamente em manter pouco contato com outras pessoas, mas na qualidade do contato. Perdas de parentes e amigos, dificuldades de transportar-se, incapacidades e outras dificuldades advindas com o processo do envelhecimento podem dificultar ou impedir o contato com pessoas e trazerem, como resultado, a solidão.

A sociedade, de uma certa maneira, delega à família o papel de suporte social e econômico. Como está firmado no Estatuto do Idoso, sancionado este ano, a familia tem agora esse dever.

GONÇALVES et al. (1990), coloca a dificuldade de manutenção do idoso no meio familiar dentre aquelas famílias com poucas condições econômicas, devido a falta de outros meios alternativos de atenção ao idoso, que possibilitem sua permanência em casa contando com um apoio comunitário condizente e de respaldo a estas familias.

Isto tem sido cada vez mais freqüente devido ao aumento das pequenas famílias (nucleares) nos grandes centros, em resposta às necessidades de trabalho e transformaçōes culturais. Os idosos que tradicionalmente eram acolhidos pelas familias extensas (o que ainda ocorre em zonas rurais e cidades menores), não mais encontram este espaço nestes centros. Fatores relacionados a uma maior mobilidade das familias e a um aumento no número de separações e divórcios entre os casais também concorrem para o descompromisso familiar e o decorrente isolamento social do idoso (RAMOS et al. 1993). 
Em resposta a esta condição de vida o espaço institucional tem sido o destino de grande parte destes humanos.

A dependência também é um fator psicossocial importante a ressaltar.

De acordo com NERI (1995), a dependência, a enfermidade e o medo da morte são fatores psicossociais pertinentes à maciça maioria dos idosos. Doenças crônicas e degenerativas, a presença de dor e outras dificuldades geralmente vêm acompanhadas de medo e humilhação. O medo da morte, principalmente da iminente, no caso de doenças terminais, vem acompanhado do temor da dor e da forma como se dará a morte.

Baltes e Silverberg (1994) citados por PAVARINI (1996), classificam as principais dependências da velhice em: dependência estruturada, relacionada à participação do indivíduo no processo produtivo, que no idoso pode estar comprometida pela aposentadoria; a dependência fisica indicada como incapacidade funcional, pode tornar-se mais pronunciada na presença de doenças cerebrais degenerativas e a dependência comportamental, segundo a autora, a mais temida pelo idoso, sendo esta última socialmente induzida que é instrumental para a manutenção do controle pessoal.

Considerando as diversas formas de buscar conhecimento sobre o envelhecimento e sua representação social, é possível vislumbrar muitas tentativas de encontrar-se generalizações acerca do envelhecimento. Em parte elas respondem em parte suscitam novas perguntas. A questão é: Como chegar a compreender o envelhecimento enquanto fenômeno?

Iniciando pelo contexto das conceituações gerontológicas revelou-se que existe um longo debate a respeito, buscas de respostas e algumas generalizações bastante observáveis.

Uma vez que atuo na área da saúde, onde o envelhecimento assume dimensões diversas que necessitam ser particularmente aprofundadas, abordarei no próximo capítulo esse aspecto relacionando-o com a Promoção da Saúde e a Terapia Ocupacional. 


\title{
Capitulo 3
}

\section{O ENVELHECIMENTO, A SAÚDE E A TERAPIA OCUPACIONAL}

\author{
"(...) é assim que, agora, \\ aquele longo periodo de doença me \\ aparece: sinto como se, nele, eu \\ tivesse descoberto de novo a vida, \\ descobrindo a mim mesmo, \\ inclusive. Provei todas as coisas \\ boas, mesmo as pequenas, de uma \\ forma como os outros não as provam \\ com facilidade. E transformei, então, \\ minha vontade de saúde e de viver \\ numa filosofia".
}

Nietzsche 


\section{Capitulo 3 \\ O ENVELHECIMENTO, A SAÚDE E A TERAPIA OCUPACIONAL}

\subsection{Relação entre envelhecimento, saúde e doença}

Em um estudo descrito por NERI (1993), concluiu-se que a saúde percebida e as maneiras de lidar com problemas de saúde são preditivas do bem-estar na velhice, mais do que as condições objetivas, avaliadas segundo parâmetros médicos. A satisfação com a família, a situação econômica e psicológica, a capacidade de iniciar e manter contatos sociais também podem indicar o grau de satisfação e bem estar na velhice.

Muitas vezes, os problemas de saúde na velhice causados por patologias múltiplas, são agravados pela solidão, a pobreza e a institucionalização. Sejam quais forem as causas que levem o idoso a procurar assistência, o sistema político e social ainda não responde de maneira satisfatória às suas necessidades.

Para KALACHE et al. (1987), o destino reservado ao idoso pela sociedade ocidental contribui para o surgimento de agravos à saúde. As enfermidades crônicas na velhice requerem intervenções custosas e uso de tecnologia complexa. Sendo assim, alertam a necessidade de cuidados preventivos, pois doenças que não podem ser resolvidas do dia para a noite, que continuarão existindo por um longo período, absorvem grandes quantidades de recursos materiais e humanos. A partir de uma entrada no sistema de prestação de serviços tornando o uso dos mesmos é extraordinariamente prolongado.

A maioria da população idosa continua utilizando os serviços de saúde disponiveis e não especializados em geriatria. Buscando formas de atenção que nem sempre são resolutivas como a utilização de Serviços de Urgência e Pronto Atendimento, em detrimento de Serviços de Atenção Primária (CASELLI 1998).

Neste sentido, o enfoque que tem sido dado a essa questão, traz na Promoção da Saúde respostas mais resolutivas no que tange aos serviços de saúde voltados à população idosa. 


\subsection{Promoção da saúde e envelhecimento}

A Promoção da Saúde é definida pela Organização Mundial da Saúde (MINISTÉRIO DA SAÚDE 1996), como um processo político e social global, que abrange não somente as ações dirigidas para o fortalecimento de habilidades e capacidades dos indivíduos, mas também aquelas dirigidas para a modificação das condições sociais, ambientais e econômicas, com a finalidade de atenuar seu impacto na saúde pública e individual, sendo a participação da pessoa e de grupos de pessoas o fator fundamental do processo.

A definição da saúde, a partir desse contexto, é considerada não como um estado abstrato (ideal-utópico), mas como a capacidade de desenvolver o projeto potencial pessoal de vida e responder de forma positiva aos estímulos do mundo.

O termo "Promoção da Saúde" foi utilizado pela primeira vez por Henry E. Sigerist, historiador médico canadense, no ano de 1945, que a apontava como uma das quatro áreas essenciais da medicina.

As diversas Conferências Mundiais (Ottawa - 1986, Adelaide - 1988, Sundsvall - 1991, Santafé - 1992, Jacarta - 1997), apontam a idéia de Promoção da Saúde como um paradigma alternativo para as políticas de saúde. Este novo paradigma representa uma nova maneira de interpretar as necessidades e ações de saúde, entendida como resultante de um conjunto de fatores individuais e coletivos, sociais, econômicos, políticos, étnicos, religiosos, culturais, éticos, psicológicos, ambientais, entre muitos outros, interagindo em um processo dinâmico. A Promoção da Saúde já não pertence ao domínio exclusivo dos profissionais da saúde e requer o estabelecimento de parcerias que aliem esforços individuais e coletivos. Neste novo paradigma a maior relevância consiste na cooperação intersetorial e a participação da população, onde a educação é um dos componentes e recursos fundamentais a serem utilizados nas estratégias para a Promoção da Saúde (PEREIRA et al. 2000; MINISTÉRIO DA SAÚDE 1996).

Em todos os documentos sobre Promoção da Saúde ressalta-se a importância e a necessidade de reorientação dos serviços de saúde neste sentido, além de suas responsabilidades de prover serviços clínicos e de urgência, que sejam ao mesmo tempo, abrangentes e que respeitem as peculiaridades culturais. Isso requer um 
esforço maior de pesquisa e comunicação em saúde, mudanças na educação e no ensino de profissionais dessa área, focalizando as necessidades globais do indivíduo, havendo para isso uma participação ativa das pessoas na modificação das condições sanitárias e na maneira de viver (PEREIRA et al. 2000).

A formulação de uma política de atenção aos idosos e a organização dos serviços comunitários são um bom exemplo de Promoção da Saúde.

Em 1996, o tema do envelhecimento e saúde foi incorporado ao Programa de Saúde Familiar e População da Divisão de Proteção e Promoção da Saúde, que tem por meta desenvolver um plano de ação sobre envelhecimento, considerando os idosos como participantes ativos na sociedade e oferecendo a base para um novo enfoque na Promoção da Saúde (OPAS 1998).

O programa de Envelhecimento e Saúde da Organização Panamericana da Saúde (OPAS) empenha-se em sensibilizar os governos nacionais em relação às repercussões do envelhecimento da população sobre as políticas, desenvolver pesquisas epidemiológicas e treinar os agentes primários de saúde no atendimento dos idosos. Os estudos sobre longevidade oferecem indícios claros de que a prevenção de doenças e deficiências, a manutenção de funções físicas e cognitivas e a participação constante em atividades sociais e produtivas são fatores cruciais para um envelhecimento bem sucedido (op. cit.).

Um exame das politicas, planos e programas nacionais em favor dos idosos mostra que a maior parte da atividade legislativa envolve questões de aposentadoria e pensões para proteger as pessoas contra a pobreza extrema e proporcionar acesso à atenção de saúde.

A ausência de educação gerontológica e geriátrica para os profissionais de atenção primária e de aptidões para gestão de programas entre gerontologistas e geriatras constitui grave barreira ao desenvolvimento de planos e programas nacionais.

$O$ enfoque conceitual da OPAS baseia-se no pressuposto de que o envelhecimento bem-sucedido depende muito da prevenção de doenças $e$ deficiências, da manutenção de altas funções fisicas e cognitivas e da participação constante em atividades sociais e produtivas. Seu plano de ação apresenta um enfoque holístico da saúde e do bem-estar dos idosos que incorpora a perspectiva do 
curso de vida; da Promoção da Saúde; de gênero; intergeracional e ética, pelo desenvolvimento e fortalecimento de programas e serviços nacionais e locais (op. cit.).

Em 2002 aconteceu a II Assembléia Mundial sobre o Envelhecimento, que trouxe como tema central "uma sociedade para todas as idades". Destacando o plano de ação em três prioridades a serem implantadas mundialmente: os idosos e o processo de envelhecimento, centrada na necessidade das sociedades ajustarem suas politicas e instituições para que a crescente população idosa seja uma força produtiva em benefício da sociedade; a Promoção da Saúde e do bem-estar para todo ciclo de vida, implantando políticas que promovam desde a infância e durante o curso de vida, a boa saúde, alcançando assim uma velhice saudável; e a criação de contextos propícios e favoráveis, que promovam políticas orientadas para a família e a comunidade como base para um envelhecimento seguro, aprimorando as condições de moradia, promovendo uma visão positiva do envelhecimento e a necessidade de uma conscientização pública, de que os idosos têm importantes contribuições a dar para a sociedade (PESSINI 2002).

Portanto, no contexto da Promoção da Saúde o envelhecimento tem assumido uma nova conformação política e social, voltando-se para alternativas bastante diversificadas em termos de ações em saúde.

Em programas multiprofissionais que estimulam a formação de grupos de auto-ajuda, as ações priorizam o autocuidado e o cuidado informal. Na organização da rede de serviços, com fiscalização pelos gestores do Sistema Único de Saúde (SUS), destacam-se a criação de serviços alternativos de saúde do idoso, implantando unidades de referências com equipe multiprofissional e interdisciplinar, política de recursos humanos, estudos de pesquisa, apoio e participação em atividades técnicocientíficas, como os programas "Envelhecimento e Saúde" que engloba, na área da Promoção da Saúde, os projetos "Viva bem a idade que você tem", "Vida Ativa" e "Promoção da Saúde - SPES". Ainda não há uma documentação que avalie a participação da população na elaboração desses projetos por meio dos Conselhos de Idosos, de Saúde, ou outras organizações representativas (BRASL 1996).

Vale ressaltar aqui, algumas iniciativas existentes no sentido da formação de grupos voltados à Promoção da Saúde como tendências futuras, onde o critério não é 
o agrupamento por faixas etárias, nem por diagnóstico e sim o interesse por alguma atividade ou oficina, o que implica na participação dos idosos em grupos intergeracionais. De acordo com LIMA e PASETCHNY (1998) a organização desses grupos:

"tem como pressuposto comum que a segregação social ou em grupos, devido à idade da pessoa, não oferece oportunidade para trocas de experiências entre diferentes gerações, reforçando a discriminação e a mamutenção de conceitos estereotipados acerca da velhice" (p.41).

No contexto da saúde, a Terapia Ocupacional destaca-se, na atenção ao idoso, por oferecer um campo de tratamento voltado às questões da sua vida diária, do seu cotidiano e de suas necessidades bio-psico-sociais.

\subsection{Terapia Ocupacional e a saúde do idoso}

As qualidades curativas do trabalho, dos exercicios e dos jogos, expedientes comuns à Terapia Ocupacional, são reconhecidas e utilizadas há milhares de anos. Os povos antigos interrelacionavam essas três atividades para o tratamento do corpo e da alma (UNIVERSIDADE FEDERAL DE SÃO CARLOS 1996).

Com o advento dos ideais humanitários do Iluminismo, os hospitais europeus para doentes mentais passaram a utilizar diversas atividades como artesanato, exercícios e jogos para ocupar seus doentes. Mas foi somente no século XX que a Terapia Ocupacional se estruturou como profissão, principalmente para os indivíduos que se tornaram incapacitados fisica e mentalmente durante as guerras mundiais. No Brasil, o curso de graduação em Terapia Ocupacional foi reconhecido em 1969 e a profissão oficializada em 1971 (op.cit.).

BARBOZA (1996) afirma que é competência da terapia ocupacional criar, estimular e desenvolver condição e/ou situações que favoreçam o desencadeamento do processo terapêutico. Em Terapia Ocupacional este processo dá-se, essencialmente, pela inter-relação do paciente com o terapeuta, a atividade e/ou grupo, sendo que, nesta dinâmica, assume papel fundamental a pessoa do terapeuta 
como um dos elementos facilitadores e integradores do processo. O terapeuta ocupacional trabalha em estreita cooperação com outros profissionais e atua também nas áreas científica, educacional e administrativa. Nesta última, dirigindo, supervisionando e orientando serviços próprios em instituições públicas ou privadas, educacionais e assistenciais.

As intervenções em Terapia Ocupacional dimensionam-se pelo uso de atividades, elemento centralizador $\mathrm{e}$ orientador na construção complexa $\mathrm{e}$ contextualizada do processo terapêutico. Elas são avaliadas no contexto de cada caso e com 'o objetivo de promover o desenvolvimento, tratamento e reabilitação de indivíduos ou grupos que necessitem de cuidados fisicos, sensoriais, psicológicos e/ou sociais; de modo a ampliar seu desempenho e participação social (HAGEDORN 1999).

A Terapia Ocupacional tem tido uma atuação crescente na gerontologia, em sua prática tanto clínica quanto institucional. No Brasil essa atuação ainda é tímida, porém, nos países desenvolvidos tem se dado de uma forma mais expressiva, devido ao contingente populacional desta categoria etária. (CASELLI 1998).

No âmbito da gerontologia a terapia ocupacional encontra-se inserida em programas de atenção à população idosa, em instituições asilares e outras similares que abrigam e atendem os idosos. Nesta área desempenha um papel fundamental, propondo-se a estimular, através do uso da atividade, o autocuidado e a autonomia do idoso em suas atividades diárias, instrumentais e práticas, bem como no uso de suas potencialidades e habilidades remanescentes (CASELLI 1993).

Através de atividades grupais estimula-se no idoso a socialização. No grupo os membros são encorajados a repensar seus prévios julgamentos tentando novos comportamentos e atividades, são incentivados a reconhecerem suas necessidades e definirem áreas que querem explorar. $O$ interesse de um pode ajudar a definir os interesses de outros, ou sugerir novas possibilidades. O grupo é o lugar de compartilhar experiências, testar a realidade e receber encorajamentos. $O$ grupo pode ser usado como exemplo de como as pessoas se relacionam no aqui - agora (OSÓRIO 1986)

Como um profissional da saúde, o terapeuta ocupacional também participa de programas de prevenção de doenças e manutenção da saúde, preparando o idoso para 
os eventos inerentes ao seu envelhecimento (aposentadoria, menopausa, perdas), incentivando seu convívio social, familiar e sua autonomia. Com o estímulo ao autoconhecimento, o idoso tem condições de lidar com seus potenciais e, a partir daí, construir uma maneira própria de se relacionar com o meio social (FERRARI 1981).

A atividade pode ser um meio pela qual o idoso vivencie significado existencial através da auto-responsabilidade, do compromisso e de expressão de valores, envolvendo ainda o convivio social (op.cit.).

Embora a terapia ocupacional venha utilizando em sua prática uma gama extensa de atividades e instrumentos, neste trabalho será descrita a utilização do teatro enquanto recurso terapêutico e mais especificamente o teatro espontâneo do cotidiano. No próximo capítulo traz considerações a respeito desta modalidade de teatro $e$ as bases que o compõem. 


\section{Capitulo 4}

\section{O TEATRO ESPONTÂNEO DO COTIDIANO ENQUANTO UMA ESTRATÉGIA TERAPÊUTICA}

" mais uma vez a procissão em homenagem a Dionisio(Baco), deus do vinho, dirige-se para o local do culto. Todos cantam. Comovidos com a própria melodia, celebram aquele que lhes ensinara o delírio da embriaguez, a exaltação dos sentidos. E pouco a pouco, desprendem-se do cotidiano hostil: o rude trabalho, as tristezas, as injustiças.

Solenemente, no altar, o sacerdote prepara a cerimônia. Um bode é oferecido em sacrificio. Todos esperam o momento de ingerir a carne santificada. Próximo dali caminha Téspis, jovem com uma grande missão: desdobrar-se em vários seres, transmitir outras imagens, outros rostos que não o seu.

Ao redor do altar a procissão se aquieta por um instante, a fim de onvir as orações do sacerdote. Téspis penetra em Atenas agora com mais pressa, o coração tumultuado, uma estranha febre, a boca prestes a proferir qualquer coisa escandalosa, violenta.

O povo ainda não o vê, imerso que está ao sacrificio do animal. De repente Téspis abre a carroça e dela retira vários objetos bizarros, máscaras, cabeleiras, túnicas, sandálias. Depois se veste e arma a carroça como se fosse um altar.

O sacerdote recolhe o sangue. Distribui pedaços do animal entre o povo; que agora se embriaga de vinho e enlouquece de paixão. Os cantos aumentam. Subitamente, um grito maior que tudo corta o espaço. É Téspis, que afirma ser Dionísio: redivivo, encarnado. Silêncio. Apenas a figura mascarada domina a cena. Nos céus, Dionisio sorri. Mas Sólon, chefe do governo ateniense, acusa Téspis de ser o maior impostor da história humana: o primeiro ator."

(Maria Adelaide de A.S. do Amaral, in Teatro Grego - A Tragédia_MITOLOGLA - capítulo XLVIII) 


\section{Capítulo 4}

\section{O TEATRO ESPONTÂNEO DO COTIDIANO ENQUANTO UMA ESTRATÉGIA TERAPÊUTICA}

$\mathrm{O}$ teatro exerce um grande fascínio na humanidade desde tempos remotos. Ele propicia a possibilidade do homem "ser" outros personagens, de poder vir a ser a si próprio através de outros, de deixar de ser a si próprio sem deixar de existir, sem perder a consciência.

É impossível precisar quando deu-se o início da mimeses (arte de imitar), que auxiliou o homem em sua evolução, rumo à civilidade. A arte de representar serviu de intermediário entre o público e suas divindades, seus anseios, sua ação no mundo; através da representação o homem ensaia a vida e suas possibilidades(BOAL 1991).

O teatro é um instrumento adequado para o desenvolvimento da comunicação não-verbal, oral ou escrita. Permite a conscientização e o aprimoramento da percepção sensorial, da imaginação e da criatividade. Através da busca da boa expressão e da comunicação, através dos movimentos corporais, se desenvolve um melhor controle do corpo e de seus movimentos integrados ao espaço e ao tempo.

$O$ teatro tem se mostrado também um recurso terapêutico e um canal de expressão importantes, nas suas diversas manifestações.

Em terapia ocupacional a utilização do teatro como um meio terapêutico fazse, inicialmente, emprestando de suas correntes teórico-metodológicas, principalmente de suas ramificações terapêuticas, as bases para sua composição. Deste modo, ao construir a estratégia em terapia ocupacional denominada teatro espontâneo do cotidiano, busquei por esses conhecimentos. Ao iniciar essa jornada pela apropriação do teatro enquanto um excelente instrumento terapêutico, fui incorporando metodologias e técnicas de vários estudiosos e artistas, que fazem parte da esfera teatral e das vertentes terapêticas de orientação teatral. Neste capítulo discorrerei brevemente sobre as bases e tendências que influenciaram a construção do teatro espontâneo do cotidiano. 


\subsection{Bases teóricas e práticas do teatro espontâneo do cotidiano}

\subsection{1 principais autores inspiradores do teatro espontâneo do} cotidiano

Os Jogos teatrais de Viola Spolin forneceram algumas idéias para compor a parte prática introdutória do teatro espontâneo do cotidiano que consistem de atividades preparatórias e do uso de jogos teatrais para "desenvolver $a$ espontaneidade e improvisação", centrados na forma de aprendizagem cognitiva, afetiva e psicomotora e que serão citados com mais detalhes no encaminhamento metodológico deste trabalho, no capítulo 5 (SPOLIN 2001).

A teoria do jogo em Brecht- peças didáticas, trabalha os aspectos conceituais sobre a vivência do homem enquanto ser histórico e social. Nessas peças pretende-se estimular a capacidade de identificação e o repertório de ação dos participantes. Sua dramaturgia marxista propõe uma crítica histórica da vida cotidiana e da ideologia vivida. Brecht descreve o comportamento da linguagem cotidiana e privada colocando este comportamento e esta linguagem em uma perspectiva histórica, conclamando os homens a compreendê-los. O teatro de Brecht é um lugar de tomada de consciência política (KOUDELA 1991).

No teatro espontâneo do cotidiano o princípio é, em um primeiro momento, a vivência do cotidiano mais íntimo, que precede essa consciência política. Onde a perspectiva histórica ainda está mergulhada neste mundo-ao-redor. Em um segundo momento, esse ser social localizado em um contexto histórico e político pode emergir.

Neste sentido a concepção de Hegel citado por BOAL (1991), traz uma diferença fundamental que se opõe a essa forma brechtiana de conceber o drama, e que contribui para compreender as motivações espontâneas que direcionam a expressão:

"o caráter objetivo da ação que é apresentada diante dos nossos olhos e o caráter subjetivo dos motivos interiores, que movem os personagens e seu destino, que só podem ser o 'resultado necessário de suas paixões e ações' (....) a ação não 
parece nascer de circunstâncias exteriores mas sim da vontade interior e dos caracteres dos personagens" (op.cit., p.108).

O texto torna-se, assim, parte das cenas e ações produzidas pelos participantes, sendo o objeto do jogo teatral. Aí difere do teatro espontâneo do cotidiano, pois neste não há um texto que é formado, mas uma idéia, um foco, um tema, cuja linguagem está repleta de próprias falas e cenas cotidianas do grupo.

A peça didática de Brecht dá-se através da pobreza dos aparatos, simplificando e aproximando a relação do público com os atores e destes com o público. Cada expectador é, ao mesmo tempo, observador e atuante. Os padrões estéticos que são válidos para a construção de personagens nas peças épicas de espetáculo não têm função na peça didática, esta realiza-se por meio da imitação e crítica de modelos de atitudes, comportamentos e discursos. Ensinar/aprender tem por objetivo gerar atitude crítica e comportamento político. As peças didáticas são modelos que visam ativar a relação entre teoria/prática, fornecendo um método para a intervenção do pensamento e da ação no plano social (KOUDELA 1991).

Neste sentido, o teatro espontâneo do cotidiano propõe-se a incentivar as apresentações teatrais públicas. Essas apresentações têm o sentido de promover uma comunicação, tornando visíveis as realidades individuais vivenciadas enquanto sociais. Essas questões macrossociais emergem nas vivências do teatro espontâneo do cotidiano enquanto mobilizadores de conflitos individuais, trazendo à tona a concepção que cada integrante tem a respeito de seu "locus social". A partir da visibilidade proporcionada pelas apresentações, busca-se gerar uma reflexão das questões referentes aos papéis sociais dos idosos.

O pressuposto para a realização da peça didática é o "atuar para si mesmo" como ato artístico. Interferir na organização social. "O espectador precisa tomar partido em vez de se identificar", todos são atuantes na ação encenante (op.cit.).

Na obra de Eric Bentley (BENTLEY 1967), professor-catedrático de literatura dramática, algumas idéias influenciaram a concepção de teatro enquanto experiência. Para este autor, o teatro tem vida própria, os eventos não são dramáticos em si, o drama requer os olhos do espectador. Ver o drama em alguma coisa é perceber os elementos de conflito e reagir emocionalmente a esses elementos. A arte 
dramática é humana. "Até que ponto a nossa vida é dramática?"(p.18), é uma questão subjetiva. O que uma pessoa acha emocionante, outra pode achar aborrecida. Não se trata apenas da vida parecer dramática, desejamos que ela seja dramática. Por um lado, os grandes dramas das figuras nacionais, por outro, os pequenos dramas de cada um de nós, de cada dia.

Conforme contempla BENTLEY (op.cit.) com uma frase simples e profunda:

"temos a nossa vida; e no palco, têmo-la de novo" (p.22).

Estes princípios teóricos se afinam com a proposta do teatro espontâneo do cotidiano que se propõe a ser um canal de expressão de emoções, pois são elas que mobilizam as cenas, são elas que protagonizam as cenas reais do cotidiano, como uma re-vivência.

Dos diversos autores que tratam o teatro enquanto um meio terapêutico, Augusto Boal (BOAL, 1977, 1991, 1996) é o que mais influenciou a construção do teatro espontâneo do cotidiano, com seu teatro popular de rua. Este autor, dramaturgo e terapeuta, afirma que todo teatro é necessariamente político, porque políticas são todas as atividades do homem e o teatro é uma delas. De acordo com BOAL (1991):

"O teatro é uma arma muito eficiente. Por isso, as classes dominantes tentam se apropriar do teatro e utilizá-lo como instrumento de dominação. Mas, o teatro pode igualmente ser uma arma de liberação"(p. 13).

Para o mesmo autor, "O teatro" era o povo cantando livremente ao ar livre: o povo era o criador e o destinatário do espetáculo teatral, que podia então se chamar "Canto ditirâmbico" que era uma festa em que todos podiam participar livremente. Veio a aristocracia e estabeleceu divisões: algumas pessoas iriam ao palco e só elas poderiam representar enquanto que todas as outras permaneceriam sentadas, passivas. Estes seriam os espectadores, a massa, o povo (BOAL, 1977). 
Para Boal, no teatro espontâneo, a cena é sempre criação do momento, conquanto possa inspirar-se numa cena rememorada ou imaginada inicialmente pelo protagonista.

A des-dramatização é a repetição de uma experiência traumática, em situação controlada e que oferece a oportunidade de liberação de emoções intensas que não encontraram canal apropriado para se expressarem na ocasião em que ocorreram. Nele, a dramatização é um instrumento para se restabelecer o clima emocional originário e ensejar a purgação das experiências inconclusivas ou mal concluídas, e a desdramatização seria a chance de encontrar uma finalização diferente da original, para o episódio em questão, mediante a aplicação do principio da realidade suplementar (op.cit.).

Este é o eixo principal do teatro espontâneo do cotidiano que está baseado na mesma proposta de ação, ou seja, buscando os fatos do cotidiano e as questões conflitivas deste cotidiano e levando-as para a re-vivência teatral, explorando as diversas possibilidades de re-vivê-las, a construção deste "atuar" dá-se em um nível de redescoberta de si, de conscientização de si, enquanto ser que se relaciona e que pode ser transformador da sua própria realidade, tomando as rédeas de sua própria vida e "atuando" intencionalmente no mundo ao redor, enquanto ser social.

Outro autor de destaque é J.L.Moreno. Este, fundou em Viena, em 1921, "o teatro da espontaneidade" onde, utilizando as noções de espontaneidade e de improvisação dramática no "aqui-agora", propõe que as próprias pessoas atuem e criem o seu próprio teatro. A tarefa desta nova forma de teatro foi a de produzir uma revolução no Teatro, procurando modificar por completo os eventos teatrais. Rompendo a oposição entre ator e autor; entre pessoa e drama; criando a vida sem a necessidade de textos. Nessa forma de teatro desaparece a separação entre platéia e atores, podendo cada membro da platéia tornar-se ator e vice-versa (MORENO 1984).

Através desta nova forma de teatro, Moreno buscava o desenvolvimento pessoal e social do homem. Ele entendia que o homem é um ser que poderá desenvolver a "centelha divina criadora" que traz em si mesmo, a partir do impulso da espontaneidade (op.cit.). 
A teoria psicodramática dos papéis leva o conceito de papel a todas as dimensões da existência humana, desde o nascimento ao longo de toda vida do homem, enquanto experiência pessoal e modalidade de participação social. Tal concep̧̧ão entende que o existir humano é um viver em coletividade. Este enfoque se funda no princípio de que cada indivíduo e cada cultura caracterizam-se por uma variedade de papéis, que regem seus comportamentos que são impostos a todos os membros da sociedade (MORENO 1972).

Para Moreno, todo papel é uma fusão de elementos particulares e coletivos, dessa maneira o papel - conceito social - conecta com a espontaneidade, de conteúdo individual. Seus interesses estão voltados mais para os homens e suas relações do que para a cultura, os valores e normas sociais. Visam a espontaneidade e criatividade para que estes possam agir no mundo social. Cria e desenvolve técnicas e procedimentos operativos como recursos para que o homem possa atingi-los (op.cit.).

A teoria e a prática psicodramática traduzem uma postura filosófica basicamente existencial. Nela a improvisação teatral é fundada na espontaneidade, como fenômeno psicológico e estético. A principal categoria de uma filosofia do ato criador é o "momento" - momento de ser, viver e criar (RUBINI 2000).

No mesmo sentido as palavras de MARZANO (1999), sintetizam a concepção do teatro enquanto um agente transformador:

"o teatro conscientiza, estimulando o processo psíquico de vir do inconsciente para o consciente idéias e sentimentos reprimidos, ou seja, propicia o autoconhecimento, tornando-se um valioso auxilio, através da estrutura da dinâmica teatral, para a adequação social (....)" (p. 139).

Vários elementos da teoria do Psicodrama de Moreno, fundamentam a estrutura terapêtica do teatro espontâneo do cotidiano, enquanto estratégia. Culminando no ato de fazer emergir as emoções por meio de vivências dramáticas, outorgando-lhes o poder de transformação através da re-vivência, da troca de papéis e de diversas técnicas descritas mais detalhadamente no próximo item. 


\subsection{2 principais recursos utilizados no teatro espontâneo do} cotidiano

\section{a) teatro espontâneo, teatro da espontaneidade e psicodrama}

O teatro espontâneo é uma modalidade de teatro que pretende sintetizar todas as funções do teatro legitimo. Ele pode ser utilizado com finalidades especificas (estética, educativa, psicoterápica, socioterápica, entre outras) e a intenção com que é feito vai imprimir-lhe caracteristicas particulares (AGUIAR 1998).

O conteúdo expresso espontaneamente, por qualquer meio artístico, está direta e intimamente ligada com o mundo humano. Isto acontece mesmo que os elementos a serem reelaborados pela expressão e pela criatividade não estejam presentes, retidos apenas pela memória (LOPES 1989).

De acordo com AGUIAR (1998) o campo de atuação do teatro espontâneo subdivide-se em psicodrama, sociodrama e teatro espontâneo.

O psicodrama é o teatro espontâneo aplicado a situações em que cada participante procura algum tipo de crescimento individual, sendo o resultado pretendido a sua transformação (do participante), independente de suas modalidades e categorias (do psicodrama).

O sociodrama compõe-se da situação em que o teatro espontâneo é utilizado visando o desenvolvimento de um grupo preexistente, e que continuará existindo depois da intervenção. O objetivo que direciona a existência desses grupos, vinculase ao cotidiano da vida, diferentemente dos grupos formados para fins especificamente terapêuticos.

Ainda para o mesmo autor, o teatro espontâneo enquanto método básico, é uma modalidade de teatro interativo, cuja característica básica é a interação, sendo o texto e a representação criados no momento da própria apresentação. Esta caracteristica afina-se com a proposta de trabalho realizada no teatro espontâneo do cotidiano.

No teatro da espontaneidade tudo é improvisado, o palco desaparece, surgindo em seu lugar o palco-espaço, o espaço aberto, o espaço da vida. Ele é 
sempre uma peça única, que flui, se consuma no aqui-agora do ato vivencial dos atores-criadores(op.cit.).

No seu teatro do improviso, o desempenho de papéis foi a técnica fundamental do teatro da espontaneidade. Nas diferentes definições e concepções de papéis apresentadas por Moreno, pode-se notar que possuem algo em comum: são fenômenos observáveis que aparecem nas ações, são atuados e representam aspectos tangiveis do eu, passando do plano dramático ao social (MORENO 1983).

Para Moreno o "eu" é revelado pelo desempenho de papéis, então ele privilegia a técnica do "role-playing" com todo seu desdobramento pedagógico e terapêutico como jogo psicodramático de papéis. $\mathrm{Na}$ sua prática psicodramática, troca o objetivo teatral pelo terapêutico e procura provocar na mente do paciente um efeito catártico sugerindo que a improvisação seja aí condicionada a suscitar emoções, a "explorar a verdade" do sujeito que a pratica, revelando tanto a sua realidade como sua fantasia (MORENO 1983).

A principal diferença, entre o psicodrama e o teatro espontâneo do cotidiano é que a prática psicodramática não contempla a criação de textos, nem a composição de "peças teatrais" para serem representadas em público, o psicodrama se faz fundamentalmente em um "setting terapêutico" restrito. Estruturalmente o teatro espontâneo do cotidiano não apresenta as técnicas formais daquele, mas emprestalhe alguns passos na direção terapêutica.

\section{b) jogos dramáticos}

Através do jogo dramático a pessoa pode experienciar situações e papéis de uma maneira descompromissada com as convenções e regras que direcionam o convívio social. A vivência da simulação de sentimentos faz com que diversas emoções sejam simbolicamente enfrentadas durante os exercícios de preparação para a atuação e para a atuação de fato.

Segundo LOPES (1989), vivemos o jogo dramático com a memória que possibilita recuperar a experiência vivida ou imaginada. Reindentificamos o conhecido e ampliamos as nossas referências. Inúmeros são os beneficios para quem, inclusive, já perdeu alguma dessas habilidades e espaços sociais. Coração do teatro, 
seja na sua forma espontânea (fenômeno existencial) ou elaborado segundo uma concepção cênica. Está em jogo a capacidade de ver, ouvir, falar, apreender e aprender. A experiência intelectual que obtemos, praticando jogo dramático, não é um ato de análise distanciado e excludente da emoção e sensibilidade.

No jogo dramático espontâneo o atuante é a fonte de expressão, fazendo o jogo do autor-ator, portanto, a metamorfose- fenômeno básico deste jogo- aparecerá como resposta genuína do atuante interessado em transformar-se num outro, o que significa ampliar seu universo de comunicação, capacidade de expressão e criatividade (op.cit.).

\section{c) improvisação}

Para CHACRA (1995), o teatro nasce da improvisação. O caráter da improvisação encontra-se tanto no dia a dia como na vida artística, na forma de improvisação teatral sendo um elemento constituinte da vida teatral

A improvisação encontra em outros campos do conhecimento humano, como na psicoterapia e na educação, um significado e fundamentos maiores, tornando-se instrumento terapêutico e educativo, original e eficaz.

\section{d) teatralidade}

A teatralidade é um impulso primordial de transformação anterior à cultura, antecedendo o conceito de belo e estético. Ela possibilita ao homem uma maneira de expressão e comunicação anterior à simbolização verbal, através dos gestos e expressões corporais. Por meio dela foi criado o primeiro código de comunicação (GUINSBURG 1981).

Evreinov (1974) citado por GUINSBURG (1981), considera que o instinto de transfiguração faz parte da natureza humana, sendo encontrada nas mais diversas manifestações, nos rituais de povos antigos, nas festas populares, procissões e mesmo no cotidiano das sociedades atuais.

A teatralidade é uma atitude conducente que precede e determina o próprio papel do homem. É definida como o poder de simbolizar, representar, mascarar e 
assumir papéis e precede, qualquer forma de arte, não dependendo de um criador individualizado, nem está ligada à tentativa de representação (op.cit.).

Complementando a visão de Evreinov, a teatralidade é uma forma de expressão que está incluída na capacidade humana de produzir símbolos, deixando de ser instinto para ser representação passando a ser também um ato voluntário.

\section{e) simbolização}

Em nossa condição de seres humanos somos os únicos capazes de criar símbolos. Eles emanam de uma atividade cerebral espontânea, desconhecida na esfera animal. Daí vemos a espontaneidade em dois níveis: a espontaneidade instintiva (ocorre em qualquer processo vital- ligada aos sentidos) e a espontaneidade criativa (intimamente ligada às formas simbólicas - reino da concepção e da expressão). Qualquer processo de simbolização é produto da mente, justificando-se, assim, a existência espontânea de formas de representação simbólica na arte. Em todo ser humano existe um "eu criador" (CHACRA 1995).

O impulso da dramatização é inerente à personalidade e ao comportamento humano. Aparece no nível ficcional (faz-de-conta), como as representações dos homens primitivos (ritual) e as brincadeiras dramáticas das crianças ("jogo simbólico"), que surgem sem intenção, sem adaptação a um propósito consciente, como capacidade espontânea de representação dramática que, mais tarde, evoluirão para o teatro. Este impulso aparece também no próprio processo de viver, como uma capacidade do homem de efetuar transfigurações através do desempenho de "papéis", o sentido de simulação e dissimulação e o complexo que é a relação percebida "eu-eo-outro-no-aqui-agora", sendo a própria vida um fenômeno, senão idêntico, pelo menos muito próximo ao fenômeno teatral (op.cit.).

A imitação pode ser entendida como prefiguração da representação dramática. Pois, a simples e pura imitação, sem que ocorresse na mente o processo de transformação simbólica da reprodução experimentada, correria o risco de restringirse a uma imitação de caráter puramente animal (op.cit.).

É graças ao processo simbólico que o homem pode representar dramaticamente. É do cotidiano a propensão do homem para "criar" situações e faz 
parte corriqueira de suas atitudes, tantas são as vezes que o homem torna-se um atorum ator espontâneo, inconsciente, ao acaso (op.cit.).

Segundo a mesma autora, pode-se pensar em três niveis de experiência dramática:

- o subjetivo - ato espontâneo da representação egocêntrica da criança, assim como os sonhos e os devaneios;

- o expressivo - reação espontânea a uma situação real e presente, indicando o estado fisico e mental em que nos encontramos, significa auto-expressão, ou seja, dar vazằo ao que vai à subjetividade do indivíduo, sendo preenchida por atos emocionais de diferente natureza e sujeitos à variação espontânea;

- o teatral - essa expressão é repetida pelo puro jogo e desejo de expressão como conhecimento simbólico que extrapola o campo da existência real, o controle da espontaneidade, a consciência e o uso de um simbolismo específico e adequado, em função do qual, se diz que a representação dramática é teatral no sentido estético.

Concluindo este capítulo, onde pretendi delinear como estruturei o teatro espontâneo do cotidiano, devo acrescentar que essa construção não aconteceu de forma linear, mas foi o produto de anos de prática e de busca de bases teóricas para essa prática. Outra ressalva diz respeito à minha formação enquanto terapeuta ocupacional que utiliza o teatro enquanto recurso, não tendo formação especializada em psicodrama ou em dramaturgia, mas sim vivências nessas áreas.

No próximo capítulo discorrerei sobre a opção metodológica deste estudo e como deram-se os encontros onde utilizei o teatro espontâneo do cotidiano enquanto estratégia de acesso aos sujeitos da pesquisa e enquanto um recuso terapêutico. 


\title{
Capitulo 5
}

\section{CONDUÇÃO METODOLÓGICA DA PESQUISA}

\author{
"Nas marés da vida, na tormenta dos \\ fatos \\ Flutuo para cima e para baixo, \\ Ondeio para a frente e para trás \\ Nascimento e túmulo, \\ Um mar eterno, \\ Um tecer mutante, \\ Um viver ardente- \\ Assim trabalho no sibilante tear do \\ tempo, \\ Criando para a Divindade uma vívida \\ veste."
}

Johann Wolfgang Von Goethe, Fausto. 


\section{Capítulo 5 \\ CONDUÇÃO METODOLÓGICA DA PESQUISA}

\subsection{Direcionamento teórico metodológico}

Como expresso anteriormente, em um primeiro momento, o objetivo do presente estudo foi conhecer o significado do envelhecer para aquele que envelhece, utilizando o teatro espontâneo do cotidiano como um meio para a aproximação ao cerne da minha indagação. No decorrer da pesquisa, porém, encontrei que o significado da vida com as particularidades daquele que envelhece, emergiu de uma forma muito mais espontânea, nas vivências expressivas, do que o próprio significado do envelhecer, que foi buscado intencionalmente através da questão norteadora utilizada nos encontros, que discorrerei oportunamente.

A minha inquietação quanto ao significado do envelhecer foi além do que as ciências naturais explicam. Na prática profissional como terapeuta ocupacional e como pesquisadora, o sentido subjetivo do envelhecer, ocupou uma dimensão além do que poderia encontrar na literatura especializada. $O$ contato constante com pessoas idosas e com "envelhecentes", com suas histórias, anseios, dúvidas, preocupações, angústias e descobertas, impulsionaram-me a buscar na metodologia qualitativa algumas respostas, alguma compreensão de como o envelhecer mostra-se subjetivamente ao homem. A pesquisa qualitativa de orientação fenomenológica mostrou-se pertinente enquanto proposta metodológica, pois se aproxima do homem, buscando compreender aquilo que é vivenciado enquanto fenômeno. Uma investigação que se apoia no método fenomenológico, não parte de um problema com teorias explicativas, mas busca interrogá-lo a partir do seu cotidiano.

O termo fenômeno aqui empregado, entendido no contexto da fenomenologia, é "aquilo que se mostra à luz ou que pode ser trazido à luz. O que se mostra em si mesmo, o manifesto" (MARTINS e BICUDO 1994, p.22).

De acordo com esses autores, a pesquisa qualitativa questiona o valor da generalização, buscando uma compreensão particular do que estuda, existindo uma variedade de procedimentos metodológicos e de concepções desenvolvidas em todo mundo para satisfazer os aspectos qualitativos dos fenômenos pesquisados . 
No presente estudo, onde busco saber dos idosos, o sentido que o envelhecer assume em suas vidas, em pesquisa qualitativa de orientação fenomenológica, esse modo é chamado de "perspectiva de segunda ordem", segundo esses mesmos autores. Nessa perspectiva o "mundo ao redor" emerge dos significados que este mundo imprime a esses sujeitos, oferecendo diferentes percepções da realidade que é experienciada através dos sentidos* (op. cit., p.24).

Em pesquisa qualitativa os dados são coletados através da comunicação entre os sujeitos e tratados através da interpretação, aqui compreendida como um modo de ajuizar o sentido das descrições que levam a uma compreensão ou aclaramento dos seus sentidos e significados** (op.cit.).

A metodologia de pesquisa qualitativa escolhida para desenvolver este estudo é a fenomenológica, na modalidade "estrutura do fenômeno situado", de acordo com as orientações de Martins e Bicudo. Esta modalidade compõe-se inicialmente em situar o fenômeno, enquanto houver um sujeito em que esse fenômeno se situa, "há sempre um sujeito, em situação, vivenciando ou experienciando o fenômeno" Experiência esta, percebida de modo consciente pelo sujeito (op.cit., p.75).

De acordo com esses autores, essa experiência é denominada também de experiencial e possui característicos constitutivos como: tempo em que se realiza, impressões e duração. Essa experiência está sempre dirigida a alguma coisa, havendo uma relação entre o fenômeno que se mostra e o sujeito que o experiencia através de uma consciência intencional. Para estes autores o pesquisador ao adotar o modo fenomenológico de conduzir a pesquisa deve procurar "reavivar, tematizar e compreender eideticamente" os fenômenos da vida cotidiana, à medida que são vividos, experienciados e conscientemente percebidos (op.cit., p.76).

Reavivar o fenômeno significa fazer viver, torná-lo passível de experiência, através dos recursos utilizados pelo pesquisador, que neste estudo é representado pelo teatro e pelos relatos dos sujeitos acerca do significado do envelhecer para eles. Tematizar o fenômeno sugere estudar o fenômeno de forma sistemática, localizada.

\footnotetext{
- De acordo com Alfred Schutz (1962), citado por MARTINS e BICUDO (1994), a concepção da realidade a partir de "possibilidades de realidades múltiplas, compõe a concepção filosófica do realismo ingênuo, que propõe um acesso mais ou menos direto à realidade, experienciada através dos sentidos daquele que a experiência, o que possibilita diferentes percepções da mesma, segundo o acesso que se tem a essa realidade".

* Conforme afirmam os mesmos autores (op.cit, p.28): "a pesquisa qualitativa é considerada, hasicamente descritiva".
} 
Compreender eideticamente o fenômeno é ver o modo peculiar, específico e único do objeto existir na sua intenção total, na sua essência e não apenas na sua representação (op.cit.).

A partir dessas considerações, serão destacadas algumas conceituações e trajetória do método fenomenológico, além de autores que utilizam a fenomenologia enquanto metodologia, que mais se aproximaram ao meu modo de conceber o homem, sendo os mais expressivos na composição deste estudo. Entretanto, não pretendo aprofundar-me na sua especificação, uma vez que estou iniciando no processo desse referencial enquanto terapeuta ocupacional; buscando apenas fundamentar as bases teóricas que nortearam este trabalho.

A palavra fenômeno (aquilo que aparece) foi usada na filosofia desde Platão e Aristóteles, adquirindo no decorrer do tempo um sentido cada vez mais subjetivo.

Em Husserl, desliga-se completamente da relação a qualquer objeto exterior à consciência, referindo-se ao puro objeto imanente enquanto aparece na consciência.

No início do século XX, a fenomenologia afirma-se com Husserl combatendo o psicologismo reinante, que pretendia explicar todo o pensamento como resultado da ação das condições psicológicas do indivíduo trazendo uma nova discussão, configurando-se como um viés necessário à compreensão da práxis social. Para Husserl, a fenomenologia é uma ciência dos fenômenos e não dos fatos, uma ciência das essências. A máxima "às coisas elas mesmas" fundamenta sua teoria (CAPALBO 1996).

Para esse pensador, a fenomenologia consiste na análise dos atos de visar um objeto que caracteriza a consciência intencional. Ela se interessará pela descrição dos atos mediante os quais eu percebo os objetos. Husserl chamará esses atos de Noesis da percepção. Eles são significativos para o sujeito.

Husserl chama de Noema a maneira original de um objeto se dar à percepção ou à imaginação. Portanto a cada Noesis corresponde um Noema correlativo. À Noesis corresponde o lado das vivências subjetivas e ao Noema o lado das vivências objetivas. Como colocam MARTINS e BICUDO (1997):

"deseja-se que os sujeitos façam uma descrição noemática de forma que as referências noéticas possam ser avaliadas (....) são elas que clarificam e auxiliam a 
interpretar as estruturas vividas, baseando-se na evidência dos dados descritos" (p.94).

Husserl elabora um método de depuração rigorosa que consiste em fazer reduções das partes questionáveis ou sujeitas a deduções e contradições. Toma como objeto o fenômeno puro (consciência intersubjetiva) acerca do qual não poderá haver nenhuma dúvida. Seu método de evidenciação é o método descritivo, que explora a intuição pura na presença do objeto e rigorosamente analítico, buscando averiguar tudo o que se pode incluir como experiência transcendental (FRAGATA 1962).

O primeiro passo do método é denominado "Epoché", que significa pôr em suspensão ou entre parênteses e sugere a descrição do objeto da experiência como se tratasse de um primeiro encontro (GOMES 1997).

O segundo passo do método consiste na exploração ou investigação do material descrito, podendo ser realizada através de perguntas à descrição, de modo a explorá-la exaustivamente. Ao esgotar as perguntas possiveis, verifica-se que partes identificadas na descrição podem ser retiradas sem comprometer a estrutura ou essência do objeto. Conclui-se o segundo passo com a preparação de uma nova descrição. Esta segunda descrição mostra a nova consciência do objeto da experiência. O objeto está definido, as partes identificadas e as distinções entre o essencial e o não-essencial indicadas (op.cit.).

No terceiro passo revela-se o direcionamento ou intencionalidade da consciência para aquele determinado objeto da experiência, chegando-se então ao sentido que aquele objeto assume para a consciência. Na teoria de Husserl, chega-se a este sentido através das várias modalidades dos processos mentais. Estes processos são conhecidos como afeição (eu sinto), conação (eu julgo) e cognição (eu penso). $\mathrm{Na}$ verdade, Husserl procurava neste último passo do seu método um eu submerso na experiência. Assim, a investigação chega ao fim com a descoberta da intencionalidade do outro. O que possibilita a experiência de acesso à consciência do outro é a intersubjetividade - uma subjetividade comum a duas ou mais pessoas. $\dot{E}$ este eu puro que pode apreender, sem perigo de erro, tudo o que se lhe apresentar como fenômeno da consciência, chegando desta forma a um idealismo transcendental fenomenológico (op.cit.). 
A tese fenomenológica criada por Husserl e mais tarde reinterpretada por outros autores, propõe significados à reflexão, pela redução do objeto a ser investigado e estudando-o de modo mais profundo - como um foco de luz a iluminar algo a ser apreendido para libertá-lo ao mundo(op.cit.).

Para Heidegger, que foi seu assistente e depois sucessor na Universidade de Friburgo, essa tese refere-se a algo que se mostra desfigurado ou velado, o qual a fenomenologia deve "fazer ver" ou ao sentido de algo que pode encontrar-se velado e tornar-se fenômeno quando desvelado (HEIDEGGER 2002).

Para este filósofo, o fenômeno não é somente a manifestação da consciência e da subjetividade transcendental, como diz Husserl mas, uma revelação do ser, pois este se apresenta como é e como se manifesta. O sujeito transcendental de Husserl é substituído pela existência em sua facticidade, o que Heidegger chamou de Dasein termo de dificil definição e tradução - o ser-aí ou ainda pre-sença (DARTIGUES 2003).

Para compreender a questão do ser, Heidegger priorizou dois pontos de vista: o ontológico- onde "para se chegar ao ser, é preciso compreender o que funda o conceito de ser como aquilo que é; e o ôntico - onde para se chegar ao ser, é preciso partir do ente, pois ser é sempre o ser de um ente". O termo pre-sença faz referência ao processo de constituição ontológica do homem (MELO 2003, p.69).

A pre-sença designa o homem na medida em que o homem é este ente singular que é para si próprio uma questão. A essência da pre-sença reside em sua existência, compreendendo por existência, esta emergência ao Ser que o homem descobre antes de toda definição de si próprio, antes de todo pensamento e antes de toda linguagem; a interrogação que o homem traz em si antes de formulá-la porque ele é essa interrogação. O homem é o único "Eksistente" o único questionador entre os outros entes dos quais podemos dizer que são, mas não que existem (DARTIGUES 2003; HEIDEGGER 2002).

Para Heidegger a existência é sempre minha, sempre pessoal. Para compreendê-la Heidegger analisa a existência cotidiana, banal. A existência cotidiana está sempre no mundo e com os outros, pois existir é ser-no-mundo-comos-outros. Ao existir, a pre-sença assume sua facticidade, significando que foi 
lançada no mundo, numa situação, sem oportunidade de escolha assim a pre-sença é ser-no-mundo (MELO 2003, p.69).

A pre-sença por ser o ser-no-mundo, não é apenas uma coisa e sim a sua própria existência. "Constitui-se por suas relações com o ambiente das coisas (Unwelt), e de outras pessoas (Mitsein)", diferindo neste ponto, de Husserl que com a sua "epochè" pretende colocar entre parênteses a própria existência (GILES 1975, p.227).

A natureza da pre-sença é ser-em-comum, uma existência compartilhada de interdependência social de sua experiência cotidiana. "A plena autoconsciência e a auto-afirmação derivam da consciência que tenho dos outros". A pre-sença é constituída pela solicitude que sente pelas pessoas que compartilham sua existência e pelas preocupações que condicionam o uso que faz dos objetos como utensílios. A pre-sença está num mundo com utensílios e com outras pre-senças, esse é o mundo da existência humana. $O$ conjunto do complexo de referências ao outro e de significados é que constitui o mundo como mundo-ambiente, pensado como o domínio de onde vem um sentido. "Afirmar que a pre-sença é ser-no-mundo quer dizer que ele é seu mundo pela familiaridade que tem com ele", sendo o mundo o ambiente em que a pre-sença pode revelar-se sempre como totalidade (GILES 1975, p.231).

"Pois não existe homem sem mundo e nem mundo sem homem" (MELO 2003, p.70).

A partir deste ponto, a fenomenologia muda de orientação não se contentando mais com a descrição do que se dá ao olhar, mas a interrogação do dado que aparece, como um texto a compreender, interpretar - hermenêtica-, neste aspecto Heidegger considera que o desvelamento da pre-sença fundamenta a compreensão da existência (essência) humana, pois não há, para ele, uma separação entre compreensão, ser e mundo (DARTIGUES 2003).

O existencial em que se concentra a possibilidade de sucesso do método fenomenológico é a compreensão. É através dela que a pre-sença está sempre aberta, nela se esboça a matriz do método fenomenológico heideggeriano, uma vez que a 
compreensão possui uma estrutura em que se antecipa o sentido. Toda a explicitação da pre-sença cotidiana repousa, portanto, nesse pressuposto (GILES 1975).

E o ser, ao revelar-se na linguagem, expressa a compreensão e o pensamento do homem. Assim, a problemática interpretativa se impõe à dimensão ontológica e a ontologia descobre a sua base hermenêutica, a qual resgata da história do ser a sua visão ôntica. Deste modo, entende-se que a ontologia é fenomenologia e esta é hermenêutica (DARTIGUES 2003).

A existência traz em si os recursos de sua compreensão e é desses recursos que a hermenêutica lança mão. A análise existencial da pre-sença decompõe, em seus diferentes momentos, esta estrutura fundamental que é o ser-no-mundo, porque ele é seu mundo, ele tem uma pré-compreensão desse ser-no-mundo que se manifesta pelo sentimento de situação, que por sua vez, se articula com a dimensão da compreensão. Pela compreensão a pre-sença está lançada no modo de ser do projeto. Entre o sentimento de situação, o estar lançado e o projeto aparece uma tensão dinâmica, um movimento de vai-vém que cava a fenda onde vão nascer as questões e de onde vai surgir o sentido, e mais profundamente o Ser (op.cit.).

O ser somente se revela sob o ente, num retorno sobre a pre-sença, tornandose decisivo pôr a nu os modos de dissimulação em que se situa a própria pre-sença, na sua cotidianidade. Heidegger descobre a pre-sença no movimento de fuga de si mesmo, numa tentativa de não se assumir na sua totalidade. A pre-sença se vela para si mesma, encobre suas possibilidades barrando a possibilidade de uma revelação de ser. Através da análise da cotidianidade pode-se descobrir nela o homem no movimento de fuga. Somente realizada a analitica da pre-sença cotidiana, se descobre como a pre-sença pode assumir-se pela decisão enérgica, na sua verdade, para descobrir que sempre está simultaneamente na não-verdade. Este interesse pela não-verdade é o sinal da fuga de si mesmo (HEIDEGGER 1971).

Considera-se neste estudo que o teatro espontâneo do cotidiano possibilita a expressão desse cotidiano, sendo um meio dotado de possibilidades.

A escada para penetrar nas estruturas existenciais da pre-sença, é manejada pela própria pre-sença e não pode ser preparada fora para depois penetrar no objeto. A escada já está implicada naquilo para onde deveria conduzir. O objeto, a presença, traz consigo a escada. Há uma relação circular. Somente subimos para as 
estruturas da pre-sença, porque já nos movemos nelas. É apenas uma questão de explicitação. A análise da pre-sença está suspensa no ar (op.cit.).

Com esta premissa, a contribuição de Heidegger imprime uma reflexão mais ampla da teoria da hermenêutica, em comparação com seus antecessores (em especial, Husserl e Dilthey) (FREITAS 2002).

Buber, contemporâneo de Heidegger, apresenta algumas formulações a respeito da relação do ser humano com seus semelhantes, diferentes das de Heidegger, onde afirma que o homem apresenta duas maneiras diferentes de ser-nomundo, que denomina: $E u$-Tu, atitude básica anterior ao Eu como ser consciente, onde o homem existe numa completa integração no mundo caracterizada pelo envolvimento; e o Eu-Isso, onde existe uma separação entre o homem e o mundo, que existe independente daquele e caracteriza-se pela separação (FORGHIERI 1984).

De acordo com Buber citado por BENTLEY (1967):

"Nas confluências que não logram ser encontros, estamos reduzindo as pessoas a coisas, ou por outras palavras coisificando os nossos semelhantes. Num encontro, o outro homem é inevitavelmente um Tu" (p.71).

A realidade da palavra princípio Eu-Tu provém de um vínculo natural, cósmico, que se dá no amor. O amor acontece entre o $E u$ e o $T u$. No amor desaparecem as peculiaridades e as contradições, englobando uma oferta da infinita possibilidade e um risco de ser completamente, sem ocultar nada de si, sendo imediata e acontecendo no momento presente. No entanto, o $T u$ tende a se transformar num Isso, numa coisa entre as coisas, permanecendo em estado latente, sempre pronto a reaparecer.

"Vivemos muma alternância entre essas duas atitudes, sendo que a maior parte do tempo permanecemos em Eu-Isso, pois o Tu dura apenas alguns instantesnão conseguimos retê-lo" (FORGHIERI 1984, p.20). 
O movimento fenomenológico também influenciou o pensar e o fazer fora do meio filosófico. Terapeutas europeus aplicararam em sua práticas os pressupostos fenomenológicos, voltando-se para a compreensão do paciente em sua realidade, ao invés de conhecê-lo através de teorias. Só para citar duas dentre muitas: a Gestaltterapia e o Psicodrama de Moreno, utilizaram os pilares da fenomenologiaexistencial em suas teorias (op.cit.).

Uma nova forma de tratar terapeuticamente o homem veio a constituir o movimento analitico existencial ou Daseinsanalyse (HEIDEGGER 2001).

Destacando entre esses terapeutas nomes como L. Binswanger, R. Jaspers, que foram os primeiros psiquiatras a aplicar a fenomenologia de Husserl à Psicologia e à Psiquiatria. Em seu estudo, Binswanger considera que o conhecimento fenomenológico, próprio das ciências do homem, começa com a percepção categorial, que capta por intuição a essência de coisas e processos (op.cit.).

De acordo com este terapeuta, a análise do ser-no-mundo mostra, a cada momento, as características do seu existir, sua maneira de vivenciar o espaço e o tempo. A existência humana flui numa oscilação ascendente ou descendente, de acordo com seu humor. O homem, portanto, não é apenas ser-no-mundo inseguro e angustiado, como afirma Heidegger, podendo superar a preocupação inerentes à concretude de sua vida, existindo não apenas como "eu" mas também como "nós", na plenitude do amor, como acontece na relação $E u-T u$, "denominada por Binswanger de modo dual de existir". "O amor é o reverso ontológico da preocupação, onde o homem supera a anguistia de sua condição humana, e vivencia uma completa integração ao mundo, o existente transcende o tempo e o espaço" (op.cit., p.22).

Outro terapeuta de orientação fenomenológica de destaque foi Boss, amigo pessoal de Heidegger, que também reconhece a relevância do amor na existência humana e concorda com a importância atribuída por Binswanger à forma dual de existir, mas considera que este não compreendeu devidamente Heidegger ao contestá-lo. Boss afirma que a análise existencial procura ver o homem tal como se revela imediatamente e descobre que ele existe apenas em sua relação com os objetos e seus semelhantes. Para ele o modo humano de ser-no-mundo é comparável ao resplendor de uma luz, cuja claridade pode tornar presente tudo o que existe, 
revelando sua natureza. Ao abrir-se ao mundo, iluminando-o, descobre além de coisas, os homens que estão com e como ele. "Para Boss, a tarefa intrinseca do homem é cuidar de si, das coisas e de seus semelhantes, só assim pode alcançar a plenitude de seu existir" (op.cit., p.23).

Discipulo de Binswanger, Van Den Berg, procura mostrar a importância do conhecimento das percepções categoriais da pessoa para que possamos compreendêla. Aqui não se trata de captar a sua subjetividade, mas o modo como ela percebe os objetos, as pessoas e a si própria situada no mundo.

As nossas vivências cotidianas não estão contidas somente dentro de nós mas se manifestam relacionadas ao ambiente, às pessoas, às situações nas quais nos encontramos ou às quais nos reportamos pela imaginação. Por este motivo a psicologia se interessa pela percepção categorial, pela maneira peculiar que a pessoa tem de ser-no-mundo, de captar os objetos, as pessoas e as situações(op.cit.).

A terapia ocupacional em seu conjunto de bases filosóficas e pressupostos teóricos da prática, contempla a visão fenomenológica do homem. Apesar de grande parte dos conhecimentos básicos da Terapia Ocupacional derivarem de ciências reducionistas biológicas, comportamentais e médicas. No entanto existe uma crescente aceitação e validade de métodos de orientação fenomenológica no contexto da terapia ocupacional. O terapeuta ocupacional é preparado em sua formação a considerar o contexto, o significado e a natureza subjetiva da experiência (HAGEDORN 1999).

Todas as escolas de psicologia exerceram influência sobre a Terapia Ocupacional de diferentes maneiras e em momentos diferentes. Dentre estas, destaco a psicologia humanista que é descrita como fenomenológica, porque se ocupa da experiência individual subjetiva, da "visão de mundo" pessoal que cada ser humano desenvolve como resultado de sua própria vida, sentimentos e percepções. Dentre seus principais teóricos destacam-se Maslow, Frankl, Kelly e Rogers(op.cit.).

A partir destas considerações, tento aproximar-me das bases teóricometodológicas que orientaram este estudo, fenomenológico por essência. 


\subsection{Como caminhou este estudo}

\subsubsection{O grupo e os encontros}

A principal intenção nesta investigação foi ouvir das próprias pessoas que estão envelhecendo, qual é o sentido do envelhecer em sua existência, utilizando o teatro enquanto um meio de acesso a elas, e interrogando esse "envelhecente" a partir da questão orientadora: "qual o significado do envelhecer para você??"

Sendo assim, não existem, a princípio, hipóteses a serem testadas nem a proposta de desenvolvimento de um método terapêutico, embora utilize-se de uma modalidade terapêutica - o teatro espontâneo do cotidiano - que propicia o acesso a essas pessoas, o objetivo é o de compreender da pessoa que o vivencia, o fenômeno do envelhecer.

Usualmente as pesquisas de abordagem fenomenológica na área da saúde recorrem a entrevistas individuais, onde, a partir da indagação original, busca-se por um desvelamento do fenômeno subjetivo. No entanto, como as atividades desenvolvidas na intervenção terapêutica são grupais, optei por escutar essas pessoas no próprio espaço grupal

A situação grupal possibilita uma interação entre os participantes que se reúnem em torno de objetivos comuns. Através dessa forma de encontro social é possivel observar a identificação que surge quando as pessoas colocam suas questões e estas são também pertinentes a outros participantes do grupo. No caso de grupos cujos membros convivem em seu cotidiano ou fazem parte da mesma esfera cultural ou mesmo geracional, essa identificação é bastante observável. A expressão de uma pessoa do grupo pode suscitar questões semelhantes em outra, estimulando sua expressão, a situação grupal é, portanto, facilitadora deste aspecto expressivo (OSÓRIO et al. 1986; GRINBERG et al 1976).

Um grupo transcende a simples soma de seus integrantes com seus problemas pessoais. O encontro destes com o terapeuta, "cria um campo grupal dinâmico", no qual emergem e se entremeiam desejos, necessidades, medos, culpas, ataques, defesas, identificações, resistências articuladas entre si de tal modo que a alteração 
em um deles vai repercutir sobre os demais. Embora os objetivos comuns aproximem as pessoas integrantes do grupo, suas individualidades acham-se respeitadas (OSÓRIO et al. 1986).

Assim, apesar dos objetivos em comum, as individualidades são preservadas e, muitas vezes, ressaltadas. Neste sentido, o trabalho grupal mostrou-se como condição facilitadora, uma vez que, em teatro, esta (a situação grupal) é uma exigência quase que obrigatória.

$\mathrm{O}$ acesso àqueles que vivenciam o envelhecer, aconteceu junto às pessoas vinculadas à Unidade Básica de Saúde Simioni, localizado no bairro Simioni, na cidade de Ribeirão Preto no interior de São Paulo. Essas pessoas participam dos grupos formados no Programa de Aprimoramento Multiprofissional em Hipertensão Arterial e Diabetes Mellitus, cuja proposta consiste no treinamento de profissionais em serviço para formação de educadores em Hipertensão e Diabetes, que ocorre através da Secretaria Municipal da Saúde de Ribeirão Preto, em parceria com a FUNDAP (Fundação Desenvolvimento e Apoio à Pesquisa). Este Programa abrange as Unidades Básicas e Distritais de Saúde de Ribeirão Preto (UBDS- RP): Central, Simioni, Vila Mariana, Castelo Branco e Bonfim Paulista.

Grande parte das pessoas assistidas por este programa, têm, em média, 60 anos e mais, o que possibilitou realizar a parte prática deste estudo.

A partir de um convite formal recebido por esta Secretaria solicitando que eu coordenasse grupos expressivos de idosos vinculados à esse Programa, foi também concedido um espaço para eu realizasse a coleta de dados.(ANEXO 2). Esses grupos expressivos aconteceram inicialmente em duas Unidades de Saúde indicadas pela equipe de profissionais atuantes neste programa: a UBDS - Central e a UBDS Simioni.

O trabalho de coleta de dados, junto a esses grupos expressivos, contou com a participação voluntária de uma terapeuta ocupacional e de uma fonoaudióloga que atuaram como coadjuvantes nas encenações e também realizando as filmagens.

No primeiro contato com o grupo foi explicitada a proposta do trabalho e seu caráter de pesquisa científica. Foi então combinado, deixando todos bem à vontade para que se manifestassem de forma espontânea, que, devido ao caráter aberto do grupo, qualquer pessoa poderia entrar e sair quando lhe coubesse. 
Os participantes foram informados do objetivo do estudo, preenchendo e assinando o Termo de Consentimento (ANEXO 2), atendendo às exigências éticas e fundamentais de estudos que envolvem seres humanos, tendo sido aprovado pela Comissão de Ética da Faculdade de Saúde Pública da USP- SP.

Como foi concedido e até proposto pelo grupo, foram realizados filmagens de vários encontros, a partir do terceiro encontro.

Este trabalho expressivo serviu de modelo e foi reproduzido pelas duas colaboradoras anteriormente citadas na UBDS Central. No entanto, para efeitos da análise de dados, sob uma perspectiva fenomenológica, somente o grupo pertencente à UBDS do bairro Simione está incluído no presente estudo.

Para que as pessoas participassem do grupo expressivo, não houve um critério de seleção específico, uma vez que todas já faziam parte do Programa citado anteriormente, única condição necessária.

Os encontros para a realização do grupo expressivo aconteceu em um local cedido pela comunidade, o salão paroquial da igreja próximo à unidade do bairro onde residem as participantes.

Foram realizados 12 (doze) encontros, uma vez por semana, com duração variando de uma hora e meia a duas horas de duração.

Os temas trazidos e vivenciados durante os grupos foram bastante diversos, pois partiram das elucidações e necessidades trazidas pelos próprios participantes do grupo.

Participaram deste trabalho um total de 30 pessoas, todas com diagnóstico clínico de Hipertensão Arterial e /ou Diabetes Mellitus que faziam parte de outras atividades desenvolvidas dentro do programa como: grupo de ginástica, relaxamento, psicoterapia, entre outros.

O grupo da UBDS - Simioni, local onde deu-se este estudo teve uma média de 8 (oito) participantes por encontro. Embora o total de participantes durante a coleta chegou a trinta pessoas, havia um número flutuante e uma variação dessas em cada encontro. Esse fato não alterou os objetivos e nem a condução do trabalho, uma vez que o grupo tem um caráter aberto e onde cada encontro encerrava-se em si mesmo, característica dessa forma de teatro. Portanto os encontros não eram 
sequenciados e nem apresentavam uma continuidade planejada entre si, ressalvo o desejo das participantes, que tinham uma presença mais constante durante o trabalho.

A média de idade das participantes é de 60 anos, sendo todas do sexo feminino. A grande maioria são pessoas aposentadas, e possuem um baixo nivel sócio-econômico* .

Em todos os encontros, ao iniciar o trabalho e/ou ao final deste, eu lhes apresentava a questão orientadora: "Qual o significado do envelhecer para você??".

Os temas trazidos para o teatro foram as próprias vivências cotidianas, expressas pelos membros do grupo. Poder representar o próprio dia-a-dia através do teatro abre uma série de caminhos que possibilitam entender a história de cada um, quais são os processos do envelhecer e também do próprio adoecer. Com o jogo do faz-de-conta, recurso fornecido pela vivência teatral, surge uma possibilidade para as pessoas colocarem-se mais descontraidamente, mesmo que de forma indireta. No entanto, na realidade, são elas próprias podendo debater, questionar e representar a situação em que vivem.

Representar a própria vivência cotidiana possibilita trazer à luz aspectos que são significativos para uma apropriação de si e que podem estar velados. Os questionamentos permitem a manifestação de inquietações individuais e grupais. $O$ debate grupal propicia uma tomada de consciência de questões comuns, possibilitando vislumbrar novas alternativas para lidar com essas questões, repensando as estruturas desse cotidiano na direção de uma melhor qualidade de vida.

Ao emergirem as situações cotidianas e essas serem tratadas de uma maneira reflexiva, abrem-se possibilidades de encontrar soluções para os conflitos e dificuldades, buscando alternativas condizentes com suas realidades e crenças.

Considerando esses aspectos, através do teatro espontâneo como uma estratégia terapêutica e um canal de acesso às questões individuais e grupais na busca de resoluções e alternativas condizentes às realidades contextuais, estaremos promovendo a saúde.

A estratégia de trabalho, teatro espontâneo do cotidiano, desenvolvida em cada encontro compõe-se de alguns passos: inicia-se por uma conversa informal;

\footnotetext{
* esses dados (vinculação a algum tipo de atividade profissional, grau de escolaridade, renda mensal, entre outros indicadores sócio-econômicos) não foram objetivamente coletados, uma vez que o enfoque deste estudo não se volta para caracterizações sociais dessa natureza, portanto julguei serem dispensáveis.
} 
seguida pelos depoimentos motivados pela questão norteadora; por um levantamento de temas a serem representados; por atividades e exercícios preparatórios, integrantes do próprio processo de vivência teatral; pela dramatização propriamente dita; um debate final, onde em algumas oportunidades foi colocada novamente a questão norteadora; um fechamento do encontro contando com as impressões pessoais das participantes; e conclusões da terapeuta que coordenou o grupo.

A conversa inicial tinha como finalidade possibilitar o relato informal e espontâneo de como as participantes haviam passado a semana ou comentassem fatos ou algo que tivesse acontecido com elas, com pessoas conhecidas e até mesmo com familiares.

Após essa conversa inicial a questão norteadora era lançada e todas as participantes eram convidadas a discursarem individualmente sobre o significado do envelhecer para si. Embora os relatos fossem individuais, essa questão suscitava muitos debates grupais e entrelaçamento de depoimentos.

O passo seguinte envolvia o levantamento das questões mais destacadas pelo grupo nos dois primeiros passos ou alguma questão individual que o grupo favorecia e se propunha a dramatizar.

Eleito o tema a ser re-vivenciado ou dramatizado, iniciava-se uma série de atividades e exercícios específicos subdivididos nas etapas descritas a seguir: 


\section{Etapa I - exercicios preparatórios de aquecimento}

Esta etapa foi composta por uma série de atividades utilizadas com o propósito de propiciar uma melhor interação e integração entre os participantes e uma auto-expressão adequada. Foram propostos diversos exercícios que envolviam a movimentação corporal e os sentidos, com a finalidade de se desenvolver a propriocepção, a ampliação dos sentidos e da atenção das participantes do grupo para que percebessem suas tensões e realizassem um relaxamento global, bem como estivessem preparadas para iniciar a etapa seguinte.

Foram constituídos basicamente por técnicas de relaxamento, exercícios de respiração e exercícios de conscientização e expressão corporal.

\section{Etapa II - dinâmica grupal}

Nesta etapa foram realizados exercícios dramáticos e dinâmicas grupais, visando a interação e a descontração das participantes do grupo. Tratou-se de um aquecimento antes de iniciar a dramatização propriamente dita. Estes exercícios buscavam a desinibição das participantes e a exploração de seus potenciais criativos, propiciando um melhor contato entre elas.

Foram constituídos basicamente por: brincadeiras, jogos dramáticos, técnicas de improviso teatral e de interação grupal.

\section{Etapa III - questionamentos e dramatizações do cotidiano}

Nesse momento, após o evidenciamento do tema, geralmente destacado pela coordenadora, tinha início a vivência teatral espontânea. Os membros do grupo e principalmente aquela pessoa que era o foco da encenação, conjuntamente com a coordenadora e terapeutas auxiliares faziam as escolhas de papéis. A encenação iniciava-se e todos participavam voluntária e espontaneamente na elaboração do "cenário" e na composição do setting teatroterapêutico. As dramatizações teatrais objetivaram a revivência de cenas cotidianas, recriando-as novamente através da encenação, possibilitando novos direcionamentos, soluções, adequações, 
descobertas... As falas no teatro espontâneo aconteceram sem qualquer tipo de direcionamento, de memorização, de ensaio, todas as construções, desconstruções e reconstruções das cenas foram espontâneas, pois partem das necessidades reais, das próprias vivências e das próprias possibilidades de cada uma.

Todas as dramatizações envolveram o próprio cotidiano das pessoas, seus desejos e anseios, enfim tudo o que elucidasse o significado que tem o envelhecer para cada uma, ou seja, a forma como estas vivem e encaram seu ser-no-mundo

Os temas mais abordados foram: questões sobre direitos e cidadania, representação social do idoso, serviços de saúde, relacionamento familiar, o tratamento das pessoas idosas em diversos locais como: no transporte urbano público tradicional, em uma Unidade de Saúde, lugar muito freqüentado por esta população, entre outros.

\section{Etapa IV - preparações e ensaios teatrais}

Essa etapa e a seguinte poderiam ou não serem incluidas no processo, pois estariam sujeitas ao desejo do grupo em realizar uma apresentação pública.

A partir dos temas trazidos pelas participantes nos encontros e vivências encenadas, criaram-se peças teatrais utilizando a técnica do teatro espontâneo ou improviso, que foram reproduzidas em vários eventos públicos, pois assim desejaram os membros do grupo. A técnica do teatro espontâneo baseia-se no improviso de falas e gestos, mas possui um fio condutor bem direcionado. Uma vez que os temas vivenciados fazem parte dos seus cotidianos, o grupo não apresentou e nem expressou essa dificuldade na encenação pública.

Os temas nessas encenações foram ao encontro das vivências mais significativas apresentadas nos encontros, destacando-se a vivência nos serviços de saúde, enfocando aí o tratamento dispensado ao usuário do Sistema Público de Saúde e soluções desejáveis para que esse acesso fosse de melhor qualidade. Outro tema foi a vivência em um transporte coletivo e todas as intempéries que ocorrem àqueles que têm algumas dificuldades, como é o caso das pessoas de idade avançada. 


\section{Etapa V - apresentação teatral}

Esta etapa consiste na apresentação formal do trabalho desenvolvido pelo grupo e envolveu os participantes de uma maneira distinta daquela ocorrida nos encontros. Para que as peças fossem apresentadas, as participantes reuniram-se em outros horários e espaços (nas próprias casas e, previamente, nos locais onde essas apresentações ocorreram), a fim de realizarem "ensaios", elaboração de figurinos e reconhecimento do espaço cênico. As apresentações propiciam uma visibilidade das questões trabalhadas e vividas pelo grupo nos encontros. Saliento ainda, que essa etapa/atividade é bastante estimulante para o grupo, uma vez que mobiliza os participantes a se expressarem publicamente, estimulando-os a um debate social das questões representadas por eles.

As filmagens propiciaram uma riqueza de informações. Foram registrados em vídeo, sete dos doze encontros, e a apresentação teatral que ocorreu por ocasião do encerramento das bolsas de aprimoramento. Neste estudo não realizei as análises dos aspectos não-verbais que estão contidos nos encontros, apenas são transcritos os mais relevantes, que estão disponíveis no ANEXO 1.

O processo da transcrição das fitas de vídeo foi realizado com o auxílio de uma colaboradora e terapeuta ocupacional que atua na área gerontológica. Ao trancrevê-las foi possivel adentrar no mundo vida das participantes, uma vez que, neste processo, é preciso ouvir diversas vezes a mesma fala para poder identificar e transcrever seu conteúdo, que ficou retido com muita intensidade na memória, fato esse, que auxiliou nas análises realizadas.

A coleta de dados foi concluída quando observou-se as repetições nos discursos das pessoas do grupo estudado em relação à questão norteadora apresentada. Expressões como: "de novo!”, "eu não tenho mais o que dizer!", "outra vez a mesma pergunta!" e atitudes corporais de recolhimento ou mesmo de ficar de pé e ir dar uma "voltinha", foram consideradas como ponto de conclusão deste processo. 


\subsubsection{A orientação metodológica}

Para a análise dos dados utilizou-se as orientações de MARTINS e BICUDO (1994) de análise fenomenológica, através da Análise Qualitativa do Fenômeno Situado. Nesta modalidade de investigação, o objetivo é buscar a essência ou estrutura do fenômeno que se mostra nos discursos dos sujeitos, neste caso nos discursos das idosas.

Segundo esses autores, é necessário ao pesquisador que busca des-velar a constituição do cotidiano, situar-se diante do fenômenos a serem investigados de forma que esses possam mostrar-se na sua própria linguagem. Para tanto é necessário despojar-se de pressupostos teóricos e de teorias da realidade. Ao recusar os conceitos previamente concebidos, porém, não se parte de um marco zero, isso não quer dizer que ao adotar essa metodologia não se tenha uma postura prévia em relação ao que se estuda. Como afirmam:

"quando um pesquisador, proveniente de qualquer orientação em pesquisa, põe-se a interrogar sistematicamente um fenômeno, ele já está sendo dirigido pelo que compreende como estando ali para ser pesquisado"(op.cit. p.77).

Ao se adotar uma postura fenomenológica baseada nessa modalidade esperase que os sujeitos pesquisados sejam capazes de descrever o que estão experienciando de um modo mais adequado do que o pesquisador poderia fazer.

As percepções que estes têm de sua experiência vivida constituem-se em dados de pesquisa ou unidades de significado. Os fenômenos são agrupados por semelhanças ou diferenças fundamentais de acordo com as essências descritas buscando-se as convergências ou o aspecto comum.

Para a análise das descrições, destacam-se quatro momentos reflexivos:

- primeiramente faz-se a leitura das descrições adotando-se uma postura o mais neutra possível, buscando não interpretar o que está exposto e sim, compreender a linguagem dos sujeitos. A partir do princípio da intersubjetividade 
que está presente na relação empática que foi estabelecida, compreendendo que a dialética pesquisador-sujeito pode ser compartilhada e repetida.

- Em um segundo momento, busca-se identificar as unidades de significado, após ler e reler (neste caso também assistir às filmagens dos encontros realizados) os depoimentos quantas vezes forem necessárias, destacando do próprio texto (e das filmagens) as discriminações espontaneamente percebidas nas descrições das pessoas que focalizam o fenômeno que está sendo investigado. Estas unidades, porém, de acordo com os autores, não estão prontas no texto, mas existem em relação à atitude, disposição e perspectiva do pesquisador. Neste sentido os autores complementam:

"o pesquisador utiliza sua própria experiência assim como aquela que os outros têm do fenômeno estudado, para levar a uma inteligibilidade cada vez mais articulada a sua própria concepção, evoluindo pessoalmente para chegar à experiência semi-articulada do sujeito pesquisado"(op.cit. p.78).

- No terceiro momento, transforma-se as expressões cotidianas dos sujeitos em uma linguagem psicológica utilizando um procedimento reflexivo, agrupando-as em unidades temáticas para finalmente fazer-se uma sintese de todas as unidades de significado, chegando a uma descrição consistente da estrutura do fenômeno.

Neste sentido, para esses autores o compreender:

"é uma expressão imediata daquilo que o ser humano sente na presença do objeto e é um reconhecimento que as coisas são o que a sua natureza exige que elas sejam"(op.cit., p.90).

Ao buscar informações a respeito de pesquisas qualitativas na área gerontológica, localiza-se uma quantidade bastante reduzida de trabalhos cientificos e ao buscar pelos de orientação fenomenológica que contemplem especificamente o significado do envelhecer, no âmbito nacional, foi encontrada somente uma tese de 
doutorado que busca o significado da atividade física para o idoso de orientação fenomenológica.

No entanto, as investigações de orientação fenomenológica na área da saúde como um todo, tem ganhado destaque, principalmente teses e dissertações de enfermeiros, psicólogos, educadores, sanitaristas, médicos. Entre muitos pesquisadores destaco: Boemer (1985), Rainer, Mendes (1987), Forghieri (1988), Valle (1988), Alencastre (1990), Andrade (1992), Castro (1990), Arantes (1991), Andrade (1993), Souza (1993), Cadete (1994), Monteiro (1996), Oliveira (1996), Sumire (1997), Pereira (2000), Fernandes (2000), Corrêa (2000), Melo (2003).

No próximo capítulo busco descrever e refletir como essa manifestação de subjetividade dos idosos em relação ao seu envelhecer apresentou-se a mim, conforme a metodologia adotada no presente trabalho. 


\title{
Capitulo 6
}

\section{BUSCANDO O SIGNIFICADO DO ENVELHECER}

\author{
Mudo-me breve \\ "Recobro espuma e nuvem \\ E areia frágil e definitiva. \\ Dispõem de mim o céu e a terra, \\ Para que minha alma insolivel \\ Sozinha apenas viva. \\ Naquelas cores de miragem \\ Da água e do céu, mais me \\ compreendo. \\ Anjo instrutor em silêncio me leva: \\ E elas fazem ver que sou e não sou, \\ no que estou sendo."
}

Cecilia Meireles. 


\section{Capítulo 6}

\section{BUSCANDO O SIGNIFICADO DO ENVELHECER}

Como ser vivo, o homem está sujeito às fases de crescimento, maturação, envelhecimento e morte. Neste desenrolar da vida, que se apresenta por um acúmulo de idades, há um evento progressivo, onde o homem por mais avançada que seja a idade, se encontra. $\mathrm{O}$ envelhecer compreendido numa abordagem existencial, é visto também como um revelar de possibilidades, pois assim é concebido o homem. A vida não se conclui com a seqüência das idades, mas as atravessa (JASPERS 1985).

A pessoa que envelhece, está indo na direção do seu próprio caminhar, aproximando-se de suas particularidades e afastando-se de certos modos próprios de ser, indo ao encontro dos outros e das coisas que o cercam. Esse caminhar acontece no encobrir e descobrir de possibilidades próprias do existir.

$\mathrm{Na}$ fase da vida denominada velhice o homem, embora apresente os atributos biológicos de um corpo envelhecido, pode estar ainda começando, empreendendo.

A velhice pode ser vista e medida por um tempo cronológico, mas será que ela é sentida? Se for sentida, como ela é sentida?

Nas relações sociais a pessoa que possui uma aparência que o identifica enquanto velho vivencia algumas ambigüidades. Uma delas diz respeito aos valores sócio-culturais que determinam quem é velho, que também foram construídos, senão aceitos, por ele. Outra ambiguidade diz respeito ao homem enquanto um ser de infinitas possibilidades, uma pre-sença lançada no mundo que não encontra nessa demarcação social uma medida que determine o quão velho ele é. Ser visto e identificado como velho, não satisfaz a subjetividade humana de existir em um tempo, enquanto existência. Enquanto um projeto o homem não tem idade.

Enquanto um ser social ele está inserido em uma intrincada rede de relações em que os papéis relacionados às fases da vida the são impostos. As alterações orgânicas sentidas podem facilitar a sua identificação social de velho. Para que esse sistema de datação, geracional e de papéis sociais relacionados à produtividade seja mantido, é preciso existirem os velhos. A assimilação do que seja velho, para quem está com uma "idade da velhice", se faz necessária pela sociedade. 
A aposentadoria é o exemplo mais significativo de condição social que primeiro demarca essa fronteira entre juventude e velhice.

$\mathrm{O}$ homem enquanto ser-no-mundo vivencia essas realidades. $\mathrm{O}$ significado subjetivo do seu próprio processo de envelhecimento, sentido em todas as suas particularidades e vivido em suas infinitas possibilidades humanas, decortina-se como uma questão a ser investigada.

Assim o existir desse envelhecente só pode ser sentido como uma totalidade, um entrelaçamento de fios significativos permeados por sentidos diversos. $O$ homem tem sempre consciência de si mesmo, ultrapassando qualquer conhecimento que adquira de si. De acordo com JASPERS (1985):

“quando investigamos o homem, não somos apenas espectadores de alguma coisa que nos é estranha, mas seres humanos mesmos. Somos nós próprios que investigamos, quando investigamos o outro. Não interessa somente saber de umas tantas coisas, mas o fato é que só sabemos pelo nosso próprio existir humano"(p. 918).

Através das descrições das envelhecentes é permitido um acesso ao seu mundo-vida. A partir da minha própria experiência sobre o significado do envelhecer busco compreender eideticamente o significado do envelhecer para elas.

Apresento neste capítulo, as análises das descrições segundo a Análise Qualitativa do Fenômeno Situado.

Destaquei em cada transcrição relacionada aos discursos das idosas motivados pela questão norteadora, os trechos que se mostraram significativos, denominados e agrupados em "unidades de significado". A seguir, apresento uma sintese destas:

- O envelhecer estando relacionado às transformações corporais;

- O envelhecer sendo um processo natural do ciclo da vida;

- O envelhecer em um tempo cronológico;

- A velhice estando relacionada com perdas, doenças, angiistias e preocupações;

- Assumindo ou não a velhice e a morte; 
- O envelhecer enquanto renovação, libertação e possibilidades;

- O envelhecer estando em atividade grupal, divertindo-se, tendo planos futuros $e$ cuidando-se;

- O envelhecer de si e o envelhecer do outro;

- O envelhecer e a importôncia da familia e da sociedade;

- Ambigüidades em relação a ser e sentir-se envelhecendo.

A partir desta categorização, procedeu-se a análise compreensiva dos discursos em cada unidade temática destacada, buscando-se encontrar nestas, os desvelamentos que convergiram ao fenômeno buscado.

\subsection{As unidades temáticas - relatando os encontros}

\subsubsection{O envelhecer estando relacionado às transformações corporais}

Com o envelhecimento, são explícitas as transformações relacionadas ao corpo. No conjunto dos discursos expressados apareceram, em um primeiro momento, considerações mais generalistas em relação à essas transformações, frutos de preconceitos, de modelos apreendidos pelo padrão cultural e social. RODRIGUES (2000), a esse respeito, coloca que as características físicas, corporais, são as primeiras a serem relatadas pelos idosos como sinais de velhice. Principalmente nos primeiros encontros, as falas dizem respeito às mudanças externas, corporais:

NM: a pele vai ficando áspera, enrugando (passando as mãos pelo rosto e perna) $\dot{E}$ isso! Todo mundo fala: "É velhice!" É velhice. (....) Mas, o envelhecimento é o corpo mesmo.

JP: Mas a velhice tá no corpo, a gente vai enrugando, né?

LTB: (colocando as màos no corpo) você vai engordando aqui, caindo aqui é pelanca em todo lugar...

A relação com o corpo surge como uma relação com um corpo-objeto, o corpo-de-que-se-fala. As alterações na imagem corporal são identificadas pelo outro, 
pela sociedade e por si, como sinais de envelhecimento, reconhecidas como transformações naturais. Foi possível perceber também que a velhice "reconhecida" acontece somente no corpo, é o "corpo" que envelhece.

De acordo com SANTIN (1993livro corporeidae etercidade):

“A imagem do corpo não surge das experiências existenciais da vida pessoal, ao contrário, a primeira imagem consciente de corpo que cada um constrói, obedece aos modelos impostos pelos valores culturais vigentes" (p.53).

Por outro lado, alguns depoimentos trazem uma assimilação valorativa a respeito dessas transformações corporais, suscitando uma rejeição desse corpo envelhecido, valorizando o corpo do passado:

OMS: Eu tô feia, tô ficando véia com o cabelo meio branquiado já. Tô ficando gorda agora.

TS: ter o cabelo branco (....) O corpo já não é aquele corpinho mais ajeitadinho, a carne já secou um pouco, enrugada, você pode se arrumar mas nunca mais volta aquela coisa.

O envelhecimento aparece aqui ainda externalizado, no que é visivel, no corpo que é visto, concebido, julgado. Segundo as afirmações de BERG (1981):

"o corpo que temos é diferente do corpo que somos. (....) Alguma distância tem que ser estabelecida, embora pequena, entre nós e o nosso corpo, antes de podermos dizer que temos um corpo. Falar do seu próprio corpo significa falar de si mesmo" (p.52).

No sentido da identidade social que esse corpo assume, como fazendo parte de um esquema de valores e crenças, MONTEIRO (2001) afirma:

"quando a aparência fisica demuncia aos outros os aspectos referentes $\grave{a}$ velhice, como cabelos brancos, rugas, atitudes corporais, associada aos conhecidos atributos negativos, o velho sente a força do conflito. Há um descompasso entre sua 
imagem do corpo - aquilo que ele acredita ser ele mesmo - e o corpo fisico - aquilo que os outros vêem como sendo um corpo de velho"(p.112).

Em um outro momento, o discurso foi caminhando "corpo a dentro", passando a descrever as alterações corporais que trazem prejuízos em algum tipo de desempenho físico, orgânico, o corpo-de-que-se-fala não é só o corpo-que-é-visto, é também o que sente, o que vive, independentemente do que se sente em relação a isso. Neste momento, o envelhecimento aparece no corpo no sentido de perdas:

JP: É o corpo que vai cansando, a carne vai cansando...

EB: As pernas vão ficando fraca...

IC: É, o cérebro da gente que fica cansado, né?

Em outros depoimentos, as alterações corporais, orgânicas, passam a ser incorporadas na experiência dos sentidos: o corpo-que-eu-tenho é o corpo-que-eusou. Há uma interiorização das transformações corporais vivenciada em perdas, indicando como estas afetam suas vidas de uma forma não somente estética mas sentida como envelhecimento, nos seus aspectos negativos, expressas como definitivas. Envelhecer significa perder. O reconhecimento dessas perdas é traduzido em tristeza, em uma negação do porvir, se esse porvir estiver associado a mais perdas e limitações. Transparecendo um sentimento de fracasso, de perda de controle sobre o próprio corpo:

EE: Ahh Credo!! Não consigo mais subir em um banco. Ihh! Estou ficando véia. Eu que subia em goiabeira, haranjeira, hoje não consigo subir em um banco. Fico muito triste de não conseguir. Envelhecer é muito triste. Não quero envelhecer. Quero ir como eu estou indo.

EB: Envelhecer é muito ruim. Queria ficar sempre nova. Nāo queira envelhecer. As pernas vão ficando fraca.

Neste sentido, de acordo com Merleau-Ponty, a mudança na concepção de imagem corporal refere que o "corpo vivido" deve estar ligado ao "estar sempre experienciado". A mudança na concepção de imagem corporal implica uma transformação do corpo objeto para o corpo experienciado, dotado de 
intencionalidade encarnada, de propósito do corpo global (MARTINS e BICUDO 1997, p.71).

"somos sujeitos com um corpo que não está hermeticamente selado, mas com uma intencionalidade relacionada com o mundo. A descoberta da subjetividade encarnada no corpo leva-nos a revisar nossa concepção de mundo sensível como um todo" (op.cit. p.92).

Outros depoimentos exprimem uma referência ao passado a respeito das características fisicas, evidenciando a beleza feminina, tão valorizada como um atributo essencial à mulher na sociedade moderna e ocidental, destacando os valores de hegemonia do corpo, da estética corporal, da cultuação do corpo.

Estes depoimentos trazem uma insatisfação em relação às mudanças corporais relacionadas a esses valores, experienciadas como negativas no presente. Essas mudanças são assimiladas pela pessoa como uma condição de ser-no-mundo. Envelhecer significa não reconhecer-se mais bela, de acordo com os valores apreendidos cultural e socialmente sendo isso uma facticidade:

JP: Eu queria ficar na idade que eu tinha quando eu tinha 18 anos, eu era tão bonita! (risos) toda hora que eu olho no espelho, ói que diferença, tô gorda, eu era tão bonita!

EE: É não volta! Nunca mais volta aquela menina linda que eu era! Eu era muito linda!

Como refere MONTEIRO (2001):

"Certas pessoas reclamam que seus corpos não inspiram mais nenhum atrativo, sobrando apenas tristeza e lembranças de um tempo de sedução"(p.37).

Em outros depoimentos, a dimensão corporal é transcendida, embora esteja presente enquanto condição de ser-no-mundo. A alusão ao espírito enquanto sede de experiências de eterna vitalidade e juventude, nessas falas, corresponde ao ser enquanto existência que independe de corpo para existir. Negar o corpo e "ficar" no 
espirito, pois este não envelhece, traz a condição de perpetuação da juventude que o corpo perdeu. Há uma dissociação entre a concepção de corpo e espírito, estando este subjugado àquele, mesmo que o corpo ainda surja como uma referência de vida, de expressão, ele é limitado:

NM: Meu espirito deve tá muito bom, tá novo, tá muito mais desperto, “Graças a Deus!" $O$ espírito nāo envelhece, porque o espinito enfraquece, quando o corpo tá fraco. Então, eu não gosto de ficar no corpo, o espínto tem que tá bem. Aí eu acho que meu espirito tá bem, melhor que meu corpo.

MRV: eu sinto bem Graças a Deus, principalmente agora que eu internei e emagreci $10 \mathrm{KG}$, embora eu tô ficando mais enrugada, mas eu não tô nem ai com as rugas, mas meu espírito é outra coisa.

Para Heidegger, o tempo e não o espaço, é a dimensão da realidade da presença. A pre-sença é um ente desprovido de substância, mas que tem uma História.

\subsubsection{O envelhecer sendo um processo natural do ciclo da vida}

Em muitos momentos as falas das participantes traz uma concepção de que o envelhecimento é um processo natural do ciclo da vida, uma facticidade. A vida aparece como uma tarefa que deve ser cumprida com naturalidade e aceitação, com suas realizações e transformações, tanto corporais e mentais, quanto de papéis sociais a serem desempenhados:

MAA: Eu acho que envelhecer... faz parte da vida... é uma vida que ocê já fez aquilo tudo que tinha que fazer quando cra nova... porque todos nós vamos chegar numa idade.

NM: É a natureza da gente, é a cabeça, vai chegando os anos, a carne vai ficando fraca a gente vai cansando... vai passando os anos, csse corpo fica diferente dos 20 anos... cê vai mudando uai!

GS: Assim normal, primeiro a gente é novinha, depois fica adolescente, moça, depois casa, fica mulher, tem os filhos e vai envelhecendo entào a gente vai aceitando, assim é normal.

JP: devagar vai ficando mais velha, a gente vai envelhecendo...

Nesses depoimentos surgem expressas as relações com a temporalidade, com as datações. A medida de um tempo determinado para se realizar coisas, o tempo da 
juventude é o tempo das realizações, da praxis, o tempo da velhice é uma etapa final do ciclo da vida. A vida aparece como um script a cumprir, comum a todos os homens.

Em outras falas, o aceitar as transformações enquanto naturais aparece dissociado do sentir-se velho enquanto uma condição, surgindo nestas uma inconformidade latente, do que seria ser-velho e do que seria envelhecer, enquanto um processo natural, principalmente em contraste com o corpo físico. Os significados expressos são de dissociação do que é percebido e aceito enquanto sinais do envelhecimento e o que é sentido como tal:

TS: Porque tem que ir ficando mesmo, o corpo vai ficando, os anos vão passando...O mês que vêm tem mais um ano prá mim, assim no meu pensamento eu não tô me sentindo véia, agora no meu corpo...

GS: Eu aceito, mas eu não me acho velha! Assim normal, primeiro a gente é novinha, depois fica adolescente, moça, depois casa, fica mulher, tem os filhos e vai envelhecendo então a gente vai aceitando, assim é normal.

A presença da finitude, da morte, contemplada nessa concep̧̧ão do envelhecimento aparece como sendo parte do processo natural, como uma possibilidade, dentre as várias possibilidades do homem enquanto ser-no-mundo:

IC: Velhinha a gente tem que ficar, velha, 67 anos!68! a gente vai ficar velha, mas a gente nảo sabe quando a gente vai embora.

De acordo com HEIDEGGER (2001):

"A finitude do homem consiste no fato de que ele pode experienciar a presença do ente na totalidade, do que já-foi e do que ainda-virá e não em uma presença imediatamente presente como ser em um munc stans."(p.236)

Para Heidegger, a morte pertence à própria estrutura essencial da existência, caminhamos ao encontro da morte, morrendo a cada dia. Como refere FORGHIERI (1984):

"Vivemos e morremos, de certo modo, simultaneamente, pois a cada dia que passa, a nossa existência tanto aumenta, quanto vai se encurtando. No decorrer de 
meu existir caminho, a cada dia, para viver mais plenamente, assim como para morrer mais proximamente" (p. 20).

\subsubsection{O envelhecer em um tempo cronológico}

A velhice está associada ao fator tempo. Quando se pensa em velhice há uma associação imediata a um tempo transcorrido, a um passar pelo tempo, ou que "passou do tempo", velho é o que já foi novo, o que já está próximo do fim. A idéia pré-concebida de que ser velho é "estar passado" aparece nas falas de uma maneira distinta entre o que se pensa a respeito da quantidade de anos determinar a condição de ser velho e o que é vivenciado enquanto experiência, enquanto vivência.

Alguns depoimentos revelam que, apesar de algumas das participantes apresentarem uma idade avançada em relação ao que se convenciona socialmente de chegada na velhice e aceitarem esta premissa como verdadeira, não se identificam com este "estado de ser-velha". Aparecendo duas concepções de velhice: a datada, que tem sua representatividade enquanto uma demarcação de velhice, e a sentida que traz a concepção de que ter uma idade avançada, não significa ser velho, onde a idade não aparece como limitante, nem como determinante da velhice. $O$ tempo de vida acumulado quando está associado à vitalidade e à preservação das capacidades físicas e mentais comparece como um prêmio conquistado:

NM: Não tem nada a ver a idade, porque eu tenho 74 anos! Eu tenho ânimo prá fazer tudo, se eu fosse velha eu não fazia tudo o que eu faço!... Nóis só somo véia na idade!...A idade não tem nada à ver! A idade não é véia!

EE: Ela tem 75 anos e tenho 74 ela tem 1 ano a mais que eu, olha como nos somos prá frente, nenhuma de nóis é véia!

TS: Vou envelhecer lá pela casa dos 80 . porque tem uns de 60 e 70 que tá bem mais esperto, tem muita gente de 70 anos que tá bem esperta!

MCS: Tem uns velhos de 83 anos lá no baile que dança com gente, dança com a gente que nem um trem, mas dança! Vai tanto homem como mulher, mas dança, a gente fica de boca aberta de ver eles dançar!

A classificação da vida feita a partir de um tempo cronológico, parece ser uma necessidade antes da estrutura social do que individual, o tempo do relógio, do calendário, as faixas etárias enquanto determinantes de condições de ser, são antes 
convenções, que orientam o funcionamento de uma sociedade e de seus indivíduos, em termos de temporalidade. Mas este conceito é muito mais amplo quando se parte da noção subjetiva de tempo, do próprio tempo. Como refere HEIDEGGER (2002):

"A relação com o tempo que temos não é nenhuma relação ligeira, dimimuta, mas sim justamente é a que sustenta nossa morada no mundo. O tempo que temos e não temos, sacrificamos ou desperdiçamos é aquilo que de certa forma dispomos, que podemos dividir ou organizar de uma ou de outra forma..." (p. 215).

As falas também expressam uma aceitação, embora parcial desta cronologia que apresenta-se como uma facticidade do porvir ao mesmo tempo que sugere a negação do que será este porvir, impondo condições a ele (o porvir):

JP: Eu tô com 75, eu sei que é muito, se eu não amolar ninguém eu queria viver até uns 100 anos, mas com saúde, eu queria viver bastante.

EB: Lá pelos 80 , eu vou sentir. No final dos 80 já vou me sentir (velha).

TS: Eu também, lá pelos 80 é que eu vou sentir, agora eu não posso sentir, não quero!

\subsubsection{A velhice estando relacionada com perdas, doenças, angústia e preocupações}

A enfermidade e o medo da morte aparecem sendo fatores psicossociais pertinentes a maciça maioria dos idosos. Doenças crônicas e degenerativas, a presença da dor, e outras dificuldades geralmente vêm acompanhadas de medo e humilhação.

Em alguns depoimentos, as participantes expressam uma grande preocupação em relação às conseqüências negativas que aparecem com o envelhecer. As doenças comparecem como inimigas e participantes do processo do envelhecer, que surge como uma etapa de sofrimentos, de preocupações, de pesares quando está associado às doenças. Quando vista por esse ângulo a velhice é quase um sinônimo de doença, de loucura e de sofrimento:

EE: Envelhecer é a doença...

MLF: Velhice é as pessoas caducando... 
OMS: Sofrimento inimigo da velhice sāo as doenças cardiovascular (...) Ah! Muito cansaço e preocupação na minha vida, preocupação e cansaço na minha vida, só isso!

IC: Eu acho que todas as pessoas que fica de mais idade, ficam cheias de manias.

JP: É ter muita preocupação, tem que ficá pensando em médico, pensando na vida, pensa em um, pensa em outro, daí vai envelhecendo e pronto!

MRV: Eu penso que quando a gente vai ficando mais velha, a gente fica doente.(...) velhice é tristeza.

TS: É porque a gente já ficou enfraquecida, já envelheceu. Eu vou ficar uma véia bem impertinente, ishi! eu vou ficar uma véia bem ranzinza! Envelhecer é ser muito teimosa. Viver contrariada com tudo, a tristeza.

A velhice está associada à perdas, à decrepitude, à desajustes. Os prazeres da vida estão muito mais relacionados, segundo o senso comum, à juventude. $O$ sentimento de que vai se perder algo valioso com a velhice é presente:

TS: Depois que a gente vai pegando certas idade, acaba uma dança, acaba um olhar, acaba um namoro, a gente gosta de olhar? A gente fica mais velho, isso acaba, não tem mais aquela influência de paquerar, de dançar.

IC: Quando a gente vai ficando velho... já perdi muita coisa!

NM: Envelhecer é quando não puder mais andar e trabalhar.

Os medos e as angústias aparecem como uma preocupação, como incerteza do porvir, como a necessidade de depender de terceiros:

MCS: Eu tenho medo de ficar doente, de precisar de alguém para tomar conta de mim, é só isso que eu penso.

OMS: ai,ai,ai, não sei o que vou falar...Quando eu ficar velha, eu tenho medo de sofrer por que a gente fica doente e precisa de alguém olhando a gente, só isso.

$\mathrm{Na}$ presença da dependência como algo possível a ser vivenciado na "velhice avançada", a reclusão, na forma da institucionalização, aparece como uma possibilidade: 
MLF: Eu penso assim: eu não quero ficar numa cama dando trabalho, precisar dos outros me olhando, velando de mim. Oh! e tem uma coisa: se eu ficar bem velhinha, assim, não agüentar mais, melhor eu procurar um asilo prá lá, e vou ficar por lá, sabe?

JP: Isso eu também quero: quando eu ficar bem velhinha não quero ficar amolando ninguém. Quando eu vejo que já tá na hora de vir a idade não quero aborrecer ninguém...

No seguinte depoimento houve uma reflexão acerca da vida e do envelhecer enquanto um produto de como se vive essa vida. A possibilidade de torná-la boa ou ruim, de acordo com a infinidade de possibilidades que o homem é. $\mathrm{Na}$ intersubjetividade que se faz presente neste homem em seu estar-com-outro-nomundo, vislumbrando no outro as sua próprias possibilidades, na velhice, pode surgir como uma fatalidade num movimento de queda:

TS: Eu fui chamada na água-minas fazer uma consulta lá, tava esperando chamar e tinha um casal de velhos, eu fiquei olhando e pensando: ele era gordo, ela pegada no braço dele...Eles vindo devagar. Eu juro por Deus me deu uma tristeza, me deu uma angústia! Ai meu Deus, como a gente vai embolando a vida da gente! Ai meu Deus, essa manqueira na perna dele, gordo, já velho, aquilo parece que foi puxando as coisas de mim para fora! Olha até onde a gente chega! Cheguei em casa me deu vontade de chorar fiquei tão caladinha assim ...

Heidegger afirma que o homem é um ser-no-mundo, inseguro e angustiado, existindo sempre com preocupação. A angústia revela a essencial impossibilidade de determinação.

O medo como a negação da velhice, do envelhecer, da realidade enquanto uma realidade de possibilidades nefastas, pelo reconhecimento de que envelhecer é sinônimo de perdas e limitações, aparece expresso nas falas das participantes:

EB: É horrivel, é horrivel ser velha...Eu não aceito envelhecer. vai ficando ruim né?! Trapo. Eu sei que agüentava subir uma escada e não agüento subir, vai acabando a resistência, vai acabando as forças, eu por mim nào queria ficar velha nunca, estacionava agora.

IC: Eu não queria ficar velha, não! 


\subsubsection{Assumindo ou não a velhice e a morte}

As diversas formas de envelhecer estão relacionadas com as diversas formas de viver. $O$ envelhecer acontece, assim como o morrer, desde que se nasce, a presença é um ser para a vida e para a morte, dentro deste caminho está o seu envelhecer.

Viver a própria vida, com intencionalidade, passa a ser a grande aventura humana ou seu grande desafio. Neste sentido, RIBEIRO (1985) refere:

“Conhecer a si próprio é experimentar o próprio poder e os próprios limites; é a partir de si próprio que o homem caminha para compreender o mundo e utilizar o mundo na compreensão de si próprio" (p. 28).

Nas falas da maioria das participantes encontra-se uma alusão ao direcionamento que se pode dar à vida e ao próprio envelhecer, através de atitudes intencionais.

É possível também observar uma tendência em negar a realidade do envelhecer através do não pensamento, intencionalmente:

MRV: Eu não fico assim na idéia, por que envelhecer a gente vai mesmo, não adianta ficar pensando.

MA: Envelhecer está na cabeça... Eu não penso em envelhecer

GS: Sei lá, a velhice acho que é aceitar, se você não aceitar a velhice, se você não aceitar, envelhece mesmo...

TS: A gente não pode é pensar na velhice A gente nào pode ficar falando da velhice, se a gente ficar falando que tá velho, tá velho, a gente fica velho mesmo. Então cê tem que esquecer dela, fazê de conta que não existe velhice. Tem que ficar numa boa.

LTB: Eu acho que tá tudo na cabeça. A pessoa que põe na cabeça eu tô doente, eu tô véia, é assim que vai acontecer. É tudo da cabeça!

TSS: Não pensar na velhice!

MLF: Bom, ficar velha nós tamos ficando mas só que nós não pode se entregar, $\mathrm{A}$ gente vai envelhecer não! Mas a gente não pode pôr muito na cabeça não, ficar assim 
muito preocupada nessa vida, senão vai mais depressa, mais depressa... (inclinando o corpo para frente)

NMS: Ah!Eu não tenho tempo de pensar, a hora que chegar chegou. Eu acho que vou viver pouco por isso não penso na velhice.

Essas falas revelam um significado de contato consigo, de forma consciente, num movimento de apropriação de si. Todas as concepções culturais são postas em dúvida ou descartadas. Somos nós mesmos que escolhemos nosso destino.

De acordo com Heidegger:

"o ser-aí é aquele que existe por si mesmo como possibilidade, como fonte de infinitas possibilidades, como seleção realizada dentro de possibilidades particulares no passado e uma seleção de possibilidades particulares realizareis no futuro"(p.234).

$\mathrm{Na}$ mesma direção, o não pensar parece estar associado à proteção de dor e de medo. Assim a velhice aparece sentida como uma entidade, algo que está no pensamento, que pode ser controlada ou pelo menos postergada. A morte, embora não possa ser evitada enquanto um acontecimento, pode ser "esquecida", retirada dos pensamentos:

IC: Num pensar na morte!

IC: Não pensar que vai morrer amanhã! Se pensar é que a morte vem mais depressa! Eu não penso na doença, eu tenho muito problema. Eu penso que eu quero viver.

EB: Eu também não alembro nem da morte, nem da velhice.A única coisa que me apavora é a morte! Tenho horror de morrer. Não quero morrer de jeito nenhum, só isso!

GS: Prá mim a velhice é ficá aceitando, esperando a morte.

A respeito disto, HEIDEGGER (2001) afirma:

"Recordar é tornar presente algo que passou como alguma coisa experienciada por mim há um certo tempo (...) quando se vê o esquecimento na base de um ocultar, de um ocultar atrás de um véu, então este tornar presente é um 
aparecer do oculto (...) Em grego, todo esquecer é um ficar oculto para mim, em minha relação com algo" (p. 114).

Então o que é expressado, nessa intencionalidade em esquecer a velhice e a morte, é experienciado por elas como desafiador, como doloroso. É possivel captar que esse ocultar permite viver a vida de uma maneira mais "positiva" para muitas outras possibilidades. Como se fosse possivel escolher entre ser ou não ser. De qualquer maneira o "não-pensar" parece a atitude adotada para proteger-se da dor e do medo.

Estas possibilidades, em detrimento do sofrimento, aparecem em outras falas:

MLF: Eu pensava, agora eu não penso mais, se vou ficar velha. Eu gosto de me aprontar, de passear. De primeiro, eu fazia aniversário, eu falava que tava ficando velha, que eu ia morrer logo! Agora não, quando eu faço aniversário eu fico contente. Eu sou de mês de maio. De primeiro eu tinha medo...

MCS: Acho que preocupaçāo né!? Esses dias eu tava me achando meio decaída, assim né?! Daí eu disse: preciso dar um jeito nesse rosto. Ai eu passei um batom, arrumei meu cabelo...Daí minha menina falou assim: “ a minha mãe não anda boa de jeito nenhum, ainda bem que a minha mãe passou um batom”...

No decorrer dos encontros as colocações sobre o significado do envelhecer apresentaram uma faceta de aspectos positivos relacionados a essa fase da vida. Além dos medos as possibilidades se descortinavam, o que levou à próxima unidade temática.

\subsection{6 $O$ envelhecer enquanto renovação, libertação e possibilidades}

Em seus depoimentos as participantes foram expressando suas vivências e experiências relacionadas ao envelhecer feliz, muitas vezes mais feliz que a própria juventude. Alguns depoimentos foram realizados após uma vivência de teatro espontâneo do cotidiano e aparecem carregadas de emoção, de desabafo, de descobertas:

NM: Eu acho que 2 anos atrás eu tava mais velha que agora. 
TSS: Eu já fui velha, mandei ela tudo prá trás, já faz 9 anos eu tô me sentindo jovem.

EB: Eu tenho certeza que eu vou ser uma véia bem legal, bem prá frente!

TS: Porque na época era um tal de sofrimento, cuidar de filhos, marido nāo gostava de passear, era aquela "clamidade" de tudo, um dia você tinha uma roupinha outro dia cê não tinha um calçado, e vivia aquela "vida chutada" aconteceu tudo, ele morreu, eu fiquei com meus filhos, tudo solteiro ainda, só tinha um casado e eu fui cada dia me desgastando, cada dia me desgastando, ai levei uns 2 anos ainda esse desgaste na minha vida, andava prá rua chorando, encontrava um tava chorando, encontrava outro dizia que eu tava demolindo minha vida, aí uma amiga minha falou prá mim assim: "vai procurar a ginástica, você vai, fica lá, vai sará dessas coisinhas", aí vim, achei esse negócio aqui, fiquei, tô aqui hoje graças a Deus! Aí eu fui me levantando, levantando e graças a Deus, hoje eu acho bem eu "no ar", me sinto mais cheia de força, cheia de alegria, não tenho mais aquela tristeza que eu sentia, antes, né, eu sofri bastante, muito mesmo! E hoje graças a Deus, por isso é que eu falo, eu já fui véia lá no passado, lá prá trás, hoje eu tô me sentindo uma pessoa realizada das força que eu tenho hoje, graças a Deus.

MCS: Agora é que eu acho que tô vivendo... também agora, eu não sou velha! No tempo que eu era moça mesmo, não aproveitei nada, nada... agora não, agora eu tô aproveitando a minha vida, tô fazendo tudo aquilo que eu não fiz... eu me sinto tão feliz' Eu vou dançar, agora, vou namorar, precisa ver o que eu arrumo agora, no meio dos amigos lá no baile. Agora eu tenho amigos prá poder rir, prá poder viver. a gente conversa muito, a gente dança, porque eu sei que agora, eu dei um passo na minha vida, tão melhor agora, precisa de ver que delícia!"

MLF: Gostei das brincadeiras, da ginástica, do cobrador de ônibus. Envelhecer é se entregar, se abandonar, é não se aprontar, não se divertir. Eu não fazia isto. Eu ficava muito triste, estava entrando em depressão. Hoje já estou bem melhor. Fui até para Santos passear com minhas amigas aqui do grupo da terceira idade. Gostei muito das brincadeiras. Lembro das brincadeiras e fico cantando. Pensei que fosse muito difícil. Pensei comigo: Será que eu vou passar vergonha!

A esse respeito, sabe-se que, para muitas mulheres ocidentais que hoje apresentam mais de cinqüenta anos e portanto nasceram em meados do século $\mathrm{XX}$ ou antes, os papéis femininos eram ainda bastante demarcados por regras sociais orientadas pelo regime patriarcal. Estes papéis incluíam o lidar com a casa, o cuidado com os filhos, o cuidado prestativo, deveres e o respeito com o marido. Este em contrapartida assumia o papel de liderança e de provedor do lar. As mulheres em geral, principalmente as de condições sócio-econômicas mais desfavorecidas, tinham poucas oportunidades para estudarem ou seguirem uma profissão fora do espaço doméstico e viviam sob a guarda dos pais e a seguir dos maridos. A liberdade era restrita, o trabalho e o cuidado com a casa e com os filhos, ocupava boa parte da 
vida. Essas mulheres hoje, com mais de cinqüenta anos, experimentam atualmente uma liberação em termos de regras sociais. Como refere DEBERT (1999):

"para as mulheres, o envelhecimento significa uma passagem de um mundo totalmente regrado para outro em que se sentem impelidas a criar as próprias regras (...) Liberdade e independência são valores positivamente qualificados que dão à vida cotidiana uma nova dimensão de bem-estar. O bem-estar é construido através da oposição entre a liberdade atual e as outras etapas da vida, sobretudo a juventude, em que as mulheres eram vítimas da opressão dos pais e dos controles que a sociedade exercia sobre ela" (p.185).

Para as mulheres dessa geração a possibilidades de viverem mais para si só acontece na velhice, após terem desempenhado seu papel junto ao marido e aos filhos e em muitos casos, os netos também. À mulher é designado o papel de cuidadora.

"Existir é estar em constante processo indo sempre adiante, caminhando para um futuro que se abre diante de nós, com possibilidades imprevisiveis e incontroláveis, é por isso que precisamos ter coragem para existir, coragem para ser" FORGHIERI (1984 p.19).

\subsection{7 $O$ envelhecer estando em atividade grupal, divertindo-se, tendo planos futuros e cuidando-se}

O autocuidado aparece como uma ação básica do ser humano. A partir do grau de autocuidado de uma pessoa, pode-se ter uma idéia de como está sua autoestima. Ele permeia o cotidiano. Está carregado de significações e traduz o próprio Eigenwelt, que compreende as relações pessoais do indivíduo consigo mesmo, ele pressupõe auto-consciência e auto-relação e é exclusivo do ser humano. No mesmo plano de prioridades acontece o Mitwelt, que designa, o mundo das relações entre os homens. 
Nos depoimentos, essa relação consigo, este Eigenwelt, e as relações com os outros, o Mitwelt, traz como importantes as atividades prazerosas na velhice, como determinantes de bem-estar, em contraposição à velhice:

MA: Velhice é nāo se arrumar, não se cuidar. Depois que eu vim para a ginástica eu melhorei muito. Aqui tenho este pessoal como minhas irmās. Gostei muito do que vocês fizeram.

NM: Eu não me sinto véia, mas não sei o que os outros acham de mim. Não me sinto véia, pois até brincamos de roda hoje. $\mathrm{E}$ é depois dos quarenta que a mulher é mais mulher Não me sinto veia pois vou alcançar ter um tataraneto.

OMS: Um dia nós vamos ficar velhos, e nós precisamos aproveitar bastante a vida até quando velhos. Ir à ginástica, baile, passear com os amigos, a familia faz parte da nossa vida, com o apoio dos filhos, assim, podemos suportar a tristeza, a alegria, a a dor, e o medo.

LTB: Faço ginástica tenho meus amigos, vou batendo a asa, eu vô, faço a festa, eu danço, eu faço ginástica dentro da água, (risos) aí acabô (abaixa o tom de voz) aquelas coisa de ficá assim, a gente se acabando, cheio de problema, então eu acho que tem mais é que se divertir.

TS: Eu gosto de andar bem arrumadinha, hoje eu me sinto mais realizada nas coisa, eu sinto, que nem agora eu tô velha, mas não me sinto velha!

MRV: Tá! Meu espírito tá jovinho, tem gente que fica preocupada, cê tá emagrecendo, pensando que eu tô mal, tem roupa que tava guardada há seis anos, agora eu tô usando de novo a roupa não servia faltava um palmo, agora é que eu tô feliz, eu tô fazendo ginástica, caminhando, tô fazendo direitinho meus trabalhos, minhas consultas.

GS: Gosto dos meus cabelos brancos (passando as māos no cabelo), gosto de teatro, gostei de dançar, tô contente aqui. GS: Não me sinto veia. Gosto de dançar, brincar, passear. Não reclamo de dor. Aonde me chamam eu vou. Adorei a brincadeira de roda. Me senti criança.

JP: Não me sinto velha, não! Me sinto ainda com um pouquinho de coragem, ainda, gosto de conversar, passear é comigo mesma, eu não sou muito de conversar, mas passear, eu vou em tudo que é passeio, isso eu acho que tô podendo ainda.

LTB: Ter sempre aquela idéin de jovem, viver a vida, tem que passear, viver, brincar, tudo o que não viveu prá trás vai vivendo prá frente. Eu participo em tudo eu venho na ginástica, eu vou na Igreja, eu onde me chamam eu vou. Eu acordo cedo às $7 \mathrm{da}$ manhã, fico acordada até meia-noite, sô tão animada eu não me sinto velha

MAA: na minha idade, esses passeio, essas coisa que vocês faz prá gente, essas menina que tá sempre arrumando passeio, fazendo as coisa, eu acho muito bão, na minha idade, na idade que nós tamos aqui. Admiro muito essas que tem mais idade que eu, que fíca sempre ali, eu não sei se a Dona GS, e a MCS são da minha idade, mas elas fazem ginastica 
Observa-se que a velhice ou o "estar velha" parece estar relacionado à inatividade, falta de prazer e autocuidado. Assim, as atividades que as participantes estão realizando no presente, a ginástica, os grupos em geral, parecem ter, em grande medida, estimulado seu autocuidado e sua auto-estima. Assim como o sentir-se velha está relacionada a um estado negativo, de inatividade, de falta de autocuidado, de auto-abandono. A inserção no grupo parece ter permitido uma modificação; o bemestar que estas atividades têm lhes proporcionado como seres-no-mundo em relação ao Eigenwelt e ao Mitwelt, está expresso e relacionado com os encontros, com as trocas com o outro, com o grupo e com a liberdade de poderem neste tempo da vida, se expressarem e realizarem seu autocuidado com mais exclusividade. A velhice passa a ser uma entidade afastada dessas possibilidades, pois ela, ainda carregada de preconceitos e senso comum de limitações, sofrimentos e doenças, torna-se distante quando comparada aos ganhos que a vida está lhes proporcionando neste momento de valorização pessoal.

De acordo com BOTH (2000):

"a necessidade de um sentido na vida permanece independentemente da idade, e seu atendimento é normalmente construido em formas de inserção social reconhecidas pelos outros" (p.74).

A importância do grupo da terceira idade é uma constante nas falas, mostrando o quanto de significações ele pode ter nesta fase da vida, como se formasse um elo, uma cadeia, ele também "cuida":

MAA: aqui nós somo assim, sabe! É um grupo, nós somos unida, quando um fica doente, a gente faz visita, a gente somos muito unida aqui, Graças a Deus! Eu não tenho o que reclamar de ninguém.

Cria-se uma rede de apoio com o grupo. Grupos dessa natureza formados por pessoas da mesma comunidade de bairro, geram uma maior proximidade entre elas; as trocas tornam-se mais freqüentes, e encontros acontecem em outros espaços e momentos, o que faz com que o grupo fique mais coeso e solidário. 
De acordo com MONTEIRO (2001):

"Através da interação social realizada pelos individuos muitas transformações ocorrem e o significado de cada ação efetivada possibilitará a cada um construir novos laços de relação, novas formas de compartilhar o aprendizado com outros individuos" (p.35).

\subsection{8 $O$ envelhecer de si e o envelhecer do outro}

Somos todos seres-no-mundo enquanto infinitas possibilidades. Estar comigo, cuidando de mim, estar com o outro cuidando do outro.

“O ser-ai é compreendido ontologicamente como cuidado. A perfeição do homem, o tornar-se aquilo que em seu ser é livre para as suas próprias possibilidades é o resultado do cuidado" (HEIDEGGER 2002, p. 169).

Este outro que envelhece, que se deixa envelhecer; a percepção de como e por quê o outro envelhece, são expressas em muitos momentos nos encontros. $O$ seguinte diálogo, ocorrido em um dos encontros traz bem ilustrada essas questões:

GS: Eu tenho uma irmà que tá com 70 anos, ela não sai, cê sabe que ela deu derrame, deu derrame, mas ela trabalha, como é que ela nảo pode sair? Ela tá esperando a morte. E a morte tá esperando ela. (risos)

TS: Também ela não gosta de conversar! Ninguém tá conversando com ela. Por isso que tá envelhecendo!

EE: Agora a $G$ tá se acabando, tá envelhecendo... a AMG (que não estava presente) eu acho que ela envelheceu! Olhando prá ela, eu acho!

LTB: (concordando com EE) Ela tá envelhecendo! Ah! Primeiro a AMG andava sempre arrumadinha, ela saia, ela pintava o cabelo. Ela ia dançar. Ela era prá frente, bonita ai ela parou com audo.

EE: Ela foi sair da ginástica, ela parou de ir no baile, ela foi se acabando...

NM: Acontece que se a pessoa não tem amizade com ninguém, não conversa, fica chocando, não tem divertimento, daí a velhice toma conta

LTB: Essa pessoa que fica parada lá, pensando na vida lá, só pensando na vida lá! Ai! não tenho dinheiro, ai! tô com dor no ombro, ai... 
A falta de contato, as limitações físicas e as preocupações são identificadas como fatores que envelhecem. $\dot{E}$ no outro que elas ganham mais destaque, pois são evidentes. Nestes depoimentos a falta de atividades grupais, expressivas, de autocuidado e as preocupações com os pesares da vida, atingem uma importância condicional na delimitação do processo do envelhecer. A velhice aparece como uma condição resultante de um estado de declinio, de degeneração.

No entanto, quando o processo é inverso, a identificação da melhora visível no outro aparece também expressas nas falas:

LTB: Aquela outra M. quando entrou na ginástica, parecia sim, dava até dó, quando ela entrou na ginástica, ela amarrava assim o cabelo, eu falava: nossa como ela é esquisita! De repente ela soltou a franga! Ela começou a se arrumar, ela se arruma ela pöe bermuda,? até os filho dela viram!

MCS: Eu encontrei a MLF num dia ela tava tão chique tão bem arrumada, de uns tempos pra cá ela melhorou, né? É outra pessoa.

A velhice identificada no outro também pode aparecer como um estímulo à sua própria, sendo de uma maneira positiva e estimulante, sendo de uma maneira negativa, de comoção. Este estar-com-o-outro é expresso nas falas, mas carrega sempre uma ambigüidade entre o ser e o sentir:

EB: Eu não aceito envelhecer. Mas aí a gente vê os artistas ficando véio na televisão vai se conformando. Você vê um Tarcísio da vida véinho, nossa! Quando você começa a sentir que tá envelhecendo é horrivel, comigo é assim! Não sei se todo mundo é assim! Eu acho horrivel!

TS: é a gente não ficá reparando assim, quando... é o que eu contei um dia, aquele véio gordo, andando, coitado, machucadinho, me deu uma vontade de chorar, cheguei em casa mais triste, aquilo lá foi uma pena prá mim, me doeu, ai meu Deus onde a gente vai parar. Justamente eu olhei aquilo passou (grifo meu)para mim. Foi aonde me deu vontade de chorar, ói ele tá assim e como eu vou ficar?

GS: Eu aceitar a velhice? acho que quando a pessoa não aceita ela fica ranzinza, fica impertinente eu já tenho visto isso! "Ai! essa música alta!!”

Eu já morei perto de gente que tava assim com uns 60 anos, ai! abaixa esse volume no rádio, gritava perto de mim. Eu não me importo com o rádio alto, com conversinha... Sábado nós fomos lá no Bonfum. Fui ver minha neta, ela foi dançar, dança de rua, minha nora já não tava agüentando mais, aquele alto falante, aquele povo falando e olha que ela é nova né! 43 anos, parece que ela tem. "Então a senhora não importa?" Falei não! Eu ainda brinquei com ela, "cê tá ficando velha"! (risos). 
Parece importante o enxergar no outro os sinais de velhice, sejam eles concretos ou simbólicos. É como se através da velhice vista no outro fique mais provável avaliar a própria condição. Seja pela negação dessa velhice assimilada por crenças ou por uma concepção individual, que associa a velhice a um limiar de baixa tolerância social.

De acordo com MONTEIRO (2001):

"o velho apresenta sua identidade definida pela relação que estabelece como outro, alteridade jovem. Nesse sentido, fica claro porque as pessoas não querem e não aceitam ser classificadas como velhas dizendo, muitas vezes, que possuem uma alma jovem em um corpo de velho"(p.47).

\subsubsection{O envelhecer e a importância da família e da sociedade}

AYÉNDEZ (1994) define família como sendo uma unidade social composta de várias pessoas relacionadas por laços de parentesco, sejam consanguíneos, pelo casamento ou por adoção, que conjuntamente satisfazem necessidades fisicas e emocionais, podendo viver juntas ou não. Investigações em todo o mundo indicam que a familia é a principal e a preferida fonte de apoio para os idosos e também a que $o$ acode em primeira instância.

As relações familiares refletem questões culturais e sociais (PAVARINI 1998).

A relação afetiva no âmbito familiar é um dos principais fatores de equilíbrio e bem-estar dos que envelhecem, os laços sentimentais construídos ao longo do tempo dados no seio da família, vão repercutir no apoio ao idosos e podem exigir um novo mapeamento das relações familiares (ASSIS 1998).

A familia, enquanto um suporte afetivo, aparece nas falas em forma de reconhecimento pelos ganhos obtidos com as novas atitudes, enquanto uma extensão de si próprio, uma continuação:

MRV: Sou muito apegada com minha família. Depois que eu vim para este grupo eu melhorei bastante. Minha sobrinha já percebeu que eu estou até parecendo mais jovem. 
EE: Eu tenho dez netos e me sinto muito orgulhosa. Nào aceitei e nāo aceito envelhecer. Tenho bisnetos, mas não quero que me chamem de Bisa, avó eu até que tive que aceitar.

$\mathrm{Na}$ velhice, os contemporâneos como os irmãos e primos, aparecem, muitas vezes, como únicos pares consanguíneos. Esses laços familiares, geralmente, sofrem um distanciamento devido às mudanças decorrentes da vida adulta: o casamento, os filhos, o trabalho, entre outros, dificultam aquela convivência anterior. Muitas vezes, na velhice, volta a aparecer a necessidade do reencontro, da re-união, se estes relacionamentos foram significativos para ambos. Os pais já morreram, os filhos são de outra geração, não viveram as mesmas histórias que os irmãos e primos. No entanto a distância que se formou pode ser um grande obstáculo, a falta de autonomia também. Em algumas falas expressadas aparece o pesar deste distanciamento e da falta de autonomia em relação a possibilitar esse reencontro:

EE: Acho que velhice é o que aconteceu comigo hoje, eu fiquei chocada fiquei triste: a minha irmã me ligou, “Ah EE vem prá cá. Nós tamos ficando velha! Faz tempo que nóis não se vê..." "Bom, eu não me sinto velha!" (Ela tem 72 eu tenho 74) ela disse "nem eu me sinto velha, você vem prá cá, você tem seu dinheiro, você pode vim, você entra no ônibus a gente te pega". "Maria não posso. Meus filhos não me deixam nem ir na ginástica sozinha, tenho que ir acompanhada agora vou prá São Paulo sozinha!? Não vou Maria”. Eu fiquei tão triste, isso envelhece a pessoa...

Aparece nesta na próxima fala a comparação entre a sua velhice e a velhice do irmão, como uma medida do quanto e do como, aquele que é do mesmo tempo e da mesma matriz biológica, pode envelhecer:

GS: (falando da irmã) Então eu acho que ela não tá aceitando a velhice e eu aceito da maneira que for eu aceito, passeio, agora cada vez tem programa melhor prá nós, que nem esse programa que cê tá fazendo (teatro) prá nós tá uma beleza, né! Tá sendo muito bom, eu gosto demais. Vamos ver se o ano que vem nós tamos juntas outra vez (risos).

A velhice aqui assume uma conotação diferenciada, como um projeto de vida, de "terceira idade", com todos os seus programas de inserção social e de qualidade de vida.

Os filhos aparecem como tutores quando a pessoa idosa apresenta uma condição de doença. Mesmo que esta não sinta este fator (a doença como limitante). 
A conduta da familia tem uma importância expressada nas falas, sejam de ajuste ou desajuste:

MLF: Ah! Não! a gente fica assim jogada prá lá! Por que é veia! não! Na minha casa eu me sinto! Mas quando eu tô aqui com meus amigos, não. Já na minha casa, eles nem dão bola prá mim.Às vezes eu penso, assim ah! a gente dá bola prás coisas que passa nervoso lá em casa, daí elu não vou ligar próssas coisas, porquê quem vại se acabar sou eu, então eu jogo prá trás.

OMS: Eu acho que na velhice os filhos tem que ter cuidado com os pais, deixar os pais passear, e näo falar que é velho, tem que aproveitar a vida, não ligar pro que os filhos falam, sair, e passear, não dar bola para que os filhos falam.

MCS: Minha netinha de 7 anos chega perto de mim e diz: "Vó cê vai no baile hoje"? Vou. "Vó cê tá tão linda, vai linda mesmo, prá você arranjar um namorado, prá você beijar na boca. A senhora tem que aproveitar tua vida.

JP: Não pode fazer isso! Todo mundo é prá enterrar! Eu não quero não ficar amolando. Eu tava conversando com meu filho, ele falava que velho é assim mesmo é só mijaceira, ele tem razão é tanta mijaceira...(risos)

O seio da família é o primeiro lugar onde se aprende a amar, seja de que maneira for. O homem provém de um grupo, mas ao perfazer seu caminho ao vivenciar-se como pre-sença no mundo, ele o faz individualmente.

"O homem cria o próprio mundo e, ao fazer isto, realiza suas próprias potencialidades" RIBEIRO (1985 p. 39).

Para o mesmo autor, em suas considerações sobre o existencialismo apoiadas em Sartre, o homem se escolhe sem experiências prévias e ao mesmo tempo é por elas limitado. Ele (o homem) é o único ser no universo que tem a capacidade de conhecer e cuidar de sim mesmo, através de sua subjetividade, deste olhar de dentro para fora, impedindo de se tornar objeto, coisa como as coisas.

$\mathrm{Na}$ esfera social o homem satisfaz sua vivência-com-o-outro. Ele participa das experiências plurais e coletivas. Mas ele é o Dasein, uma presença individual diferenciada no mundo.

As falas das participantes expressam ainda para a maneira como a sociedade as vêem, como os outros, desconhecidos, que fazem parte do seu mundo de interações, do seu cotidiano, interagem e as tocam: 
GS: Não ligo que me chamem de véia. Outro dia no ônibus, um rapaz virou para o outro e disse: “Não vou dá lugar para esta véia não!!”. Eu dei risada e achei graça. Sou véia mesmo fazer o quê!!

TS: Mas é uma beleza! (se sentir paquerada) Sexta-feira, (levantando-se) no baile, um senhor de Jardinópolis falava assim para mim "mas você tem um corpinho, hein? Quantos anos você tem, que mal lhe pergunte? Eu falei 59! Eu tava dançando, e o homem "você é elegante, tem um corpo bonito" você é bem conservada, eu falava "é". Lá tem uns velhos prá frente!

GS: Um dia eu tava indo no show de chorinho, a TS tava lá, a professora ia ensinar a gente a dançar, eu ia indo embora e nem vi um homem que tava lá, me olhando e mexeu comigo: "a senhora tá me devendo uma dança"! Eu nảo tava com vontade de dançar, se eu quisesse eu saia pisando no pé dele, aí eu falei: "eu vou pagar um professor para me ensinar a dançar e nos vamos dançar a noite toda, só com você , ele ficou olhando e disse: "tá bom, eu vou cobrar!"

Nesse universo de busca, de retomada de experiências e autonomia, é possível também observar que valores e códigos de intervenção entre os sexos também está presente na realidade das participantes.

\subsubsection{Ambigüidades e contradições em relaçāo a ser e sentir-se} envelhecendo

"o nosso existir é realmente muito incerto, pois se desenvolve mim processo cheio de ambigiuidades e de riscos cuja imprevisibilidade nos impede de ter segurança ao agir...o presente é também abertura para o futuro e este é sempre imprevisivel...peculiaridades...que vão além daquilo que conheço agora..." FORGHIERI (1984 p. 19).

Nos depoimentos foi possível encontrar várias facetas da mesma situação, as ambigüidades, é claro, estão presentes durante todo o tempo no trabalho:

- Manifestando a aceitação da velhice enquanto uma ambigüidade no ser e no sentir:

G.S: Eu aceito, mas eu nào me acho velha!

GXS: Eu tô velha, não, eu nāo me acho velha! Só tô de cabelo branco! 
- Expressando a angústia contida no sentir-se envelhecendo, e ao mesmo tempo que não reconhece o envelhecer:

NM: Envelhecer é ficar muito pensativa com as coisas, A velhice é natureza. Todos envelhecem.

NM: Que a gente sente envelhecer, sente.

NM: Não tem nada a ver a idade, porque eu tenho 74 anos! Eu tenho ânimo prá fazer tudo, se eu fosse velha eu não fazia tudo o que eu faço!

- Na vivência cotidiana apontando possibilidades, distantes do envelhecer e o envelhecer se mostrando enquanto dificuldades inerentes ao que considera-se envelhecer:

EE: Eu não tô velha, de jeito maneira! Sô tão esperta prá trabalhar. Eu faço minhas coisa, eu faço salgado, eu faço doce, eu faço tanta coisa, eu me viro

EE: Ahh Credo!! Não consigo mais subir em um banco. Ihh! Estou ficando véia. Eu que subia em goiabeira, laranjeira, hoje não consigo subir em um banco. Fico muito triste de não conseguir.

EE: Envelhecer é muito triste. Não quero envelhecer. Quero ir como eu estou indo.

$\mathrm{EE}$ : Tem nada, ela é nora, ela tem 60 e poucos anos. Véia sou eu e você!

Para JASPERS (1985, p. 911), o homem, por ser uma possibilidade aberta, capaz de transformações infinitas, deixa de ser o homem inteiro quando se determina. Em tudo que se determina ele coloca-se em situação tal, "que é como se fizesse certa tentativa de que pudesse retroceder, pelo fato de subsistir a possibilidade na base de sua essência".

Nas falas seguintes, aparecem ao mesmo tempo o envelhecer e a morte, ambos mostrando-se bastante indesejáveis, os indícios do envelhecer se contrapõem à vontade de não-envelhecer que esta participante expressa:

EB: Envelhecer é muito ruim. Queria ficar sempre nova. Não queria envelhecer. As pernas vão ficando fraca.

EB: Eu também não alembro nem da morte, nem da velhice.

EB: Não me sinto velha, só sei que tô ficando velha.

EB: Eu não penso em ficar velha, porque eu não vou ficar velha! (risos) Tem dia que eu não penso, que eu quero durar muito e pronto. A única coisa que me apavora é a morte! Tenho horror de morrer. Nāo quero morrer de jeito nenhum, só isso! 
O movimento de vaivém observado mostra a construção de um significado de velhice socialmente construído que se contrapõe à maneira de sentir e conceber a vida e a própria "velhice".

Segundo JASPERS (1985, p. 917), o homem realiza-se em "determinados fenômenos, atos, pensamentos, simbolos"; e volta-se sempre, por sua vez, contra cada um desses fenômenos que se tornaram determinados, "contra suas próprias determinações".

\subsection{O significado do envelhecer para as idosas}

Ao buscar o significado do envelhecer para essas idosas, através dos discursos gerados pela questão norteadora, cheguei à seguinte proposição:

A velhice é uma condição humana associada à perdas, doenças, sofrimentos e limitações, derivada enquanto tal, de raízes pré-concebidas e apreendidas, contrapondo-se ao sentido da vida, que está associado aos ideários de juventude. Os determinantes da velhice, concebida como tal, são os eventos negativos como doenças, angústias e preocupações. Entregar-se à velhice, portanto, significa não viver a vida, entregar-se à morte, ou melhor, morrer em vida.

A velhice é um estado de ser, que pode ser assumido pelo pensamento e pelas atitudes de identificação com seus aspectos negativos. Ao não assumir a velhice, se assume a vida, abrindo-se para suas possibilidades infinitas.

O envelhecer é acompanhado de alterações físicas, orgânicas e mentais. Elas são sentidas como negativas e limitantes, quando dificultam a atuação das pessoas no mundo da práxis e das relações. A dependência surge quando as alterações são vivenciadas na forma de doenças que levam a perdas definitivas, limitações e que portanto, expropriam o ser de si. A perda da autonomia e a dependência são fatores temidos na velhice e podem fazer a pessoa retirar-se do mundo das relações, resultando em sua "morte social". As transformações corporais que não diminuem a qualidade de vida e que não prejudicam os relacionamentos sociais são as mais toleráveis. 
A velhice é aceita como uma fase natural do ciclo de vida, e como tal, contém um momento de reflexão autobiográfica, no tocante ao desempenho de papéis e às tarefas cumpridas. Por meio deste reconhecimento de si enquanto ser-no-mundo que vivencia seu projeto de vida, experiencia a sua própria finitude e as suas infinitas possibilidades.

A classificação etária é uma medida demarcatória, socialmente apreendida, que não condiz com as realidades experienciadas enquanto um tempo de vida próprio. $\mathrm{O}$ acúmulo de anos não é vivenciado como condição limitante, mas delimitante.

É no outro que se percebem os sinais da velhice enquanto um fato e através dele é possível conceber a sua própria, seja no aspecto positivo ou negativo. O outro é espelho. A sociedade assume uma importância significativa no processo da vida, pois através dela o ser se realiza. $O$ mundo ao redor, do qual a sociedade e a familia fazem parte, é dotado de significados identificados como próprios. É através dele que o ser se realiza enquanto ser-no-mundo.

A velhice é também vivida como um período de liberação dos deveres sociais e familiares, havendo disponibilidade maior de tempo para cuidar de si. Ao redescobrir a própria vida, abre-se para o mundo, propiciando uma renovação de valores, um resgate do tempo perdido, levando a elaboração de um novo projeto pessoal de vida. Assim, ao cuidar de si, de sua saúde, de sua aparência, fazendo planos futuros, liberta-se da morte em vida.

As atividades grupais são os principais meios que promovem uma identificação desse ser-no-mundo. Pela reciprocidade que é vivenciada, o grupo desempenha um espaço acolhedor onde o ser se realiza, onde pode formular a suas necessidades e anseios, atuando conjuntamente.

Ao mesmo tempo em que observa a velhice no outro e a assume também para si enquanto ser-no-mundo, descobre que sua pre-sença não envelhece.

Neste capítulo objetivei tornar manifesto o que emergiu dos depoimento das participantes a respeito do significado do seu próprio envelhecer. No entanto, essa discussão poderia ser bastante aprofundada, levantados outros tantos aspectos, dada a 
riqueza de colocações reveladas. Espera-se que futuras investigações a esse respeito explorem muitas outras de suas possibilidades.

O processo foi bastante intenso, as vivências do teatro espontâneo do cotidiano facilitaram a expressividade das participantes; a situação grupal proporcionou um acolhimento.

Portanto o teatro mostrou-se enquanto uma estratégia que permitiu, entre outras coisas, o acesso a essa inquietação, pela sua qualidade de ser ao mesmo tempo um facilitador ao estimular a expressão e um agente transformador.

No próximo item, faço uma breve discussão de como essa atividade esteve presente nesse processo de desvelamento do significado do envelhecer para as participantes, trazendo algumas de suas qualidades terapêuticas à luz, situando-o enquanto coadjuvante desse processo, porém não me proponho a discorrer profundamente sobre este assunto, uma vez que este não foi o objetivo deste estudo.

\subsection{Vivenciando o teatro espontâneo do cotidiano}

Em todo o percurso desta pesquisa, o teatro espontâneo do cotidiano mostrou-se uma atividade facilitadora aos momentos dos discursos/diálogos. Quando a questão norteadora foi colocada após as vivências teatrais, essas vivências estimularam a reflexão sobre o envelhecimento a partir do que foi vivenciado nas dramatizações, atuando como um catalizador.

A partir dele foi possivel reavivar o fenômeno do envelhecer (e da vida no envelhecer), tornando-o passivel de experiência.

Quando esta questão foi colocada antes da dramatização, o teatro foi o veículo de expressão desse significado. Além de ser um canal de expressão genuína, mostrou-se um importante recurso terapêutico.

A seguir, destacarei dos encontros algumas relações entre o que suscitou o teatro e o que foi suscitado por ele, em relação ao objetivo proposto neste estudo.

No terceiro encontro é possivel localizar esse papel de deflagrador que possui o teatro. A questão norteadora foi primeiramente colocada, os depoimentos mostraram-se no conjunto, voltados para aspectos socialmente apreendidos. $\mathrm{O}$ tema a 
ser vivenciado envolveu a concepção social de velhice, enfocado nos preconceitos sociais sofridos pela pessoa que aparenta ser "velha". Foi encenado "um dia no ônibus", composto por histórias evocadas pelo tema - preconceito social sofrido pelo idoso- gerado a partir das vivências cotidianas de cada participante. Foi "criado" um fio condutor para a improvisação e a vivência aconteceu de uma maneira bastante intensa. Todos participaram ativamente. Algumas frases podem ser destacadas:

O motorista (representado neste momento, pela colaboradora AC) também provocava as senhoras e elas respondiam: Ô seu motorista, você está carregando gente e não animal. Dá para o senhor ir devagar." "Um dia o senhor ainda vai ter a idade que nós temos e quero ver o senhor chegar lá. Aposto que não vai ter esta disposição que temos nós dançamos fazemos ginástica, nos divertimos, entre outras coisas que eu duvido que você vai agüentar.

Após esta vivência, foi colocada novamente a questão norteadora, e, desta vez, as falas trouxeram um conteúdo mais subjetivo, fazendo emergir as vivências que cada uma tem do seu processo do envelhecer. Como ilustração, destaco os seguintes depoimentos:

EB: Envelhecer é muito ruim. Queria ficar sempre nova. Não queira envelhecer. As pernas vão ficando fraca. Eu adorei o trabalho, gostei de tudo, foi ótimo. Ótimo mesmo...

EE: Adorei, julgava ser tào diferente. Achei muito bonito. Todas as amigas foram muito legais. Envelhecer é muito triste. Não quero envelhecer. Quero ir como eu estou indo.

MLF: Gostei das brincadeiras, da ginástica, do cobrador de ônibus. Envelhecer é se entregar, se abandonar, é não se aprontar, não se divertir. Eu nảo fazia isto. Eu ficava muito triste, estava entrando em depressão. Hoje já estou bem melhor. Fui até para Santos passear com minhas amigas aqui do grupo da terceira idade. Gostei muito das brincadeiras. Lembro das brincadeiras e fico cantando. Pensei que fosse muito difícil. Pensei comigo: Será que eu vou passar vergonha!!!

$\mathrm{Na}$ interação grupal que foi promovida, as questões de uma participante suscitavam as questões da outra e uma dinâmica grupal de deflagração de sentimentos e emoções foi acontecendo.

O quarto encontro trouxe um grupo bastante motivado, uma das participantes trouxe uma carta onde relata sua concepção de envelhecimento: 
“Um dia nós vamos ficar velhos

E nós precisamos aproveitar bastante a vida até quando velhos

Ir à ginástica, baile, passear com os amigos,

A família faz parte da nossa vida,

Com o apoio dos filhos, assim, podemos suportar a tristeza, a alegria, a dor, e o medo.

Zelar pela saúde e envelhecer

Sofrimento inimigo da velhice são as doenças cardiovascular.

O envelhecer não é doença, velhice é uma coisa que ninguém quer ter,

Com o passar do tempo todos nós temos,

Precisamos de carinho, paciência, compreensão a todos,

As pessoas idosas é possível envelhecer feliz com saúde

Pessoas viviam até 60 anos, agora até $75,80,85$ anos sem tantos sofrimentos.

Inimigos da velhice são doenças cardiovasculares

Apoio familiar ajuda a superar a dor, tristeza e o medo. Zelar pela saúde e envelhecer feliz

Velhice tem que aproveitar, dançar, passar, viajar, divertir bastante até quando puder”

Nesta carta, os aspectos do envelhecer enquanto uma fase natural do ciclo da vida comparece, juntamente com aspectos negativos como doenças e sofrimentos, bem como, com aspectos positivos como as atividades de lazer e as atividades grupais. A velhice é um tempo que deve ser aproveitado como todos os outros, onde a manutenção da saúde, a manutenção das atividades de lazer, de autocuidado e convivência social, complementadas pelo apoio familiar, são condições para um envelhecer feliz.

A leitura em voz alta desta carta, despertou outros depoimentos que seguiram na mesma direção. Foram destacadas, nos depoimentos, as atividades que promovem um envelhecimento feliz, como as atividades grupais de ginástica, o teatro, os passeios e o autocuidado. Os aspectos positivos da velhice enquanto um tempo de renovação, de possibilidades novas esteve presente em todos os depoimentos. As vivências negativas do passado surgiram de maneira a valorizar o presente, o tempo de muitas possibilidades e libertação. "A velhice estava no passado", denotando uma concepção de velhice similar ao que é decadente, rejeitado. A velhice portanto, aparece como sendo apenas um rótulo, que pode ser retirado. É uma condição imposta a quem não vive a vida de maneira socialmente ativa, a quem aceita seus desígnios de solidão, de doenças, de condição última da vida, preâmbulo da morte. Conforme ilustra o seguinte depoimento: 
TSS: Eu já fui velha, mandei ela tudo prá trás, já faz 9 anos eu tô me sentindo jovem.

No quinto encontro o tema levantado a ser dramatizado foi um dia numa Unidade Básica de Saúde, pois a conversa inicial levantou questões relativas ao mal atendimento que era dispensado a muitas das participantes neste local. A questão norteadora não foi colocada antes da encenação pois o diálogo inicial foi bastante intenso e confluiu espontaneamente para a dramatização.

A encenação apresentou muitas facetas de como acontecem as vivências cotidianas nesse espaço de atenção em saúde, trazendo muitos dos significados que essas vivências suscitam em cada um.

Algumas das cenas que delatam esse "mal atendimento" são destacadas a seguir:

Pacientes: "Porque eles não atendem ninguém. Nóis tá aqui desde manhã..." "nóis tá com fome, com sede e não pode sair daqui" "tem gente que fica comendo ai" "as crianças chorando também! Não tem como esse posto ser assim desse jeito"

Pacientes: "nào tem bebedouro de água gelada, tern que pegar água da torneira. Essa água de torneira sabe lá..., uma porcaria..." "nāo tem papel higiênico" "não tem nada! Tá uma sujeira!" "nào tem remédio"

Em continuidade a essa vivência foi proposta a encenação de como seria um bom atendimento. Antes de iniciar a dramatização houve um diálogo sobre as vivências cotidianas reais de cada participante, a primeira encenação, embora fictícia e "exagerada", levantou lembranças de situações reais, que as participantes manifestaram a necessidade de colocar:

NM: - Eu tava com uma dor aqui na barriga, fui ao médico, ele passou a receita direto sem me examinar. Ele receitou, e eu não tomei, às veis que acontece isso eu não tomo.

EE: Eu sei que uma vez eu levei meu marido já falecido que tava doente, ele tava muito nuim mesmo. O médico demorava, demorava. Sei que meu filho foi lá e falou os diabo "meu pai tá ruim, pelo amor de Deus esse médico não atende por quê?" aí a enfermeira perguntou quem era o médico dele, e o meu filho respondeu "Ah é o doutor fulano, tá aqui a ficha." A enfermeira pediu para que esperasse mais um pouco... nossa ele começou a xingar e dizer que o pai tava nuim. Aí ele foi chamado.

A encenação do "posto de saúde ideal" trouxe algumas questões levantadas por elas que envolvem elementos de mudanças nesse espaço de assistência, 
apontando para um atendimento mais humano por parte dos funcionários, para a não falta de remédios e de médicos, além de melhor qualidade desse atendimento médico.

No momento seguinte, foi colocada a questão norteadora. Os depoimentos em relação ao significado do envelhecer elucidam experiências e concepções relacionadas à saúde, à doença, à morte, à idade. Trazendo como predicado que a melhor maneira de viver a vida é não viver a velhice, negando-a, na forma como ela se apresenta pelo esquema de valores e crenças sociais, tornando essa fase da vida similar a uma vivência própria do ideário de juventude: atividades, passeios, descontração, despreocupação, vivências amorosas, além de todas as atividades rotineiras que fazem parte dessa fase da vida:

EE: Não sô velha não, ainda . Olha se a gente continuar com esses médicos aqui do Postinho a gente vai ficar véia mesmo! A gente vai mudar viu, a gente fica nervosa óia!

LTB: Ter sempre aquela idéia de jovem, viver a vida, tem que passear, viver, brincar, tudo o que não viveu prá trás vai vivendo prá frente. Eu participo em tudo eu venho na ginástica, eu vou na Igreja, eu onde me chamam eu vou.

MCS: Porque no tempo que eu era moça eu nāo fazia nada e agora eu tô fazendo tudo. Eu tô passeando, eu tô andando hoje, eu tenho muita amizade, eu danço, eu paquero os homens no baile eu tenho tanta amizade. Tem um paquera que liga lá em casa. De uns tempos prá cá eu não páro em casa.

O sexto encontro iniciou-se com uma conversa informal com as participantes do grupo onde vários assuntos foram abordados, como o autocuidado relacionado com a auto-estima, com a vaidade, com o corpo. O tema para a dramatização foi decorrente de um dos exercícios de aquecimento, que consistia em cada participante imaginar um desejo que gostaria que tivesse acontecido no passado. A partir dos comentários iniciaram-se as encenações que trouxeram à tona algumas questões relativas à frustrações presentes de não realização de sonhos da juventude, principalmente no que concerne à atividade profissional. As dificuldades vivenciadas na fase da juventude, não propiciaram um encaminhamento profissional de acordo com seus anseios, a juventude apareceu como um tempo de poucas oportunidades para a maioria das participantes. 
Em um próximo encontro o tema para a dramatização surgiu da dinâmica dos exercícios preparatórios, que culminou em apresentações de músicas que foram cantadas por todas, suscitando lembranças passadas, dentre essas lembranças uma delas foi destacada para ser encenada.

A questão emergente nessa encenação foi a relação afetiva com o marido. A participante que foi a protagonista da re-vivência, ficou bastante emocionada. Expressando-se no final do encontro com o seguinte depoimento:

MCS: (Levanta com as mãos no peito) -deixa eu me abrir, deixa eu falar: Eu nunca pude falar, me abrir, nunca tive uma pessoa que eu pudesse falar, essa parte que você me mandou falar, eu tinha vergonha de falar as coisas, nunca me senti segura prá falar as coisas, agora não, eu me senti libertada prá falar o que falei hoje prá vocês, você meu travesseiro, aquele travesseiro que eu chorava, né, eu sei que eu deitei no teu ombro, assim prá mim foi tão bom isso aí, assim me desabafar, foi tão bom isso aí, eu me desabafei né, foi tão bom isso aí, fazia tanto tempo que tava guardando isso, né, pra mim foi uma beleza de presente, para mim vocês tão de parabéns.

De acordo com BOAL (1996) ao definir o fenômeno que ocorre em uma cena de terapia teatral:

“o protagonista que, na cena vivida, era sujeito-em-situação passa agora a ser o sujeito que observa a situação, na qual existe um Sujeito: ele mesmo. Ele ontem. Eu-hoje posso ver o eu-ontem, mas a recíproca não é verdadeira. Assim, agora sou mais (grifo meu)"(p.40).

Essa vivência levantou o aspecto dos relacionamentos afetivos e todas as participantes colocaram espontaneamente suas experiências relacionadas a esse tema, que neste encontro ocupou a maior parte do tempo. A questão norteadora, quando foi colocada após a dramatização, trouxe as questões dos relacionamentos vivenciados no presente como algo a ser re-conquistado. A questão da perda da beleza física como atributo de conquista foi levantada, trazendo como possibilidades presentes, aquelas relacionadas aos "encontros" sociais e atividades de lazer que ocorrem nos locais de encontros de idosos (bailes, festas, passeios).

É possível perceber que além de motivar uma reflexão mais aprofundada a respeito do significado do envelhecer para as participantes, o caráter terapêutico do 
teatro espontâneo do cotidiano, torna-se um caminho para reviver as vivências íntimas, sendo assim possivel refletir sobre elas e apropriar-se delas.

Outro encontro a ser destacado trouxe novamente a questão dos desejos, desta vez, orientados para o futuro. Neste encontro, as participantes exprimiram seus sonhos, mesmo que "distantes" da possibilidade de realização, pois alguns desejos necessitariam de recursos aquém das suas possibilidades reais.

De acordo com BOAL (1996):

“nossa vida é permanentemente marcada pelo desejo, pelo querer, pela necessidade, mesmo quando nosso ínico desejo é desejar..." (p.77).

Muitos dos desejos envolveram a saúde plena e a independência financeira, assim como aspectos relacionados com a convivência familiar, trazendo à tona algumas necessidades atuais de resgate da independência e privacidade.

Algumas das cenas vivenciadas trouxeram novamente a questão do autocuidado e da auto-estima, os cuidados com a beleza fisica foram ressaltados. Os depoimentos relacionados à questão norteadora também apresentaram esta interface, ilustrados a seguir:

MCS: Eu me sinto bem assim. Tem gente que não, tem muitas amigas minha que pensa assim: "eu sô velha prá que fazer isso?" Ah! Eu respondo ishi! Eu faço mesmo! Eu sou velha, mas gosto de me arrumar, no tempo de moça eu não podia, meu marido não deixava. Eu não gosto de ficar velha. Por isso que eu alevantô, já arrumada, pintada, prá não parecer que eu sô muito velha. Eu não gosto de ficar velha, mas eu não me preparo para não ficar velha.

Nos outros encontros as questões relacionadas aos relacionamentos familiares e afetivos foram novamente elucidadas. As re-vivências giraram em torno dessa temática, ao passo que, os depoimentos em relação ao significado do envelhecer trouxeram os medos e a negação da velhice e da morte, na forma do não pensar, ressaltando a importância do viver a vida.

JP: Não me sinto velha, não! Me sinto ainda com um pouquinho de coragem, ainda, gosto de conversar, passear é comigo mesma, eu não sou muito de conversar, mas passear, eu vou em tudo que é passeio, isso eu acho que tô podendo ainda. 
Como finalização das atividades de coleta de dados, foi solicitado às participantes que estavam presentes, que colocassem como o teatro espontâneo do cotidiano influenciou suas vidas em relação ao cotidiano, aos relacionamentos e em relação à saúde, cujos depoimentos são apresentados a seguir:

MLF: Minha vida antes era terrivel. Não tinha nada de bom, não tinha alegria, tinha só tristeza. Mas hoje parece que estou dentro de mar de rosas, me divertindo, rindo com as colegas. É tudo de bom. Não tem o que eu não gostei aqui no grupo, eu gostei de tudo.

A relaçào com a minha filha melhorou muito, antes ela nem falava comigo, me deixava jogada pelos cantos. Agora, quando foi o dia das mães e o meu aniversário, ela veio me dar um abraço e um beijo, coisa que ela nunca tinha feito antes. Fiquei muito feliz com isso. Este grupo me ajudou a mudar também meu jeito de tratar ela.

Prá mim eu estou bem, antes eu estava mal da coluna, dos rins, da diabetes e pressão alta. Hoje estou bem demais não sinto mais nada.

MCS: Minha vida tá ótima, o grupo me ajudou muita coisa, até a gente se soltar um pouco. Esse negócio de teatro eu era muito insegura eu achava tudo difícil. Agora não. Eu tô mais liberada para fazer as coisas e me soltando cada vez mais. Tudo ficou mais fácil. Minha vida mudou muito para melhor. Hoje eu danço, vou em tudo sem vergonha nenhuma. Quando eu era jovem nunca tive esta oportunidade.

As minhas filhas me vê e ficam admiradas: "Mãe, vê como a senhora era e como a senhora está hoje, a senhora melhorou muito e nós ficamos felizes com isso"

De primeiro, eu precisava tomar calmante, hoje tomo só 2 comprimidos para controlar a pressão. E, graças a Deus! ela está bem controlada.

TSS: Sou o que sou do começo até agora. Quando a gente não vêm, não é porque a gente não quer, é porque temos outros compromissos. Este grupo aqui é bom demais. Me distrai muito a cabeça, a gente fica mais unida, mais amizades. No tempo de criança a gente não teve esta oportunidade, me sinto uma menina aqui, a gente fica alegre e chora ao mesmo tempo. Me sinto bem aqui, muito bem aqui.

TS: Eu sempre fui desse jeito aqui mesmo. Tem dia que a gente fica um pouco caidinha, mais logo levanto. Gosto de vir aqui e fazer as coisas prá gente dar risada. Com este trabalho ficamos mais satisfeita com as coisas, e neste sentido mudamos bastante somos mais alegres.

OMS: $\grave{E}$ uma atividade boa prá gente se distrair, eu considero que me desenvolvi bastante para falar e participar das coisas. O que eu gosto mais no teatro é representar os papéis, eu adoro isso.

MAA: Eu sinto muito bem aqui. Parece que a gente fica mais feliz, na minha casa prá vir aqui eu deixo tudo em ordem, tudo amumadinho e venho tranqüila prá cá.

O tanto de doença que eu tenho (doença de Chagas, Pressão alta, diabetes) e eu não sinto nada, estou ótima. O médico até já tirou o calmante que eu tomava e eu fico bem demais sem ele. 
O teatro portanto apresentou-se muito mais que um meio, foi agente de transformação. É possível notar por esses depoimentos, que alguns aspectos da vida, como a saúde, estão sujeitas, também, à maneira de conduzir a vida. A evidente melhora na saúde referida pelas participantes foram associadas às atividades deste "grupo expressivo".

Da mesma maneira, os relacionamentos apresentaram, segundo elas, uma melhora. A re-vivência das situações cotidianas onde esses estiveram bastante presentes, possibilitou alterações no modo de conceber esses relacionamentos, expressos como mudanças. As alterações dizem respeito a uma maior liberação e a uma alegria mais presente no cotidiano, que é percebida pelas pessoas mais próximas. Concluo no entanto, que não só as atividades teatrais, mas o grupo atuou enquanto agente transformador.

A partir das dramatizações foi possível encontrar que a vida com suas múltiplas facetas é muito mais significativa para as participantes do que o próprio processo do envelhecer. A reflexão sobre esse processo aparece quando solicitada e vem permeada de dúvidas: eu sou, mas não me sinto. Eu quero mais é viver. Eu deixo a velhice para trás, eu não quero ficar velha. Envelhecer é muito triste.

As negações da velhice, dessa velhice imposta, que não cabe ao que se espera da vida, nos remete a descartá-la. A velhice ficou velha, ela caducou. O tempo presente é hoje e nele é que se vive. A idade não significa nada, somente para os papéis que são preenchidos. Viver a própria vida é a grande aventura humana.

Em busca do sentido do envelhecer encontra-se revelado o sentido da vida com todas as particularidades e generalidades dessa fase da vida.

Como nos contempla, brilhantemente, Fernando Pessoa:

"Tem só duas datas - a de minha nascença e a da minha morte. Entre uma e outra cousa todos os dias são meus". 


\section{Capítulo 7}

\section{CONSIDERAÇÕES SOBRE O ESTUDO}

"Se eu pudesse viver de novo a minha vida, na próxima trataria de cometer mais erros. Relaxaria mais. Seria mais tolo ainda do que tenho sido. Na verdade, bem poucas coisas levaria a sério.

Contemplaria mais entardeceres, subiria mais montanhas, nadaria mais rios, começaria a andar

descalço no começo da primavera e continuaria assim até o fim do outono. Porque, se não o sabem, disto é feita a vida, só de momentos. Não percam o

agora."

(Autor desconhecido in Rubem Alves "As cores do crepúsculo: a estética do envelhecer". Campinas, SP. Papirus editora. 2002, p.156) 


\section{Capitulo 7}

\section{CONSIDERAÇÕES SOBRE O ESTUDO}

Quando me propus neste estudo compreender o significado do envelhecer para quem envelhece, busquei adentrar nesse mundo.

A orientação do referencial teórico-metodológico da fenomenologia foi inédita para mim. Enquanto pesquisadora tive que compreendê-lo, deparando-me com algumas limitações perante esse referencial. Em alguns momentos a dúvida se fez bastante presente, frente aos desafios gerados pela mudança do enfoque metodológico a que estava acostumada e que permeia a formação dos profissionais da área da saúde, como eu. No entanto, esse referencial vislumbrou outra concepção de homem que satisfez meus questionamentos naquele momento.

Conjuntamente ao trabalho de campo fui aprofundando as leituras no referencial da fenomenologia, e, ao mesmo tempo que as incertezas e limitações me paralisavam, o encontro com esse referencial me movimentava, me motivava.

A literatura existente sobre a gerontologia e a geriatria é extensa e têm crescido exponencialmente. Isso se dá devido, principalmente, ao novo cenário atual apresentado em relação a essa temática porém, estudos de abordagem fenomenológica dessa natureza são escassos nessa área.

Em terapia ocupacional, desconheço estudos com essa confluência teóricometodológica. Embora essa profissão ainda esteja dando seus primeiros passos em termos de produção cientifica nacional.

Ao empreender uma pesquisa que permitisse compreender o significado do envelhecer para as pessoas que envelhecem, poderia ter recorrido somente à utilização da entrevista como uma forma de ter acesso ao mundo-vida dessas pessoas, mas como terapeuta ocupacional que sou, reconheço o grande potencial mobilizador das atividades, principalmente das expressivas.

O teatro espontâneo foi um grande aliado, enquanto estratégia, para me aproximar do objetivo pretendido, devido a sua capacidade em facilitar a expressão humana. As idosas receberam a atividade do teatro espontâneo do cotidiano com um entusiasmo crescente a cada novo encontro, envolvendo-se com sua proposta. Ao passo que aconteciam os momentos de discussão onde a questão norteadora era 
colocada, gerando muitas reflexões, em parte pela facilitação provocada pela atividade teatral, em parte pela oportunidade em discutir essa questão em um grupo de pares. A gama de possibilidades que o teatro oferece, enriqueceram o conteúdo deste trabalho, despertando uma reflexão maior sobre o sentido da vida nas idosas do grupo estudado. Concordo com BOAL (1977) quando diz que:

"o fenômeno teatral, quando se processa livremente, produz uma extraordinária expansão de energia" (p. 110).

Fui percebendo que a cada desvelamento do fenômeno estudado outros velamentos aconteciam. Pareceu-me uma caminhada infinita. Mas o tempo para iniciar e terminar um trabalho desta natureza é finito e bem demarcado. Compreendo que estou apenas iniciando uma trajetória.

Neste movimento de compreensão procurei manter-me fiel diante dos acontecimentos. A partir dos discursos das participantes foi possível colocar em evidência e tematizar de forma simples o sentido do envelhecer para aquele que envelhece.

Foi possível apreender através dos discursos, o caráter multifacetado do envelhecer.

Se por um lado as participantes se mostraram aceitando o envelhecer como um processo natural, por outro, o relacionam às doenças e à decrepitude.

O envelhecer é identificado no corpo na forma de transformações. Essas transformações naturais nem sempre são bem-vindas. Observa-se uma tentativa de minimizá-las, principalmente enquanto determinantes da beleza, orientados por um padrão estético vigente.

A associação entre velhice e morte, gerada pelos valores e crenças sociais vigentes, em parte aterroriza e paralisa as idosas. Essa relação parece não ser vivenciada de uma forma tranqüila. A prática do "não pensar" sobre o assunto parece ser a forma mais imediata de tentar se proteger da dor e dos medos provenientes dessa realidade.

As atividades grupais assumem uma dimensão proporcionalmente oposta à vivência do ser-para-a-morte. Elas vivificam, motivam, fazem rejuvenescer. 
As relações dai formadas apresentam-se com vínculos fortes, como um apoio sempre presente. Há um entrelaçar de vidas. $\mathrm{O}$ cuidado-com-o-outro é evidenciado. No sentido heideggeriano, o termo solicitude cabe bem nessa postura, uma vez que sugere o relacionamento envolvente e significante com o outro da relação, pautado por paciência e consideração.

As vivências teatrais enriqueceram sobremaneira esse desvelamento. Permitiram um alcance além do que é retido pela memória e recordado intencionalmente. Ele possibilitou a re-vivência de situações cotidianas significativas, que trazem sempre presente o sentido do envelhecer.

Por meio do teatro as emoções puderam vir à tona, não somente através do discurso, mas dos gestos, da expressão corporal, de brincadeiras e diversas atividades a ele relacionadas.

O grupo constituiu-se em um catalisador, movimentando as experiências trazidas por cada um. Muito possivelmente a interação estabelecida entre as participantes, através dos grupos, proporcionou uma importante fonte de suporte social entre elas.

Os pressupostos da fenomenologia fizeram emergir uma postura compreensiva em relação ao envelhecer e fui aos poucos me despojando da visão da ciência tradicional onde a velhice é considerada a fase mais decadente do ciclo de vida, para onde o velho é considerado um ser existindo.

Ao assumir a dimensão existencial do homem e por conseguinte a minha própria, passei a compreender através da minha existência o que sinto a respeito do significado do envelhecer, que é o sentido da vida .

As pessoas sentem o corpo físico envelhecendo, pedindo mais descanso, pedindo cuidado. E percebendo essas alterações, utilizam os códigos que aprendeu socialmente para explicar essa transformação. Nem sempre esses códigos favorecem essa fase do ciclo de vida, surgem as doenças, o isolamento, a retirada social, além das perdas naturais. Acredito que essa inadequação humana não trouxe benefícios para a humanidade, pois esta também envelhece, numerosamente e por mais tempo.

Acredito que se buscarmos compreender o mundo com uma postura compreensiva, será possível trilhar novos caminhos para construir uma prática terapêutica voltada para o mundo-do-ser-que-envelhece e para o ser-do-mundo-que- 
envelhece, onde valores como disposição amorosa, solicitude, integridade, pureza, força, fé, harmonia e simplicidade permeie as relações dos uns-com-os-outros-nomundo, considerando sua historicidade e suas crenças.

O envelhecer enquanto fenômeno pode ser compreendido de diversas maneiras. Sob a ótica da saúde, estudos desta natureza podem trazer muitos beneficios, uma vez que nos serviços de saúde são os próprios idosos que buscam assistência e não um conceito do que seja idoso. A partir de dinâmicas dessa natureza abrindo possibilidades de discussão de trabalhos com profissionais de diversas formações, pela orientação fenomenológica é possível direcionar a assistência para a eksistência.

Em um dos encontros descritos nesse estudo, as participantes vivenciaram uma UBDS ideal (sugere-se para uma maior compreensão dessa questão a leitura da transcrição desta experiência no Anexo 1). É de uma riqueza e de uma simplicidade comovente. As respostas partem do próprio usuário. Mas como tornar possível sua concretização mais generalizada? Como viabilizar as alterações necessárias?

São perguntas que podem ter respostas, adequadas aos sujeitos que estiverem vivenciando este serviços.

Enquanto docente tenho a preocupação com a formação de futuros profissionais da área da saúde, que contemple uma visão mais humanista e integral de homem, considerando sua subjetividade enquanto um dos pontos importantes do processo de tratamento e cura, procurando compreender o mundo-vida desse homem antes de propor intervenções.

Espero que os aspectos salientados possam contribuir para a reflexão e planejamento de uma atenção voltada para o idoso. Por meio do presente estudo, foi verificado que é possível propor um trabalho de tal natureza, com profissionais devidamente formados ou dispostos a isso, atividades como esta são valiosos aliados na Promoção da Saúde e não onera o Sistema Público de Saúde. Outro caminho apontado é o da mudança na postura dos Serviços de Saúde, no sentido de um rearranjo social de idades e geracionais, estimulando a formação de grupos intergeracionais voltados para o autocuidado na sua concepção mais ampla e acrescentando aos programas de saúde, ações que promovam a saúde por meio da 
formação de grupos terapêuticos e/ou educativos não só agregados por patologias ou por faixas etárias.

Outros estudos poderiam ser realizados e direcionados a contextos diferentes dos que foram abordados neste estudo, como investigações a respeito de idosos de outros níveis sócio-econômicos, idosos em grupos mistos ou ainda, somente grupos masculinos, levantando outros viezes da questão relacionada ao envelhecimento. Sendo assim, muitas pesquisas precisam ainda serem desenvolvidas para investigar e criar alternativas que cumpram ao propósito a elas destinado: contribuir e incrementar o bem-estar do homem no mundo.

É necessário investir fortemente em recursos humanos, o que ainda é um desafio para a realidade brasileira.

Gostaria de ressaltar que a convivência com aquelas pessoas trouxeram-me uma satisfação enorme, pude mais uma vez trabalhar com o teatro espontâneo do cotidiano onde encontrei também minha própria expressão.

Acredito que este pode ser um dos muitos caminhos para se trabalhar questões tão presentes e tão veladas no cotidiano das pessoas que buscam tratar sua saúde.

Escutar e buscar compreender o significado do envelhecer, mostrou-se revelador, a partir do qual repenso meu próprio sentido de viver e envelhecer. 


\section{Capítulo 8}

\section{UMA REFLEXÃO CRITICA DESSA TRAJETÓRIA}

"Shiva disse:

Cada coisa é percebida através do conhecer. $O$ si-mesmo resplandece no espaço que atravessa o conhecer. Perceba o ser como o conhecedor e o conhecido". 


\section{Capitulo 8}

\section{UMA REFLEXÃO CRÍTICA DESSA TRAJETÓRIA}

Quando iniciei esse trabalho procurava buscar o significado do envelhecer para as pessoas que envelhecem. A partir do referencial fenomenológico que se descortinou diante de mim, acreditava que encontraria o desvelamento desse fenômeno. No entanto, ao compreender essa metodologia vivenciando-a na prática, descobri nas falas e nas vivências que o fenômeno que se desvelava diante de mim era o próprio existir, o fenômeno da vida. O que me parecia um fenômeno, tornou-se um fato. O estar velho é vivenciado em todas a suas dimensões pois somos-seres-nomundo-com-os-outros-seres.

No entanto, ao encontrar esse desvelamento, percebi que poderia ter escolhido uma maneira diferente de compreender o que eu julgava ser um fenômeno, pois tantas são as maneiras. Talvez, não perguntando coisa alguma, apenas experienciando com aquelas idosas somente o teatro (o que já é bastante), buscando apreender o seu sentido da vida ou do envelhecer. Mas, descobri que quando alguém se põe a pesquisar um fenômeno humano, esse alguém vem com suas concepções arraigadas, que foram as que $\mathrm{o}$ inquietou, e que, coincidentemente, as que $\mathrm{o}$ impulsionaram a essa direção.

Considero que o grande ganho pessoal e profissional nessa caminhada foi ter compreendido isso. E a partir dessa compreensão, buscar aprofundar novos estudos, empreender outros trabalhos, pois assim como uma tese, a vida é inacabada, repleta de infinitas possibilidades.

Todos envelhecemos. O fato de envelhecer enquanto estou vivendo também me lança para a morte, percebo minha finitude. Essa percepção me estimula a viver integralmente a vida, realizando meu projeto de vida, essa é a única opção se eu quiser continuar vivendo. Posso optar. Estou lançada nela. 
Capítulo 9

REFERÊNCIAS BIBLIOGRAFICAS 


\section{Capítulo 9}

\section{REFERÊNCIAS BIBLIOGRÁFICAS}

1. ADORNO RCF, CASTRO AL. O exercício da sensibilidade: pesquisa qualitativa e a saúde como qualidade. Saúde e Sociedade 1994, 3(2): 172-185.

2. AGUIAR M. Teatro espontâneo e psicodrama. São Paulo: Ágora, 1998.

3. ALVES R. As cores do crepúsculo: a estética do envelhecer. SP: Papinus, 2001.

4. ASSIS M. $\mathrm{O}$ envelhecimento e suas consequências sociais. In: $A$ saúde do idoso: a arte de cuidar/ org. Célia Pereira Caldas. RJ: EdUERJ, 1998.

5. AYÉNDEZ MS. El apoyo social informal. In: PEREZ EA et al. (eds.). La atención de los ancianos: un desafio para los años noventa. Washington, D.C.: OPS. Publicación Científica 1994, n 546: 360-368.

6. BARBOZA MMA. Ensinar Atividades: uma arte de Terapeutas Ocupacionais estudo sobre o ensino de atividades artisticas nos cursos de Terapia Ocupacional das Universidades Paulistas. São Paulo; 1996. [Dissertação de Mestrado Instituto de Psicologia da USP].

7. BARO F. Factores psicosociales y la salud de los ancianos. In: Washington, D.C.: OPS. Publicación Científica 1985, no 492: 87-92.

8. BERG $\mathrm{J}$ van den $O$ paciente psiquiátrico:esboro de psicopatologia fenomenológica. Trad de Miguel Maillet. SP: Mestre Jou, 1981.

9. BEAUVIOR S. A velhice. I. A realidade incômoda. $2^{\prime}$ ed. SP-RJ: Difel; 1976.

10. BENTLEY E. A experiência viva do teatro. Trad. de Álvaro Cabral. RJ: Zahar editores; 1967. 
11. BOAL A. Duzentos exercícios e jogos para o ator e o não ator com vontade de dizer algo através do teatro. RJ: Civilização Brasileira; 1977.

12. BOAL A. Teatro do oprimido e outras poéticas politicas. $6^{\circ}$ ed. RJ: Civilização Brasileira; 1991.

13. BOAL A. O arco-iris do desejo: método Boal de teatro e terapia. RJ: Civilização Brasileira; 1996.

14. BOTH A. Identidade existencial na velhice: mediações do estado e da universidade. Passo Fundo: UPF; 2000.

15. BRASIL. Política Nacional do Idoso - Perspectiva governamental. Brasília, 1996.

16. BRASIL. Estatuto do Idoso, Lei n. 10.741 de $1^{\circ}$ de Outubro de 2003.

17. CAPALBO C. Considerações sobre o método fenomenológico e a enfermagem. R. Enferm. UERJ 1994; 2 (2): 192-197.

18. CAPALBO C. Fenomenologia e ciências humanas, $3^{*}$ ed. Londrina: UFL, 1996.

19. CARVALHO FILHO ET, PAPALÉO NETTO M. Geriatria. Fundamentos, clinica e terapêutica. São Paulo: Atheneu, 1994.

20. CARVALHO FILHO ET, ALENCAR YMG de. Teoria do envelhecimento. In: CARVALHO FILHO ET, PAPALÉO NETTO M. . Geriatria. Fundamentos, clinica e terapêutica. São Paulo: Atheneu, 1994, p. 1-8.

21. CASELLI MP. et al. Valorização das Instituições Asilares enquanto agentes de transformação da qualidade de vida do idoso. Florianópolis/ SC; 1993. 
[Monografia de Conclusão do Curso de Especialização em Gerontologia Universidade Federal de Santa Catarina].

22. CASELLI MP. A morbidade hospitalar do idoso no municipio de São CarlosSP, em 1996. São Paulo; 1998. [Dissertação de Mestrado - Faculdade de Saúde Pública da USP].

23. CHACRA S. Natureza e sentido da improvisação teatral. São Paulo: EDUSP, 1995.

24. DARTIGUES A. O que é a fenomenologia? $8^{\circ}$ ed. Trad. de Maria José J.G. de Almeida. São Paulo: Centauro, 2002.

25. DEBERT GB. A reinvenção da velhice: socialização e processos de reprivatização do envelhecimento. São Paulo: Editora da Universidade de São Paulo. Fapesp. 1999.

26. FERNANDES JS. As pessoas idosas na legislação brasileira: direito $e$ gerontologia. São Paulo: LTR, 1997.

27. FERRARI MAC. Idade avançada: nova preocupação da saúde pública. São Paulo; 1981. [Tese de Doutorado - Faculdade de Saúde Pública da USP].

28. FORGHIERI YC. Fenomenologia e psicologia. São Paulo: Cortez Ed., 1984.

29. FRAGATA JS. Problemas da fenomenologia de Husserl. RJ.: Braga Livraria Cruz. 1962.

30. FRANÇA LH, SOARES NE. A importância das relą̧ões intergeracionais na quebra dos preconceitos sobre a velhice. In: Terceira idade: desafios para o terceiro milênio. 1997. 
31. FREITAS MCS. Uma abordagem fenomenológica da fome. Campinas. Rev. Nutr. 2002; vol.15 no. 1 .

32. GLES TR. História do existencialismo e da fenomenologia. SP: EPU, Ed. da Universidade de São Paulo, 1975.

33. GOMES WB. The Phenomenological Interview and the Study of Concious Experience. Psicologia USP 1997; 8(2): 305-336.

34. GONÇALVES LHT et al. Rede de apoio comunitário à família do idoso. Revista de Ciências da Saúde, Florianópolis, 1990; 9 (1): 86-101.

35. GRINBERG L, LANGER M, RODRIGUÉ E. Psicoterapia de grupo - Enfoque psicanalitico. Trad. de HR FLEURY, VMM CARDOSO. RJ: ForenseUniversitária. 1976.

36. GUINSBURG J. Evreinov e o teatro da vida. Folha de São Paulo: São Paulo, 1981 maio 31: (folhetim).

37. HAGEDORN R. Fundamentos da prática em terapia ocupacional. Trad. José Batista. São Paulo: Dynamis editorial; 1999.

38. HEIDEGGER M. Sobre a essência do fundamento; a determinação do ser do ente segundo Leibniz; Hegel e os gregos. São Paulo: Livraria Duas Cidades, 1971.

39. HEIDEGGER M. Seminário de Zollikon / Martin Heidegger. São Paulo: EDUC; RJ, Petrópolis: Vozes, 2001.

40. HEIDEGGER M. Ser e Tempo. Petrópolis: Editora vozes, 2002. v.1 e 2.

41. JASPERS K. Psicopatologia geral. SP: Artes Médicas. 1985. 
42. JÚNIOR AS, NETTO MRL. Depressão na Terceira Idade; apresentação clínica e abordagem terapêtutica. São Paulo: Lemos, 1992.

43. KALACHE A et al. O envelhecimento da população mundial: um desafio novo. Rev. Saude Pública 1987; 21(3): 200-10.

44. KOUDELA ID. Brecht: um jogo de aprendizagem. São Paulo: Perspectiva: editora da Universidade de São Paulo. - (coleção estudos; 117); 1991.

45. LEFÈVRE F, LEFÈVRE AMC. O discurso do sujeito, coletivo: um novo enfoque em pesquisa qualitativa (desdobramentos) Caxias do Sul, RS: EDUCS, 2003.

46. LEGER JM, TESSIER JF, MOUTY MD. Psicopatologia do envelhecimento: assistência às pessoas idosas. Petrópolis: Editora Vozes, 1994.

47. LIMA LJC, PASETCHNY N. Atividades em grupo: uma alternativa para inclusão social na terceira idade. Rev. Ter. Ocup. Univ. São Paulo 1998; 9(1): $37-42$.

48. LOPES J. Pega teatro. Campinas, SP: Papirus, 1989.

49. MAGALHÃES DN. A invenção social da velhice. Rio de Janeiro: Papagaio. 1989.

50. MARTINS J, BICUDO, MAV. A pesquisa qualitativa em psicologia: fundamentos e recursos básicos. São Paulo: Editora Moraes/EDUC, 1994.

51. MARTINS J, BICUDO, MAV. Um seminário arançado em fenomenologia. São Paulo: EDUC, 1997. 
52. MARZANO S. Teatro: mirante da ventura humana- Processo de definição da teatroterapia. 1996; [Dissertação de Mestrado - Instituto de Psicologia da USP].

53. MELO LL. Do vivendo para brincar ao brincando para viver: o desvelar da criança com câncer em tratamento ambulatorial na brinquedoteca. 2003; [Tese de Doutorado - Escola de Enfermagem da USP de Ribeirão Preto].

54. MINAYO MCS. O desafio do conhecimento. Pesquisa qualitativa em saude. $2^{*}$ ed. São Paulo-Rio de Janeiro: Hucitec-Abrasco, 1993.

55. MINISTÉRIO DA SAÚDE. Fundação Oswaldo Cruz. Informação, educação e comunicação. Promoção da Saúde: Carta de Ottawa, Declaração de Adelaide, Declaração de Sundsvall, Declaração de Bogotá. Brasília, 1996.

56. MONTEIRO PP. Envelhecer: histórias, encontros, transformações. Belo Horizonte: Autêntica, 2001.

57. MORAGAS R. Gerontologia social: envelhecimento e qualidade de vida. São Paulo: Paulinas, 1997.

58. MORENO JL. Fundamentos de la sociometria. Buenos Aires: Editorial Paidos, 1972.

59. MORENO Л. Fundamentos do psicodrama. São Paulo: Summus Editorial, 1983.

60. MORENO JL. O teatro da espontaneidade. São Paulo: Summus Editorial, 1984.

61. NERI AL. (Org). Psicologia do envelhecimento: temas selecionados na perspectivas do curso de vida. Campinas, SP: Papirus, 1993. (Coleção Viva Idade). 
62. NERI AL. (Org). Qualidade de vida e idade madura. Campinas, SP: Papirus, 1995. (Coleção Viva Idade).

63. OLIEVESTEIN C. O nascimento da velhice. Trad. de Viviane Ribeiro. SP: EDUSC, 2001.

64. OSÓRIO LC et al. Grupoterapia hoje. Porto Alegre-RS: Artes médicas. 1986.

65. PAVARINI SCI. Dependência comportamental na velhice: uma análise do cuidado prestado ao idoso institucionalizado. SP; 1996. [Tese de Doutorado Universidade Estadual de Campinas, Faculdade de Educação].

66. ORGANIZAÇÃO PANAMERICANA DE SAÚDE. 25.. Conferência samitária pan-americana $\left(50^{\circ}\right.$ sessão do comitê regional). Washington, $\mathrm{DC}, 1998$.

67. PEREIRA IMTB, PENTEADO RZ, MARCELO VC. Promoção da saúde e educação em saúde: uma parceria saudável. O Mundo da Saíde. 2000; São Paulo, ano $24,24(1)$.

68. PESSINI L. Envelhecimento e saúde: Ecos da II Assembléia Mundial sobre o envelhecimento. O Mundo da Saíde. 2002; São Paulo, ano 26, 26(4).

69. RAMOS LR. et al. Perfil do idoso em área metropolitana na região sudeste do Brasil: resultados de inquérito domiciliar. Rev. Saúde Pública 1993; 27(2):87-94.

70. RODRIGUES RAP, MARQUES S, FABRICIO SCC. Envelhecimento, saúde e doença. Arq. Geriatr. Gerontol. 2000; 4(1): 15-20.

71. RIBEIRO JP. Gestalt-terapia: refazendo um caminho. São Paulo: Summus editorial, 1985. 
72. RUBINI C. O conceito de papel no psicodrama. Jornal Existencial [on line] 2000; $[23$ screens]. Disponivel em <URL: http://www.existencialismo.org.br/jornalexistencia/rubiniconceito.htm $>[2002$ Mar 09].

73. SALGADO MA. Velhice, uma nova questão social. São Paulo: SESC-CETI, 1980, p. 124.(Biblioteca Cientifica-SESC - série $3^{\mathrm{a}}$. Idade).

74. SANTIN S. Perspectivas na visão da corporeidade. In: MOREIRA WW. Educação Física e esportes: perspectivas para o século XXI. Campinas, SP: Papirus, 1993.

75. SCHROOTS JJF. Theoretical developments in the psycology of aging. Gerontologist. 1996; 36: 742-748.

76. SPOLIN V. O jogo teatral no livro do diretor. SP: Editora Perspectiva AS. 2001.

77. UNIVERSIDADE FEDERAL DE SÃO CARLOS, Curso de Graduação em Terapia Ocupacional. Catálogo Geral: 1996. São Carlos/SP, 1996.

78. VERAS RP et. al. Terceira Idade: um envelhecimento digno para o cidadão do futuro. Rio de Janeiro: Relume-Dumará, 1995. 
ANEXOS 


\section{ANEXO 1}

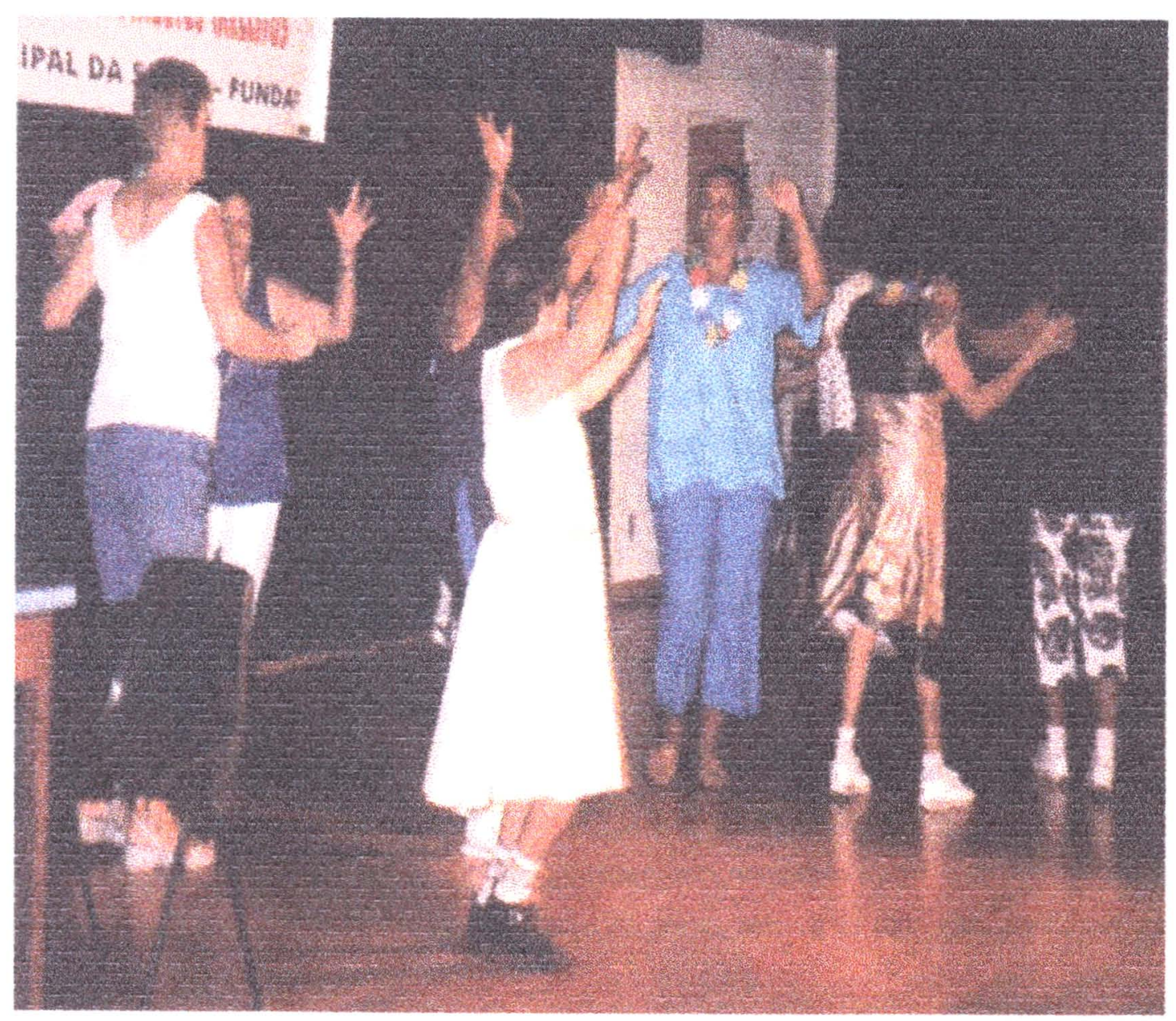

Descrição dos Encontros 


\section{DESCRIÇÃO DOS ENCONTROS}

\section{PRIMEIRO ENCONTRO}

Data:11/11/2002 Horário: 8:00 às 9:00 horas

Coordenadoras: CC (colaboradora de terapia ocupacional) e ACS (Fonoaudióloga)

Em 11/11/2002 (CC e ACS) fizeram o primeiro contato com o grupo de pacientes do Programa de Hipertensão Arterial e Diabetes Mellitus do bairro Simioni da Unidade Básica e Distrital de Saúde (UDBS), com a finalidade de apresentação da proposta de trabalho que se pretende desenvolver. Esta consiste na formação de um grupo com caráter terapêutico, que terá como recurso o teatro espontâneo do cotidiano, criado a partir das próprias falas e do cotidiano das pessoas do grupo. Este trabalho será coordenado por mịm e terá como colaboradoras a fonoaudióloga ACS, e a estagiária do quarto ano de terapia ocupacional CC, que contará com a supervisora de estágio optativo em Hipertensão Arterial e Diabetes Mellitus (que tem uma interface junto a esse grupo expressivo em teatro), a terapeuta ocupacional LUF que participa indiretamente das atividades do grupo dando apoio teórico em questões concernentes ao estágio em Terapia Ocupacional de CC.

Neste primeiro encontro não estive presente, mas orientei as colaboradoras no tocante ao direcionamento das atividades, considerando relevante a exposição deste primeiro relato.

Foi proposta como atividade inicial uma dinâmica de apresentação, na qual solicitouse que cada um dos integrantes do grupo falasse seu nome, o que mais gosta de fazer, o que menos gosta de fazer no seu dia-a-dia e uma fruta que os representasse

O objetivo desta atividade foi propiciar uma interação entre o grupo a fim de conhecer um pouco de cada um dos membros do grupo, através de suas falas e preferências, dando início ao trabalho de expressão.

\section{ATIVDADES DESENVOLVDDAS}

Haviam no total 21 participantes no grupo, todas mulheres. Uma das participantes referiu que fazer teatro sempre foi o sonho dela desde criança e perguntou se agora ela iria conseguir realizar este sonho.

Todas expressaram verbalmente muita vontade em fazer parte desta nova proposta de trabalho. 
Quanto à dinâmica de apresentação o próprio grupo sugeriu que cada uma que fosse se apresentar subisse em um tablado (uma espécie de palco existente no local em que se reúnem) para falar o que foi sugerido.

Foi uma experiência muito rica que suscitou muitos conteúdos emotivos e o grupo como um todo acolheu as necessidades e os desabafos trazidos durante a apresentação, trazendo dados de realidades que elas vivenciam em seus cotidianos.

A seguir segue um breve resumo do que foi relatado por cada uma das participantes do grupo.

- NM.

Gosta muito de fazer bordado e crochê. Gosta de praticamente tudo do que faz. Não especificou aquilo que não gosta. Fruta que a representa: Laranja.

- $\underline{E E}$.

Gosta de tudo, principalmente de cozinhar. Os filhos são o que mais a deixa feliz. Adora as amigas do grupo da $3^{2}$. idade. Não gosta de enxugar a louça .Fruta que a representa: Banana.

- IC.

Gosta muito de bordar. Não gosta que chamem sua atenção na frente dos outros .Fruta que a representa : Abacaxi.

- TS.

Gosta muito de cozinhar, dançar, se divertir. Não gosta da doença. Fruta que a representa: Uva.

- MA.

Gosta de estar na turma da $3^{\mathbf{a}}$. idade, gosta de cantar e adora assobiar. Considera-se uma pessoa alegre, não gosta da tristeza. Também não gosta de passar roupa ("eu nunca dou conta"). A mensagem que ela deixa para o grupo é: "todos devem ser muito otimistas e acreditar que tudo vai melhorar, ser alegre, lutar pelo que quer, vencer e acreditar" Fruta que a representa: Banana.

- EB. ("sou parente do bispo" risos...)

Gosta muito de dançar e adora passar roupa. Não gosta da falta de dinheiro. Não aceita a morte. Odeia cozinhar. Fruta que a representa: Uva.

- IM.

Adora dançar, passear e brincar com esta turma da terceira idade. Gosta muito de macarrão Não gosta de limpar o fogão. Fruta que a representa: Caqui.

- $\underline{F S}$. 
Adora fazer bolachinhas (casadinhos). Estava bastante desanimada ao falar e chegou a chorar, pois falou sobre sua filha que está doente. Sofre de depressão. $O$ grupo todo a acolheu neste momento dizendo que ela pode contar com todo o apoio das amigas. Francisca também comentou sobre suas dificuldades vivenciadas no seu cotidiano como não ter ninguém que a ajude a cuidar da filha, entre outras coisas. Fruta que a representa: Mamão.

- $\underline{\text { TSS }}$.

Adora passear, dançar se divertir. Não gosta da tristeza. Fruta que a representa: Abacate.

- JM.

Gosta de fazer seu serviço de casa tudo direitinho. É participando deste grupo que ela sente-se bem. Não gosta de tristeza e quando fica muito preocupada com o filho que sai e não avisa para onde vai e volta só de madrugada. Fruta que a representa: Caqui.

- ED.

"Minha vida são meus filhos". "Não tenho muito tempo disponível para participar deste grupo". Acredita não ser uma pessoa triste, considera-se muito feliz. Fruta que a representa: Maçã.

- $\quad$ MCS. (os participantes brincaram: "Ela é parente do Lula")

Gosta muito de passear, dançar, namorar. Vai sempre aos bailes. Anda sempre maquiada e bem arrumada. Adora se pintar. Tristeza é ter problemas com os filhos. Considera que esta turma acabou com sua tristeza. "Esta turma me anima muito". Fruta que a representa: Pêra.

\section{- $\underline{\mathrm{ACS}}$.}

Gosta muito de estar com a familia toda reunida. Não gosta de mentiras. Fruta que a representa: Amora.

- $\underline{\text { GS. }}$

Gosta muito de passear para bem longe, de preferência para ficar alguns dias fora. Sua maior tristeza é quando os filhos estão desempregados. Fruta que a representa: Pêra

- MRV.

Sua tristeza é ficar longe dos filhos que mora em Roraima (já chegou a ficar 4 anos sem ver o filho). A mensagem que ela deixa para o grupo: "Sejam bondosas de coração, o bem que a gente deseja para a gente é bom desejar para todos." Gosta muito de fazer todo o serviço de casa ouvindo uma boa música. Considera o grupo muito importante, pois ela sente-se muito bem aqui neste espaço junto com suas amigas. Fruta que a representa: Banana nanica. 
Gosta muito de limpar a casa. Não gosta quando falta água. Mensagem para o grupo: “continuem do jeito que estão pois estão muito bem e felizes." Fruta que a representa: Pêra.

- MLF.

Gosta do dia da ginástica para fazer esta bagunça gostosa. Sente tristeza quando quer atenção das pessoas e estas na dão. (As demais integrantes do grupo disseram que ela é muito carente, gosta muito de atenção)Ela gosta muito das amigas quando abrem uma "portinha" para ela fazer esta bagunça junto com todo mundo. Fruta que a representa: Manga.

- $\underline{\text { OMS. }}$

Gosta de passar roupa, dançar, passear. (Passear é o que mais gosta de fazer). Não gosta quando a sua irmã ( que também participa do grupo não deixa ela ir passear). Ela gosta de todas suas amigas desse grupo da terceira idade. Fruta que a representa: Pêra.

- FAC.

Gosta muito de fazer ginástica, dançar, pular, etc. Antes de vir aqui era muito tímida, mas hoje já está bem mais animada e descontraida (dançou até a dança do ventre). Antes não gostava de conversar com ninguém. Sente muita alegria em vir aqui para a ginástica. Gosta de dançar. Não gosta da doença. Fruta que a representa: Maçã.

- MAA.

"Alegria é estar no meio deste pessoal". Gosta também de estudar na escola noturna. Tristeza quando está doente ou alguém da família adoece. Fruta que a representa: Manga.

- PB.

Gosto das reuniões de familia (tem 6 filhos e 16 netos), gosta de festa e da casa cheia. Tristeza: perda de um filho há 10 anos (suicídio). Considera este grupo muito importante, gosta muito das amigas aqui deste grupo. Lamenta não ter muito tempo para participar. Gosta muito de andar e fazer compras. Fruta que a representa: Uva.

\section{Consideracões:}

Este foi o primeiro encontro com este grupo. Foi colocado que a partir do que elas trazem como vivências dos seus cotidianos, coisas que gostam, ou o que não gostam de fazer, e as necessidades e desejos apresentados, é que serão realizadas as "peças de teatro". A importância de trazer o teatro para a área da saúde, é poder questionar e representar o que de certo modo incomoda estas pessoas ou as deixam tristes e doentes. Desta forma, o teatro toma-se terapêutico.

Este grupo foi muito acolhedor e receptivo. Foi possivel perceber uma grande adesão na proposta deste trabalho. 


\section{SEGUNDO ENCONTRO}

Data:18/11/2002 Horário: 9:00 às 9:40 horas

Coordenadoras: CC (Estagiária de terapia ocupacional) e ACS (Fonoaudióloga)

Total de participantes: 18 pessoas, $E E, I C, A C S, J M, M A, F A C, I M, N M, L T B, O M S, E B, T S$, LOV, IDC, MLF, GS, ACS, TSS.

Neste encontro ainda não participei, mas orientei as colaboradoras no sentido de comunicar o meu início para a semana seguinte. Este encontro teve a finalidade de dar continuidade ao trabalho iniciado na semana anterior.

Inicialmente as profissionais estabeleceram com os participantes a questão do horário que funcionará este grupo expressivo. Foram dadas duas opções ao grupo (por conta da disponibilidade de horário da pesquisadora que tem que se deslocar de outra cidade): permanecer às segundas-feiras após a aula de ginástica, ou seja das 9:00 às 10:30, ou mudar para as terças-feiras das 14:00 às 15:30. O grupo deu preferência para as terças-feiras no periodo da tarde. Desta forma, combinou-se o horário que acontecerá este grupo.

\section{ATIVIDADES DESENVOLVIDAS}

Primeiramente foi perguntado quais pessoas não estavam na semana anterior, onde foi feita uma rápida apresentação dos participantes do grupo e incluíram os nomes destas pessoas na dinâmica que seria realizada neste encontro.

Foi proposto ao grupo que cada um dos participantes retirasse de uma sacola um pequeno pedaço de papel contendo um nome de uma das pessoas que presentes neste grupo.

Esta dinâmica teve como proposta estimular a dramatização através da representação do outro, ou se preferisse, de representar a si mesmo. Uma forma de interação e percepção de "como o outro me vê e me representa".

Esta dinâmica objetivou descontrair e desinibir os participantes para poder iniciar a proposta de dramatização do cotidiano

Todas foram muito participativas, imitavam o jeito da pessoa andar, falar, e as mais timidas, apenas com palavras, falavam um pouco sobre como é a pessoa que elas sortearam.

Este grupo novamente foi muito receptivo e participativo. É possivel perceber a grande animação desta turma. Foi um momento de grande descontração e risadas. As participantes interagiram bem, algumas sendo bastante criativas no modo de representar suas colegas, às vezes, de forma bastante engraçada. 


\section{TERCEIRO ENCONTRO}

\section{Data:26/11/2002 Horário: 14:00 às 16:15 horas}

\section{Coordenadora: MPC Colaboradoras: CC e ACS}

Total de participantes, 11 pessoas: $N M, M C S ., M R V$., MAA., MLF., NM, TS, OMS, EE, EBe GS.

Após as apresentações, discutimos sobre as caracteristicas deste grupo que será um grupo aberto, podendo entrar ou sair participantes de acordo com o interesse de cada um deles, e que os próximos encontros, durante um periodo que poderia ser variável de quatro a seis meses, será utilizado para compor a coleta de dados da Tese que desenvolvo na Faculdade de Saúde Pública da USP-SP, se assim os membros do grupo acordarem, falei sobre a proposta do trabalho e da necessidade de oficializarmos a participação de cada um através de um termo de consentimento livre e esclarecido, que deveria ser preenchido e assinado por aqueles que concordarem em participar da pesquisa.

Em um segundo momento, foi perguntado ao grupo quem gostava de teatro, muitas não sabiam o que viria a ser um teatro e outras logo informaram que não gostavam, segue abaixo o que foi comentado por algumas participantes deste grupo em resposta à proposta do teatro:

NM: Eu não gosto de teatro

MRV: Eu nunca assisti uma peça de teatro

TS: Não posso falar se gosto ou não gosto, pois nunca vi um teatro

\section{ATIVIDADES DESENVOLVIDAS}

Logo em seguida então, foi sugerido um aquecimento com a utilização de exercícios de respiração e exercícios físicos, com a finalidade de conscientização corporal e relaxamento, visando relaxar as musculaturas do corpo e se soltar um pouco mais . Fizemos várias caretas, deixando o corpo bem a vontade, propondo movimentos bem soltos e relaxados.

Depois foi sugerido que as participantes do grupo andassem utilizando todo o espaço disponivel. Seriam três tipos diferentes de andar: Câmera lenta, normal e muito rápido. Ao encontrar qualquer colega do grupo teria que olhar nos olhos dela, fixar o olhar e depois continuar andando conforme orientações sobre o ritmo do andar, buscando manter seriedade proposital. Isto foi um pouco dificil pois elas olhavam uma para outra e davam muitas risadas. 
Em seguida dividiu-se 0 grupo em dois sub-grupos com o mesmo número de participantes em cada um deles, um em frente para o outro. Um deles iria contar uma história muito alegre utilizando somente gestos e expressões faciais e a outra participante iria dar muita risada. Depois inverteu os papéis, quem contou a história agora ia ouvir e expressar muita tristeza, pois a outra colega iria representar através de gestos e expressões faciais uma história muito triste. Poucas participantes conseguiram fazer expressão de tristeza pois a maioria deu muita risada.

Ainda como aquecimento, todos os participantes voltaram a ficar unidos e novamente deu-se continuidade na atividade de caminhar pelo espaço, desta vez, ao encontrar uma colega iriamos falar uma língua muito enrolada (exercício denominado bláblá-ção, nos laboratórios teatrais), onde ninguém iria entender nada que era falado, apenas utilizando para a expressão, os gestos e a entonação de voz.

Para finalizar este aquecimento e iniciar a segunda etapa do trabalho, foi proposta às participantes fazerem uma roda e solicitado que elas recordassem algumas cantigas de roda e começassem a brincar. Várias participantes lembraram uma série de cantigas e isto trouxe muita motivação uma vez que proporcionou muita descontração e envolvimento das participantes neste momento de brincar.

Encerrada esta parte, orientou-se que os participantes sentassem em um círculo e iniciou-se uma outra etapa do trabalho, na qual foi lançada a seguinte questão:

"o que significa o envelhecer para você? “

A seguir seguem os depoimentos que foram obtidos com esta pergunta.

\section{NM: Velhice é ficar com a pele enrugada}

TS: Ter o cabelo branco

MA: Envelhecer está na cabeça

EE: Envelhecer é a doença. Não me sinto velha com 72 anos.

NM: Eu não me sinto velha, mas não sei o que os outros acham de mim.

Não me sinto véia, pois até brincamos de roda hoje. Eé depois dos quarenta que a mulher é mais mulher. Eu não penso em envelhecer. Não me sinto veia pois vou alcançar ter um tataraneto

EE: Ah!! Não gosto de ter neto. Não aceitei e não aceito envelhecer. Tenho bisnetos, mas não quero que me chamem de Bisa, avó eu até que tive que aceitar. Eu tenho dez netos e me sinto muito orgulhosa

MLF: Velhice é as pessoas caducando.

TSS: Não queria ser jovem nesta época de hoje. Minha época de jovem foi muito boa. Hoje em dia não dá para confiar nesta juventude. Quando era jovem tinha as praças, os homens e as mulheres ficavam circulando de um lado para o outro. Hoje não tem mais confiança. 
GS: Não ligo que me chamem de veia. Outro dia no ônibus, um rapaz virou para o outro e disse: "Não vou dá lugar para esta veia não!!". Eu dei risada e achei graça. Sou veia mesmo fazer o $q u \hat{e} ! !$

LTB: Quando nós fazia ginástica lá na praça, um rapaz falou: "Nossa! Abriu a porta do cemitério" e eu respondi: Abriu mesmo, seu pai e sua mãe devem estar vindo aí atrás e você que só bebe e fuma logo logo também entrar para o cemitério!

TS: Outro dia eu também estava no ônibus e um cara segurou a passagem e disse que era para eu pular por cima. Eu respondi: óia, se fosse para eu passar por cima todos deveriam ter pulado, porque todo mundo que passou usou a roleta? Em seguida ela explicou que ele estava falando com ela daquela maneira, pois ela nunca arregalou os dentes para ele. Nunca deu bola para ele.

Diante destes depoimentos resolveu-se encenar um trajeto de ônibus retomando algumas falas que foram trazidas.

Ao definir os papéis algumas resolveram ser os jovens que mexiam com as senhoras de idade.

EE: Eu vou ser jovem, pois não gosto de ser veia

MLF: Jovem

LTB: Motorista

Combinou-se que iria começar a encenação e retomar a fala de TS que o cara falou para ela pular por cima. A coordenadora MPC foi este cara.

TS se enfureceu e disse: Você está falando assim comigo, porque nunca te dei bola, eu não arreganho os dentes para você!

Existia a provocação por parte do cara representado por Márcia e TS retrucava: Não te dou bola porque sou uma mulher casada e o senhor também é casado, eu conheço sua esposa e gostaria de mais respeito.

Em seguida, reproduziram o que havia acontecido com GS, dos rapazes não quererem dar o lugar para ela. Desta vez ela reagiu e disse para as pessoas que representavam os jovens: Veia é a avó de vocês, eu não quero sentar não, pois daqui a pouco eu vou descer. Muito obrigada, seu sem educação!

Várias pessoas encenavam algum acontecimento que vinha na cabeça e elas se divertiam muito e falavam o que vinham na cabeça, sem qualquer tipo de censura.

Foi criada uma situação em que Márcia entrava no ônibus e provocava todas as senhoras. Elas ficaram muito nervosas e respondiam à altura, colocando-se como pessoas que mereciam todo direito ao respeito.

O motorista (representado neste momento, por ACS) também provocava as senhoras e elas respondiam: $\hat{O}$ seu motorista, você está carregando gente e não animal. Dá para o senhor ir devagar. Um dia o senhor ainda vai ter a idade que nós temos e quero ver o senhor chegar lá. Aposto 
que não vai ter esta disposição que temos, nós dançamos, fazemos ginástica, nos divertimos, entre outras coisas que eu duvido que você vai agüentar.

Finalizou-se esta etapa e todos inclusive os profissionais sentaram fazendo um círculo. Foi perguntado para as participantes o que elas haviam achado deste tipo de trabalho e mais uma vez foi lançada a questão do que significa envelhecer para elas. Logo abaixo está o que cada uma respondeu e deixou como depoimento:

MLF: Não pensei que fosse tão bom. Porque não trouxeram a filmadora?!!.

EB: Envelhecer é muito ruim. Queria ficar sempre nova. Não queira envelhecer. As pernas vão ficando fraca. Eu adorei o trabalho, gostei de tudo, foi ótimo. Ótimo mesmo...

EE: Adorei, julgava ser tão diferente. Achei muito bonito. Todas as amigas foram muito legais. Envelhecer é muito triste. Não quero envelhecer. Quero ir como eu estou indo. Ahh Credo!! Não consigo mais subir em um banco. Ihh! Estou ficando veia. Eu que subia em goiabeira, laranjeira, hoje não consigo subir em um banco. Fico muito triste de não conseguir.

TS: Envelhecer é ser muito teimosa. Viver contrariada com tudo, a tristeza. Isto sim é envelhecer. Eu não gosto de envelhecer. Tudo que eu faço é com satisfação. Tenho saúde graças a Deus. Eu adorei tudo, embora eu pensei que a gente fosse rolar no chão, deitar e dançar. Foi tudo ótimo.

MAA: Envelhecer é muito ruim, é triste. Perde as forças. Não consigo mais subir em lugar alto, mas eu ainda cuido da comida, lavo e passo roupa. Cuido de um jardim lindo que tenho. Hoje para mim foi ótimo. Não pensava que fosse tão bom assim, do jeito que foi.

OMS: Não agüento subir nas coisas. Vai indo agente vai se acostumando. Gostei da brincadeira, gostei da ginástica inicial.

GS: Gostei muito do jeito que foi hoje. Não me sinto veia. Gosto de dançar, brincar, passe. Não reclamo de dor. Aonde me chamam eu vou. Adorei a brincadeira de roda. Me senti criança.

LTB: Não pensava em ser motorista de ônibus para carregar esta velharada. Nunca pensei em envelhecer. Vou levando. Na gincana eu subi até em caminhão. Velha é o pensamento da pessoa. Hoje eu fui fazer um exame e encontrei um médico morenão bonitão... Eu achei isto tudo maravilhoso. Agente se sente criança.

MLF: Gostei das brincadeiras, da ginástica, do cobrador de ônibus. Envelhecer é se entregar, se abandonar, é não se aprontar, não se divertir. Eu não fazia isto. Eu ficava muito triste, estava entrando em depressão. Hoje já estou bem melhor. Fui até para Santos passear com minhas amigas aqui do grupo da terceira idade.

Gostei muito das brincadeiras. Lembro das brincadeiras e fico cantando. Pensei que fosse muito dificil. Pensei comigo: Será que eu vou passar vergonha!!!

MRV: Velhice é tristeza. Sou muito apegada com minha familia. Depois que eu vim para este grupo eu melhorei bastante. Minha sobrinha já percebeu que eu estou até parecendo mais jovem. 
Falar a pura verdade, eu adorei as brincadeiras. Me apeguei muito a vocês, mais amigas para o meu lado.

MA: Gostei muito. Adorei. Velhice é não se arrumar, não se cuidar. Depois que eu vim para a ginástica eu melhorei muito. Aqui tenho este pessoal como minhas irmãs. Gostei muito do que vocês fizeram.

NM: Envelhecer é quando não puder mais andar e trabalhar. Foi muito bom. Não esperava isto tudo. Gostei muito.

NM: Eu gostei. A gente se divirtiu bastante. Quero que continue sempre assim. Envelhecer é ficar muito pensativa com as coisas, $A$ velhice é natureza. Todos envelhecem.

Para fechar este encontro, foi feito um grande círculo com as mãos dadas e todas foram convidadas a pensar em um nome para este grupo, depois de algumas sugestões o grupo escolheu o nome: "alegria de viver" e fizemos um tipo de "grito de guerra", levantando as mãos dadas e desta forma finalizou este encontro.

Ao confirmar o próximo grupo para a próxima Terça-feira, o grupo informou que haverá um passeio ao clube neste dia e por este motivo não seria possivel que o grupo acontecesse, desta forma, após discussão com as participantes, optamos em realizar o grupo expressivo na Segunda-feira depois da aula de educação física. Todos concordaram e combinaram do grupo iniciar por volta das dez horas, pois virei de ônibus de São Carlos e conseguirei chegar aqui em Ribeirão Preto, mais ou menos neste horário.

As participantes também informaram que na Segunda-feira elas programaram um café da manhã e seria legal que as coordenadoras do grupo expressivo-teatro também participassem.

\section{QUARTO ENCONTRO}

\section{Data:02/12/2002 Horário: 10:00 às 11:30 horas}

\section{Coordenadora: MPC Colaboradoras: CC e ACS}

Este grupo aconteceu excepcionalmente na Segunda-feira, conforme foi esclarecido no relatório do grupo anterior. Participaram deste grupo: GS, MCS, MLF, OMS, NMS, MAA e TSS.

Aconteceram alguns imprevistos neste grupo que comprometeram a dinâmica do mesmo. Primeiro, o café da manhã que foi combinado na semana anterior não aconteceu, as participantes na última aula de ginástica (sexta-feira) decidiram cancelar este café da manhã, no entanto algumas participantes não compareceram nesta aula e não ficaram sabendo da 
decisão do grupo, desta forma, algumas pessoas (apenas três) prepararam o que comer e o que beber para hoje e sentiram-se constrangidas pois não sabiam que este café da manhã havia sido cancelado. Segundo, o ônibus que eu estava vindo atrasou e só foi possivel que chegar ao local que acontece o grupo às 10:40 horas e muitas das participantes resolveram ir embora, acreditando que eu não viesse mais, pois a ginástica encerrou antes das 9:00 horas e todas ficaram esperando. Alguns exercícios com a utilização da música foram feitos como: dança, brincadeira de roda, entre outros. Estes exercicios foram coordenados pela estagiária de terapia ocupacional CC, enquanto aguardava a minha chegada e a da ACS que foi me buscar na rodoviária.

Após nossa o grupo, imediatamente, teve início e como foi sugestão do próprio grupo filmar os encontros, hoje isto aconteceu pois trouxe a pela primeira vez, a filmadora.

\section{ATIVIDADES DESENVOLVIDAS}

Exercícios de movimentação global, relaxamento e coordenação motora.

JOGOS DRAMÁTICOS: Imaginar um objeto e passar para o seguinte;

$1^{0}$ - bola grande. Uma côr para a bola, pulseira, brinco, mala. Expressão corporal com objeto imaginário.

JOGOS DE INTERAÇÃO GRUPAL: Duro / Mole. Robô, mole, normal - cumprimentar. Abraço. Brincadeira dos números (intensidade de emoção graduando da meiguice à raiva). Brincadeira do detetive.

(OMS escreveu uma carta sobre a velhice - transcrita abaixo)

\section{Um dia nós vamos ficar velhos}

E nós precisamos aproveitar

Bastante a vida até quando velhos

Ir à ginástica, baile, passear com os amigos,

A familia faz parte da nossa vida,

Com o apoio dos filhos,

Assim, podemos suportar a tristeza, a alegria, a a dor, e o medo.

Zelar pela saúde e envelhecer

Sofrimento inimigo da velhice são as doenças cardiovascular.

O envelhecer não é doença, velhice é uma coisa que ninguém quer Ter,

Com o passar do tempo todos nós temos,

Precisamos de carinho, paciència, compreensão a todos,

As pessoas idosas é possivel envelhecer feliz com saúde 
Pessoas viviam até 60 anos, agora até $75,80,85$ anos sem tantos sofrimentos. Inimigos da velhice são doenças cardiovasculares

Apoio familiar ajuda a superar a dor, tristeza e o medo.Zelar pela saúde e envelhecer feliz

Velhice tem que aproveitar, dançar, passar, viajar, divertir bastante até quando puder

Coordenadora: $O$ que significa o envelhecer prá vocês?

MAA: Eu acho que envelhecer, no meu ponto de vista, faz parte da vida, é uma vida que ocê já fez aquilo tudo que tinha que fazer quando era nova, eu acho que faz parte da vida tudo aqueles anos. Eu acho que ervelhecer faz parte, com saúde, porque todos nós vamos chegar numa idade.

Coordenadora: Como é para você?

MAA: Eu acho bão, hoje na minha idade, tudo que eu tô vivendo com as minhas amigas.

Coordenadora: O que é bom?

MAA: Na minha idade, esses passeio, essas coisa que vocês faz prá gente, essas menina que tá sempre arrumando passeio, fazendo as coisa, eu acho muito bão, na minha idade, na idade que nós tamos aqui. Admiro muito essas que tem mais idade que eu, que fica sempre ali, eu não sei se a GS, e a MCS são da minha idade, mas elas fazem ginástica.

Alguém do grupo pergunta:- Quantos anos você tem?

MAA: 57 anos.

Coordenadora: $\dot{E}$ assim que você se sente?

MAA: Eu me sinto bem, por causa disso aí, antes de eu entrar aqui, eu não era assim. Eu era assim, por exemplo: meu marido é muito caseiro ele não gosta de sair, ele falova assim "eu não vou", eu também não ia, eu ficava muita em casa, eu não ia em lugar nenhum, agora não, ele fala que não vai, eu falo assim: eu tô indo com as minhas amiga! Sábado teve o baile da terceira idade, eu fui com meu filho, a vizinha, e a filha dela que é novinha, eles foram comigo, algumas colegas daqui colegas foram! $A$ L. que tá aqui foi, a T.... Então eu acho importante para nós na nossa idade, não é, na nossa idade, isso que tá acontecendo é muito bom, esse pique que arrumaram para nós, eu não sei quem arrumou, mas é muito bom. É assim que eu sinto.

MCS: Eu acho que...no tempo da terceira idade é que eu tô vivendo... No tempo que eu era moça eu não vivia...

MAA: Eu também não!

MCS: Agora é que eu acho que tô vivendo, é agora que eu tô vivendo, também agora, eu não sou velha! No tempo que eu era moça mesmo, não aproveitei nada, nada, então, agora não, agora eu tô aproveitando a minha vida, tô fazendo tudo aquilo que eu não fiz, agora eu tô fazendo, eu me sinto tão feliz! Eu vou dançar, agora, vou namorar, precisa ver o que eu arrumo agora, no meio dos amigos lá no baile. Agora eu tenho amigos prá poder rir, prá poder viver. a gente conversa muito, a gente dança, porque eu sei que agora, eu dei um passo na minha vida, tao melhor agora, precisa de ver que delicia! 
Coordenadora: $O$ que você acha que envelhece?

MCS: Acho que preocupação né!?

Esses dias eu tava me achando meio decaida, assim né?! Dai eu disse: preciso dar um jeito nesse rosto. Ai eu passei um batom, arrumei meu cabelo...Dai minha menina falou assim: " minha mãe não anda boa de jeito nenhum, ainda bem que a minha mãe passou um batom"...eu respondi: "é porque vocês não tão acostumado que eu não passo batom, porque eu já levanto, passo batom, jả me arrumo, passo creme...Teve um dia que eu tava meio assim, né! Não tava me arrumando nada..eles ficaram me olhando: "parece que a mãe não tá boa?!" "não tô mesmo!" Ontem já fui no baile de novo. conversei bastante, ri bastante, ishi! Parece que eu voltei outra de la', ontem! Eu tô aproveitando muito é agora, na minha terceira idade, porque antes eu não aproveitei. Porque as coisas que vocês faz prá gente é uma grande coisa.

(as outras pessoas do grupo concordam verbalmente nesse momento)

Muito bom, fim-de-ano a gente daquelas idas no Bosque...

MAA: é muito bom, mesmo! Fim-de-ano a gente tem aquela ida no Bosque, é muito bom...

MCS: menina, esse ano eu perdi aquele negócio da CAVA, parece que eu fiquei ruim de manhã cedo, achando que eu ia prô negócio da CAVA. Eu levanto 5 horas prá começar a arrumar prá gente ir, esse ano eu não fui, parece que eu fiquei perdida dentro de casa, a gente tá acostumada a se virá assim com as mulheres, todas saem, eu fiquei assim...

MAA: aqui nós somo assim, sabe! $\dot{E}$ um grupo, nós somos unida, quando um fica doente, a gente faz visita, a gente somos muito unida aqui, Graças a Deus! Eu não tenho o que reclamar de ninguém.

MCS: o sobrinho dela me chamou prá eu desfilar na quinta-feira, eu não fui porque eu não tova boa, como é que eu ia desfilar com a cara que eu tava? Não tinha jeito. Acabei não indo, eu desfilei prô sobrinho dela no ano passado, esse ano perdi.

Coordenadora: foi ruim perder?

MCS: Foi horrivel, a gente acostuma demais com as coisa, depois fica perdida.

MAA: prá mim tá sendo ótimo. Agora essas menina trouxe uma outra atividade melhor ainda né? Nós só tem que agradecer, porque isso que ela trouxe ai prá nós foi muito bom, ela e amiga dela, foi muito bom.

Coordenadora: MCS., quantos anos você tem?

MCS: Nos meus documentos, quando eu nasci, ninguém me registrou, eu fui criada em Altinópolis, por uns fazendeiros. Dai eles quiseram me casar e eu não sabia o que era casamento, eles pegaram, foram no cartório e me registraram e não falaram nada. Eles foram no cartório e me registraram, no meus documentos eu tô com 70 anos.

TSS: Mas quantos anos cê tem, setenta, C.?

MCS: É nos meus documentos eu tô com setenta anos, mas eu tenho sessenta e seis. Eles registraram por conta disseram prá mim: "Cê tem que casar com esse moço, porque ele é aqui da fazenda". Eu não sabia o que era casamento, marcaram o dia do casamento, levaram na igreja...eu 
não sabia porque minha patroa não me falou nada, eu só andava por ali na fazenda. Levaram na igreja, casou eu nem sabia como é que dormia com um homem, eu não sabia de nada.

Coordenadora: Você teve que aprender?

MCS: É ué!

Coordenadora: $E$ ele era bom?

MCS: Nunca ninguém me falou. Naquele tempo era tudo guardadinho. Não conversava sobre esse assunto. Hoje não, meus netos conversa esses assunto comigo, nós conversa, nós ri, falamos besteira.

TSS: Hoje não tem nada guardado, não!

MCS: Minha netinha de 7 anos chega perto de mim e diz: "Vó cê vai no baile hoje?" Vou. "Vó cê tá tão linda, vai linda mesmo, prá você arranjar um namorado, prá você beijar na boca. A senhora tem que aproveitar tua vida". $\dot{E}$ assim que eles falam prá mim hoje. Quando naquele tempo agente conversava com alguém disso? O que dirá separar, não se falava nisso.

Coordenadora: Efoi bom o casamento?

MCS: Foi horroroso!

Coordenadora: E prá você GS.?

GS: Eu aceitar a velhice? acho que quando a pessoa não aceita ela fica ranzinza, fica impertinente eu já tenho visto isso! AAí essa música alta!!

Eu já morei perto de gente que tava assim com uns 60 anos, ai abaixa esse volume no rádio, gritava perto de mim. Eu não me importo com o rádio alto, com conversinha... Sábado nós fomos lá no Bonfim. Fui ver minha neta, ela foi dançar, dança de rua, minha nora já não tava agüentando mais, aquele arto falante, aquele povo falando e olha que ela é nova né! 43 anos parece que ela tem. Então a senhora não importa? Falei não! Eu ainda brinquei com ela, "cê tá ficando velha"! (risos). Porque eu não ligo, já morei perto de escola, a mulher mudou e eu fui morar lá na casa dela, ela mudou por causa das crianças, ela não tova agüentando ela tinha 68 anos, naquele tempo, eu tinha uns 27, ai ela falou prá mim, "porque cê é nova", falei não... E hoje as crianças brincam comigo, eu posso ouvir grito de criança, música, baile. Prá mim a velhice é ficá aceitando, esperando a morte. Eu tenho uma irmã que ela tá com 70 anos, ela não sai, cê sabe que ela deu derrame, deu derrame, mas ela trabalha, como é que ela não pode sair? Ela tá esperando a morte. E a morte tá esperando ela. (risos) Meu pai fazia nois trabalhá muito não deixava ir em baile, num deixava, tinha horário prá voltá. aí casei também com uma pessoa que eu não gostava, eu gostava era de outro, mas casei com aquele lá, nél Porque o outro eu vi namorando uma moça, eu morava na roça tão ingênua, boba, eu pensava que ele ficava aqui em Ribeirão quietinho, ai um dia eu falei prá ele que eu não ia na Festa da Lapa, ele chegou de mão dada com uma moça, minha mãe não queria nem vê o casamento ai eu desiludi dele! A minha mãe fez eu casá com um rapaz que ela gostova muito dai eu casei, ele me deu 2 filhos maravilhosos, meus dois filhos é muito bom, mas brigava muito ai eu xingava ele mesmo, falava prá eu não sair, eu saia, eu vendia, eu gostava de muito de vender, até hoje eu gosto, eu saia prá vender depois que eu soube que ele tava desenganado, dai eu parei em casa, ai eu pensei: vai que esse trem morre ai eu tô na rua, eu ia prá Pontal... Um dia eu fui prá Pontal 3 dia, meu filho disse que vinha 
comigo, na hora, minha nora que ela é muito assim (gesto) disse eu não vou, falei vai! Porque se eu chegá em casa sozinha ai vou escutar né, dai cheguei com eles os netos, ai ele foi abraçar os netos, $e$ até esqueceu. Meu filho me trouxe de carro. Ai até esqueceu de mim eu não ligava prá ele, ele não ligava prá mim, a gente teve 4 filhos já pensou se ligasse?!

Depois quando ele morreu eu até chorei muito...Um companheiro..., chorei tanto terrivel, né. Tinha hora que ele tava bem, tinha hora que ele bebia muito, quando ele bebia precisava aguentá. Sei lá, a velhice acho que é aceitar, se você não aceitar a velhice, se você não aceitar, envelhece mesmo, eu tenho essa minha irmã, que ela fala assim: "eu não aceito".

Ai é um custeio, o fliho dela tirou uma fotografia no computador e ela nem quis ver, ela tinha 29 anos, ela não gosta nem de ver a fotografia, era muito linda, assim como você, muito bonita mesmo, ai eu falei "Ceara" quem te viu, quem te vè hein? (risos)

Então eu acho que ela não tá aceitando a velhice e eu aceito da maneira que for eu aceito, passeio, agora cada vez tem programa melhor prá nós, que nem esse programa que cê tá fazendo (teatro) prá nós tá uma beleza, né! Tá sendo muito bom, eu gosto demais. Vamos ver se o ano que vem nós tamos juntas outra vez (risos).

Eu vô na biodança hoje às 2 horas.

TSS: Eu já fui velha, mandei ela tudo prá trás, já faz 9 anos eu tô me sentindo jovem.

Coordenadora: Por quê você era velha antes?

TSS: Porque na época era um tal de sofrimento, cuidar de filhos, marido não gostava de passear, era aquela "clamidade" de tudo, um dia você tinha uma roupinha outro dia cê não tinha um calçado, e vivia aquela "vida chutada" aconteceu tudo, ele morreu, eu fiquei com meus filhos, tudo solteiro ainda, só tinha um casado e eu fui cada dia me desgastando, cada dia me desgastando, aí levei uns 2 anos ainda esse desgaste na minha vida, andava prá rua chorando, encontrava um tava chorando, encontrava outro dizia que eu tava demolindo minha vida, ai uma amiga minha falou prá mim assim: "vai procurar a ginástica, você vai, fica lá, vai sará dessas coisinhas", ai vim, achei esse negócio aqui, fiquei, tô aqui hoje graças a Deus! Ai eu fui me levantando, levantando e graças a Deus, hoje eu acho bem eu "no ar", me sinto mais cheia de força, cheia de alegria, não tenho mais aquela tristeza que eu sentia, antes, né, eu safri bastante, muito mesmo! E hoje graças a Deus, por isso é que eu falo, eu já fui véia lá no passado, lá prá trás, hoje eu tô me sentindo uma pessoa realizada das força que eu tenho hoje, graças a Deus. E vamo levando a vida, né gosto de um bailinho, gosto de passear, nós temos nossos passeios de fim-de-ano, nóis diverte bastante, né l., nóis faz a caminhada, de vez em quando aparece um paquera, andava choramingando pros canto, agora anda cheio de paquera, verdade, hoje me sinto assim como eu tô falando, eu me sinto mesmo gente, óis, me sinto mesmo uma pessoa nova, hoje cheia de vida, cheia de "tudo" hoje Porque um tempo atrás eu me sentia eu quase no lixo, despencada, mas graças a Deus, hoje eu tô espertinha, passeio, né, cuido das minhas coisas numa boa, tenho um neto que eu crio, ele tá com 16 anos, vou fazê meus passeio, mas eu deixo as coisas prá ele tudo, em cima, é comida, é isso, é tudo, ele não tem nada que reclamá de mim, e vou prôs meus passeio, vou-me prô churrasco prá piscina, e 
nóis lá vai, que là vai (gesticulando com os braços) se Deus quisé (em gesto de prece) Ele protege bastante nóis.

Coordenadora: E prá você L.?

LTB: A velhice prá mim...Eu sempre falo assim: não quero saber de nada! Todos esses tempos eu sofri demais. Às vezes eu penso, assim ah! a gente dá bola prás coisas que passa nervoso lá em casa, dá eu não vou ligar pr'essas coisas, porque quem vai se acabar sou eu, então eu jogo prá trás? Faço ginástica, tem meus amigos.

Eu era assim muito acanhada, nossa quando eu comecei a ginástica, eu ficava assim queitinha, num canto, ficava assim esperando as pessoas conversá comigo, porque se não conversá comigo eu não conversava, não conversava de jeito nenhum

(MCS afirma que ela não conversava de jeito nenhum)

aí num dia desses ninguém conversava comigo, fazia ginástica e ia embora, aí um dia a $C$. coordenadora, me chamou para eu ir num passeio, eu fiquei muito contente, ai então eu vô participá desse passeio, porque eu não sabia o que era diverti, passeá, nada, antes eu era muito fechada, ai ela falou assim, ó, nós vamos nos divertir, vamos brincar, alegrar, né sair, ai eu comecei, qdo fala de passeio eu (gesticulando d a mão e sorrindo, a voz mais clara forte saindo p/frente) eu vou mesmo ?? eu vou batendo a asa, eu faço a festa, eu danço, eu faço ginástica dentro da água, (risos) ai acabô (abaixa o tom de voz) aquelas coisa de ficá assim, a gente se acabando, cheio de problema, então eu acho que tem maisé que se divertir.

OMS: Eu acho que a velhice os filhos tem que tê cuidado c/ os pais, deixar os pais passear, $e$ não falar que é velho, tem que aproveitar a vida, não ligar prô que os filhos falam, sair, e passear, não dar bola para que os filhos falam.

Coordenadora: $O$ que os filhos falam?

OMS: $\dot{A} s$ vezes falam $p^{\prime}$ os pais não sair, não ir ao baile

Coordenadora: Mas porque eles falam p/ não sair?

OMS: É porquê, às vezes um acha, que às vezes, tá muito velho então não vai, não tem companhia para ir, então não vai, então fica em casa.

GS: $A$ irmã da OMS é a NMS, em casa é solteira nós fomos 6 feira no teatro de Arena ela foi comigo, eu falei dá licença $N$, ah a irmã falou, cuidado c/ essa menina.

"Essa menina"(risos). Ela (NMS) tem ciume dela

Ela tem muito cuidado.

Nesse dia a gente onze e meia, tava tudo lá fora esperando, ela foi lá em casa prá eu vê se ia, ai ela falou assim, cuidado cl essa menina (riso gerais) ai minha netinha de 10 anos tova lá em casa nem liguei p/neta, eu falei menina, cadê a menina? Só se for a menina do olho!"

Coordenadora: $E$ você se sente uma menina assim?

Eu não! Elas que falam

GS: Ela tem 51 anos! Elas falam uma menina de 51 anos!

Não sei porque ela é caçula... não sou (OMS) não (outras falam) Ela tem algum problema, labirintite é problema? 
GS: Ah! Problema, e ishi ela faz tudo, dança twiste...

(OUTRAS): Ela toma remédi.o

Elas (irmãs) acham que ela tem problema né?

Desde que a conheço eles acha que ela é doente

Eles que põe doença em mim

Coordenadora: Vc se sente doente?

(OUTRAS) Ishi! Eu não ela faz tudo, ela vai dançar o Twist, dançou o Twisty com nóis lá..

\section{QUINTO ENCONTRO}

Data:10/12/2002 Horário: 14:00 as 16:15 horas

Coordenadora: MPC Colaboradoras: CC e ACS

Participaram deste grupo as seguintes pessoas: NM, MLF, OMS, MCS, LTB, EE, TS, TSS, GS, EB, NMS.

Os exercícios de aquecimento consistiram em respirar fundo em pé, alongamento de pernas e corpo todo. Alongamento dois a dois - puxando os braços altemadamente de frente - de costas - puxando pelos braços- "taping" no corpo todo, exercicios de coordenação bater palmas e no corpo - "brincadeira do lenço atrás" e exercícios de aquecimento facial da garganta e aquecimento da voz, coordenados por ACS.

A seguir foi proposta a brincadeira do espelho, que consistiu na formação de duplas e uma de cada vez fez o papel do "espelho" que imitava todos os gestos e expressões faciais feitos pela outra participante da dupla, após experienciar o papel de espelho ocorria a troca de papéis entre as duplas. Um outro exercicio para manter a sintonia entre as participantes foi a realização de um outro exercício que ficou denominado como "a energia das mãos", mantendo as mesmas duplas, as participantes deveriam imaginar a existência de um fio invisível entre as mãos que conduziam os movimentos das mãos simultaneamente entre as duplas. Este exercício foi bastante interessante pois permitiu a exploração de movimentos talvez nunca antes explorados e as participantes ficaram impressionadas com a sensação de que existia uma energia entre as mãos e faziam com as mãos entrasse em uma sincronia. Esta atividade teve uma boa participação do grupo.

Após estes exercícios de aquecimento, fiz uma explicação e demonstração a respeito sobre as mímicas, e em seguida solicitei ao grupo para que cada uma das participantes através da mímica representasse tudo que faz para preparem-se para dormir e inclusive 0 dormir. Informei que ao acordarem elas iriam se encontrar em uma Unidade de Saúde (esta proposta surgiu pela conversa inicial), local onde iria dar início à encenação. Sugeri que elas 
poderiam exagerar e explorar tudo que não gostam na unidade de saúde onde elas freqüentam, atravès da utilização do teatro.

As participantes acolheram bem a proposta de fazer a mímica, muitas fingiam dormir encostadas nos pilares ou mesmo no chão, mas ao representarem a unidade de saúde foi difícil elas entrarem em cena, sendo necessário que eu fizesse alguns direcionamentos e sugestões.

O grupo conseguiu expressar-se bem quando era apenas para conversar e dizer o que elas acham do serviço de saúde que freqüentam e se há algum atendimento especial para as pessoas idosas neste serviço e como isto funciona para cada uma delas. Quando foi aberta a discussão todas as participantes queriam falar sobre algum acontecimento pessoal e várias situações foram abordadas como: a conduta dos médicos com as pessoas idosas, o tempo de espera para as consultas e a demora para conseguir agendar uma consulta, alguns casos de falta de respeito com as pessoas idosas, entre outras coisas. Uma médica foi bastante citada, várias pessoas contaram algum fato que já aconteceu com esta médica envolvendo familiares como: filhos, esposos, entre outros.

Esta conversa foi bastante rica e trouxe uma série de temas que podem ser futuramente melhor abordados.

Ao finalizar, foi mais uma vez foi colocada a pergunta orientadora:

“Qual o significado do envelhecer para você?"

Cena da UBS. Personagens:

Médico, Atendente,,Enfermeira, Paciente (em fila), Recepcionista, Médico plantonista e cardiologista.

Paciente 1 (Pctel) chega com dor.

Recepcionista (Recep): - Vem aqui comigo! O que é que você tem?

Pctel: - Dor de barriga, porque bebi muita água.

Recep: - Então a senhora vai passar por um médico. Vai sente aí.

Pctel: - Ai ai ai, a minha barriga está doendo!...

Médico: - Então a senhora toma esse remedinho aqui.

Pctel: - Só isso doutor? Eu posso ficar a noite com dor de barriga.

Médico: - Não! tudo bem. Ë só tomar esse remedinho.

Pctel: - Se amanha doer eu volto doutor.

Médico: - Tudo bem. Pode vir que depois eu receito...

Pcte1: - Tá bom doutor. Brigado. (volta para o lugar)

Paciente 2 (Pcte2). 
Recep: - Vem Maria, vamos engessar teu braço!

Pcte2: - Vamos lá (levanta e entra no consultório).

Rec (o que você tem? Quebrou o braço? Vem senta e fala pro médico - crise do tosse na recepcionista. Crise de risos.

Muda de recepcionista. Entra plantonista (coordenadora)

Entra nova paciente (Pcte3)

Médico: - O próximo! Qual o seu nome?

Pcte3: - Maria.

Médico: - O que a senhora tem?

Pcte3: - Acho que estou grávida.

Médico: - Tome esse remedinho aqui! É impossivel que a senhora esteje grávida! Quantos anos a senhora tem?

Pcte3: - Tenho 80 anos.

Médico: - Não! vou mandar a senhora para o médico. Não, a senhora tem que ir para um médico especialista. Vou mandar a senhora para o médico... A senhora precisa de um médico?

Pcte3: - Preciso.

Médico: - Tem um médico bom ali. Outro dia a senhora volta, tá bom?

Pcte3: - Tá bom. Ah que bom!

Médico: - O próximo!

Paciente 4 (Pcte4) (aos pulos e gritos): - Sou cu, sou eu!! Doutor levei um tiro! Ai, ai... levei um tiro.

Médico: - É urgente aqui! O que se faz agora?! Chama a ambulância..

(ouve-se a sirene)

Médico: - O próximo! encerrou! Ninguém mandou demorar, volta amanha

Pacientes (Pctes) reclamando: - "que isso!!" "é assim, sempre tem que agendar" "é assim desse jeito!"

Na sala de espera, o que não se gosta, cada uma com uma queixa no PA - pronto atendimento, pronto socorro, ambulatório, posto de saúde...

- "gente, que demora! faz duas horas que chega e esse troco não desocupa. A gente perde hora, o médico que não atende, enfermeiro que não vem... Eu tô com as minhas pernas doendo, doendo, doendo, faz massagem, "faz não sei o que"

- Declaram todos ao mesmo tempo!!! Motivo: demora no atendimento.

- "chega de esperar gente, que horror. Cida vamos embora! Viemos fazer o que aqui?"

Enfermeira (Enf): - Chegou, chegou!! Eu sou a enfermeira e estou pintado as minhas unhas agora!

Pctes: - "enfermeira pintando as unhas." Enfermeira estou aqui desde as 11 horas."

Enf: - Oh, não posso fazer nada!

Pctes (algumas se levantam, se aproximam da enfermeira, começam a andar, voltam a se sentar, falam uma com as outras ansiosas): - "ah não! O que é isso!!" "ta todo mundo ocupado." “... com a canela toda ardida" "tô aqui desde meio-dia, o que é isso?" "vamo chamá o "Clube Verdade!" "é o técnico que não vem!" "o médico que não vem!" 
Pctes (com expressão de alegria e batendo palmas): - "Ah! Chegou o médico gente, chegou o médico!" "Vamos ver se ele atende agora!" "Agora vai ter que atender todo mundo!" "Vai ter que atender todo mundo!"

Repórter do "Clube Verdade" - Porquê vocês chamaram o "Clube Verdade"?

Pctes: - "Porque eles não atendem ninguém. Nóis tá aqui desde manha..." "nóis tá com fome, com sede e não pode sair daqui" "tem gente que fica comendo ai" "as crianças chorando também! Não tem como esse posto ser assim desse jeito" "a enfermeira só pintando as unhas" “..... então manda a enfermeira embora!"

Enf: - Não tem nada prá fazer aqui. Eu não...

Pctes: - "A enfermeira vê se pode!" "A enfermeira só fica pintando as unhas" "É vê se pode" "O pátio esta imundo"!

Repórter: - Vocês sempre vêm a este posto?

Pctes: - "Sempre! (em coro)" "É o posto do nosso bairro" "Eu dependo desse posto" "Sempre vim e sempre sofrendo desse jeito assim" "Aqui não tem nem papel higiênico!" "Não tem"

Enf: - O quê!!?? Não tem papel higiênico?

Pctes: - "Não tem! (em coro) não tem nada!"

Enf: - Mas cadê o papel higiênico que a gente comprou?

Pctes: - "Não tem bebedouro de água gelada, tem que pegar água da torneira. Essa água de torneira sabe lá..., uma porcaria..." "Não tem papel higiênico" "Não tem nada! Tá uma sujeira!" "Não tem remédio"

Repórter: - E a espera é muita?

Pctes: - "A espera? Demais da conta, não tem quantidade. Tô ai o dia inteiro esperando um médico e ele ainda não veio o dia inteiro. Ó, eu estou aqui desde às 11 horas da manha, eu tenho roupa para lavar, tenho tudo o que fazer e o doutor não chega... e eu num tô muito legal não. (risos) Minha perna dói muito só de andar. Eu to doida para ir prô banheiro, até tô com vontade de correr e não posso. $O$ médico não dá licença. (gesticula as mãos, movimenta a perna dolorida)."

Enf: - Vocês só reclamam. Falam de barriga cheia. Tem serviço de casa e ainđa reclamam...

Pctes: - "Olha aqui porque não é você...tá bom?" "e a enfermeira toda bonitinha..." "toda folgada" "porque não é você que está com esse barrigão, e o meu filho vai nascer, oh! (expressando corporalmente a forma de um barrigão) tá aí ó, meu filho já vai nascer e você não faz nada"

Enf: - Mas o que eu posso fazer, eu não sou médico!

Pctes: - "Mas eu tô com dor, eu quero ir pro hospital não interessa." "Vai lá na maca, o que é que você tá esperando?" "Vai lá na maca e mata todo mundo que vai lá, mata mãe e filho."

Enf: - Eu não sou médica e se ele não vir mais...

Pctes: - "..... Já vai embora." "Agora fica a senhora sentada ai ó..." "A enfermeira não pode ficar sentada ai desse jeito não. Não dá atendimento prá ninguém. Não atrás do médico."

Enf: - Vocês reclamam de barriga cheia.

Pcte: - "Ela fica ai toda bonitinha, não faz nada do que tem que fazer."

Enf: - Porque vocês não vão lavar roupa hein. 
Pcte: - "Tão mandando a gente prá casa."

Enf: - Fazer comida, vocês só vem aqui prá fazer fofoca na fila.

Pctes: - "Nóis tudo têm que tratar da pressão" "somos tudo hipertensos" "acabou o posto, já fechou!" "nóis já veio, não atendeu. Nóis já vai embora" "e cadê o remédio?" “o médico já falou que outro dia nóis volta de novo."

Enf: - $O$ médico tá aqui agora.

Médico: - Enfermeira, chame esse pessoal, mede a pressão de quem tá aí, vamos terminar logo o nosso trabalho.

\section{(GRITOS DE ALEGRIA)}

Enf: - Aconteceu um problema, uma emergência e o médico atrasou, só pode chegar agora.

Pcte: - "Porque não telefonou?"

Enf.: - O celular tava sem bateria.

Pcte: - "Porque não trocou?"

Enf: - Vamos fazer fila prá tirar a pressão.

Pcte: - "Quanto tá minha pressão?"

Enf - Pctel: - $14 \times 12$, tá ótima, pode ir embora.

Enf - Pcte2: - $16 \times 25 \ldots$

(ESPANTO GERAL)

Outros pacientes: - "Ó ela tá morrendo!!"

Enf: - Vamos logo pro médico!!(e vai empurrando)

Médico: - Porque a pressão subiu?

Pcte2: - Comi muita pimenta, por isso subiu a pressão, eu quis comer um bocadinho de pimenta/

Médico: - A senhora tá cansada de saber que não pode comer isso! Sabe o que a senhora vai fazer, vai passar na farmácia e vai ver que remédio tem lá para controlar a pressão. Porque aqui no posto, não tem condições de tratar, tem que procurar assistência médica, porque isso aqui não tem jeito.

Pcte3: - Ai chega na farmácia e não tem nenhum remédio!!

Enf: - Tem outra aqui que tá com a pressão bem alta.

Médico: - A senhora sabe porque que tá com a pressão alta?

Pcte4: - Eu levei um susto.

(O médico entrega a receita e ela vai à farmácia do posto...)

Enquanto isso na farmácia do posto...

Pcte2: - Vim buscar esse remédio!

Atendente: - Não é hora de pegar remédio, a gente só distribui remédio das 9 às 10 horas.

Pcte2: - Mas eu vou ficar sem remédio!?

Atendente: - Não posso fazer nada.

Pcte4: - Eu vim buscar esse remédio.

Atnd: - Não tem esse remédio no posto.

Pcte4: - Oh! O que eu vou fazer???

Outro paciente: - É nunca tem remédio no posto mesmo! 
Atnd - Pcte4: - Aí não é problema meu, não é problema nosso.

Pcte4: - Ta escrito assim, destacado na constituição "negligencia médica da 6 meses a 2 anos de cadeia. (RISOS GERAIS). A gente faz o exame depois demora 6 meses pra ser atendido, ai a diabete já subiu, de 79 vai para 180, porque faz 6 meses que fez o exame e já aconteceu tudo de bom e de ruim e temos que esperar né.

\section{Termina a cena}

Coordenadora (iniciando uma outra proposta): Vamos pensar como seria um bom atendimento!

EB: Não pode faltar remédio jamais, tem que ter bastante médico na hora que a gente chegar, ficar aberto 24 horas por dia, não faltar médico de jeito nenhum, ter dentista, tudo, tudo... tem que ter no posto médico.

Coordenadora: E o que mais?

EB: Os funcionários tem que ter educação, tratar direito as pessoas, ter respeito pelos pacientes.

EE: Tem que ter leito também.

EB: Fui tirar uma radiografia e não tinha.

Várias pessoas falando ao mesmo tempo...

TS: Eu tive um problema na perna, e não podia andar e foram me buscar em casa.

GS: Tem funcionário bom e tem funcionário ruim.

EE: Uma vez a minha filha estava com uma cólica, não menstrual, acho que era nó nas tripas, ai eu levei no HC e internei. Eu não sei o que fizeram nela, mas ela melhorou.

TS: Agora remédio caro não tem mesmo.

EB: Só os baratinho. Os genéricos tá tendo. Remédio caro só tem pra AIDS.

Coordenadora: Quem toma remédio aqui?

EB: Eu tomo 10 comprimidos por dia.

Todas falam ao mesmo tempo...

EE: $O$ que é isso!? É muito remédio!! Eu tomo um só para a pressão.

EB: Uma vez, o posto ficou muito tempo sem cardiologista, abandonado esperando alguém.

$\mathrm{EE}$ : Faz 3 meses que os meus exame tá tudo pronto, parece que agora é que vão me chamar.

Coordenadora: Prá vocês qual seria o melhor tipo de atendimento, como vocês gostariam que fosse.

NM: Que as consultas fossem mais perto umas das outras, demorar seis meses a 1 ano é muito!

LTB: Eu fui em um médico, ele me mandou pra outro médico, tudo no mesmo dia.

NM: Eu tava com uma dor aqui na barriga, fui ao médico, ele passou a receita direto sem me examinar. Ele receitou, e eu não tomei, as veis que acontece isso eu não tomo.

Coordenadora: $E$ como você gostaria que ele te atendesse.

NM: Colocasse a mão, que ele me examinasse com a mão. 
Muitas conversas paralelas...começam a falar da limpeza no nosso posto...: - "tá sempre sujo" "limpeza nota zero" "tinha funcionário mas não limpava" "depois que terceirizou, ficou limpo" "nunca tinha papel no banheiro" "bebedouro nota zero, chão do banheiro, zero"

GS: Nunca tinha material de limpeza, não tinha rodo, nem detergente nem bombril, por isso também não limpavam. Tinha uma funcionaria que começou a levar de casa material de limpeza, vassoura, bombril, detergente, que não tinha no posto. Ai começaram a chamar ela de puxa-saco e ela parou. Olha só cê vê ela tava fazendo um bem.

Coordenadora: Vocês acham que tem tratamento diferente para quem tem mais idade?

GS: Não tem não!

LTB: As pessoas bem de idade, doentes, ficam muito tempo sentadas, da até dó.

NM: A Doutora M trata muito bem.

EE: Eu sei que uma vez eu levei meu marido já falecido que tava doente, ele tova muito ruim mesmo. O médico demorava, demorava. Sei que meu filho foi lá e falou os diabo "meu pai ta ruim, pelo amor de Deus esse médico não atende porque?" ai a enfermeira perguntou quem era o médico dele, e o meu filho respondeu "Ah é o doutor fulano, ta aqui a ficha." A enfermeira pediu para que esperasse mais um pouco... nossa ele comecou a xingar e diser que o pai tava ruim. Ai ele foi chamado.

EE: Eu tava com um problema no tornozelo, ó, eu tenho um mais fino que o outro, dai eu marquei consulta e cai, sem querer com a Dra $M$, dai ela me mandou prô ortopedista, um carniceiro também! Ele nem me examinou, mandou eu andar no consultório e me disse assim: "a sra tem que usar salto!" E eu disse: "o Sr. Não vai me tirar uma radiografia, me mandar fazer algum exame?" Ele disse não, a sra. Tem que usar salto!

Sai de lá louca, com vontade de processar a médico. Fui falar com a Dra Me disse isso prá ela, ela disse que eram uma equipe de médicos! E que se eu quisesse eu tinha que processar toda a equipe d(os 6 médicos) Eu não sou sozinha! Ai ela me mandou consultar um outro - primeira coisa que ele fez foi me mandar tirar uma radiografia!

Pelo amor de Deus! Eu não conhecia nenhum médico e fui procurar a Dra M e tive que passar por isso! Falou prá eu usar salto!

GS: Ai você i a quebrar os dois pés!!!

Eu voltei mais animada

EE: Eu fui à médica tava com uma dor no braço, dai eu falei Dra. Será que isso não é reumatismo, eu faço faxina, passo roupa, mexo com água, ela falou "reumatismo não existe!!" Quando que não existe reumatismo! "Isso não existe" disse ela!

TS: Ele cheirou cola! (risos)

(Coordenadora retomando o diálogo): O que signinifica envelhecer prá você? 
Todas falam ao mesmo tempo - ainda das doenças e dificuldades em relação

NM: É a natureza da gente, é a cabeça, vai chegando os anos, a carne vai ficando fraco a gente vai cansando.

EE: Não sồ velha não, ainda. Olha se a gente continuar com esses médicos aqui do Postinho a gente vai ficar véia mesmo! A gente vai mudar viu, a gente fica nervosa óia! $O$ que aconteceu comigo com os nervos do pé, chegou lá ao invés de me tirar uma radiografia, me mandou andar de salto! Eu falei: "Filho de uma mãe, que carniceiro desgraçado!

EE: Acho que velhice é o que aconteceu comigo hoje eu fiquei chocada fiquei triste: a minha irmã me ligou, "Ah EE vem prá cá nós tamos ficando velha! Faz tempo que nóis não se vê..."

Bom, eu não me sinto velha! (Ela tem 72 eu tenho 74) ela disse nem eu me sinto velha, você vem prá cá nem eu me sinto velha, você tem seu dinheiro, você pode vim, vc entra no ônibus a gente te pega.

Maria não posso. Não me deixam nem ir na ginástica sozinha, tenho que ir acompanhada agora vou para S.P. (sozinha??), não vou Maria.

Eu fiquei tão triste, isso envelhece a pessoa...

GS: Por que ela te chamou de velha?

EE: Não porque ela me chamou de velha não, envelhece porque eu fiquei encucada, sabe! Eu queria ir prá lá mas meus filhos não me deixam ir sozinha, os dois trabalham, não vão perder dia, perder o emprego por causa minha! Eu fiquei assim pensativa: Puxa eu podia ir...

NM: Por quê você tem algum problema, de viagem de quê?

EE: O único problema que eu tenho é labirintite! Mas eles não deixa! De jeito nenhum!

Coordenadora: $O$ que eles falam? $O$ que eles te dizem que não te deixam ir por quê?

EE: Ah! Eles pensam que eu não consigo, é só por causa da labirintite, meu Deus do céu acontece tanta coisa, muita coisa. Tanto bandido no ônibus...

EB: Ah! Isso não! Eu vou para qualquer lugar sozinha!

(outras também discordam)

EE: Eu morro de medo, viu!

O único lugar que eu sai sozinha foi prá Santos, não sozinha, fui com minha turma da ginástica. Mas o meu filho foi conversar que a nossa supervisora a D. Cida. Falou assim " $D$. Cida, eu vou deixar a minha mãe sob sua responsabilidade, não deixa acontecer nada com ela não".

EB: $O$ que é isso? Eu vou prá todo lugar, os meus filho demora prá me achar.

LTB: Eu pelejei prá jogar ela no mar!

EE: Então é isso, agora prá São Paulo, eles não me deixa ir, não adianta. Eu tinha vontade de ir..., Eu também não tenho coragem de ir sozinha. Envelhece é você ficar pensando nisso dai, e não poder fazer o que quer... Se você puder fazer tudo o que você quer, você tá vivendo, agora eu não posso fazer tudo o que eu quero.

TS: $A$ gente não pode é pensar na velhice $A$ gente não pode ficar falando da velhice, se a gente ficar falando que tá velho, tá velho, a gente fica velho mesmo. Então cê tem que esquecer dela, faze de conta que não existe velhice. Tem que ficar numa boa. 
EB: Eu também não alembro nem da morte, nem da velhice

TS: Não pode ficar pensando mesmo.

LTB: Vocês não quer ficar velho né, então cês põe a camisa do Santos e torce prô Santos! Ninguém vai ficar velho!

(risos)

(todas falam ao mesmo tempo)

Coordenadora: E prá você qual o sentido do envelhecer?

LTB: Ter sempre aquela idéia de jovem, viver a vida, tem que passear, viver, brincar, tudo o que não viveu prá trás vai vivendo prá frente. Eu participo em tudo eu venho na ginástica, eu vou na Igreja, eu onde me chamam eu vou.

NM: Viver não é passear não é aproveitar a vida.

LTB: Eu acho que tudo da cabeça. A pessoa que põe na cabeça eu tô doente, eu tô véia, é assim que vai acontecer. É tudo da cabeça!

NM: Eu acho que a velhice é da natureza, porque vai chegando o tempo, vai passando os anos, esse corpo prá fica diferente dos 20 anos, eu sei que deve ser da dos tempo, conforme vai passando os tempo, cê vai mudando uai!

LTB: (colocando as mãos no corpo) você vai engordando aqui, caindo aqui é pelanca em todo lugar. O negócio é não ficar pensando é viver a vida, curtir a natureza, viajar...

Se eu acordar de manhã e ficar assim (se curva prá frente) "Ah! Eu não tenho dinheiro, meu pagamento não deu. Se meu pagamento não deu, se não deu amém ?... já acabou o dinheiro mesmo! Uma hora eu peço fiado aqui e vou me virando... não ligo, vou vivendo

Agora a mãe de D. Maura só fica reclamando a pensão da mãe dela é quase 600 paus, a filha manda mais 200 reais prá SP mais uns titulo no valor de 180 reais, a pensão do marido ganha uns 500 reais, a outra filha manda mais uns 200 reais, e ela diz que o dinheiro não dá!

(todas se espantam)

Reclama 24 horas por dia, porque eu não tenho dinheiro, porque eu não tenho dinheiro, tem gente que não tem nada, ela tem tudo e ela não vive! É só reclamação Então quando ela entra na minha casa reclamando eu dou um jeito de sair fora

Coordenadora: $E$ prá você $M L F$ ?

MLF: Bom, ficar velha nós tamos ficando mas só que nós não pode se entregar

Coordenadora: O que é se entregar prá você?

MLF: Ah! Quando a gente vai ao médico, a gente fica nervosa como eu tava um tempo atrás.

EE: Tadinha ela tava tão aborrecida

MLF: Então eu pensei assim: eu acho que eu tô me acabando! Então eu larguei tudo prá lá. $\dot{E}$ isso ail Só que a gente não pode desanimar tem que passear curtir

Coordenadora: Vocês sentem que estão ficando velhas?

LTB: Eu não tô! Tô falando que eu não tô.

EE: Eu não tô velha, de jeito maneira! Sô tão esperta prá trabalhar. Eu faço minhas coisa, eu faço salgado, eu faço doce, eu faço tanta coisa, eu me viro 
(todas falam ao mesmo tempo)

NM: Não tem nada a ver a idade, porque eu tenho 74 anos! Eu tenho ânimo prá fazer tudo, se eu fosse velha eu não fazia tudo o que eu faço!

LTB: Eu acordo cedo às 7 da manhã, fico acordada até meia-noite, sô tão animada eu não me sinto velha

MCS: Eu acho que eu não sô velha

Coordenadora: Por quê acha que não tá velha?

MCS: Porque no tempo que eu era moça eu não fazia nada e agora eu tô fazendo tudo. Eu tô passeando, eu tô andando hoje, eu tenho muita amizade, eu danço, eu paquero os homens no baile eu tenho tanta amizade. Tem um paquera que liga lá em casa. De uns tempos prá cá eu não páro em casa.

Andaram ligando prá mim lá em casa, agora eu tenho que ligar prá ele. Ele ligou lá em casa, eu disse "cheguei agora em casa e tô saindo de novo, mais tarde eu te ligo". Meu genro perguntou quem era no telefone eu disse que era um amigo, ele perguntou "que amigo"? Um namorado meu mesmo.

EE: Olha ela fala mesmo!

(outras concordam, é isso ai)

NM: É genro, né? Se fosse filho ainda vá lá, né?

MCS: Agora eu tô fazendo as coisas que eu não fazia, que eu não podia fazer, então, agora eu tô vivendo!

Coordenadora: Vocês se entreolhando, vocês acham que alguém é velho aqui?

Todas: eu não acho!

EE: $A M G$ (que não estava presente) eu acho que ela envelheceu! Olhando prá ela, eu acho!

LTB: Aquela outra $M$ quando entrou na ginástica, parecia sim, dava até dó, quando ela entrou na ginástica, ela amarrava assim o cabelo, eu falava: nossa como ela é esquisita! De repente ela soltou a franga! Ela começou a se arrumar, ela se arruma ela põe bermuda,? até os filho dela viram!

EE: Ela vivia com gaze amarrada nas pernas, era muito esquisito! Dai ela mudou! Ela sarou.

NM: Ela andava com as saia no tornozelo, é crente, né!

TS: Mas agora ela se largou de novo! né C, parece que ela se largou de novo!

EE: Agora a G aM G tá se acabando, tá envelhecendo!

LTB: Ela tá envelhecendo!

TS: Também ela não gosta de conversar! Ninguém tá conversando com ela. (por isso que tá envelhecendo)

LTB: Ela ficava dependendo dos filhos prá tudo, e vinha reclamá, eu dizia pára com isso! Ela vinha chorando, reclamando eu dizia pára com isso!

$\mathrm{EE}: \dot{E}$ que ela depende dos filhos...

NM: Eu acho que 2 anos atrás eu tava mais velha que agora.

LTB (para NM): Ela rejuvenesceu 2 anos! 
NM: Às vezes a gente vem na ginástica né, a gente encontra as vizinha na porta fica oiando a gente, será que elas pensam? Que a gente não tem nada prá fazer?

EB: Eu faço o que eu quero da minha vida.

LTB: Com certeza

TS: Eu saio de casa, não vejo se ninguém tá me olhando, eu volto da rua, tô nem ai.ssas ai só ficam prostradas dentro de casa...

Coordenadora: $O$ que acontece com a pessoa que fica prostrada dentro de casa?

NM: Acontece que se a pessoa não tem amizade com ninguém, não conversa, fica chocando, não tem divertimento, dai a velhice toma conta

Coordenadora: Que velhice é essa que toma conta?

LTB: Essa pessoa que fica parada lá, pensando na vida lá, só pensando na vida lá! Ai não tenho dinheiro, ai tô com dor no ombro, aí..

Coordenadora: Por quê vocês acham que ela tá envelhecendo? O que tả envelhecendo nela? Por quê ela tá envelhecendo?

LTB: Ah! Primeiro a MG andava sempre arrumadinha, ela saia, ela pintava o cabelo. Ela ia dançar. Ela era prá frente, bonita ai ela parou com tudo.

EE: Ela foi sair da ginástica, ela parou de ir no baile, ela foi se acabando...

NM: Mas ela tem 70 e quantos anos?

EE: Tem nada, ela é nova, ela tem 60 e poucos anos. Véia sou eu e você! (Falou prá NM)

(risos gerais)

NM: Nóis só somo véia na idade!

EE: Pela idade nós somos quase véia

NM: $A$ idade não tem nada à ver! $A$ idade não é véia!

EE: Ela tem 75 anos e tenho 74 ela tem 1 ano a mais que eu olha como nós somos prá frente., nenhuma de nóis é véia!

GS: Você falou uma coisa assim (para NM), uma mulher falou prá mim: "Onde essa mulher vai?" Eu tava saindo prá ginástica, numa Segunda-feira e ela disse assim: "com tanto serviço e a senhora vai sair numa hora dessa?"

Eu respondi: eu não tenho de pedir serviço prá senhora de empregada doméstica!

Ela falou: "Não, desculpa! Eu tô falondo assim porque eu tô com tanto serviço!" Então vai fazer seu serviço, eu disse: eu não tenho serviço, e nem penso em serviço!

LTB: Nem se eu tiver, a hora que eu chego eu faço tudo.

EE: Eu saio prá ginástica eu lavo a louça do café quando chego, porque não gosto de fazer barulho cedo, que a menina dorme, quando eu chego eu lavo tudo

(nesse momento todas contam sobre seus afazeres)

Coordenadora: Vamos encerrando, né? Do que vocês mais gostaram hoje? (nesse momento forma uma roda de mãos dadas)

EE: Eu gostei da mímica, gostei do espelho, gostei de tudo.

LTB: Eu gostei do saquinho, eu gostei da ginástica da mão. 
EB: Eu gostei daquele da mão, é porque a energia passa de uma mão prá outra...

EE: a MLF tá mais triste essa menina.

EB: Falou nem o J. (marido) não me manda mais, eu sou mais eu, eu não faço nada de errado eu entro em qualquer lugar de cabeça erguida e saio, não tenho medo de nada, nem vergonha de nada.

GS: Tá certo!

Coordenadora: Eu acho que a CC (colaboradora-TO), a ACS (colaboradora-fono) e eu estamos aprendendo bastante com vocês.

EB: Eu aprendo bastante com meus filhos.

NM: Sabe porque eu falo que esse trabalho e essas coisas que envelhece, porque eu trabalhei 30 anos de empregada doméstica faz 32 anos que eu tô em Ribeirão Preto, eu lavei roupa e passei faz 30 anos, tinha casa de 10 anos que eu trabalhava, eu pegava 2 ônibus, chegava Ribeirão Preto e pegava outro, quando eu quebrei o braço é que eu parei faz 6 anos...

EE: $A$ senhora vinha de ônibus?

(mais comentários)

Coordenadora pediu para observarem pessoas que elas consideram velhas...

\section{SEXTO ENCONTRO}

\section{Data:21/01/2003 Horário: 14:00 às 16:00 horas}

\section{Coordenadora: MPC Colaboradoras: CC e ACS}

Participaram deste grupo as seguintes pessoas: $M C S, N M S, O M S, M L F, M A A$ (participou pela primeira vez do grupo, tem 58 anos) TS, GS e TSS.

Houve um problema com a fita deste encontro, por ocasião de sua transformação de fita v8 para UHS, onde perdemos boa parte da filmagem.

Iniciando com uma conversa informal com as participantes do grupo, na qual vários assuntos foram abordados como: a questão do envelhecer no dia a dia, com alguns depoimentos vivenciados no cotidiano, a questão do autocuidado, ou seja a importância do cuidar para cada uma delas, pintar o cabelo (esconder os cabelos brancos), arrumar as unhas, disfarçar a velhice, para parecer mais jovem e realçar o visual, entre uma série de outros temas que foram surgindo enquanto esta conversa acontecia.

Depois foram realizados os exercicios de aquecimento. Estes consistiram de alongamentos, esticar os braços como se existisse uma corda pendurada no teto que as puxavam, em seguida, relaxava a musculatura.

O exercício de respiração foi feito, fechando uma das narinas com o dedo indicador, puxava $o$ ar com bastante força e depois fechava a outra narina e soltava o ar pela narina que 
estava fechada anteriormente. Este exercicio foi repetido várias vezes e depois puxava o ar com bastante força com as duas narinas para sentir a diferença.

Foi feita uma auto-massagem no corpo, dando pequenas batidinhas nas pernas, depois foi subindo, até chegar no rosto, onde iniciou fazer carinho no próprio rosto, depois com movimentos circulares com a mão realizou outra massagem no próprio corpo, percorrendo a região do abdômen e das costas. Por último cada uma deu um abraço bem apertado em si mesmas.

O outro exercicio realizado consistiu em andar com um certo molejo e com o comando de um coordenador que sugeria andar como se fosse um gato, muito cauteloso, depois como um elefante, bem pesado, e depois como uma borboleta. Era sugerido que as pessoas tentassem visualizar esta borboleta, distinguindo qual era sua cor, o local onde ela estava, entre outros detalhes, fazendo de conta que voavam. Em um determinado momento era solicitado que elas parassem no lugar e na posição que se encontravam, fechassem os olhos, neste momento, era perguntado a primeira coisa ou imagem que vinha na cabeça. Muitas responderam que pensaram em casa, nos serviços que tinham para fazer, outra se lembrou do filho que mora no Japão, e cada uma foi falando aquilo que vinha a cabeça.

Em seguida, ainda imaginando ser uma borboleta, foi combinado com o grupo que era para eles continuar andando, ou seja "voando" e de repente parar (quando era falado "stop") e pensar em um desejo que gostaria que estivesse acontecido no passado. Após falarem sobre os desejos do passado, continuaram andando e ao mesmo comando- "stop", elas deveriam falar um desejo que gostariam que acontecesse hoje, no presente. Elas comentaram mais sobre os desejos do passado, na qual Tereza I e Neusa, falaram sobre seus desejos de serem enfermeiras; Jenile e Maria comentaram que gostariam de ser professoras; Lourdes desejaria ser cabeleleira e Tereza e Conceição desejariam ser dançarinas e por final Odelcina falou sobre sua vontade de ser bailarina. Sobre o presente, o que elas comentaram foi ter bastante saúde e que os governadores dessem um aumento para as aposentadas, pois o dinheiro não está dando para comprar nada.

Diante do que foi trazido pelas participantes do grupo quanto ao desejo do passado, dividiu-se em sub grupos de acordo com os desejos semelhantes de cada uma delas, para poder discutir e pensar na melhor forma de representar, através do teatro estes desejos. Desta forma ficou: TS e NMS, como enfermeiras, elas fizeram uma encenação, fazendo de conta que estavam em um hospital e cuidavam de doentes, TS fez o papel de paciente e de repente elas improvisaram uma cena de um parto e fizeram detalhadamente todo o procedimento 
para realizar este parto. $O$ grupo todo deu muita risada desta cena e da descontração de TS em fazer o papel da moça que estava para receber o bebê.

Depois, TS e MCS, como queriam ser dançarinas, fizeram uma dança em dupla e as demais participantes fizeram um som parecido com o som de valsa e elas ficaram dançando "pelo salão" e não queriam mais parar. Houve bastante participação de todos nesta cena. OMS por sua vez, dançou como bailarina na ponta dos pés, ela representou como se estivesse em um espetáculo e mais uma vez as participantes do grupo fizeram o coro de fundo para que ela dançasse.

Como cabeleleira, MLF fez sua representação com uma riqueza de detalhes incrivel, ela maquiou e fez escova em TS, cortou o cabelo e tirou a sobrancelha de OMS que disse que estava se amumando para ir ao médico (todas participantes do grupo fazem questão de irem muito bem arrumadas e limpas para o médico. Este assunto apareceu várias vezes neste encontro). MLF com toda delicadeza e precisão fingia passar o batom, maquiar e após terminar de arrumar OMS, o rosto dela mudou, ficou até com um brilho diferente de tanto foi o envolvimento nesta cena.

Para encerrar, foi a vez das professoras, MAA e GS. MAA, como sabe cozinhar muito bem e gosta de fazer isto, uma vez que não estudou o suficiente para ser professora de escola, decidiu fazer o papel de uma professora de culinária. Ela ensinou a fazer um bolo de fubá, todos ficaram com água na boca. GS, quis ser a professora tradicional que ensina a ler e escrever, ela representou muito bem seu papel, colocando muito amor no momento de ensinar. Sua aluna foi a TS, afinal esta fez vários papéis hoje. TS acabou confessando que sempre teve vontade de ser uma atriz muito famosa.

Após todas representarem o seu desejo, foi sugerido que todas se acomodassem umas próximas as outras e contassem o que sentiram ao fazer a representação proposta hoje. Todas comentaram que se sentiram realizadas. Disseram que foi muito bom ter vivenciado personagens que nunca imaginaram que poderiam ser.

Algumas sugestões foram dadas ao grupo para por exemplo, quando forem para alguma festa, pedir que MLF as arrumem, ou mesmo montar um grupo para que MAA possa dar aulas de culinária e assim por diante. Foi um grupo bastante rico, que despertou uma série de sentimentos em cada uma delas. Ao comentarem sobre a velhice disseram que vão levando, levando e que do jeito que está, tá muito bom. 


\section{SÉTIMO ENCONTRO}

Data:28/01/2003 Horário: 14:30 às 16:30 horas

Coordenadora: MPC Colaboradoras: CC e ACS

Participaram as seguintes pessoas: $M L F, T S, T S S, I C$ (participou pela primeira vez deste grupo), $M A A, N M$ e $E E$.

Este grupo teve um toque especial pois as participantes, após a aula de culinária realizada na semana anterior pela MAA, resolveram fazer um lanche da tarde e MAA trouxe o bolo de fubá que havia ensinado em sua aula e as demais trouxeram chás, bolinhos de chuva e café. Incrivel a motivação que foi despertada pelas participantes após o grupo expressivo-teatro do dia (21/01/2003).

Primeiramente, os coordenadores sugeriram que as participantes se posicionassem em circulo e desta forma, iniciou-se alguns exercícios de respiração soltando o ar com bastante força e fazendo um barulho como se fosse um grito e deixando o corpo cair para frente, abaixando a cabeça. Isto foi feito umas cinco vezes. Depois foi solicitado que as participantes puxassem o ar com bastante força pelo nariz e ao soltar o ar pela boca fizessem um barulho com a boca de como estivessem esvaziando um pneu e imaginavam que o ar estivesse saindo pela cabeça, flexionando o tronco para frente.

Depois, foi feito um outro exercício de respiração puxando o ar pelo nariz e fazendo o mesmo barulho do exercicio anterior e ao soltar o ar imaginavam que este ar estava saindo pela perna, levantando-a do chão e cada vez que puxava o ar revezava a perna.

Em seguida, foi sugerido que cada uma das participantes mexessem, parado no lugar todas as partes do corpo, principalmente aquelas que não é comum de movimentar, como: ombros, quadril, cintura. A sugestão era mexer o corpo bem desleixado. Depois, iniciou-se um andar bem a vontade, procurando mexer-se bem. Ainda como exercicios de aquecimento, os coordenadores sugeriram que cada uma das participantes tentasse ocupar o menor lugar possível, e em seguida o maior lugar possivel se expandindo para todos os lados, este exercício foi repetido umas três vezes, procurando se contrair o máximo possível para ocupar o menor lugar, para depois expandir tentando ocupar o maior espaço possível. Ao finalizar esta atividade foi sugerido que as participantes relaxem deixando mãos, braços e pernas bastante leves e soltos.

Um outro exercício proposto consistiu de um coordenador dar um comando que consistia em; falar uma parte do corpo e de duas em duas participantes, aleatoriamente juntavam estas partes. Exemplo: mão direita e as duplas juntavam as mãos direitas. Progressivamente ia juntando mais pessoas com o comando de juntarem uma parte especifica do corpo, passou para juntar de três em três pessoas, depois de quatro em quatro 
até o número igual ao total de participantes, neste momento, o comando foi para que todas juntassem os pés. Formou-se um círculo com todas bem próximas uma das outras e então fazendo movimentos com os pés imaginavam que estavam conversando com os pés, na qual cada um falava o que vinha na cabeça. As participantes deram muitas risadas neste momento.

Depois passou para a encenação, na qual hoje resolveu-se resgatar algumas vivências já realizadas no grupo, como a encenação do ônibus. Dividiu o grupo em dois sub-grupos: um iria representar as senhoras de idade e o outro iria representar os jovens que faltavam com respeito aos idosos, insultando-os, na qual estes idosos teriam que reagir.

$\mathrm{Na}$ encenação do ônibus EE pela primeira vez quis fazer o papel de idosa e disse que ela já está velha mesmo. Quem representou os jovens, não deixava as idosas sentarem no banco e achavam um absurdo toda aquela velharada, além de não pagarem a passagem do ônibus quererem sentar. Consideravam isto muita folga.

A cena foi adquirindo conteúdo, as idosas respondiam à altura para os jovens, dandolhes uma lição de cidadania, referindo ao respeito necessário com o idoso, mas a discussão foi tomando tal forma que houve até briga de uma querer pegar a outra pela provocação que os jovens faziam com as senhoras. Foi necessário até a presença de um policial para poder controlar a discussão e as senhoras de idade conseguiram se defender muito bem, mantendo uma posição determinada para garantir seus direitos.

Para encerrar a discussão o policial, após algum tempo de resistência deu razão às idosas e os jovens desceram do ônibus muito contrariados que continuavam a insultar os idosos.

Como já havia dado o horário, as próprias participantes sinalizaram para encerrar o grupo, pois queriam tomar o café da tarde preparado por elas .

Antes de encerrar, foi solicitado que todas sentassem formando um círculo e houve uma conversa para saber o que as participantes têm achado do grupo, se estão gostando, entre outras coisas. Elas responderam que estão gostando muito e que vir fazer parte deste teatro tem feito muito bem a elas. $O$ exemplo destas falas pode ser verificado com a situação de EE. Ela não estava muito animada para vir para o grupo, na verdade ela não viria, mas TS ligou para ela da igreja e insistiu muito para que ela fosse. Desta forma, ela chegou no grupo sentindo-se muito mal, com tonturas e ela não sabe como conseguiu chegar, ela disse que pensou que iria desmaiar no meio da rua. No entanto, com um pouco mais de calma, EE foi envolvendo-se com as atividades propostas no grupo e sentiu-se muito melhor, não lembrando mais que estava passando mal. 
Ao questionar sobre o envelhecer, EE hoje estava com um discurso diferenciado dos demais dias que participou do grupo, ela referiu-se a velhice como algo ruim, "as pessoas vão se acabando aos poucos", em vários momentos ela se referia à sua irmã que está muito acabada, ela não se conformava na tristeza e magreza que sua irmã está. Ela confessou que ficou chocada ao ver sua irmã daquele jeito. EE havia ido para São Paulo na semana anterior para visitar a irmã e disse que voltou muito mal de lá. EE também comentou sobre seu aniversário de casamento, que havia sido lindo, lembrou-se do marido que já faleceu, enfím , foi um momento dela poder colocar para o grupo um pouco sua vida e seus sentimentos. Falou também que no período de férias, parou com todas as atividades que costuma fazer como: atividade fisica, ir a escola e ao grupo de teatro. Isto tudo estava fazendo muita falta para ela, mas ela ter vindo hoje no grupo havia feito muito bem. Voltaria outra pessoa para a casa, afirmou EE.

IC, como foi a primeira vez que participou do grupo, disse que não pensa na velhice, não se sente velha. Refere estar muito bem, apesar dos problemas de saúde e das dificuldades que enfrenta no dia a dia com o marido. Disse que nunca pintou o cabelo e ainda não apareceu nenhum fio branco em sua cabeça. Embora, já tenha mais de sessenta anos.

Todas falaram um pouco sobre o processo de envelhecer. MCS disse que esta fase tem sido a melhor de sua vida, pois hoje ela faz tudo que não fazia quando era mais nova $\mathrm{e}$ casada. Hoje ela dança, vai a bailes, clubes e está muito feliz. NM disse que é um processo natural da vida e que todos irão envelhecer, mas não pode se fechar e ficar pensando na velhice, tem que ir levando a vida.

Após fazermos o grito do "grupo alegria de viver" com todos de mãos dadas e levantando as mãos ao falar a nome do grupo, todos foram tomar o lanche da tarde preparado pelas participantes.

Antes delas irem embora, conversou-se sobre a possibilidade de acontecer um apresentação no dia 20/02/2003 na formatura das aprimorandas. Elas ficaram um pouco acanhadas e ficaram de pensar, não demonstrando em um primeiro o desejo de apresentar. Foi explicado que este teatro não teria que decorar falas e poderia ser uma cena já vivenciada na situação de grupo. Este teatro poderia retratar o próprio cotidiano das participantes, por este motivo as falas seriam espontâneas. Na próxima semana elas darão a resposta. 


\section{OITAVO ENCONTRO}

Data:04/02/2003. Horário: $14: 30$ as $17: 00$ horas

\section{Coordenadora: MPC Colaboradoras: CC}

Participaram deste grupo as seguintes pessoas: EE, IC, TSS, OMS, MRV, MLF, GS, MCS, TS.

Como exercícios de aquecimento foram feitos um exercício de ritmo e coordenação motora global, depois foi feita a brincadeira do mestre mandou em que cada uma delas faziam um movimento com o corpo, mas não poderia ter movimentos repetidos. Muitas participantes fizeram movimentos já realizados na aula de ginástica. Foram feitos alguns exercicios de respiração, puxando o ar com bastante força e depois soltando o ar pela boca bem pausadamente. Uma outra atividade realizada foi um relaxamento que consistiu na sugestão da coordenadora Márcia para que as participantes fechassem os olhos e como estava um dia muito quente, imaginassem uma brisa e uma chuva prateada bastante refrescante... O relaxamento foi conduzido de modo a envolver todas as participantes.

Exercício de coordenação motora -1) Bater os pés alternadamente em seqüência grupal, primeiro só com os pés, depois adicionando as palmas, no final bater com força os dois pés no chão e as mãos soltando os movimentos.

Depois levantar e alongando o corpo, levantando os braços - flexão lateral de tronco para os dois lados alonga e solta os braços.

Flexionando os joelhos, balancinho dos braços para frente para trás primeiro simples, depois ir acalmando, tomando leve o movimento, coordenando com a respiração, o tronco para frente, com a cabeça também, mexendo a cabeça, para um lado pro outro (alguns comentários sobre os barulhinhos que fazem na coluna cervical "parece uma moenda"! risos)

Alinhando o corpo, solta os pés.

2) Siga o mestre: cada uma "inventa" um movimento e as outras imitam.

EE: Olha essa ginástica tá valendo!!

Cantam noi meio: Balançando os braços: "balança caixão..."

Conceição! Conceição!

Termina essa brincadeira, soltando as articulações puxa o ar pelo nariz e solta pela boca, balançando cada pé.

3) Bla-Blação:

Colocando a emoção, inventar um a lingua inexistente, "conversar" de dois a dois.

Andando pelo espaço - encontrar uma pessoa e começar a bla-blação.

-Falando mal de alguém.

-Contando uma historia bem triste (eles entraram bem, depois risos) 
-Contando uma historia bem alegre(muitos risos)

-Falando uma coisa bem séria (TS: agora o que eu falo serio agora?).

(entraram bem também)

\section{Encenaram em Bla-blação.}

Todo mundo num show e cada dupla vai cantar em bla-blação um ritmo que quer primeiro combinem, depois apresentam.

$\left.1^{\circ}\right)$ OMS e TS, cantam e dançam em samba, pagode.

$2^{\circ}$ )TSS. e EE, um e um em samba canção e todos batem palmas no final.

$\left.3^{\circ}\right)$ MAA e MLF, cantam e dançam em ritmo animado.

$4^{\circ}$ ) IC e GS cantam uma valsa, IC canta muito bem.

$5^{\circ}$ ) MCS e a colaboradora CC, Trem das Onze em bla-blação.

EE se anima e pedem para cantar uma musica inteirinha.

"O malandro sabe morrer, foi morar lá na cidade..."

Fazem uma roda e todos acompanham com palmas e dançam e cantam juntos.

TS samba no meio da roda.

Coordenadora: Alguém quer cantar alguma musica?

TS sugeriu que todas cantassem Trem das onze - todos cantam e dançam.

IC cantou "Mamãezinha".

Depois sentamos no banco:

Coordenadora: Eu queria saber o que vocês lembram, quando vocês cantam assim, essas musicas antigas.

EE: Lembrei da minha mãe, porque eu tenho mãe né! (chorando)

TS: Eu lembro de uma amiga minha, ela tinha dois meninos gêmeos, ela cantava bem. parecia radio ele cantava para as menininhas dela. Ela perdeu o marido, perdeu o genro, perdeu o filho, ela sofreu.

Coordenadora: Vocês acham que mudou muito de lá pra cá?

Todas concordam.

Coordenadora: $O$ que mudou?

TS : Dá saudades daquele tempo, parece que era melhor.

EE: Dá muita saudade, de quando a gente era moça.

IC: Eu lembro da minha mãe ! Ai que saudade!

Coordenadora: $O$ que vocês tem mais saudades?

EE: Eu cantava muito em espanhol, meu pai era espanhol! Agora já esqueci.

MCS: Essa musica trem das onze que vocês cantavam me faz lembrar de uma coisa, que me dá uma paixão, meu marido cantava e tocava violão, era a coisa mais linda, em Altinópolis todo 
mundo falcva que não tinha uma pessoa que cantava e tocava violão que nem ele, porque ele aprendeu desde criança.

E ele cantova, porque nós não combinava, ele fazia serenata, ele tocava a noite inteira com os amigos ai de madrugada ele passava e tocava na minha janela, mas era o amigo dele que ele tocar para mim essa musica, um amigo dele que era cego, e pedia vamos fazer uma serenata para sua esposa, porque ela adorava essa musica e você não cantam apara ela. Então eles pensavam em casa e tocavam, então eles cantavam aquela musica e eu chorava tanto, eu escutava aquela musica $e$ chorava tanto de paixão quando ouvia aquela musica não sai da minha cabeça, nunca vai sair.

IC: Já fizeram uma serenata para mim, eu joguei um pinico de mijo - acho que era hora! De madrugada.

(todos falam juntos)

Contam historias de tempo de moça, da fazenda da distância do banheiro da casa, que era no mato, do medo que tinham que chegar no mato por isso todo mundo usava pinico.

Falaram que se usava palha de milho para se limpar, lembraram de urtign e muitos risos.

MCS: Eu tava contando que eu tenho paixão por essa música porque eu ficava triste porque ele não ficava nunca em casa, para fazer serenata.

Se nós fosse um casal que se dava bem que gosta um do outro, quando ele tocava eu ficava feliz, eu lembrava ia na janela, mas ele não fazia pra mim porque ele queria, era porque o amigo pedia. Se fosse diferente! Eu não lembrava, só abraçava e chorava no travesseiro.

Coordenadora: Vamos encenar essa historia MCS?

- As pessoas se organizam, um grupo são o conjunto de serenata.

- Eu sou o travesseiro, você conversa comigo.

- TS é o marido.

- MCS vai tentar fazer como você fazia e como você podia fazer diferente, falar o que você nunca falou.

O grupo pega alguns objetos para acompanhar a serenata e paus de vassoura.

Começa a encenação.

O grupo da serenata canta Conceição deitada encostada no "travesseiro".

MCS: "Vem meu amor, volta comigo vem dormir comigo (para o marido), volta pra dentro, não vai mais fazer serenata."

TS (o marido): Fala: "Se apaixona, oi meu amor!"

MCS: "Oi meu amor por quer você só faz serenata para mim e não entra para dentro?"

TS (o marido): "Eu tô fazendo serenata pra você, porque eu te senti muito triste."

TS (o marido): "O que você tem para me dizer?"

MCS: "Você sempre sai, meu amor Marido: Mas hoje meu amor eu tô aqui pra conversar com você, você tem muita coisa pra me dizer, não tem?"

MCS: "Você nunca entra pra dentro do meu quarto, eu amo muito." 
TS (o marido): "Você sabe que meu ramo é esse, você sabe que eu gosto muito disso aqui, eu prefiro mais ficar para fora tocando. Eu não te enganei você sabe desde o casamento, que eu gosto muito disso aqui, eu não largo nunca. Eu vô morrer disso, sabe que meu ramo é esse aqui.”

Cooordenadora: para MCS falar mais o que você tem vontade de falar...

EE: Ela tá chorando de verdade!.

TS (o marido): "Chora minha Preta chora! Eu sei que mexi muito no seu machucado."

Conceição: chorando.

Coordenadora: Por que você acha que ele não te amava?

Sem resposta

Coordenadora: Ele dizia que te amava?

MCS: Mas ele nunca me disse que me amava.

Cooordenadora: Você adorava ele te amova ou não.

MCS: Não ele não me amava

Cooordenadora: E por que será que ele fazia serenata para você?

MCS: Por que os amigos mandavam

Cooordenadora: Quantos anos vocês viveram juntos.

MCS: Uns 30anos!

Cooordenadora: E ele não amava você? Será? Como um homem pode viver 30 anos e não amar?

TS (Marido): "Por dentro de mim eu amo, eu não digo prá ninguém, mas por dentro eu amo! Você pode ter toda certeza que o meu amor por você é grande. Você diz: ele não me ama, ele não me ama! Mas eu te amo! Não preciso ta dizendo, ta aprendendo aqui, fica em paz mulher que te amo de verdade."

Cooordenadora: $\dot{E}$ que nem todo mundo sabe expressar o amor. Quer dizer mais alguma coisa, diz para ele e para todos os homens do mundo o que eles devem fazer!, alguém tem alguma reclamação a fazer aqui de seus maridos que não falavam, que não expressavam, todos os maridos aqui expressavam o amor?

TS: $O$ meu nunca!

$\mathrm{EE}: A I C$, meu também não, ele era muito antigo!

IC: O meu marido nunca me deu valor!

TSS: O meu nunca falou "ô meu bem, ce ta bem hoje? Me dava um beijo na boca", nunca. Não tinha nada disto, o amor de antes era o mesmo de agora.

Cooordenadora: E como é que vocês sentiam?

IC: Eu me sentia arrasada! Como um trapo sujo jogado no chão!

Cooordenadora: $E$ você falava coisa, reclamova?

IC: Reclamava, mas não adiantava!

TSS: Se reclamava, até que eles faziam só de pirraça.

IC: É que ele fazia mais de pirraça ainda. Ele saia no sábado e só voltova na segunda! 
Tinha rabo de saia! Ai e eu tô vivinha aqui, com as minhas perninhas boas, e ele tá sem uma perna e já vai cortar a outra (Batendo com o pau de vassoura no chão).

Cooordenadora: Agora vamos com esses paus-de-vassoura e vamos bater no chão, vamos bater a raiva prá fora. Tudo que a gente tem vontade de fazer e não fez não precisa falar, sé se quiser.

- Nesse momento todas batem com muita força com os paus no chão, algumas muito alto, alguns paus até quebram!

Algumas falam que não tinham vontade de fazer com o marido, que era bom!

Dai eu completo: Não é só no marido, coisas aconteceram e que você teve que ficar calada coisas que ficavam guardadas

GS: Tem uma coisa que ficou guardada aqui, tem coisa que a gente não esquece, e e eu casei com meu marido que eu não gostava, minha mãe falava que antes dos 20 anos você que escolhe o marido, depois dos 20 ele é que escolhe. Eu gostava de um policial. Eu namorava com esse policial fazia 4 anos, eu era apaixonada por ele, e um dia teve uma festa na Lapa e eu falei que não ia, dai eu fui, eu achava que ele só pensava em mim, ele morava aqui em Ribeirão e eu lá na roça, dai eu fui escondida na festa e ele apareceu com uma loira de cabelo comprido ai minha mãe gostou, ela não queria que eu casasse com ele, ih! Ele chegou com uma loira! Eu fiquei arrasada! Desmoronou! Ai eu casei com meu marido sem amor.

Cooordenadora: Então era a loira que você queria dar uma paulada?

GS: Ele morreu solteiro. Eu pedi para meu primo que conhecia ele saber dele. E ele me disse que ele tinha morrido fazia um mês. O meu marido também tinha morrido, o meu primo falou que ele gostava de mim, disse que no dia do meu casamento ele tava lá escondido, foi a melhor coisa que me esconderam, porque era capaz de eu falar não, eu tinha muita magoa dele. Eu gostava dele, ficava com meu marido e pensava no outro, nóis se amava. Ele chorou muito. Ele pelejava em me encontrar porque eu morei 20 anos em Luis Antônio, e ninguém sabia onde eu estava, aí meu primo nem pensava em me localizar, eu disse prá ele: "cê podia falar quando ele tava morrendo, cê podia me buscar, dizer que era um parente, ai eu ia!"

Meu marido tinha ciúmes, se eu fosse prô lado de Jardinópolis, nossa senhora, meu marido se acabava.

Ai eu tava conversando com meu tio e ele dizia que meu filho podia ser dele, meu tio disse prá ele, ninguém mandou você ser galinha, sem vergonha, ai eu vingava ele, depois que ele morreu eu tenho $d \dot{o}$.

TSS: Quando nós se casamo, nós era unido, era carne e unha, a gente se namorava desde criança, depois que a gente se mudou para cá tudo mudou.

Ele chegava em casa estúpido, ele ia me tratova daquela maneira (ele entrou na prefeitura para trabalhar) é que ele nunca chegou assim de me abraçar me beijar, de jeito nenhum, o beijinho dele era só "naqueles momentos" Ele fazia que nem galinha, o galo saia empurrando prá lá.

Eu soube, não, eu vi, ele arrumou até namorada, cê não viu que ele falou? Ele falou que ele me largava eu ó, com a barriga desse tamanho e ia namorar a moça, ai um amigo meu falou, não põe as 
coisas na cabeça não, mas você tá pra ganhar nenê, eu vi seu marido andando abraçado, e levava a moça até a casa dela. Eu não acreditova porque eu não tinha visto mas aqui eu vi.

Ele saia de madrugada de casa, de bicicleta coma a danada no cano. Ele saia 20 prá cinco de casa prá picar o cartão, ali no SAAE! É tão perto" É prá encontrar com ela, ele deve levar ela até hoje (hoje nóis dorme separado ele saia arrumadinho, fazia a barbinha todo dia).

Faz mais de dez anos que nós não dorme junto, Depois ele entrou no bar! Começou beber, e vinha bebão, bem tonto, me tratova mal, eu dizia prá ele ir dormir no quartinho do meio porque lá na sua cama pode feder bebida, feder suor pode feder o que quiser.

Dai ele começou a ir no recanto, eu sabia que tinha o recanto, um salão.

Um dia eu fui coma as minhas amigas, chamei minha amiga criei coragem, meus filhos já tavam casados, cheguei lá os dois de papo, eu queria pegar era dançando, mas o danado não tava dançando, ele mudou de cor! Ele não sabia nem sair do lugar ai eu sentei com as minhas amigas, $e$ ele veio conversar: "ai você veio aqui?" "eu vim também tenho perna que nem você!".

Você podia ter me dito, se você tivesse falado eu tinha te chamado!"

"Tinha me chamado"? "Nóis num, nóis num somo casado! É ó, a coisinha dele sumiu de lá!

Ele me chamou para dançar ai, eu não quis, disse que vim aqui só conhecer, com as minhas amigas, elas me chamaram. Dai nóis começamos a brigar mesmo.

Ai fui perdendo o amor, começando a questionar, ai eu chamei minha nora, eu peguei ele no pulo, ai chamei ele. Mas falei, falei e disse sua roupa tá na mala, cê que pode ir embora! Ai ele começou a chorar!

Mas ele não foi, nós tamo junto, eu faço as coisa com amor e carinho, porque eu gosto de fazer as coisa pra outro comê com amor e carinho, porque aquilo faz bem para pessoa, porque eu vou chegar no fogão e vou fazer mal feita? Eu não! Deus ta vendo! Por isso, Deus me ajuda eu me dá essa força para mim, eu brinco, eu danço, eu caçôo, eu sô feliz, tô sempre rindo.

É tem dia que a gente engole alguma coisa mas a gente levanta a cabeça e segue em frente!

$\mathrm{EE}$ : Comigo foi diferente meu marido sempre foi bom para mim, eu é que fui sem vergonha! Não assim de trair, não! Eu sempre fui uma mulher muito cobiçada, mas eu nunca sai com ninguém. Mas olha, eu trabalhava na fábrica e o gerente gostava de mim, meu Deus! Eu fiz de tudo prá aquele homem não fazer nada comigo. Ele não fez nada comigo, mas olha, em tudo lugar que eu vou sempre tem homem que gosta de mim, até lá em Bertioga, na excursão, lá na praia tinha homem que dava em cima de mim, ó mas esse pecado, eu não vou dar para meu marido.

Ele já foi, tá lá no céu, que Deus dê um lugar bem bom prá ele, eu era muito fiel para ele, mas ói eu era muito cobiçada, todos os homens gostovam de ficar comigo, me tirava pra dançar, me convidava prá sai, mas eu nunca sai.

TSS: A gente foi muito paquerada, só que no tempo da gente não dova pra fazer isso!

EE: Não dava mesmo! Eu tinha muito respeito com meu pai, imagine eu fazer uma coisa dessa, eu ia deixar meu pai muito triste, meu pai não gostava que os filhos separava do marido, eu tive uma irmã separada do marido e ele ficou muito triste. Mas separá por quê? Meu marido me adorava, nós nunca fiquemo separado, nem na hora da morte. 
TSS: E nóis num dorme junto de jeito nenhum!

Cooordenadora: Qual o significado do envelhecer prá vocês?

EE: Não sei o que vou falar... Nesses dias atrás eu fui para são Paulo, fui na casa da minha irmã, eu fiquei meia esquisita, mas sei o que eu tinha, eu comecei a pensar assim, eu acho que vou morrer logo, até meu filho pegou e falou assim, "fica ai que eu vou buscar a senhora no Domingo", "meu filho não vêm porque eu não tô legal, não sei o que eu tenho E., eu não tô legal, não sei explicar para você", eu tova com isso na cabeça, eu tava muito triste.

TSS: Deve ser depressão! A senhora tava deprimida!

EE: Meu Deus ! agora eu tô bem, tô ótima, eu vi aquele dia empurrada, agora eu tô bem, eu não tova legal, não tava mesmo, hoje eu vim com uma vontade! Eu tô bem mesmo, tô animada não sinto mais nada! $O$ que será que aconteceu comigo?

Cooordenadora: Será que não tem a ver com a visita que você fez prá sua irmã em São Paulo, você disse que ela tava magrinha acabada..

EE: Eu falei mesmo, minha irmã tá muito magrinha mas ela tá feliz! Eu falei prá ela, "você tá feliz, você tem tudo, você fez uma reforma na casa, a sua casa tá uma mansão! Que coisa linda! Eu sei que não foi você que fez, foi sua filha, mas ela é muito rica."

Eu sei, que eu fui tirar a roupa na frente dela, ela ficou me olhando assim, ai eu perguntei "Maria, que foi? "Ela falou, nada, mas ela me viu que eu tava cheinha, mesmo meus peito é duro, não é caido. eu tô sem soutien, ela tem uma pelanca assim caida, não tem peito mais. Eu falei, nossa, Maria você tá muito magra, mesmo e ela tem 72 anos e eu vou fazer 75. Será que foi por isso que eu fiquei triste?

TS: Deve ter sido isso! Vê ela daquele jeito cê ficou com aquilo na cabeça A gente fica mesmo!

EE: É porque eu já perdi uma irmã com doença ruim, eu pensei assim, "será que eu vou perder a M.?" A gente fica meia triste né!

Maria Angélica, minha menina disse assim: "Mãe a tia tá muito magra"! A mão dela ficou preta, até esses ossinhos ficou levantado de tão magra! Eu falei: "M. olha tua mão!"

Ela disse: "Eu sô magra, eu como, mas eu sou magra!

Até seu marido tá vivo! O meu tá morto!

Eu sinto muita a falta dele, o nosso casamento foi lindo!"

Cooordenadora: (retomando): Qual o significado do envelhecer prá vocês?

IC: Num pensar na morte!

TSS: Não pensar na velhice!

IC: Não pensar que vai morrer amanhã!

Coordenadora: Por que não pode pensar?

IC: Se pensar é que a morte vem mais depressa! Eu não penso na doença, eu tenho muito problema. Eu penso que eu quero viver.

TS: Não pode desanimar que ela chega mesmo!.

IC: Velhinha a gente tem que ficar velha, 67 anos!68! a gente vai ficar velha, mas a gente não sabe quando a gente vai embora. 
Coordenadora: Como é velhice para você? Essa velhice que você está falando?

IC: Eu acho que eu vou ser muito irritante se essa idade já sou irritante, imagina mais velha?

Coordenadora: Por quê ficar irritante?

IC: Eu acho que todas as pessoas que fica de mais idade, ficam cheias de manias.

Coordenadora: Você vê isso nos outros?

IC: $\operatorname{Sim}$

Coordenadora: $E$ em você?

IC: Eu acho que vou ser assim porque sou assim desde agora, imagina quando ficar mais velha. Minha vó morreu quando tinha 99 anos! Ela era irritada. Ela era espanholinha, ela falcva eu não entendia.

TS: Depois que a gente vai pegando certas idade, acaba uma dança, acaba um olhar, acaba um namoro, a gente gosta de olhar! A gente fica mais velho, isso acaba, não tem mais aquela influencia mais de paquerar, de dançar.

Coodenadora: Por quê?

TS: É porque a gente já ficou enfraquecida, já envelheceu.

Coordenadora: Em que sentido você envelheceu?

TS: A gente envelheceu em muitos sentidos na cabeça, naquele sentido. $O$ corpo já não é aquele corpinho mais ajeitadinho, as carne já secou um pouco, enruga, você pode se arrumar mas nunca mais volta aquela coisa.

EE: É não volta! Nunca mais volta aquela menina linda que eu era! Eu era muito linda!

TS: Eu gosto de andar bem arrumadinha, hoje eu me sinto mais realizada nas coisa, eu sinto, que nem agora eu tô velha, mas não me sinto velha!

Coordenadora: Por quê você está velha?

TS: Porque tem que ir ficando mesmo, o corpo vai ficando, os anos vão passando...

O mês que nem tem mais um ano prá mim assim no meu pensamento eu não tô me sentido velha, agora no meu corpo...

TS: Na minha mente, eu não me sinto velha. Sô paquerada, paquero! Bom né?!.

Coordenadora: $E$ é bom sentir paquerada?

TS: Mas é uma beleza! (se sentir paquerada) Sexta-feira, (levantando-se) no baile, um senhor de Jardinópolis falava assim para mim "mas você tem um corpinho, hein? Quantos anos você tem, que mal lhe pergunte? Eu falei 59! Eu tava dançando, e o homem "você é elegante, tem um corpo bonito" você é bem conservada, eu falava "é". Lá tem uns velhos prá frente!

GS: TS quantos anos você tem?

TS: 61 anos!

Coordenadora: E para você MCS, qual o significado do envelhecer?

MCS: Sei lá! Eu não me acho velha agora, não me acho!

Coordenadora: Mas você pensa no envelhecimento, na velhice?

MCS: Eu penso! 
Coordenadora: $O$ que você pensa?

MCS: Eu tenho medo de ficar doente, de precisar de alguém para tomar conta de mim, é só isso que eu penso.

TS: Eu não penso na velhice!(E levanta e vai do outro lado imitando um casal de velhos, iniciando uma história que vivenciou.)

Coordenadora: $O$ que foi $T S$, mostra prá nós como é?

TS: Eu fui chamada na Água-Minas fazer uma consulta lá, tava esperando chamar e tinha um casal de velhos, eu fiquei olhando e pensando: ele era gordo, ela pegada no braço dele...Eles vindo devagar. Eu juro por Deus me deu uma tristeza, me deu uma angústial Ai meu Deus, como a gente vai embolando a vida da gente! Ai meu Deus, essa manqueira na perna dele, gordo, já velho, aquilo parece que foi puxando as coisas de mim para fora! Olha até onde a gente chega!

Cheguei em casa me deu vontade de chorar fiquei tão caladinha assim ...

TSS: Meu filho ligou prá mim.

EE: Qual o JP.?l

TSS: É ele liga direto, ele tem um ciúme danado de mim. Ele disse: "ô mãe, ô mãezona." "Falei mãezona mesmo, tô de mala e cuia," "mas onde a senhora ta indo?" "Mas a senhora não pára hein!". - "É isso ai mãe, bola prá frente vai curtir mesmo! Não fica prá trás não!!

TS: A minha filha sempre fala: "Não fica quieta não, vai passear, vai divertir a vida!

Coordenadora para MLF: $O$ que significa envelhecer prá você?

MLF: De primeiro, eu fazia aniversário, eu falava que tava ficando velha, que eu ia morrer logo! Agora não, quando eu faço aniversário eu fico contente. Eu sou de mês de maio. De primeiro eu tinha medo.

GS: Ela fez aniversario e não falou para ninguém.

Coordenadora: $E$ agora você tem medo?

MLF: Agora não, eu divirto.

Coordenadora: Você não pensa nisso?

MLF: Eu pensava, agora eu não penso mais, se vou ficar velha. Eu gosto de me aprontar, de passear.

MCS: Eu encontrei a MLF num dia ela tova tão chique tão bem arrumada, de uns tempos pra cá ela melhorou, né? É outra pessoa.

Coordenadora: $E$ você $O M S$ ?

OMS: Ai, ai, ai, não sei o que vou falar...Quando eu ficar velha, eu tenho medo de sofrer por que a gente fica doente e precisa de alguém olhando a gente, só isso.

Coordenadora: $O$ que você pensa da vida que tá vivendo agora?

OMS: Eu sô feliz!

Coordenadora: $O$ que você pensa pro futuro?

OMS: Eu quero ter um carro pra passear.

Coordenadora para MRV: O que você pensa da velhice? 
MRV: Eu penso que quando a gente vai ficando mais velha, a gente fica doente. Eu não fico assim na idéia, por que envelhecer a gente vai mesmo, não adianta ficar pensando.

Coordenadora: $E$ a GS, só falta ela.

GS: Eu aceito, mas eu não me acho velha! Assim normal, primeiro a gente é novinha, depois fica adolescente, moça, depois casa, fica mulher, tem os filhos e vai envelhecendo então a gente vai aceitando, assim é normal.

GS: Eu tava conversando com a minha irmã, ela é mais nova que eu 2 anos, mas ela se entregou assim dentro de casa, não sai, só sai de carro, se ela chega lá em casa e já quer ir embora. Ela foi, outro dia em casa, trouxe um presente prá $F$. "toma ai $F$., trouxe um presentinho", e nem senta, "tô com pressa." A filha dela falou: "pode sentar que eu não vou embora agora não, enquanto a gente não formar um café que a tia GS faz não vou agora não", aí eu falo: "ai N., vamos na ginástica, vamos dançar"! Um dia eu tava indo no show de chorinho, a TS tava lá, a professora ia ensinar a gente a dançar, eu ia indo embora e nem vi um homem que tava lá, olhando mexeu comigo: "a senhora tá me devendo uma dança"! Eu não tava com vontade de dançar, se eu quisesse eu saia pisando no pé dele, ai eu falei: "eu vou pagar um professor para me ensinar a dançar e nos vamos dançar a noite toda, só com você e lê ficou olhando eu disse: "tá bom, eu vou cobrar!"

Eu queria aprender a dançar, mas naquele dia eu não queria dançar, o professor da biodança, dança tanto, ele vai no baile dança, precisa de ver a gente se encontrou ele me beijou, me abraçou, a minha cunhada assim curiosa, "o que ele è seu?". "meu professor" (ele é baixinho, o nome dele é V.) (Disse para as outras que perguntaram. TS: então vou procurar o $V$.)

MCS: (Levanta com as mãos no peito): Deixa eu me abrir, deixa eu falar: Eu nunca pude falar, me abrir, nunca tive uma pessoa que eu pudesse falar, essa parte que você me mandou falar, eu tinha vergonha de falar as coisas, nunca me senti segura prá falar as coisas, agora não, eu me senti libertada prá falar o que falei hoje prá vocês, você meu travesseiro, aquele travesseiro que eu chorava, né, eu sei que eu deitei no teu ombro, assim prá mim foi tão bom isso aí, assim me desabafar, foi tão bom isso ai, eu me desabafei né, foi tão bom isso ai, fazia tanto tempo que tava guardando isso, né, pra mim foi uma beleza de presente, para mim vocês tão de parabéns.

Coordenadora: Você também está de parabéns! como foi para a IC?

IC: Eu gostei de tudo, um pouquinho de cada coisa.

Coordenadora: De cantar?

IC: Não, eu cantei feio!

Todas: imagina!!!

IC: As últimas palavras que eu cantei, eu cantei chorando.

Coordenadora (encerrando): Como foi para vocês?

MLF: Gostei demais - tudo é muito bom.

TS: Eu gostei dos jogos, de cantar, de sê o marido.

OMS: Para mim foi o show que nois fez.

TS: Depois todo mundo vai ver essas coisas? 
Coordenadora: Não essas fitas ficam quardadas, reservadas só se vocês quiserem uma fita. Eu vou preservar o nome e a imagem de vocês. Por isso que eu peço para assinar esse termo de consentimento.

MRV: Eu fui relaxando, gostei de tudo.

GS: Gostei de tudo, da cena da MCS também, parece que ele sortôu o que tava guardado.

TSS: Para mim foi bom porque a gente desabafou, contou a vida da gente. Eu pude falar da minha relação com meu marido, de como a gente se entendeu, agora a gente é que nem irmão.

EE: Eu gostei de tudo, gostei daquela ginástica que a gente fez aqui, achei bacana, às vezes a gente não tem nem essa ginástica com a professora de ginástica.

Coordenadora: $\dot{E}$ importante ter um espaço de se colocar. $O$ que dá prá sentir é que vocês entram mesmo, se colocam. Em que momento da vida isso acontece? Que espaço vocês tem para se colocar?

TSS: É só numa parte assim que nóis tamo aqui, porque eu nunca tive, nem em tempo de criança a gente teve uma brincadeira assim.

Coordenadora: $O$ que eu queria falar é que é muito importante o que vocês trazem para gente, não só para vocês, prá gente também, eu a CC, a ACS, cada vez que vocês trazem uma coisa nova repercute alguma coisa em nós.

\section{NONO ENCONTRO}

\section{Data:11/02/2003 Horário: 14:30 as 17:30 horas}

\section{Coordenadora: MPC Colaboradoras: CC e ACS.}

Participaram deste grupo: TS, MLF, NMS, OMS, MCS e EB.

Primeiramente executamos um exercício de coordenação motora, que consistia em bater pés em seqüência grupal, depois adicionando palmas. Foi feito um breve relaxamento, que consistiu em todos os participantes fecharem os olhos e tentarem imaginar uma chuva de prata bastante refrescante caindo sobre a cabeça de cada uma delas, uma vez que estava muito quente, sentir o cheiro da chuva caindo, imaginar que cai uma chuva prateada, que vai limpando os pensamentos, as preocupações, depois sentir escorrendo por todo o corpo, mencionando cada parte desde a cabeça até os pés, então, um dos objetivos foi promover uma sensação mais refrescante através do relaxamento, depois, que a nuvem da chuva se vai e aparece um sol dourado, que envolve como uma toalha dourada cada parte do corpo.

Levantando de olhos fechados, pegando na mão da pessoa ao lado, fecha a roda, transferindo o peso do corpo para os dedos dos pés, erguendo os calcanhares, puxando o ar levantar os braços, e soltar o ar, levantando, ficando centrada novamente, abrindo os olhos, abre bem a roda, o máximo (nesse momento chega $\mathrm{E}$ ) 
Abre bem o corpo, braços e pernas, tentando ocupar o máximo de espaço, como se estivesse numa redoma, depois um casulo, que vai aos poucos apertando e vamos encolhendo o corpo bastante, até o máximo, depois ao contar até 3 , a gente vai estourar o casulo, pulando e soltando um grito. (muitos risos). Este exercício foi repetido três vezes.

Soltando o corpo, mexendo todas as articulações, desordenadamente (samba do crioulo doido), até cansar, pode ir parando, respirando fundo, soltando o ar devagar, fechando os olhos, concentrando no corpo, avaliando como se sente no momento, onde está a mente, se há pensando, como está os sentimentos no coração, no estômago, as emoções. Como esta a vontade.

Recapitulando sobre o que foi pedido há um tempo atrás sobre o desejo no futuro, . Considerando que já havia sido feito em um grupo anterior os desejos que elas gostariam de ter realizado no passado e o que gostariam de realizar no presente, faltando apenas falar dos desejos futuros, todas expressam o que desejam:.

TS: Meu desejo é de ter muitas coisas bonitas, boas na vida, muitas roupas bonitas, muitos calçados bonitos, prá passear também, um pouco de dinheiro no bolso.

TSS: Pede pro bem!

TS: $O$ bem tá tão rapado! O bem não tem prá dar prá mim. Eu tinha muita vontade de ser alguém na vida, meu desejo é esse, mas espero que antes de chegar o final dos tempos eu seja alguém na vida.

Coordenadora: Mas você não é alguém na vida?

TS: Ah! Mas alguém de mais categoria, de mais alta sociedade é assim que eu tinha um desejo né.

Coordenadora: É você acha que ia se sentir bem assim?

TS: Eu acho que ia me sentir um bocadinho bem.

Coordenadora: E você NMS?

NMS: Eu queria ter uma casa para mim morar, só minha, sem aborrecimento sem nada, com aquelas luzes de fachada, para pode levar minhas colegas; e saúde , né?

Coordenadora: $E$ você $M C S$ ?

MCS: Eu queria ter um carro na minha vida, nossa! Eu sonho para ter um carro na minha porta! Minha menina tem carta, só falta um carro.

TS: Pode falar outro sonhinho que eu queria?

Coordenadora: Pode.

TS: Esse sonho é de lá longe... Eu queria ser uma daquelas princesas, daquelas do Gugu, do Daniel ou do Netinho, sinto paixão por isso, acho demais da conta. Acho que eu ia realizar um sonho tão gostoso, que eu ia flutuar no ar eu não ia nem andar no chão, esse dia que eu fosse princesa, de um daqueles colegas gostosos lá, isso é que eu tenho vontade. Esse era um dos meus sonhos também. Não tinha importância que eu tô veia! Mas eu queria ser uma princesa dessas! Ai que legal! 


\section{Coordenadora: $E$ você $E B$ ?}

EB: Eu, primeiramente a minha saude! Total! sem nenhum problema. Eu queria terminar a minha casa, meu sonho é terminar minha casa todinha, por piso no meu quintal e ver meus filhos bem felizes com as mulher deles. Eu queria também ter um dia de rainha, dai é de rainha que eu queria ser, dia de rainha...

TS: Princesa!

EB: Mas sou véia é rainha.

Coordenadora: Porque você fala que é velha?

EB: Passou de 50, é rainha.

TS: Ainda dá uma princesa, é gostoso viu!

OMS: $O$ meu é ter um carro e uma casa, uma casa para mim e para minha familia e um carro.

MLF: Meu desejo é igual da NMS, ter uma casa para eu morar sozinha, ter meu som e ter um pouco de dinheiro pelo menos para ajudar meu próximo que tem mais necessidade, esse era meu desejo.

TS: A primeira que você ia ajudar era eu!

MLF: Eu não, cê não precisa!

Coordenadora: Vamos fazer uma encenação então desse desejo, como se fôssemos realizar esses desejos?

Inicialmente encenação pela TS.

Coordenadora: Distribui papéis que as participantes escolheram

TS com bastante dinheiro vai ao shopping fazer compras, algumas são as vendedoras das lojas, outras são do programa do Netinho e Daniel. Coordenadora acompanha TS como secretaria particular, no shopping, primeiro sugerindo à TS, umas instruções de postura.

Enredo: TS precisa de roupas novas, pois foi convidada para ser princesa, no programa do Netinho.

TS - "Hoje vai ser meu dia de princesa, que roupa devo usar?"

Coordenadora(como secretária): "Eu acho que tem que combinar tudo!"

Entram na loja (tem várias sandálias das próprias participantes no banco, objetos pessoais, óculos, etc.)

Vendedoras - "Nós temos lindos vestidos e objetos."

Coordenadora (como secretária) Fica pegando varias roupas e sapatos.

TS Fica experimentando vestidos, roupas, bolsas, TS desfila, escolhe roupa.

Atende celular:

TS - "Oi bem eu tô aqui no shopping fazendo umas compras por que é meu dia de princesa!"

Servem champagne na loja, escolhem vários vestidos, óculos, jóias, brincos de diamante, pulseiras de platina com esmeraldas. Vão embora em seu carro blindado nos bastidores do Netinho.

OMS (como Netinho) apresenta o programa, chama a princesa. 
TS - "Hoje é meu dia de princesa, tô muito feliz, foi um sonho que eu tive na vida, eu queria que você me levasse para jantar, junto com os príncipes (muitos risos, todas participam ativamente) aparece 0 "Martinho da Vila".

Todas cantam a musica do Martinho da Vila: "Canta, canta minha gente que vida vai melhorar..." A princesa declara - "Eu estou feliz em ser princesa do Netinho, tô flutuando no ar."

Agora é a vez da EB.

Coordenadora: Como você pretende realizar seu desejo de terminar sua casa, o que é que falta?

EB: Dinheiro.

Coordenadora: Vamos Começar pelo programa do Netinho.

ACS: Ela pode ganhar do Netinho, os materiais de construção.

Distribuem os papéis.

Coordenadora (como Netinho)- Apresenta o programa e chama a EB.

EB agradece, mas fala que quer de verdade.

No programa recebe o bônus para os materiais de construção.

EB vai na loja de materiais de construção. TS faz o papel de Leonardo, que acompanha EB e começa a cantar: "entre tapas e beijos..." e a dançar. OMS, MLF, MCS vendem os materiais... ACS chega com a revista mostrando para decorar a casa. Termina com palmas.

Encenação do desejo de NMS.

NMS repete o desejo.

Coordenadora: $O$ que precisa para conseguir isso?

NMS: Dinheiro!

Coordenadora: Como você conseguiria esse dinheiro?

EB -Ganhando na loteria, na Sena.

Resolvem encenar.

NMS escolhe as pessoas da familia, das três irmãs o papel mais chato foi para Coordenadora:, TS e MCS fazem as outras duas irmãs.

Começa a cena na hora do almoço.

Coordenadora (como L.) dá uma bronca em NMS porque a irmã chegou tarde.

NMS fica brava e diz, mostrando o bilhete da loteria que ganhou na loteria um prêmio para comprar a casa própria. Todas ficam contentes, TS (irmã mais nova) diz quer vai com a NMS, Coordenadora (como L) pergunta se ela não vai ajudar, MCS (irmã do meio) também diz querer ir junto. NMS entra com bastante vigor no papel, dá bronca e discute com a irmã L. Sai de casa e vai comprar o imóvel, as outras irmãs vão junto! EB é a dona do imóvel e negocia com NMS. L aparece e quer dar palpite. NMS acaba levando a as duas irmãs para morar junto, $L$ acaba se aproximando de NMS, diz que não quer morar sozinha. NMS diz que ela pode construir do lado. Ela negocia com L que quer morar junto e acaba doando seu quarto até a construção da casa nova de L. 
NMS coloca que na verdade não quer morar completamente só, mas que quer ter uma casa sozinha, próxima das irmãs

NMS: Na minha casa a gente, briga, briga, ai passa 15 minutos depois fica tudo calmo.

\section{Encenação do desejo de MLF}

Coordenadora pergunta como são as pessoas da familia, e pede para MLF escolher entre as participantes.

MLF escolhe as pessoas da familia e diz que umas que enchem o saco!

EB: Conta quem mais te enche o saco em casa?

MLF: Os netos, Deus me livre.

EB: Quem é o Neto que enche o saco?

MLF distribuindo dos papéis:

-Você é o meu neto mais chato que tem na minha casa (para EB)

-Vocé é minha filha (para coordenadora).

EB: Como é a filha?

MLF:Minha filha é assim...

EB: Não peida e não cheira?

MLF: Meio mimada, enjoada, chatinha, meia querendo mandar na gente e eu não aceito sabe? E os netos são chatinhos

Coordenadora (como filha): "Ô filhinho, troca de canal para mãe" (filho bonzinho). "Ô filho (filho chato) vai pegar um copo de água para mãe." (MLF diz que esse é o neto mais ruim).

OMS é o neto mais bonzinho, EB é o neto mais chato.

MLF chega, pega a filha e os netos discutindo e acusa a filha de não ter educado os filhos. Discutindo com os netos, diz que precisa bater nos filhos o "neto ruim" diz que lugar de velha é no asilo, ela (MLF) fica brava, quer agredi-lo fisicamente, a filha interfere dizendo que ela tava "gagá mesmo, que tava velha". O neto ruim instiga a Vó, a filha diz que ela tá velha e que a filha fica apontando o dedo para ela, diz "você não começa a dar mal conselho não". MLF tenta agredir várias vezes o neto ruim, que diz "Velha é trapo!" o outro neto fala: "Eu não acho a senhora trapo."

MLF: "Vocês querem ir dormir?"

Neto nuim e filha: "Nois não, a gente quer assistir o filme." MLF diz que paga a luz e que não é para assistir TV que vai botar todos para fora, para pagarem o aluguel a filha diz que assim vão mora embaixo da ponte.

Batem palmas na porta da casa, entra o moço da loteria e anuncia que MLF ganhou na loteria. Todos fazem festa, abraçam a vó por interesse e pedem dinheiro, MLF diz que vai pensar no caso.

O Neto ruim pede uma moto, a vó diz que eles são muito malcriados e que vai comprar uma casa só pra si ... e que vai pensar se vai ajudar.

MLF vai procurar uma casa. O neto bom tenta ajudar, chama a mãe, e vão na "rua" ver casas. Aparece um ladrão (TS) e rouba o cheque de MLF, todos correm atrás dela, e a MLF recupera o cheque (muitos risos). Ela compra a casa e se muda, dá para a MCS um dinheiro para ela comprar um carro. 
Para a filha ela não dá nada, elas brigam. Para o neto bom ela dá um pouco de dinheiro, a filha fala que ela ia precisar dela um dia quando ficasse doente. Ela diz que não, ela fala que as colegas ajudariam..

\section{Encerramento}

Coordenadora: Cada uma fala como foi realizar o desejo e o que significa o envelhecer.

EB:O que eu gostei foi essa ultima peça, foi mais agradóvel (risos)

Coordenadora: $E$ a encenação do seu desejo?

EB: Parecia de verdade, foi bom.

Coordenadora: Pareceu?

EB: Parecia de verdade, gostei.

Coordenadora: Qual significado do envelhecer para você?

EB: É horrivel, é horrivel ser velha.

Coordenadora: Você se sente velha?

EB: Não me sinto velha, só sei que tô ficando velha.

Coordenadora: E o que é horrivel?

EB: Não sei , vão ficando ruim né?! Trapo. Eu sei que agüentova subir uma escada e não agüento subir, vai acabando a resistência, vai acabando as forças, eu por mim não queria ficar velha nunca, estacionava agora.

EB: Eu não aceito envelhecer. Mas ai a gente vê os artistas ficando veio na televisão vai se conformando.

TS: A gente se conforma bastante.

EB: Você vê um Tarcisio da vida véinho, nossa! Quando você começa a sentir que tá envelhecendo é horrivel, comigo é assim! Não sei se todo mundo é assim! Eu acho horrivel!

TS: É a gente não fica reparando assim quando...Tem que levar as coisas no trupicão é o que eu contei um dia naquela UBS da Água-Minas, aquela véio gordo, andando, coitado, machucadinho, me deu uma vontade de chorar, cheguei em casa mais triste, aquilo lá foi uma pena prá mim, me doeu, ai meu Deus onde a gente vai parar.

Coordenadora: Você pensou no significado da sua velhice?

TS: Justamente eu olhei aquilo passou para mim. Foi aonde me deu vontade de chorar me deu vontade de chorar, ói ele tá assim e como eu vou ficar?

Coordenadora: E como você acha que vai ficar?

TS: Eu vou ficar uma veia bem impertinente, ishi eu vou ficar uma veia bem ranzinza!

EB: Eu tenho certeza que eu vou ser uma veia bem legal, bem pra frente!

Coordenadora: Quando você acha que vai ficar velha?

EB: Lá pelos 80, eu vou sentir.

Coordenadora: $E$ você TS?

TS: Eu também, la pelos 80 é que eu vou sentir, agora eu não posso sentir não quero!

EB: No final dos 80 já vou me sentir. 
TS: Lá pela casa dos 80. porque tem uns de 60 e 70 que tá bem mais esperto, tem muita gente de 70 anos que ta bem esperta!

EB: Mas também em compensação têm uns de 20 que eu não dou um dedinho.

MCS: 'Tem uns velhos de 83 anos lá no baile dança com gente, dança com a gente que nem um trem, mas dança! Vai tanto homem como mulher mas dança, a gente fica de boca aberta de ver eles dançar!

Coordenadora: E como é que foi para você hoje TS?

TS: Maravilhoso!

Coordenadora: $O$ que você gostou?

TS: A história da Princesa! Tenho tanta vontade de ser uma princesa na vida mesmo? Ishi! Me realizei com aqueles vestidos, $\hat{o}$ soinho que eu tinha viu! Realizei eles. Eu tenho uma vontade de ser uma pessoa assim importante, ser assim uma pessoa viajada, uma pessoa retirada na vida, passeadeira, nossa! Eu tinha vontade de ser uma pessoa grandinha mesmo.

EB: Quem sabe na outra geração cê foi!

TS: Quem sabe! Eu tinha vontade de participar daqueles programas no meio daqueles artistas, eu queria tá ali no meio, parece um sonho que eu tinha de tar ali no placo com aqueles artistas, lá cantando.

EB: Ah! Porque você já tá apresentando, você já é artista já TS! Nos já somo artista! Nós apresentamos nossa dança lá no shopping! Nos já somo artista porque cê tá ai reclamando? Apresentamos na casa do Bosque. Um dia que nos formos apresentar vamos convidar a professora prá ir.

TS: Eu já passei na televisão, você tova aquela vez que a gente passou lá no teatro $D$. Pedro? A repórter me chamou lá dentro! Nossa ela me entrevistou, tinha dança dos idosos, e a mulher lá em cima do palco. Ela me perguntando, e eu dançando, "você gosta de dançar TS"? Nossa! Eu adoro dançar, queria ser uma artista, eu queria ter ido com o moço dançar....Não é que passou na televisão! Quando eu encontrava com os outros na rua, falavam assim: "Eu te vi sabe aonde? Na televisão", ai meu Deus!

EB: Pronto, você já teve seu dia de artista!

TS: Televisão sim, a menina falando comigo e eu rindo...

EB: A primeira vez que a gente apresentou, apareceu na televisão chegou em casa todo mundo disse que tinha visto a gente. Quando a gente acabava de dançar aquele povo vinha pegar a mão da gente. A gente subiu na vida!

TS: Pediram pra gente apresentar mais uma vez.

Coordenadora: Quem falta falar?

OMS: Eu.

Coordenadora: Fala OMS.

OMS: Gostei das brincadeiras, me senti bem no teatro que nois fez, gostei das brincadeiras, da moto que eu ganhei! Do Daniel, da princesa, do Netinho, de ser filha, de ser irmão. A gente vai envelhecer e os filhos vai olhar os pais os irmãos. 
Coordenadora: E quem não tem filhos?

OMS: Os irmãos cuidam, só isso.

Coordenadora: Como você sente os anos passando?

OMS: Ah! Os anos que eu passei eu achei chato! Por que minhas irmãs pegam muito no meu pé, não deixam eu fazer o que eu quero, a N. não deixa, a L. não deixa, a C. não deixa. Três força prá cima de mim.

NMS: Sabe o que ela fez uma vez? Ela veio aqui na ginástica, ela foi lá na D., aquela que tem o filho maconheiro. Ela foi lá e deixou passar uns 3 dias, ela faz tudo quietinha. Ai ela disse depois, na semana, sabe porque eu demorei domingo? Eu fui na D., buscar um vidro de remédio. Sabe que tem na D.? O filho dela é maconheiro e uns cara juntaram para matar ele. O filho dela fez um muro bem alto, com um portaozão bem alto, porque a $D$. tem medo de sair prá fora.

EB: Ela foi embora para o Paraná

NMS: Mas se a gente soubesse não deixava ela ir lá, eu sei, mas ce já pensou se ela vai lá e os cara aparece prá matar ofilho dela?

E a gente nem sabia onde a D. morava! Tá certo isso? E' que ela gosta de se socar na casa de qualquer um, essa vira lata! (risos)

Coordenadora: E prá você MCS? Como foi hoje prá você?

MCS: Foi maravilhoso! Foi gostoso! (EB quase chorou de rir!) Eu tova falando para ela! A gente podia apresentar isso no dia da peça! Foi muito muito bom, muito alegre, foi bom demais.

Coordenadora: E qual o significado de envelhecer para você?

MCS: Eu não gosto de ficar velha. Por isso que eu alevantô, já arrumada, pintada, prá não parecer que eu sô muito velha. Eu não gosto de ficar velha, mas eu não me preparo para não ficar velha.

EB: Eu não passo nenhum creme para não enrugar!

MCS: Eu vou lá no espelho, troco de roupa, passo creme, batom, perfume, protetor. A filha pergunta: "Mãe você vai na cidade?"Por quê? "Porque cê tá tão arrumada." É que eu vou no Mercado. "Ah! a mãe é diferente de nós " Eu sou mesmo!

MCS: Eu me sinto bem assim. Tem gente que não, tem muitas amigas minha que pensa assim: "eu sô velha prá que fazer isso?" Ah! Eu respondo ishil Eu faço mesmo! Eu sou velha, mas gosto de me arrumar, no tempo de moça eu não podia, meu marido não deixava.

Coordenadora: E como você se sentiu hoje? (para MLF)

MLF: Eu gostei muito, me senti como se fosse de verdade gostaria que chagasse nesse ponto de comprar minha casa.

Coordenadora: E qual o significado do envelhecer prá você?

MLF: Outra vez! Nem sei o que eu falo! E se eu repetir?

Coordenadora: Pode dizer o que quiser!

MLF: Ficar veinha, gagá, não dá não! Tem que ficar ó, tinindo!!

Coordenadora: Porque não dá não?

MLF: Ah! Não a gente fica assim jogada prá lá! Por que é veia! não! 
Coordenadora: Você se sente assim, jogada prá lá?

MLF: Na minha casa eu me sinto! Mas quando eu tô aqui com meus amigos, não. Já na minha casa, eles nem dão bola prá mim.

Coordenadora: Você acha importante darem bola para você na sua casa?

MLF: Acho que sim, porque eu sô igual a criança, se a pessoa se dá bem comigo, tudo bem, ishi, eu fico muito contente, mas se a pessoa não tá nem ai, eu fico prá lá.

Coordenadora: $O$ que é ficar prá lá?

MLF: Ah fico prá lá vou prum canto.

Coordenadora: E isso te aborrece?

MLF: Sim ... se a pessoa me agrada, eu fico contente, porque, eu era uma criança muito quieta, eu morei com gente muito ruim, não conversava com ninguém. Depois que eu me casei, fui criando familia, fui soltando mais um pouquinho. Agora é melhor, depois que eu comecei a vir na ginástica, melhorei. No começo eu tinha vergonha, ficava num canto, não falcva com ninguém.

MCS: Eu comecei a conversar com ela, toda vez, eu conversei com a C. para por ela junto para ela poder melhorar, e ela foi melhorando, ela era quieta não falava nada.

MLF: Agora eu brinco, corro, faço bagunça.

Coordenadora: $E$ você $N M F$ ?

NMS: Hoje foi legal. Gostei da casa que eu comprei, gostei de ser vendedora também, para mim foi tudo bom. Eu não penso nada na velhice não tô nem ai prá velhice, eu só quero passear.

Coordenadora: Por que não pensa?

NMS: Ah! Eu não tenho tempo de pensar, a hora que chegar chegou! Só olho de vez em quando, quando chega o fim do ano. Passou mais um ano! Será que o ano que vem vou estar aqui! $A$ hora que chegar, chegou! Vai passando! Nóis já viveu bastante. Só que nóis fala, nos não vai chegar na idade que o meu avô chegou, morreu com quase 100 anos, nunca ficou doente. Meu pai e minha mãe morreram novo. Eu tinha um tio que morreu com 24 anos. Tudo do coração. Eu acho que vou viver pouco por isso não penso na velhice.

\section{Termina a Sessão}

\section{DÉCIMO ENCONTRO}

\section{Data : $18 / 02 / 2003$ Horário: $14: 30$ às $16: 30$}

\section{Coordenadoras: $\mathrm{CC}$ e $\mathrm{ACS}$}

Neste encontro não estive presente, mas descrevo aqui um relato breve do encontro.

Participaram deste grupo as seguintes pessoas: IC, NM, TSS, TS, MLF, AS (participou do grupo pela primeira vez), OMS, $N M S$, GS, MRV, MCS e EB.

Foram feitos alguns exercícios de aquecimento e algumas cenas do cotidiano de algumas participantes. 
A questão sobre o desejo futuro foi retomada com as participantes que não haviam comparecido na semana anterior- TSS, GS, NM, IC, MRV e AS.

$O$ desejo de IC para o futuro é que ela possa ter bastante saúde e conseguir um emprego, mas com os problemas de saúde que ela tem hoje é muito dificil de conseguir uma patroa que a contrate. Diante deste depoimento fizemos a encenação em que IC iria procurar emprego na casa de MLF que estava bastante rica pois ganhou na loteria e havia comprado uma casa só para ela (esta situação foi retomada da semana anterior em que o sonho de MLF era que acontecesse isto.) MLF seria uma patroa malvada e não iria aceitar IC com os problemas de saúde que ela tem.

Houve a participação das demais integrantes do grupo, dando sugestões para a forma como IC deveria fazer e também algumas dicas para MLF representar a patroa "maldosa". Muitas delas, lembraram de situações já vividas em relação à atitudes de patroas que já tiveram. MLF teve uma participação significativa trazendo elementos importantes de serem discutidos como: a autoridade das patroas, o limite de cada uma em aceitar o que é determinado pela patroa e a questão do respeito que cada uma delas julga merecer.

Em um outro momento, GS representou a patroa "boazinha" que não exigia além do que IC poderia oferecer e também a liberava para que pudesse ir ao médico uma vez por mês. Foi bastante interessante trabalhar com estas questões. Pois também foi observado o lado do empregado em abusar quando a patroa é muito boa. Isto tudo foi discutido.

TSS comentou sobre sua enorme vontade de continuar estudando no futuro e também de aprender a dirigir um carro e tirar carta. Como MCS também havia comentado sobre este desejo na semana anterior foi montada uma cena em que as duas desejariam tirar carta. Foi combinado com as demais participantes o papel que cada uma iria fazer nesta cena. Tiveram os seguintes personagens: o dono de uma auto-escola, os professores para ensinar a dirigir, o delegado, para fazer a prova e o dono de uma concessionária para elas (MCS e TSS) comprar um carro após tirarem carta.

No meio desta encenação, foi possivel perceber das demais participantes que não participavam desta cena, principalmente MLF e EB, uma certa inquietação com alguns cochichos entre elas. Elas claramente mostraram insatisfação pelo fato do grupo haver decidido em não apresentar uma peça no dia do encerramento das aprimorandas. EB comentou que havia vindo para o grupo exclusivamente para ensaiar a apresentação, se ela soubesse que não teria apresentação, não viria. MLF disse que queria muito apresentar e que se caso não tivesse apresentação ela não participaria mais do grupo expressivo- teatro.

Diante disso, ao conversar com grupo para que EB e MLF pudessem expor seus sentimentos, elas falaram para o grupo sobre o desejo de apresentar. Então, combinamos que 
poderia ser feita uma apresentação relacionada com o cotidiano delas, algo que gostam de fazer ou alguma situação que gostariam de representar para um público. Elas decidiram apresentar uma situação em que estariam combinando de irem para um baile de carnaval e que a MLF seria a cabeleleira e a maquiadora das demais participantes que iria para o baile.

Diante desta decisão foi possível perceber nitidamente uma mudança no rosto de cada uma delas que ficaram bastante eufóricas com o fato de acontecer a apresentação. A motivação foi muito visível e elas mesmas se articularam e deram idéias de roupa e cenário. Diante disso, fizemos apenas dois ensaios e ficou decidido que a apresentação iria acontecer.

Ao finalizar o grupo fizemos o grito de guerra "alegria de viver" e MLF comentou que se não fosse ter apresentação ela realmente não participaria mais, ela considera que fazer parte deste grupo tem sido muito importante para ela e experimentar a sensação de artista por um dia "seria tudo de bom". Desta forma, o grupo encerrou-se.

No dia 20/02/2003 aconteceu a apresentação Pública no teatro do SESC de Ribeirão Preto/SP.

\section{DÉCIMO-PRIMEIRO ENCONTRO}

\section{Data: $25 / 02 / 2003$ Horário: 14:00 às $16: 00$ horas}

Coordenadora: MPC Colaboradoras: CC e ACS.

Participantes: $M L F, O M S, N M S, M R V$ e GS

Encontro após a apresentação do teatro. Registrar o descontentamento de MLF com a apresentação pelo fato de ter cortado alguns pedaços da peça ensaiada anteriormente e de não ter dado tempo de fazer tudo que estava planejado.

Houve primeiramente uma avaliação sobre essa apresentação. Formamos um circulo de mãos dadas abrindo bem o círculo. Abrir e fechar as mãos levantando os braços, respirando coordenadamente com os exercícios. Respiração alternada: Puxando o ar, soltar gritando Rá, flexionando o tronco para frente. Balancinho de braços com joelhos flexionados. Rotação de tronco com braços pendentes. Siga o mestre de movimentos movimentos variados, bater pés, flexão lateral, rotação de quadril, flexão de joelho para um lado e o outro apontando as mãos sobre o joelho flexionado, rotação da cabeça, braços à frente cruzando, relaxando tudo com chute à frente. Exercicios duplos aleatórios exercícios de espelho.

Exercícios do espelho da verdade, cada uma diz o que está sentindo de si para o espelho. (CC, colaboradora fez o papel de espelho). 
OMS:- Eu tô feia, tô ficando véia com o cabelo meio branquiado já.

Espelho -Tá nõo, tá bonita.

OMS: -Tô ficando gorda, agora.

Espelho -Tá não, tá bonita.

OMS: -Tô com roupa feia?

Espelho: $-A$ roupa tá bonita.

OMS: -Pele feia?

Espelho: -Não tá feia.

OMS: $-E$ o sapato.

Espelho: -Tá bonito.

NMS no espelho: -Ai meu Deus do Céu hoje tô tão cansada. Quanto eu trabalhei!

Espelho -Ah él?

NMS: -Eu vou aprender a bordar Eu e minha amiga .Na quarta feira eu vou participar da festa da minha amiga.

NMS -Tó cansada de ficar em casa, eu vou para Minas.

Espelho - O que tem em Minas?

NMS -Tem muita coisa, eu vou na casa de um, de outro, esquecer um pouco o presente.

Espelho -Por quê o presente tá ruim?

NMS -O presente tá meio chato.

Espelho -Por quê tá meio chato?

NMS -O povo daqui é muito esquisito.

Espelho-O povo daqui, e você tá bem com você?

NMS -Eu tô muito bem comigo. A familia é mais ou menos, minha familia é muito chata, minha irmã me perturba, o cachorro me perturba.

Espelho -Até o cachorro?

NMS -Até o cachorro me perturba.

Espelho -Você não gosta dele?

NMS -Gosto, mas ele é muito chato, tenho um papagaio que é esquisito...Sou eu que preparo tudo. Eu preparo o café, o almoço, com OMS minha irmã.

Espelho -O que você mais gosta de fazer no seu dia-a dia?

NMS -Gosto de limpar a casa, fazer comida.

Espelho $-E$ por que falou que tá muito cansada, chegou aqui e falou que tava muito cansada?

NMS - é porque eu trabalho de pé, cansa demais, às vezes eu demoro horas pra fazer o almoço e isso cansa.

Espelho-Mas você tá muito bem.

NMS- Tá bom, Obrigado.

MRV no espelho: Eu tando aqui, eu tô muito feliz, eu ando mais animada.

Espelho- Que legal, que bom e o que você mais gosta de fazer? 
MRV: Eu gosto de deixar tudo em ordem, eu ligo o rádio e vou trabalhando, escutando as musiquinhas.

Espelho - E como você se sente?

MRV: Eu sinto bem Graças a Deus, principalmente agora que eu internei e emagreci 10KG, embora eu tô ficando mais enrugada, mas eu não tô nem ai com as rugas, mas meu espirito é outra coisa.

Espelho -E por que foi internada?

MRV - Eu tenho pressão alta, diabetes, osteoporose, chagas, disrritimia no coração, ai deu água no pulmão e eu tive que internar ai tiraram litros de água do meu pulmão e fiquei nova.

Espelho - Mas a senhora tá outra, continua assim esse problema vai passar, viva a vida. Teu espirito tá alegre?

MRV - Tá! Meu espirito tá jovinho, tem gente que fica preocupada, cê tá emagrecendo, pensando que eu tô mal, tem roupa que tava guardada há seis anos, agora eu tô usando de novo a roupa não servia faltova um palmo, agora é que eu tô feliz, eu tô fazendo ginástica, caminhando, tô fazendo direitinho maus trabalhos, minhas consultas. Minha vizinha fica admirada, porque minha casa é grande, mas eu limpo todinha. "Ah! cê tem problema no coração", eu não ligo eu não canso de limpar.

Espelho - É ótima sua presença aqui.

MLF no espelho: Tô bem, tô muito bem, mas só que eu tô muito gorda, sabe eu ando demais de tarde sozinha, faço caminhada dura mesmo, chego em casa suando, debaixo do chaveiro fico com o corpo bom mesmo, coloco uma cadeira e deixo cair à água, depois assisto minha novela, que eu gosto demais, nossa que eu tô tão feia, eu tô feia demais eu não desmagreço.

Espelho - Você queria emagrecer?

MLF: Eu quero ficar bonita, eu tenho um sonho, sabe, eu tenho um sonho de um dia encontrar com o Daniel eu amo ele, já pensou se eu tiver gordona na hora que ele chega assim? $\dot{E}$ um sonho mesmo.

Espelho -Quer emagrecer para isso?

MLF -Eu quero ficar bonita, tô muito feia, sabe? Eu quero emagrecer para isso.

Espelho -Eu acho você tão bonita, tão cheia de vida.

MLF -Mas quando eu encontrar com ele eu quero ficar bonitinha.

Espelho -O que você faz para encontrar com ele? Você manda carta para o Gugu? $O$ que você faz?

MLF - Meu sonho, só é eu mandar uma carta, mas só que a coragem não deu.

Espelho-Então tem que criar coragem, se essa é o grande sonho, pega um a cartinha lá, põe na caixa postal do Gugu, manda e espera.

MLF -Vou ficar feliz hein! Que delicia, hein!

Espelho- Então tem que mandar sim, senão não vai ter chance de nada. Que mais tem alguma coisa te incomodando? Te deixando triste?

MLF - Na minha casa ninguém me dá atenção, eu fico triste. 
Espelho -Mas não liga não! A gente vai dar um jeito aqui de deixar você mais alegre.

GS no espelho: - Espelho, espelho meu! Existe pessoa mais bonita do que eu?

Espelho - Não você é a mais bonita de todas.

GS-Eu tô velha, não, eu não me acho velha! Só tô de cabelo branco!

Espelho-E o que têm? Você gosta de cabelo branco?

GS - Gosto (passando as mãos no cabelo), gosto de teatro, gostei de dançar, tô contente aqui.

Espelho - Tem alguma coisa que ta te incomodando?

GS -A única coisa que incomoda é não ter dinheiro.

Espelho - Mas isso incomoda todo mundo

GS -Mas tendo saúde, graças a Deus, mas tô bem, gosto da minha familia. Eu gosto da minha casa, eu sô muito familia, das minhas irmãs.

Espelho-Mas você tá bem?

GS: Só um pouco feia, mas eu não ligo.

Espelho - Mas você não é feia

GS -Eu já emagreci bastante, eu era mais gorda, só o problema de diabetes, mas eu tiro de letra.

\section{Espelho -Perfeito!}

Surge a proposta de encenação da casa da MLF. Os papéis são distribuídos: NMS é a filha da MLF, (MLF diz que não gosta porque ele não dá atenção, acha ela meia falsa), Neto bom da MLF é OMS, Neto ruim da MLF é GS. MRV é a amiga.

Inicia a Cena:

Filha - Oi mãe (passa reto).

MLF - Oi!

Filha - A senhora vai fazê almoço hoje?

MLF - Vou pensar no seu caso, conforme o jeito que me tratar!

Filha - Ih! Mãe a senhora tá sempre reclamando como a senhora reclama, hein!

MLF - Eu ! num sei!

Filha - O que tá acontecendo com você? Por que tá assim?

MLF - Murmurando, Você! Você!(muito triste, chorando)

Filha - Por quê?

MLF - Tô triste com você!

Filha - Mas o que eu tô fazendo para a senhora mãe?

MLF - Quando você precisa de mim, você chega perto de mim e fala, "ô mãe a senhora vai faze a janta? Ô mãe fez a janta pra mim, eu to cansada", mas quando ce empina o nariz assim (mostra a ponta do nariz com o dedo), ce passa perto da sua mãe assim, faz que nem conhece.(filha vai para o quarto). 
MLF- Oi colega.

Amiga - Oi amiga! Como vai (se abraçam e conversam).

MLF - Vamos dar uma volta!

Amiga - Vamos! ( saem de mãos dadas).

Neto bom Chega:- A Bença vó.

$O$ outro Neto ruim entra junto e nem cumprimenta.

O neto bom: - Oia lá, o $\mathrm{Z}$ nem deu bola para a senhora.

MLF - Nós dois num si dá.

Neto Bom - Por que?? "Ah! Ele é malcriado"

MLF - Ele é malcriado ele pensa duas vezes pra responder mal pra vó.(Z sai acenado para ir pra lá e não fala).

Neto bom - Tá vendo só como é que é vó? Ele precisa apanhar vó (vai conversar com o Z).

Neto bom: - Ô $Z$ por quê você faz isso com a vó?

$Z$ : - Pra sacanear!

( $\mathrm{OZ}$ e a filha vão conversar no quarto)

$Z:-A i$ que se dane! Né mãe ,a vó tá esclerosada!

Filha: - Ela disse que não quer saber de você, não. Você precisa ter mais paciência com a vó.

$Z$ - Você não tem paciência com ela.

Filha - Mas ela ta meio esclerosada.

MLF - Esclerosada tá ocê cara! Esses dois são unha e carne (mostra os dois dedos polegares se esfregando), vocês dois são de mesma laia.

$Z$ - Ce passa perto dela e não liga, eu faço a mesma coisa

Filha - mas a casa aqui é da mãe, senão ela manda a gente pra nua.

$Z$-Vamos morar debaixo da ponte então.

Filha - Vamos mora na favela.

$\mathrm{Z}$ - Favela eu não moro.

Filha - Tem favela boa.

Neto Bom - Não da bola pra que os dois fala vó! Esses dois é ruim.

MLF - Esse neto aqui eu gosto! Esse aqui, minha amiga.

Filha - Por que você leva ele com você, vai com ele.

Neto bom - Eu vou morar com a vó, eu vou.

MLF - Esse neto aqui é meu amigo, mas vocês negocia da filha e neto! Ó! Atrás de mim cês vai morar na ponte por que a casa é minha, ceis tem que dá graças a Deus que ceis não paga aluguel, vá pega aluguel procêis vê.

Filha - tem que tacá na cara da gente toda hora que a casa é sua! Vamos embora.

MLF - Tem que tacá na cara mesmo!(fillha e neto saem reclamando)

Filha - Nós vamo dá um jeito na nossa vida!

Neto bom - Xispa da casa! Ó a roupa dóceis, ces não vão levar?

Filha-Nós vai procura casa! 
Neto bom - Eu acho bom mesmo!(Muitos risos, passa um homem no local eles desconcertam)

Todos se encontram na rua

Neto bom - Ces tem que ter respeito da vó.

Z-Puxa saco.

Neto bom - Eu sô mesmo!

(muitos risos)

Cena Ideal - Neste momento é proposta a cena ideal, de como a MLF gostaria que fosse.

Filha se aproxima da mãe.

Ô mãe, vamos na casa daquela sua amiga, como ela chama mesmo?

MLF - M (picando papel como se estivesse cozinhando)

Filha - Vamos bater um papo com ela, parece que a senhora tá triste! Por que a senhora tá triste?

MLF - Ah! Não adianta falar senão cê fica triste também!

Filha - não fico, vamos mãe desabafa comigo!

MLF - Hoje eu não to nem legal pra falar! Ta bom !

Filha-Mãe?!

MLF - Outro dia a gente fala ta?! ( com carinho)

Filha-Mãe que cê tá picando?

MLF - Vou fazer carne com batata.

Filha - Eu gosto tanto, a senhora lembra quando eu era pequena, a senhora fazia?

MLF - Eu alembro!!

Filha - Então deixa eu ajudar a senhora nós tem que morre aqui mesmo!(as duas ficam fazendo a comida, pedacinho de papel, elas simulam bem o fogão)

MLF - Vamos abaixar o fogo e nois vai na casa dela (aparece o $Z$ )

Z: - Aí vó , vou ser um neto bonzinho.

Filha - Ce é ruim!

Z: - Mas eu vou ser bom! Dá um abraço vó, você também melhorar com a sua mãe também (fala para a filha).

Filha-Eu vo desligar o fogo.

MLF - Vamos lá filha.

Filha - Olha a sua amiga mãe ( na padaria elas se abraçam e se cumprimentam)

Neto bom - Ô vó quer que eu ajude você a limpar a casa hoje! Eu gosto tanto da vó

Z-É puxa saco!

Neto bom - Ô vó, ele ta atentando outra vez!

MLF para $Z$ - Some da minha vida. Vai embora!

$Z$ - Ele puxa muito saco, isso não tem saco!

MLF - Ó ce vai procurar casa!,

Filha - Ce não vai na casa da colega dela? Malcriadão, então toma conta da casa! 
MLF- Ce vai procurar casa e vai embora.

Filha - Ainda bem que ele vai fazer 20 anos e vai sumir de lá, vamos passear (os 4 saem, MLF, neto bom, filha e amiga.)

(Vão no jardim -vamos no bosque) termina a cena.

MLF dá uma deciaração do que eu ela gostaria que os familiares fizessem.

Troca de papeis.

NMS é MLF, MLF é a filha.

Filha- Oi mae, tudo bem? Como passou o dia hoje?

MLF - Oi filha! Não to sentindo nada, graças a Deus. tenho que levantar cedo amanhã .Quero descansar bem hoje.

Filha - Ô mãezinha eu te amo (e abraça a mãe).

MLF - Também te amo minha filha!

Filha - Te amo muito.

MLF - Senta aí mãe.

Filha - Mãe a senhora lembra daquelas mulheres que conservava com a senhora, que vinham em casa e convidavam você para viajar, passear, eles são legais né!

MLF - Elas são boas.

Filha - Mas tem uma que tem uma cara assim esquisita.

MLF - É! Mas passa!

Filha - Pois é ne'!

MLF - Ela mudou de bairro?

Filha - Deve ter mudado, porque sumiu.(amiga bate palma)

MLF - Olha quem apareceu! Menina! Tá sumida, entra ai, minha filha tai.

Filha - Oi tudo bem com a senhora, tava falando da senhora agora cadê a sua outra amiga?

Amiga - A outra amiga ta ali mesmo

Amiga 2 - oi amiga, tudo bem eu vim com a minha amiga.

Filha - Mas ce não veio com ela?

Amiga 2 - Eu tava lá no bar (as quatro sentam-se)

Amiga2 - Eu trouxe um bolinho para gente tomar café aqui.

Filha - Ai mãe corta logo pra gente provar! Deve ta gostoso.

Amiga 2-Ta gostoso mesmo, é de coco.

Filha - Ai mãezinha!(fica comendo o bolo e tomando café)

(batem palmas na porta)

Amiga2 - Responde para quem bate palmas,

Amiga 3 - MLF está!?

Amiga 3 - cumprimenta todas.

Amiga2 - Senta ai.

Amiga 3 - Ta tão bonita sua filha! 
MLF - Obrigada!

Amiga 3 - Vocês tão conversando, antes não conversavam.

MLF fala como ela própria - Mas agora vô falar, depois que eu entrei na ginástica, aprendi muita coisa com a psicóloga ela, ensinou muita coisa para a gente, agora chegou as meninas fazendo teatrinho com a gente, agora a gente ta ó (com as mãos só pra cima)

Amiga 3 - Tá bom , tá ótimo! Eu vou entrar também!

MLF - E você filha entra também.

NMS no papel de MLF - Eu ainda to trabalhando bastante não dá.

Amiga 3-E a sua filha?

MLF - Ta por ai, não quer saber de estudar, não quer saber de fazer nada.

Amiga 3 - Mas ela era tão boazinha./

MLF (NMS) - Mas ela tá sapeca!

Amiga 3-A é?

MLF - Agora ta sapeca demais não obedece, não obedece a vó dele, só quer saber de ficar na rua.

Filha - Que é isso mãe

MLF - $\dot{E}$ isso!

Amiga 3 -E os netos?

MLF - Do mesmo jeito que a senhora conhece, não mudou nada, ainda bem que eu to aqui.

Filha - Vamos dar uma volta (e todas saem)

Volta a cena, só a MLF e a filha.

Filha - Mãe, ce fica falando mal da gente, de meus filhos! O que é que ta incomodando a senhora?

MLF - (NMS) você não vê que os seus filhos são malcriados, não vê aquele outro que pronta, esse menino não respeita ninguém.

Filha-Qual , que apronta?

MLF - O R. Ele não respeita ninguem, nem a mãe ele respeita.

Filha - Mas ele é bonzinho.

MLF - é bonzinho mas tem certas coisas que não dá.

Filha - Meus filho é tudo bonzinho.

MLF - Mas pra toda mãe os filhos são bonzinhos, eles pode ser um demônio que as mãe acha bonzinho, eu era assim quando ocêis era pequeno.

Filha - Eu sei quem era o mais bonzinho, o J é bom.

MLF - $O J$ não fez nada! $O J$ pisava na linha, o outro era dificil.

Filha -É mais a partir de hoje eu vo começar a puxar orelhinha dele! Só que ele vai me avançar.

MLF - Chama os homem! Não tem telefone aí.

Filha - Uso o telefone da vizinha.

MLF - É melhor assim, ele vem vê.

Filha - Pois é ! ele é grande né, agora que ele fez 15 anos! 
Neto bom (J) - Também a vó fica só implicando com ele!Dando bronca nos colega dele, quando eles vêm em casa!

MLF - Tá certo eles são mal elemento.

Neto bom - Mas são colega dele.

MLF - A tua mãe ta certa.

Neto bom - Mas a vó não quer que raia.

MLF - Que raia! Pode deixar!

Filha - Pode ralhar sim! Só calma mais um pouquinho, mais avó!

Coordenadora: É legal quando a gente faz o papel invertido! O que você achou MLF?

MLF: É legal.

Coordenadora: Por que muitas vezes você vem falar aqui no espelho, que você é feliz, que aqui você gosta de vir. E, às vezes você chega na sua casa e você não gosta

MLF: Dá vontade de ir pro outro lado....

Coordenadora: Dá vontade de ir pro outro lado, você precisa também entender os dois lados, tanto de filha como de mãe. E o que a gente tá fazendo enquanto a filha e enquanto a mãe! $O$ que foi pra você NMS?.

NMS: O que você esperava dela hoje, MLF?

MLF: É o que eu esperava dela hoje, só que não é assim, eu tinha vontade que fosse, só que não é assim.

NMS: Mais hoje ta assim.

MRV: Quando fica nervosa ces todos conversa?

MLF: Se a gente fala nos filho dela, ela não gosta ela não aceita.

NMS: E o marido dela, é uma porcaria, ele não mora mais com a filha dela, só que quebrou as pernas e tá lá. Ah! Não por que não deixou entrar?

MLF: Uai mas como eu dizia, a filha é teimosa. Eu falei que não, ela pegou direto e levou ele pracasa.

NMS: E ele não tem familia?

MLF: Tem mas eles não moram aqui, eles moram em Minas.

\section{DÉCIMO-SEGUNDO ENCONTRO}

Data: 11/03/03 Horário: 14:00 às $16: 00$ horas

\section{Coordenadora: MPC Colaboradoras: CC e ACS.}

Participantes: GS, JPS (participou pela primeira vez do grupo), NM, MCS, OMS, MLF, IC

Comentários iniciais -

IC - Eu gosto mais de frio do que calor! No frio você pões um blusa, uma calça comprida, uma meia e resolve, no calor você toma, água, água, água, toma banho 
(trovoadas - IC diz ter medo)

Tirei o sapato. Outras também tiraram. Fizemos um círculo de mãos dadas. Exercícios de respiração, levantando os braços, inspirando, abaixando os braços espirando, flexão de tronco para trás, levantando os braços soltando um ahhh! Repetindo três vezes. Depois solta a cabeça e flexiona o tronco para frente, flexão e extensão alternada de joelho com os olhos abertos, levantando o tronco, soltando as mãos, levantando os braços, fazendo balancinho com os joelhos e braços para frente e para trás. Dando as mãos de novo, soltando os pés na frente alternandamente, balançando os pés, depois chutando(IC fala que seu joelho está doendo), mexe os ombros, erguendo e soltando, $r$ otação de quadril, para um sentido depois para o outro, relaxamento dos braços, pendentes com rotação de tronco e cabeça.

- Exercicio da bola de energia (Tai chi chuan)

verificando se todos estão com os joelhos semi flexionados e explicando por que é bom estarmos com os joelhos flexionados assim quando em pé a questão da distribuição do peso, exercício de molejinho dos joelhos.

IC: Eu não trepo mais em banco, em cima da geladeira tá tudo sujo, de vez em quando eu peço pro veio lá e ele limpa.

Coordenadora - (conduzindo o exercício): Imaginar uma bola cheia de energia, pequena nas duas mãos, depois ir sentindo essa bola crescer, ir mexendo com ela como se ela tivesse vida, imaginar que cor ela tem, o peso dela, circundando sua superfice e sentindo ela crescer. A bola é elástica, cresce e diminui, fecha os olhos, leva a bola para um lado, depois para o outro, para cima e para baixo, sente o cheiro dela, se ela tiver. Deixa ela ficar pequena e "guarda" ela dentro da barriga, apóia as mãos na barriga, respirando.

Exercício de enraizar no chão, tirando os sapatos, puxando o ar, "agarrar o chão" com os artelhos, contraindo os esfincteres, fecha as mãos e se contrai toda, solta o ar, os dedos dos pés, das mãos, relaxa os esfincteres três vezes as duas formas.

Solta os pés para frente e os braços, abrindo bem o olho e a boca e fazer careta, soltando sons, mexendo todo o corpo, pode pular ou bater os pés no chão, soltando os braços para frente, gritando Rou!Rou!

Coordenadora: Esses exercícios são energizantes.

Brincadeira "Imitar um homem primitivo" Fazendo a dança da chuva (índio selvagem). Soltando sons guturais the-he-há-há-hu-hu-hô-hô, encontrando um par, trocar "tapinhas" pelo corpo do outro, como se fosse um cumprimento, depois andando batendo os pés no chão (todos se cansam, e sentam. Foram dois 2 minutos de intensa atividade) (Trovoadas IC tampa os ouvidos, diz ter medo).

Coordenadora: Tão cansadas? 
Vamos sentir a parte do corpo que ta latejando ou formigando! Vamos procurar soltar bem, colocar os braços atrás e esticar as pernas `a frente. Relaxando- Imaginar que tem uma pena branca entrando pela sola de cada pé, essas penas sobem por cada parte do corpo e fazem uma massagem suave relaxante. A peninha entra também em todos os órgãos (alguns se mexem, se reorganizam pois a posição é cansativa -4 minutos)Voltam.

Coordenadora: Como vocês estão?

OMS: senti sua falta na semana passada.

Coordenadora: $O$ que você sentiu falta?

OMS: Das brincadeiras ...

Coordenadora: Qual brincadeira você gosta?

OMS: Diversas, essas brincadeiras pro projeto do teatro fica melhor.

Coordenadora para NM: Como tá prá você esse trabalho?

NM: Tô bem, a gente sai, aprende muita coisa né, distrai, ta ótimo!

Coordenadora: Ea IC como está?

IC: Médio, cheguei aqui com os músculos apertados (aperta as mãos), queria torcer alguém.

Coordenadora: Não é eu que você pretende torcer?

ICP: Não, de jeito nenhum.

NM: Quem ela tova com vontade de torcer ficou pra trás, ficou pra lá.

IC (acenando com a mão indicando lá fora): Prá lá! Aqui tá ótimo a gente solta, a gente tira um pouco de coisa da cabeça, aquelas coisas ruim! (NM começa a contar de um certo dia que o marido da IC respondeu grosseiramente para ela, quando NM passou em frente de sua casa, imitou o jeito que ele falou)

Coordenadora: Esse é o principio do nosso trabalho.

(IC ouvindo NM, completou o diálogo começa a conversar com NM.)

IC: Ele fica o dia inteiro daquele jeito!

Coordenadora: Como é que ele fica?

NM: Ele tava sentado na frente do portão, o portão aberto e a mangueira ligada e ele não fazendo nada! Eu falei para ele: "senhor O. a Mangueira tá ligada (imitando o marido da IC) "Deixa correr".

IC: O dia inteiro naquele jeito

GS: Por causa do problema dele a situação dele não é boa!" Né IC. A situação dele não é boa?!

IC: Não é não! Mas ele procurou, vai! Quem procura acha! Já levei ele em tudo o que é hospital de Ribeirão Preto, fui em Bauru 25 vezes, quer dizer que ele não ficou, quem não fica no hospital até quando o médico dar alta, não restabelece! Ele sempre pedia prá ir embora.

GS: Deu problema no pé também?

IC: $\dot{E}$ da doença!

Coordenadora: E a MLF? 
MLF: Tô gostando demais, não vejo o dia que chega terça feira! Para mim vir! Essas carinhas de anjo (apontando para as colaboradoras) essas coisinhas fofas, né! Vocês trabalham muito bem!(colocando a cabeça no ombro da coordenadora MPC)

Coordeñadora: $E$ a JP como tá sendo prá você?

JP: Tá bom, comecei hoje! Ta bom! Já tô me sentindo mais leve, quem sabe não vou emagrecer?!

Coordenadora: $\dot{E}$ quem sabe?

NM: Realmente emagrece se for todo dia que nem hoje!

Coordenadora: $E$ emagrece se for todo dia de indio!.

NM: Ai meu Deus do Céu! Emagrece!

Coordenadora: Tenho uma proposta aqui. A proposta é a gente encenar a cena da IC, que apareceu aqui hoje, ela chegou a fim de esganar alguém... vamos fazer a cena de sua casa? (para IC) IC (apertando as mãos): -Vamos.

NM: Ce não falou a cena de tua casa que te deixou com raiva.

IC: Depois eu te conto!

Coordenadora: Então conta agora, tenta lembrar uma cena que te deixou brava, pode começar por essa cena que a NM contou.

IC: Hoje eu ele me deixou muito brava, dá vergonha de contar!

JP: Não, nós tá aqui prá escutar, pode contar!

NM: Conta! Que boba!

IC: $\dot{E}$ bobagem!

NM: $O$ que é que ele falou?

IC: Falou não, quis fazer!(risos)

NM: Puxa IC, ele fez desse jeito? Ai meu Deus!

IC: Desse jeito ! O homem tá louco eu vou levar ele prá Santa Teresa.

NM: De dia??

IC: De dia, com o sol quente, assim que eu acabei de levantar!

IC: Claro, uai, eu acabei de levantar, tem serviço para fazer, eu vou ficar com frescura? Isso é frescura!

JP: Coitado!

IC: Não! A gente é mulher, tem que fazer, pelo menos uma vez por semana, tem que fazer as vezes, porque não tá calculando muito, agora vem com essas frescuras? Não!

Vou contar pros meus filhos!

JP: Não conta, isso é só entre você e ele!

IC: Eu conto pro meu filho mais velho!

JP: Coitado! ele pode procurar, se dá deu, se não, não tem problema.

IC: Assim meu filho arruma médico pro pai dele, isso é falta de memónia (apontando para a testa), tem que tomar remédio, tem que parar com essas bobeiras. Quando eu era nova, ele ia 
procurar as mundanas, agora que eu sou véia, to cansada da vida, ele vêm com essas frescuras! Vai pra lá, ô leão.

Coordenadora: E essa vez ai da mangueira que a NM falou?

NM: Eu nunca mexi, nunca falei com ele.

IC: Ninguém conversa com meu marido.

NM: Eu não sei o que me deu! Eu ia indo na rua, eu vi aquilo e pensei em falar com ele: "O a água tá correndo ai", podia ter esquecido a torneira aberta ...Ishi!!

IC: Mas é bom porque eu reclamava, podem achar eu to falando asneira.

Coordenadora: Quem quer fazer o papel da IC? A IC vai fazer o papel dele, você conhece bastante mesmo!

NM: Eu faço meu papel mesmo, eu vou passar e vou reclamar de água.

OMS: Eu vou fazer o papel da IC.

Coordenadora: $E$ você JP vai fazer o papel de quem?

$\mathrm{JP}-\mathrm{Eu}$ faço o papel do filho mais velho.

Coordenadora: $E$ a MLF?

IC: Da amiga ou amigo, O Osvaldo não liga pra mim.

JP: Faz da amiga.

Coordenadora: A OMS que é a IC vai conversar coma amiga (MLF), que vai fazer uma visita, a NM vai passar e falar da mangueira, então a gente pode criar uma cena que vocês lembram de alguma coisa. Então como é que ele $O$. ia falar com uma amiga que vai em casa nesse momento, você pode exagerar até, tentar. Lembrar de como ele é, de como ele fala, tentar soltar de tudo, que você lembrar que ele faz. IC vai tentar falar do jeito que ela, imagina que ele vai falar, eu vou ser a outra amiga.

\section{Começa a Cena}

(as amigas passeando, a NM também está andando na rua e vai passar em frente à casa da Isabel).

IC - Hoje esse $O$ tá um a peste!

O-Resmungando -A Isabel não fez nada, larga a casa, larga a comida!

NM - Passando em frente, ó a água tá correndo, a torneira tá aberta!

O-Deixa que corre!

IC - Ô Osvaldo como você é malcriado, não faz isso! não faz isso não homem! Vou contar tudo pros seus filhos!

(O. Pega o sapato para atacar na IC)

IC - Não ataca esse sapato não.

(Enquanto isso Nair encontra com as amigas, e conta o que aconteceu, as amigas falam que estavam indo lá para casa da IC, as amigas se despedem da NM e chegam na casa de IC, batendo Palmas.)

Amigas 1 e 2-Ô IC!

IC - Vai atendê $O$.

O. - Th! Já vem, essas véias, encher o saco, já! (IC vai atender o portão) 


\section{Amigas - Oi IC? Tudo bem (Amigas se abraçam)}

IC - Vamos entrar!

Amigal - Nós ouvimos dizer que o seu Osvaldo tá Bravo hoje.

Amiga 2 - Será que é bom dia prá fazer visita?

IC - Ih, ele tá uma peste em casa! Já me jogou o chinelo, já me xingou. É o jeito dele, vamos senta.

IC - Senta longe.

Amiga 2-Oi seu $O$.?

IC - Ólha a cara dele! Como ele fica! Hoje ele tá azedo, hoje ele tá uma praga aqui em casa

O. - Cês qué sabê de uma coisa: vão procurá serviço!

IC - Não fale desse jeito com as minhas amigas! ó não repara não ele é assim mesmo ele é muito chato!

O. - Vão procurar serviço.

IC - Depois que cortaram a perna dele ele ficou assim, ele tá essa peste em casa, fica falando desse jeito com as minhas amigas.

O. - Fica essas véia andando pra rua! vá procurar serviço!

Amigas (saindo de perto) - Ih! Eu hein!

IC - Até com os netos ele faz isso.

Amiga 2 - Já pensou em procurar ajuda?

IC - Já, eu procurei, não adianta.

Amiga2 - Já procurou o psicólogo?

IC - Oi ele num que ir, eu já arrumei, mas ele num quer ir

Amiga 2 -É seu O.?

O. - Que que eu vou fazer se fica essa falação nos meus ouvido o dia inteiro? Fica esse nhe-nhe-nhe, Eu não gosto dessa falação no meu ouvido!

Amigal - Mas é bom seu $O$.

IC -É desse jeito que ele faz, não tem mais jeito não.

Amiga 2-O senhor procurou psicólogo, não?

O. - Eu já procurei.

IC - Deixa de falar mentira 0. ! Você não tem vergonha de mentir com essa cara limpa, 0. ?

O. - Não, procurei sim!

Amiga 2 - Mas se ele tá dizendo que procurou, será que não procurou?

IC - É mentira do O.! Ele é mentiroso.

Amiga 2 - Quem é que já procurou? Você já procurou?

IC - Eu já procurei, conversei com ele, ele falou que não ia não! Que não adiantava nem eu arrumar que ele não vai!

Amiga 2 - Ah! Então, olha só!

IC - Deixa ele assim, até a hora que Deus lembrar dele.

Amiga 2 - Acho que nós vamos embora!

(as amigas saindo) 
IC - Ó gente não repara não, que esse homem é uma peste.

Amiga 2 - Tchau seu O.! Melhoras para o senhor.

Amiga 1 - A hora que você tiver sozinha noís volta.

O. - Já vai tarde!

IC - Eu vou internar ele.

Amiga 1 - Ele tá ficando ó (fazendo o gesto de louco).

(amigas vão embora)

IC - Eu porque você falou isso de mim pras minhas amigas? Cê não tem jeito! hein O.?! Vô contar tudo pros nosso filho. Porque cê fica falando mal de mim pras minhas amigas !viu!

O. - Eu falo mesmo.

IC - Então, nem precisa vir mais aqui então deixa a hora seus amigo chegar aqui, deixa, aqueles vagabundo, vem atrás de jogar baralho, deixa eles vir! Deixa eles vim aqui! Não me olha com essa cara não(enquanto isso, Osvaldo esta com a mão em seu membro genital, fazendo o movimento de masturbação).

IC - Ta torcendo? Vai fica sozinho aí! Peste, ruim!

(JP -Ele enrola assim? IC: é verdade -enrola! Ele não falou nada? IC -não.)

(Cena da IC com o Filho)

Filho - Oi mamãe

IC - Eu vim aqui falar pra você, que seu pai tá uma peste em casa!! Sabe o que ele fez hoje? Hoje minhas amigas veio aqui ele xingou todas as minhas amigas.

Filho - Mas que sem educação!

IC - Não queria deixar nem minhas amigas entrar em casa!

Filho - Ele falou isso?

IC - Falou, vai lá fala com ele!

Filho - Eu vou falar com ele!

(Filho Foi Falar Com o pai)

Filho - Ô papai o que ce ta fazendo, que coisa ruim, tratando mal as amiga da mãe?

O. - Vai cuidar da sua mulher, dos seus filhos

Filho - Ô pai ce ta doente!

IC - Vai cuidar da sua casa, não vem me encher meus picuá!

(Coordenadora congela a cena e pergunta para $\mathrm{O}$. como se fosse a consciência dele)

Consciência - $O$. por quê voce faz isso? O que voce ta pensando agora?

O. - Eu não sei.

Consciência - Por que você faz isso? Por que você trata sua mulher assim?

O. - Não enche! (continuando na emoção do O.)Também enche meus picuá?

Consciência - Eu sou tua consciência! Eu tô dentro da tua cabeça. (O. não responde) você não ama sua mulher?

O. - Não!

Consciência -E por quê você ficou com ela todos esses anos? 
O. - Não sei.

Consciência - Como não sabe O.? Pára prá pensar.

O. - essa conversa já tá me enchendo

Consciência - Já saiu muito na vida? Já fez muita coisa? Porque você saia com mulher da vida?

O.(acendendo um cigarro e não respondendo)

Consciência pergunta para IC - Porque você acha ele faz isso?

IC - Ah! Sabe porque ele fica nervoso? Porque não pode ficar saindo muito por causa da perna dele, ele fica nervoso fica respondendo um pouco mal, porque ele não sai.

Consciência - É verdade isso O.? Você sempre foi assim sua vida toda ou você era mais alegre?

O. - Eu era novo, eu trabalhava, ia pros lugar, mas depois que eu perdi minha saúde, eu fiquei atazanado da vida.

Consciência - E com sua mulher, você sempre foi bom?

O. - Ah! Eu era um pouco chato! Eu chegava tarde ela vinha brigar comigo, ela não gostava que eu chegava tarde.

Consciência - Ela tinha razão?

O. - Aí ela saia da minha cama, ia dormir no outro quarto, deixava eu la'sozinho.

Consciência - E você não falava nada com ela no outro dia? Não ia atrás dela?

O. - Tinha vezes que ela saia, ia pra casa da irmã dela, deixava eu sozinho.

Consciência -E o que eu você fazia?

O. - Eu não fazia nada, uma vez eu fui buscar ela, ele num quis vim ficou, com a irmã dela.

Consciência - Você já falou alguma vez que gostava dela de verdade, porque você fazia isso?

Osvaldo - Não.

Consciência - Falou alguma vez por que chegava tarde?

O. - Eu não !Vou falar o quê? Falar que tava com as minhas amigas, com as minhas amantes?

Consciência - Mesmo assim, você procurava ela?

O. - Procurava, mas judiava bastante. Ficava uns 10 dias, uns 20 dias sem procurar ela. Mas eu achava na rua mais gostosa, uai!

Consciência - depois queria que depois ela "fosse" com você?

O. - Mas ela não fazia"” não ela não me dava não!

Consciência -E agora você acha que tá acontecendo isso aí porque? Por que você ficou desse jeito assim?

O. - Boemia, eu saia no domingo e só voltava na segunda.

Consciência - E a sua mulher sempre em casa, cuidando dos filhos,

O. - Ela criou mais os filhos que eu.

Consciência - Então não adianta reclamar , né Osvaldo? Você fez nada pra melhorar essa situação?

O. - (elevando os ombros como sinal de pouco caso), eu não gosto de médico, não gosto de fazer curativo, gosto de ficar sentado, na cadeira fumando meu cigarrinho (Fazendo o gesto de fumar)

IC - Pára de fumar O.!

Consciência - Pensando na vida, né $O$ ? 
IC - Para de fumar O.,não tá vendo tua perna do jeito que tá, O.?! Ó praga de homem!

(O.Tira o sapato e joga na mulher.)

IC - Vai machucar minha perna, praga, praga! Vou contar tudo pro seu filho! tá vendo do jeito que lê é (se dirigindo pro filho)

Filho - To vendo ô papai não pode fazer isso não, papai! Agora ce tá mais veio, tem que fica sossegado, agradando a mamãe, ajudando ela, fazendo um carinho, nela, não pode tratar mal, minha mãe tá velha, cansada, cê ta com a perna inflamada aí né, tá precisando de cuidado! Como você vai fazer para fazer as coisas?

Consciência - Ela que vai cuidar de você!

IC - Eu vou por ele num asilo.

Filho - Não põe ele no asilo não.

IC - Ponho sim!

Filho -Ele vai ficar bonzinho.

IC - Não vai não

Filho -Vai tratar bem da mãe, viu?

IC - Eu conheço ele!

Consciência - Mas você gosta dele?

IC - Não gosta mais dele não!

Filho - Ta vendo! Mas nois gosta! Nos que somo filhos nois gosta, só que não quero que judia da mãe não e cuida da sua saúde, que sua saúde é tudo, ce não tão velho, assim.

(Coordenadora propõe a troca de papeis -IC representada por OMS passa a ser o Sr O., representado por IC, IC passa a ser ela mesma)

Coordenadora: Izabel, agora você vai falar tudo que tem vontade tá? Por quê ele ficou daquele jeito, e o $O$. vai tentar responder. (O. fumando o cigarrinho)

O. - O que você quer muié?

IC - Por que você faz isso comigo O.?

O. - Porque você é muito chata!

IC - Chato é você que fica tacando as coisas em mim, fica me judiando, me maltratando.

O. - Eu pedi para você trazer e não você não trouxe né? A blusa e a bermuda, e você não trouxe.

IC - Eu trouxe tudo, eu passo, arrumo, eu deixo tudo arrumadinho. Você que é muito chato!

O. - Deixa eu fumar o meu cigarro.

IC - Fuma! O medico já falou que você não pode fumar. Porque você fuma?

Consciência - Oh O.! Por que você faz isso com ela. O.?

O. - Eu gosto de fumar e ela não quer que eu fumo.

Consciência - Por que você tratava ela mal 0 .?

O. - Porque eu saia com as outras mulheres e largava ela em casa.

Consciência - E que você acha disso?(Falando para IC)Fala para ele.

IC - Cê acha que tá certa O.?

O. - Num ta né. 
IC - Uma hora eu pego você, vou chamar a ambulância e te levar lá pra Santa Tereza, hein!

O. - Ocê que experimenta, ocê que experimenta!

Consciência - Fala pra ele que marido você gostaria que ele fosse.

IC - Você tem que ser homem bom, ajudar a cuidar da casa, ajudar a cuidar dos filhos, você nunca ajudou.

O. - Você quis filho.

IC - Foi você, não foi eu!

O. - Mas você falava que queria um filho.

IC - Eu nunca falei isso não

O.-Falou! É que você não tá lembrada!

Consciência - E como será que ele é que tem que fazer agora, no presente?

IC - Você tem que mudar! tratar eu bem! Indo nos médico que a gente te leva, faze curativo no pronto socorro, no hospital, não fica enrolando aqueles pano sujo ai no pé.

O.- Então vem faze carinho IC

IC -'Eu vou faze carinho nocê cê xinga, fica bravo,

O. - Não vou ficar mais, não vou fica mais. Vêm minha nega, minha baixinha, vêm minha pequenina.

Eu gosto de você minha baixinha, não vou te judiar mais, cê me perdoa? Só que a minha perna tá doendo hoje!

IC - Perdôo.

O. - Eu não fiz curativo

(JP fala para IC passar a mão nele)

IC - E porque você não foi fazer? Só se eu for junto cê vai!

O. - Se você for eu vou.

IC - é mas eu não tenho tempo pra ir toda hora que você fazer curativo, se eu for assim, quem é que vai cuidar da casa, roupa, almoço?

O.- Quando for faze curativo, eu falo um dia antes pra você adiantar o serviço e ir comigo tá bom assim?

IC - Tá bom

Coordenadora: E uma boa combinação!

O. - Cê me perdoa das coisas que eu fiz, nós vamo vive bem agora tá bom? Eu deix você ir nas suas irmãs, na ginástica, na psicóloga, no teatro.

IC concorda com tudo.

O.- Agora vai buscar um guaraná pra mim no bar

IC - Não tem jeito mesmo.

O.- Vai minha baixinha.

IC - Vai buscar o guaraná.

O. agradece

Encerra a cena 
IC: Minha vida não é flor que se cheire, mesmo.

Coordenadora: $A$ vida de todo mundo é assim, todo mundo tem problema.

IC: Cada um tem um problema, um é mais sério, um é menos sério, cada um tem uma tragédia, eu penso: lá em casa é uma tragédia!

NM: Não é assim, a minha vida é...

IC: Nós no começo de casada, a gente...

NM (interrompendo): Não, que começo?!! Faz 53 anos de casada e é mesma coisa

Coordenadora: O marido é gente boa?

NM: Nossa senhora!

IC: Faz 38 anos...

NM: Nós se ama!" nós se adora, carinho, beijo, sempre foi assim, não acaba.

Coordenadora: Ai que gostoso!

NM: Que nem você falou, que todo mundo tem problema, mas problema com o meu marido não, acha que não existe um casal que nem nois.

IC: Mas eu achei assim, porque quando ele era novo, ele não parava em casa, ele ia pra farra, só voltova na segunda feira, agora que ele ta com as perna ruim e não pode andar, então ele fica nervoso, eu não tenho culpa.

NM: Falam que o casamento com um certo tempo acaba não é?! Não é isso que falam? Que o amor acaba?

Coordenadora: Qual é o ingrediente para o casamento dar certo?

NM: Eu acho que é o respeito, saber respeitar um ao outro. Eu nunca briguei nem falar alto, um com o outro, nem ficar sem conversar, nada.

IC: Ah! Esse pecado eu tenho, se fizer alguma coisa e eu não gostei eu fico o dia inteiro sem conversar, esse pecado eu devo à Deus.

Coordenadora: E o que você faz quando ele fala alguma coisa que você não gosta?

NM: Ele conversa muito pouco, acho que é isso também.

JP: O meu conversava muito, se acontecesse alguma coisa que ele não gostava, ele brigava muito.

NM: Nunca ele me xinga, se xingar perto dele...

IC: $O$ meu fala cada nome que eu não gosto nem de repetir. Quando eu comecei na ginástica, pediram prá eu trazer colchão, sabe o que ele falou? Que eu tava trazendo colchão prá deitar aqui com um homem, aqui na igreja!!!

JP: Isso é porque ele não pode fazer as coisas, fica nervoso, então, ele fala essas coisas, até sem pensar.

IC: Acaba com a gente, pelo amor de Deus! Porque sempre respeitei ele, nunca deixei ele sozinho prá ir prá farra, ele é que nunca me respeitou.

NM: Perdeu o respeito.

JP: Parece que ele acha que se já fez isso com você, cê vai fazer isso com ele também. 
IC: Ele acha que eu vou fazer o mesmo que ele fez? Vou envergonhar meus filhos, minhas noras, meus netos? Eu não, de jeito nenhum!

JP: Na mente deles deve ser assim.

IC: Ele foi danado e acha que eu vou ser danada também.

NM: A gente faz um monte de coisa junto, ontem cedo eu fui com ele na lotérica, fui pagar água, tudo eu vou junto.

IC: Eu tô cansada de chamar ele prá psicóloga., chamei ele, vamos conversas. Mas ele não quer. Uma vez ele fez, só quatrosessão, depois parou.

Coordenadora: Por quê não quis mais ir?

IC: Ele tava indo na Beneficiência fazê a cauterização do coto. Puseram ele lá na psicologia, vinha a perua buscar em casa e tudo, enquanto eu fui junto, ele foi, dai eu não pude mais ir, ele não quis ir mais.

Coordenadora: Então é isso que ele quer, que você fique junto?

IC: Mas eu não posso, quem vi fazer o serviço?

JP: Experimenta ir junto, é duro também prá ele, vai junto com ele, dai ele não pára o tratamento e melhora.

IC: Você acha que toda vez que ele tiver que fazer curativo eu tiver que ir junto, eu vou ter que largar a casa?

JP: Larga a casa!

IC: Se eu deixo sujo, ele reclama.

JP: Mas você tá indo com ele, tá cuidando dele, ele vai entender.

IC: Ele já fala. Ele xinga que eu não limpo a casa, que eu não lavo roupa, que eu não faço isso ou aquilo, principalmente quando não dá aquilo que ele tá querendo.

JP: Então é isso!

Coordenadora: Pode ser isso!

JP: Porque do jeito que ele tá, ele tá precisando daquilo.

Coordenadora: Ele parece ser um homem muito fogoso.

IC: $\dot{E}$. Ele tinha três, quatro mulher no tempo que ele era novo.

JP: É mas às vezes, agora uma só já tá bom.

IC: Eu não sou muito chegada, eu sou uma mulher fria, ele diz que eu sou uma geladeira, fala que eu sô gelada, desde que eu casei, eu avisei ele: ó eu num gosto muito. E ele: eu não ligo! Agora tá vendo!

JP: Tem que rezar bastante prá Deus dar bastante saúde prá você e prá ele. Saúde prá ele, força e saúde prá você agüentar ele.

IC: Se eu ficar de cama quem vai cuidar dele? Eu rezo toda noite prá ele acalmar, prá tirar essa mania que ele tem. Eu rezo muito, mas ele não melhora.

Coordenadora: Parece que ele não tá bem.

IC: Deus que me perdoe (bate na boca), "desgraça pelada" nem gosto de falar esse nome que ele fala, ele chama o dia inteiro. 
JP: $\dot{E}$ isso que atrapalha ele chama, os danado vem mesmo, eles fica em volta procurando, achou, ele entra!

IC: Sabe o que eu faço, eu entro prô meu quarto e rezo o meu terço prá essa "coisa" ir embora.

JP: Na quaresma não pode chamar de jeito nenhum, que ela aparece! Meu cunhado gostava de brigar e falava muito "desgraça pelada" ele falava mesmo, chamava o dia inteiro, até na quaresma. Um dia na quaresma apareceu uma mulher toda mulambenta, no quarto dele com uma vassoura e um saco nas costa, minha cunhada, que tova doente de cama, até assustou, a danada falova assim: "vamo comigo, cê tava me chamando eu vim aqui, vamo comigo, vamo comigo." Ele respondeu que não queria nada. Cê sabe que ele ficou uma semana sem dormir vendo a mulher, ela chegou com as roupa tudo rasgada e queria levar ele, ela falou: "eu vou ficar atrás da porta, a hora que vacê me chamar eu tô aqui." Minha cunhada já morreu, mas ele tá vivo e conta até hoje. Ele ficou até meio atrapalhado.

IC - Eu falei prá ele que qualquer hora, ia aparecer essas coisa feia, ele deu de ombro prá miml ai ele vai cair morto. Ele é católico eu tambèm, minha mãe era muito católica, ensinava todas essas coisas prá gente desde pequena. Na quaresma, minha mãe não gostava que chamava "nome" nenhum. Agora o S. Osvaldo não tá nem aí. Eu falei prá ele, "a hora que aparecer essas coisa feia, perto da cadeira que você tá sentado, você nunca mais vai falar isso. É horrivel né?

JP: Credo!

IC: Ele fala cada nome horrivel. Minha mãe falava que na quaresma não devia comê carne de $2^{\circ}, 4$ e 6 .

Eu tô vindo na orą̧ão de Domingo...

JP: Põe o nome dele na urna da Igreja, todo mundo ora, todo mundo vai orar por ele, já fiz isso de montão, um montão de vezes. Cê vai ver como ele vai melhorá.

IC: Eu vô fazê. Pegar papelzinho e vou por lá

JP: No dia da oração, todo mundo ora junto.

Coordenadora: Vamos falar sobre o envelhecer. Qual o significado de envelhecer para vocês?

IC: Eu não queria ficar velha, não!

JP: É ter muita preocupação, tem que ficá pensando em médico, pensando na vida, pensa em um, pensa em outro, dai vai envelhecendo e pronto!

NM: $O$ que você pensa do envelhecer e da velhice? Eu não pensava na velhice, no teatro é que eu comecei a pensar, porque você perguntava: "O que você pensa da velhice"? O corpo vai enfraquecendo, fraqueza nos órgãos. Eu penso que a velhice é assim.

JP: É os ossos enfraquecem mesmo! Os órgãos vão cansando mesmo!

IC: $\dot{E}$, o cérebro da gente que fica cansado, né?

NM: Eu sei lá! É meio dificil de falar né? Eu não sei a que responder. Não tenho resposta certa.

$\mathrm{JP}$ : A professora sabe. 
Coordenadora: $\dot{E}$ não tem resposta certa!? Eu quero saber dentro de cada uma o que sente a respeito disso. Não o que é envelhecer, mas o significado prá vocês. Se vocês sentem o envelhecer ou não, como é esse sentir?

NM: Que a gente sente envelhecer, sente.

Coordenadora: Como você sente isso?

NM: Eu sinto que eu estou perdendo as forças, a pele vai ficando áspera, enrugando (passando as mãos pelo rosto e perna) É isso! Todo mundo fala: "é velhice!" É velhice.

IC: Quando a gente vai ficando velho... já perdi muita coisa!

NM: Então, a velhice é assim mesmo.

Coordenadora: E por dentro de vocè, $N M$ ?

NM: Eu acho que não sou velha, não!

IC: Nem eu! (risos)

NM: Por dentro eu acho que não estou envelhecendo, não!

Coordenadora: Por dentro você está como?

$\mathrm{Nm}$ : Por dentro... O que é que eu vou contar?

Coordenadora: Você falou que por dentro você não está envelhecendo não, então como você vê isso?

NM: Eu tô vendo que eu não tenho nada!

Coordenadora: $O$ que você sente em relação à vida?

NM: Eu sinto bem.

Coordenadora: Em relação à velhice se você não está envelhecendo, então você está como?

NM: Eu tô nova de espirito, decerto!

Coordenadora: E como está seu espirito?

NM: Meu espirito deve tá muito bom, tá novo, tá muito mais desperto, "Graças a Deus!" O espirito não envelhece, porquê o espirito enfraquece, quando o corpo tá fraco. Então, eu não gosto ficar no corpo, o espirito tem que tá bem. Aí eu acho que meu espírito tá bem, melhor que meu corpo.

IC: Tudo isso que eu passo, toda essa raiva que eu passo, esse desgosto que eu passo, eu não tô muito enrugada (riso).

JP: Mas a velhice tá no corpo, a gente vai enrugando, né?

IC: Vai enrugando...

Coordenadora: Onde está a velhice, no corpo ou no espirito?

JP: Não sei não, acho que tá no corpo e no espirito. Vai chegando o tempo vai o espirito e o corpo vai envelhecendo.

NM (interrompendo a JP): Ele não tem velhice, o espirito. Então é uma coisa só. Só que ele se sente enfraquecido por causa da matéria, porquê a matéria vai se acabando, e ele vai se desequilibrando também, mas velho não! Você acredita em reencarnação?

Coordenadora: Sim. 
NM: Então tail O espirito não tem idade, não tem sexo, não tem nada, o meu quando eu morrê, pode voltá num homem, não tem nada a ver, não tem o que é criança, o que é adulto, é uma coisa só.

JP: Às vezes é isso, uma pessoa que é alejada, retardada, na outra vida ele pode ter sido um espírito orgulhoso, metido, quando ele vortá, vorta no corpo de um alejado, retardado...

NM: É o corpo que tova errado não é o espirito. Isso ai è uma remissão do espirito.

Coordenadora: E para você Jeni. qual o significado do envelhecer? Você se sente velha?

JP: Não me sinto velha, não! Me sinto ainda com um pouquinho de coragem, ainda, gosto de conversar, passear é comigo mesma, eu não sou muito de conversar, mas passear, eu vou em tudo que é passeio, isso eu acho que tô podendo ainda.

NM: Mas, o envelhecimento é o corpo mesmo!

JP: É o corpo que vai cansando, a carne vai cansando, devagar vai ficando mais velha, a gente vai envelhecendo.

$\mathrm{NM}$ : E você tem saudade da vida?

JP: Eu queria ficar na idade que eu tinha quando eu tinha 18 anos, eu era tão bonita! (risos) toda hora que eu olho no espelho, ói que diferença, tô gorda, eu era tão bonita!

NM: Antigamente há uns anos atrás as pessoas morriam mais nova, hoje vive 60,70, 90, há uns anos atrás a pessoa não durava isso!

IC: A minha finada vó, ela morreu com 99 anos!

JP: A minha finada bisavó, morreu com 110 anos!

IC: Ela falava que tinha 99 anos, tava nos documentos da Espanha, ela veio da Espanha prá $c a ́$.

NM: Antigamente não tinha esses posto de saúde, tinha!?

JP: Tinha, sempre teve!

NM: Eu nunca vi, não sei se é porque eu morava na roça!

JP: Sempre teve! agora com esses postos de saúde você vai e não quer morrer.

IC: Só tinha Santa Casa que eu me lembre.

EB: Minha vó nunca foi no médico!

NM: É Santa Casa, né?

IC: E elas morriam novinha!

JP: Minha finada avó morreu com 98 anos!

Coordenadora (para JP): Até que idade você queria viver?

JP: Eu tô com 75, eu sei que é muito, se eu não amolar ninguém eu queria viver até uns 100 anos, mas com saude, eu queria viver bastante.

JP: Não quero amolar ninguém!

IC: Eu queria viver que nem a minha vó.

Coordenadora: Até os 99 anos?

IC: Ah! Até uns 79.

JP: $O S$. O. vai mais hein!? (risos) 
Coordenadora (para OMS): Qual o significado do envelhecer para você?

OMS: Ah! Muito cansaço e preocupação na minha vida, preocupação e cansaço na minha vida, só isso!

JP: Eu quero ficar junto com a minha familia

NM: Isso aí é outra coisa!

IC: Isso é normal!

Coordenadora (para MLF que estava debruçada com o tronco inclinado sobre as pernas): $E$ para você, qual o significado do envelhecer?

JP: Acorda a MLF que ela tá dormindo. Ela dormiu quase toda sessão (risos)

MLF: Ih! Já nem sei (levantando o tronco)

Coordenadora: Você pensa nisso? Como você sente isso dentro de você?

MLF: Antigamente, eu pensava muito, tinha muita preocupação com a filha, com uma coisa, com outra, tudo o que eu ia fazer, a cabeça tava pensando naquilo... tava me sentindo triste, não queria saber de nada, não queria fazer nada, agora que eu comecei a participar, conhecer como é aqui, ai parece que eu faço força prá não ficar muito preocupada, não! O que é que a gente vai fazer, né? Então eu quero mais é fazer, passear...

Coordenadora: $E$ você pensa no envelhecer?

MLF: A gente vai envelhecer não? Mas a gente não pode por muito na cabeça não, ficar assim muito preocupada nessa vida, ficar assim muito preocupada, senão vai mais depressa, mais depressa... (inclinando o corpo para frente)

JP: (concorda com a cabeça) ai vai mais depressa...

IC: Não pode pensar.

MLF: Ai vai mais depressa. Então eu jogo um pouco nas costas. Não penso muito mais, mas não é tudo, eu não fico muito mais preocupada, não.

Coordenadora: Qual o pensamento que vem mais prá você todo dia quando você acorda?

JP: Acho que o meu pensamento é esse todo dia quando vou dormir, e quando acordo. Agradeço a Deus todo dia quando acordo, porque estou viva Graças a Deus vivi essa noite, e vou viver mais um dia.

Coordenadora: $A E B$ quer falar?

EB: Eu não penso em ficar velha, porque eu não vou ficar velha! (risos) Tem dia que eu não penso, que eu quero durar muito e pronto. A única coisa que me apavora é a mortel Tenho horror de morrer. Não quero morrer de jeito nenhum, só isso!

Coordenadora: Alguém pensa nisso?

MLF: Eu penso assim: eu não quero ficar numa cama dando trabalho, precisar dos outros me olhando, me olhando, velando de mim... Oh! e tem uma coisa: se eu ficar bem velhinha, assim, não aguentar mais, melhor eu procurar um asilo prá lá, e vou ficar por lá, sabe?

JP: Isso eu também quero: quando eu ficar bem velhinha não quero ficar amolando ninguém. Quando eu vejo que já tá na hora de vir a idade não quero aborrecer ninguém... 
MLF: Quando chegar a hora chegou! "É pá e pum! Morreu? Morreu", pega enterra, joga no mato...

IC: Jogar no mato não!!

JP: Não pode fazer isso ! Todo mundo é prá enterrar! Eu não quero não ficar amolando. Eu tava conversando com meu filho, ele falava que velho é assim mesmo é só mijaceira, ele tem razão é tanta mijaceira...(risos)

MLF (Conta a história do ex-marido da filha, que foi passar periodo em sua casa junto com ela e os netos, porque quebrou a perna. Com a dificuldade para se mover pedia para os filhos pegarem o que desejava): Os filhos dele, entre eles, falavam: “eu já fui agora é sua vez, porque o pai só chama eu?!" "Se for prá mim ficar assim, eu não vou querer de jeito nenhum". "Eu já tô pondo minhas barbas de molho. Se não fez prô pai vai fazer prá avó?

JP: Enquanto eu for jovem eu agradeço bastante a Deus por ter saúde.

Coordenadora: $E$ do dia de hoje o que você achou?

JP: Adorei. As colegas aqui são tudo legal. Vocês também...

Coordenadora: Como é que foi prá você Isabel? Como é que você sentiu? Liberou alguma coisa?

IC: Liberei um pouco da angústia (com os braços bem cruzados no peito).

Coordenadora: Você tava angustiada?

IC: Acho que tirei um pouco da coisa daqui (apontando para a cabeça).

Coordenadora: Você gostou?

IC: Eu adorei. Eu rezo muito prá Deus me dar forças.

Coordenadora: $E$ a OMS?

OMS: Eu adorei!

Coordenadora: A OMS estava boa hoje!

OMS (risos).

Coordenadora: A OMS tá entrando bem no papel. Todo mundo mundo é bom, tem teatralidade, mas têm pessoas que aparecem mais, outras que aparecem menos. Tem gente que demora mais prá entrar no papel, a OMS tem talento prá atriz, pois quando entra no papel, entra mesmo.

(todos concordam que ela tem talento prá atriz, tecendo alguns comentários).

IC: Tem gente que é mais timida.

NM: Eu perdi um pedacinho do começo. Eu adorei a do indio!

(todos concordam que gostaram da brincadeira do índio).

MLF: Também gostei do exercicio da bola de energia. Eu senti assim: conforme a gente mexia o corpo, parecia que as mãos mexiam sozinhas.

OMS: Senti minhas mãos quentes!

Coordenadora: E você Isabel, o que achou desses exercicios?

NM: Ela sentiu muito sono. Não parava de abrir a boca, a cada 5 minutos. Ela tá com frio agora... 
(todas elas passam as mãos pelo corpo)

Coordenadora: E o relaxamento? Vocês conseguiram sentir a "chuvinha"?

(todas concordam).

NM: $\hat{O} O \hat{O}$ (imitando o índio, batendo nos ombros da colega).

Coordenadora: Expõe a proposta de para trocar de dia (de $3^{\circ}$ para $4^{\prime}$ ) devido às aulas na Universidade (começou o semestre letivo) que seriam ministradas no mesmo dia do atendimento. $O$ grupo iria pensar e ver se conseguiria vir na 4 feira. 


\section{ANEXO 2}

- CARTA CONVITE

- TERMO DE CONSENTIMENTO LIVRE E ESCLARECIDO 


\section{Prefeitura Municipal de Ribeirão Preto \\ Estado de Sáo Paulo \\ mw.saude.rbelreopreto.sp.gov.br}

\section{CONVITE}

Vimos por meio deste convidá-la a participar cono orientadora nas aulas práticá com o grupo expressivo - teatro com os pacientes do Programa Multiprofissional en Hipertensão Arturial e Diabetes Mellitus da FUNDAP em parceria com a Secretaria Municipal de Salíle de Ribeirão Preto.

sendo só para o momento, agradecemos.

Atenciosamente,

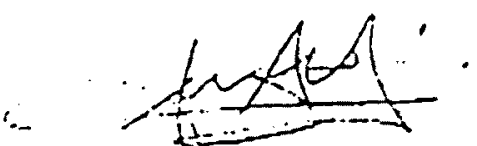

DH. LUIS ALILTU LUSI VLINA

EQUIPE TECNICA DE HIPERTENSÃOPR.OG. SAUUUE DO ADLLTO

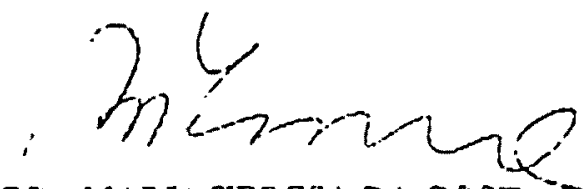

DRA MARIA TERESA DA COSTAG. TORQUATO

EQULHE LECNICA EMT DIABLTEST PROG. SAULILE DO ADULITO 


\section{SECRETARIA MUNICIPAL DA SAÚDE DE RIBEIRÃO PRETO UNIDADE BÁSICA DE SAÚDE - SIMIONI}

\section{TERMO DE CONSENTIMENTO LIVRE E ESCLARECIDO}

Nome da pesquisa: $O$ sentido do envelhecer para quem envelhece: utilizando o teatro enquanto recurso de expressão na promoção da saúde.

\section{Pesquisador responsável: Márcia Pontes Caselli CREFITO 3 - 2038 TO \\ Pesquisadores colaboradores: Lúcia Uchoa de Figueiredo, Ana Cláudia Serra Torriceli, Camila de Assis Covas}

1. Justificativa da pesquisa: Embora o processo do envelhecimento seja único e subjetivo, traz consigo conteúdos sociais, culturais, psico-emocionais e biológicos que são comuns a todos que envelhecem. A saúde aparece como um fator determinante na qualidade deste processo. A Promoção da saúde engloba ações que visam prioritariamente a prevenção, a educação em saúde e o autocuidado. $\mathrm{Na}$ atenção junto ao idoso essas ações assumem proporções quantitativa e qualitativamente importantes, uma vez que esta faixa etária (a partir de 60 anos), é a que mais cresce desde a década de 60 , e a que apresenta uma maior complexidade no campo da saúde e doença. $O$ teatro tem se mostrado um recurso terapêutico e um canal de expressão importantes, nas suas diversas manifestações, pois através do jogo dramático a pessoa pode experienciar situações e papéis de uma maneira descompromissada com as convenções e regras que direcionam o convivio social. Ele traduz e traz à luz os costumes das pessoas, recriando histórias e situações do seu cotidiano, suas necessidades, suas limitações, seus medos, sua opressão, e em troca favorece o treino de habilidades em recriar e reorientar suas ações cotidianas no sentido de resolução dos conflitos, de questionamentos pertinentes e de libertação dos entraves que dificultam sua manifestação adequada. Nesse sentido o teatro mostra-se um recurso que promove a saúde e a qualidade de vida, no seu sentido mais amplo.

2. Objetivo da pesquisa: Compreender a vivência do envelhecimento das pessoas vinculadas à Unidade Básica de Saúde Simioni, que participam dos grupos formados dentro do Programa de Promoção da Saúde da Secretaria Municipal da Saúde de Ribeirão Preto, utilizando o teatro enquanto recurso de expressão e um meio que permita a elucidação das necessidades trazidas pelos próprios idosos neste processo, a fim de apontar ações condizentes com essas reais necessidades.

3. Procedimento que será utilizado: Encontros semanais de duas horas de duração, com grupos já formados na Unidade Básica de Saúde Simioni, vivenciando técnicas de teatro e de expressão. Se autorizado pelos idosos será utilizado filmadora e/ou gravador para o registro dos encontros.

4. Desconfortos e riscos: Não esperados nesta pesquisa.

5. Benefícios do estudo: A vivência grupal e simulatória do teatro permitem que o idoso entre em contato com questões inerentes ao próprio processo de envelhecimento, e possibilite uma tomada de consciência de suas particularidades, permitindo uma reflexão e uma reformulação, se necessária, acerca do seu próprio ser-no-mundo.

Pesquisador Responsável

Pesquisador colaborador

Pesquisador colaborador

Pesquisador colaborador 
Eu,

RG ,abaixo

assinado, tendo recebido as informações sobre esta pesquisa e ciente dos meus direitos abaixo relacionados, concordo em participar.

1. A garantia de receber resposta a qualquer pergunta ou esclarecimento a qualquer dúvida acerca dos procedimentos, riscos, beneficios e outros relacionados com a pesquisa;

2. A liberdade de retirar meu consentimento a qualquer momento e deixar de participar no estudo sem que isso traga prejuizo ao andamento de minhas atividades na Unidade Básica de Saúde.

3. A segurança de que não serei identificado e que será mantido o caráter confidencial de informações relacionadas com a minha privacidade;

4. O compromisso de me proporcionar informação atualizada durante o estudo, ainda que esta possa afetar minha vontade de continuar participando;

5. O compromisso de se fazer valer a legislação em caso de dano.

Tenho ciência do exposto acima e desejo participar da pesquisa a ser desenvolvida.

Ribeirão Preto, de de 